\title{
Mudanças na educação médica: os casos de Londrina e Marília
}

Tese para obtenção de grau de doutor junto ao Departamento de Prática de Saúde Pública da Faculdade de Saúde Pública da Universidade de São Paulo, Área de Concentração Administração Hospitalar.

Orientador: Prof. Dr. Francisco B. Tancredi

Aluna: Laura Camargo Macruz Feuerwerker

Departamento de Prática de Saúde Pública

Área de concentração: Administração Hospitalar

Faculdade de Saúde Pública da Universidade de São Paulo

Maio de 2002

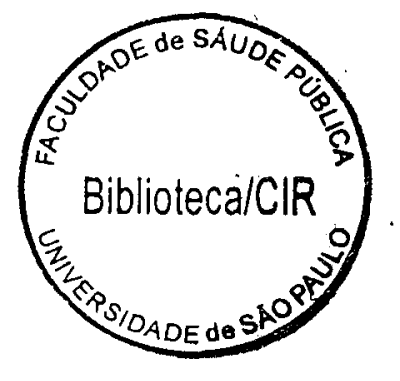


Autorizo, exclusivamente para fins acadêmicos e científicos, a reprodução total ou parcial desta tese por processos fotocopiadores.

Assinatura:

Data: 
Luz, quero luz, Sei que além das cortinas São palcos azuis $E$ infinitas cortinas Com palcos atrás Arranca, vida Estufa, veia E pulsa, pulsa, pulsa Pulsa, pulsa mais Mais, quero mais Nem que todos os barcos Recolham ao cais Que os faróis da costeira Me lancem sinais Arranca, vida Estufa, vela Me leva, leva longe Longe, leva mais 


\section{Agradecimentos}

A Marcio Almeida e Roseni Sena pelo incentivo, apoio, carinho e solidariedade sem fim.

Aos companheiros de Londrina e Marília, especialmente João Campos e Rossana Baduy (Londrina), Valeria Lima, Roseli Silva e Roberto Padilha (Marília) pela amizade, disposição, solidariedade e cooperação.

A todos os professores, estudantes, profissionais dos serviços e representantes da comunidade de Londrina e Marilia por todos os momentos compartilhados ao longo destes anos e pela cooperação para o desenvolvimento deste trabalho.

Aos companheiros da Rede UNIDA pela oportunidade de ser parte de um movimento solidário, militante e rico de experiências e formulações.

Aos companheiros dos demais projetos UNI pelo entusiasmo e generosidade ao longo de todos esses anos de trabalho e aprendizagem.

A Marco Akerman pelo interesse, carinho e apoio em momentos críticos.

À minha família, especialmente a minha mãe, ao Gui e Wladi, pela compreensão, paciência e carinho. Ao Alon pela grande amizade e pela aliança estratégica.

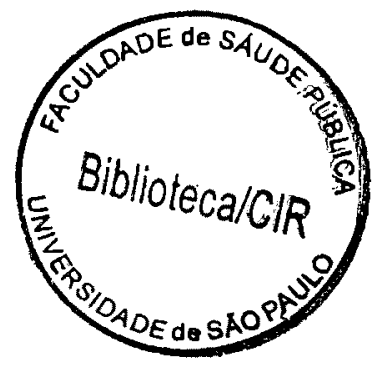




\section{Resumo}

Feuerwerker LCM. Mudanças na educação médica: os casos de Londrina e de Marília. São Paulo. 2002. Tese de Doutorado. (Doutorado em Saúde Pública Faculdade de Saúde Pública da Universidade de São Paulo).

As escolas médicas brasileiras encontram-se diante do desafio de mudar para formar profissional crítico, capaz de aprender a aprender, de trabalhar em equipe, de levar em conta a realidade social para prestar atenção humana e de qualidade. As mudanças necessárias são profundas porque implicam a transformação de concepções, práticas e de relações de poder, tanto nos espaços internos das universidades, como em suas relações com a sociedade, especialmente como os serviços de saúde e com a população. $\mathrm{O}$ objetivo deste estudo foi analisar algumas das principais causas das sucessivas histórias de resultados desfavoráveis nas tentativas de mudar a educação médica; analisar como essas questões e problemas cruciais vêm sendo tratados em dois processos de mudança na educação médica atualmente considerados promissores, quais sejam as transformações curriculares de Marília e de Londrina; e construir um conjunto de idéias, propostas e instrumentos que contribuam para a produção de mudanças efetivas na educação médica no Brasil. A metodologia adotada foi a de estudo de caso informado pelo referencial crítico-dialético. Foi feita uma análise política dos processos, assumindo o poder como categoria analítica central. Nos dois casos estudados estão em curso mudanças profundas no âmbito da organização institucional, das concepções e das práticas, bem como das relações entre professores, estudantes, profissionais dos serviços e população. Há avanços significativos, mas também problemas e conflitos, níveis diferentes de acumulação de poder técnico e político, sendo necessário um período de consolidação.

Descritores: Educação médica. Programas de ação estratégica. Mudança institucional. Articulação universidade- serviços de saúde - comunidade. Aprendizagem baseada em problemas. 
Summary

Feuerwerker LCM. Mudanças na educação médica: os casos de Londrina e Marília. (Changes in medical education: the cases of Londrina and Marília). São Paulo (BR). 2002. [Tese de Doutorado - Faculdade de Saúde Pública da Universidade de São Paulo].

Brazilian medical schools have to face the challenge of changing so as to graduate professionals capable of critical and self conducted learning, of working in teams, of taking social reality into account in the clinical practice and of delivering health attention of good quality. Deep changes will be necessary as conceptions, practices and of relations of power inside and outside the university have to be addressed. This study meant to analyze the main causes of the previous unsuccessful experiences of changes in medical education in Brazil; to analyze how the identified critical questions are being dealt in two changing processes that are taking place in Marilia and Londrina and build a set of ideals, proposals and tools that can be useful for changing medical education in Brazil. The adopted methodology was a case study orientated through the critical-dialectic reference. A political analysis was made, taking power as the central analytical category. Both of the studied cases reveal deep changes in the fields of institutional organization, conceptions and practices and relations between faculties, students, health professionals and people. Both groups present relevant results, but also problems and conflicts and different levels of technical and political power accumulation, what makes necessary a consolidation phase to take place.

Descriptors: Medical education. Programs for strategic intervention. Institutional change. University - health services - community articulation. Problem based learning. 


\section{Siglas utilizadas}

ABEM - Associação Brasileira de Educação Medica

ABEn - Associação Brasileira de Enfermagem

ABP - Aprendizagem Baseada em Problemas

ABRASCO - Associação Brasileira de Saúde Coletiva

AIS - Ações Integradas de Saúde

APS - Atenção Primária à Saúde

BIREME - Centro Latino-Americano e do Caribe de Informação em Ciências da Saúde

(antiga Biblioteca Regional de Medicina)

BNDES - Banco Nacional de Desenvolvimento Econômico e Social

CAE - Coodenadoria de Assuntos de Ensino de Graduação (UEL)

CC - Departamento de Clinica Cirúrgica (CCS - UEL)

CCB - Centro de Ciências Básicas (UEL)

CCE - Centro de Ciências Exatas (UEL)

$\mathrm{CCH}$ - Centro de Ciências Humanas (UEL)

$\mathrm{CCI}$ - Centro de Controle de Intoxicaçōes

CCS - Centro de Ciências da Saúde (UEL)

CEBES - Centro Brasileiro de Estudos sobre Saúde

CECA - Centro de Educação, Comunicação e Artes (UEL)

CESA- Centro de Ciências Econômicas e Administração (UEL)

CEPE - Comissão de Ensino e Pesquisa (UEL)

CFM - Conselho Federal de Medicina

CINAEM - Comissão Interinstitucional Nacional de Avaliação da Educação Médica

CM - Departamento de Clinica Medica (CCS - UEL)

CMB - Confederação do Médicos Brasileiros

CNRM - Comissão Nacional de Residência Médica

CNS - Conselho Nacional de Saúde

CONASEMS - Conselho Nacional de Secretários Municipais de Saúde

CONASS - Conselho Nacional dos Secretários Estaduais de Saúde

CONSUL - Conselho Popular de Saúde da Região Sul (Londrina)

COSEMS - Conselho Estadual de Secretários Municipais de Saúde

CPDC - Comissão Permanente de Desenvolvimento Curricular (CCS- UEL)

CPG - Coordenadoria de Pós-graduação (UEL)

DENEM - Direção Executiva Nacional de Estudantes de Medicina

EABP - Exercício de Avaliação Baseada em Problemas

EAC - Exercício de Avaliação Cognitiva

FAMEMA - Faculdade de Medicina de Marilia

GERUS - Desenvolvimento Gerencial de Unidades Básicas de Saúde do SUS

GIM - Grupos Interdisciplinares e Multiprofissionais (CCS - UEL)

GIT - Grupos Interdisciplinares de Trabalho (FAMEMA)

HC - Habilidades de Comunicação (FAMEMA)

HC - Hospital das Clinicas (CCS- UEL)

HIV - Human Immunodeficiency Virus

HP - Habilidades Profissionais (FAMEMA)

HU - Hospital Universitário (UEL)

IC - Interação Comunitária

IDA - Integração Docente-Assistencial 
INAMPS - Instituto Nacional de Assistência Medica e Previdência Social

INTERMED - Competição Esportiva entre Escolas Médicas de São Paulo

LDB - Lei de Diretrizes e Bases

MEB - Medicina Baseada em Evidencia

MEC - Ministério da Educação

MEQ - Modified Essay Questions

MISC - Materno-Infantil e Saúde Comunitária

MS - Ministério da Saúde

NAP - Núcleo de Apoio Pedagógico (CCS- UEL)

NESCO - Núcleo de Saúde Coletiva (UEL)

NIS - Núcleo de Informação em Saúde (UEL)

OMS - Organização Mundial da Saúde

OPS - Organização Pan-americana da Saúde

OSCE - Objective Structured Clinical Examination

PAIUB - Programa de Avaliação Institucional das Universidades Brasileiras

PALD - Patologia Aplicada, Legislação e Deontologia (CCS- UEL)

PAPIENS - Programa de Apoio a Projetos de Integração do Ensino com os Serviços de Saúde (CCS- UEL)

PAPP- Programa de Apoio a Projetos de Pesquisa (CCS-UEL)

PBL - Problem Based Learning

PEEPIN - Projeto Especial de Ensino Assistência Primaria a Saúde, Práticas

Multiprofissionais e Interdisciplinares (CCS-UEL)

PIB - Produto Interno Bruto

PIDA - Projeto de Integração Docente-Assistencial

PIMEC - Programa Integrado de Medicina e Enfermagem (FAMEMA)

PIN - Praticas Interdisciplinares em Saúde (CCS-UEL)

PMP - Patient Management Program

PROMED - Programa de Incentivos a Mudanças Curriculares nos Cursos de Medicina

PROUNI - Projeto UNI de Londrina

PSF - Programa de Saúde da Família

SEADE - Sistema Estadual de Análise de Dados

SESC - Serviços Social do Comércio

SIATE - Sistema Integrado de Atenção ao Trauma e Emergências (Londrina)

SUDS - Sistema Único e Descentralizado de Saúde

SUS - Sistema Único de Saúde

TME - Teste de Múltipla Escolha

TUFH - Towards Unity For Health

UBS - Unidade Básica de Saúde

UEL - Universidade Estadual de Londrina

UFBa - Universidade Federal da Bahia

UFPR - Universidade Federal do Paraná

UFRJ - Universidade Federal do Rio de Janeiro

UNESP - Universidade Estadual Paulista

UNI - Uma Nova Iniciativa na Educação dos Profissionais de Saúde

USF - Unidade de Saúde da Família

USP - Universidade de São Paulo

UTI - Unidade de Terapia Intensiva 


\section{Lista de Tabelas}

Tabela 1. Distribuição dos docentes envolvidos no curso de medicina da UEL segundo grau de qualificação docente e segundo Centro em 2001. Pág. 110

Tabela 2. Distribuição dos docentes envolvidos no curso de medicina da UEL segundo carga horária e Centro em 2001. Pág. 111

Tabela 3. Distribuição dos docentes que participaram do PEEPIN segundo departamentos do CCS e segundo outros Centros participantes da graduação em saúde na UEL no período de 1992 a 1996. Pág. 131

Tabela 4. Porcentagem de alunos que cursaram o PEEPIN em relação ao total de alunos da série por cursos do CCS-UEL e por anos letivos no período de 1992 a 1996. Pág. 131 


\section{Lista de figuras}

Figura 1. Pirâmide de Aprendizagem. Pág. 52

Figura 2. Características fundacionais das principais propostas de mudança da educação médica nos anos 90. Pág. 101

Figura 3 . Principais conceitos e instrumentos metodológicos concebidos pelas propostas de mudança da educação médica nos anos 90 e sua valoração. Pág. 105

Figura 4. Coeficiente de Mortalidade Infantil em Londrina de 1989 a 2000. Pág.109

Figura 5. Mortalidade Proporcional em Londrina no ano 2000. Pág. 109

Figura 6. Número de Linhas de Pesquisa por Área de Concentração desenvolvidas no curso de medicina e no CCB da UEL. Pág. 111

Figura 7. As estratégias para mudança utilizadas no componente acadêmico do Projeto UNI de Londrina de 1993 a 2000. Pág. 126

Figura 8. Esquema geral do currículo de medicina da UEL a partir de 1998. Pág. 150

Figura 9. Semana Padrão do $1^{\circ}$ ano do curso de medicina da UEL em 1998. Pág. 150

Figura 10. Estrutrura curricular do curso de medicina da UEL a partir de 1998. Pág. 153

Figura 11. O desenvolvimento dos módulos temáticos no novo curso de medicina da UEL. Pág.155

Figura 12. Evolução das práticas com e sem especifidade profissional ao longo dos módulos de práticas interdisciplinares e multiprofissionais no curso de medicina da UEL. Pág. 156

Figura 13. Desempenhos e habilidades a serem desenvolvidos ao longo do primeiro ano de medicina da UEL. Pág. 160/161

Figura 14. Possibilidades de utilização de técnicas segundo avaliação formativa ou somativa no curso de medicina da UEL. Pág. 165

Figura 15. Possibilidades de utilização de técnicas segundo áreas a serem avaliadas no curso de medicina da UEL. Pág. 165

Figura 16. Número de docente e de participações nas atividades do novo curso de medicina por departamentos e centros da UEL de 1998 a 2001. Pág. 169

Figura 17. Participação de docentes na função de tutores por departamentos do CCS ou centro nos quatro primeiros anos de implementação do novo currículo de medicina da UEL. Pág. 169

Figura 18. Capacitação de docentes segundo Departamentos do CCS e outros centros da UEL em 2001. Pág. 177

Figura 19. Participação dos docentes segundo departamentos do CCS e outros centros na coordenação dos grupos de planejamento dos módulos da $1^{\text {a }}$ à $4^{\text {a }}$ série do curso de medicina da UEL. Pág. 179 
Figura 20. Participação dos docentes segundo departamentos do CCS e outros centros da UEL nos grupos de planejamento dos módulos da $1^{\text {a }}$ à $4^{\text {a }}$ série do curso de medicina da UEL. Pág. 179

Figura 21. Árvore temática do Módulo de Concepção e Formação do Ser Humano do currículo de medicina da UEL em 1998. Pág. 180

Figura 22. Evolução da Mortalidade Infantil e seus componentes em Marília de 1980 a 2000 . Pág. 215

Figura 23. Mortalidade proporcional - Curvas de Nelson de Moraes em Marília nos anos de 1980, 1990 e 2000. Pág. 216

Figura 24. Unidades educacionais do novo curso de medicina da FAMEMA em 1997. Pág. 239

Figura 25. Semana Padrão do curso de medicina da FAMEMA em 1997. Pág.239

Figura 26. Integração básico-clínico e teoria-prática no novo curso de medicina da FAMEMA em 1997. Pág. 241

Figura 27. As dimensões da Interação Comunitária na FAMEMA em 1997. Pág. 242

Figura 28. Cronograma das atividades de avaliação no curso de medicina da FAMEMA em 1997. Pág. 257

Figura 29. Grade curricular do curso de medicina da FAMEMA em 1998. Pág. 261

Figura 30. Participação dos docentes nas atividades de capacitação de tutores segundo núcleo disciplinar de origem na FAMEMA em 1999. Pág. 262

Figura 31. Participação dos docentes segundo núcleo disciplinar de origem nas atividades do novo currículo de medicina da FAMEMA em 1999. Pág. 263

Figura 32. Distribuição dos docentes nas atividades de tutoria por série e disciplina de origem no curso de medicina da FAMEMA em 2001. Pág. 264

Figura 33. Participação dos docentes segundo núcleo disciplinar de origem no trabalho de coordenação das unidades educacionais da 1a à $4^{\mathrm{a}}$ série do curso de medicina da FAMEMA em 2001. Pág. 274

Figura 34. Participação dos docentes segundo núcleo disciplinar de origem no planejamento das unidades educacionais do curso de medicina da FAMEMA em 2001. Pág. 274

Figura 35. Distribuição percentual dos objetivos educacionais das unidades no curso de medicina da FAMEMA em 2001. Pág. 279

Figura 36. Distribuição percentual dos objetivos educacionais segundo taxonomia do domínio zognitivo nas unidades educacionais do curso de medicina da FAMEMA em 2001. Pág. 280

Figura 37. Distribuição percentual dos objetivos educacionais das unidades segundo dimensão no zurso de medicina da FAMEMA em 2001. Pág. 280

Figura 38. Distribuição percentual das questões do Exercício de Avaliação Cognitiva segundo tominio no curso médico da FAMEMA em 2001. Pág. 282 
Figura 39.Distribuição percentual das questões do Exercício de Avaliação Cognitiva segundo taxonomia do domínio cognitivo no curso de medicina da FAMEMA em 2001. Pág. 282

Figura 40.Distribuição percentual das questões do Exercício de Avaliação Cognitiva segundo dimensão no curso de medicina da FAMEMA em 2001. Pág. 283

Figura 41. Distribuição percentual das questões do Exercício de Avaliação Cognitiva segundo disciplina no curso de medicina da FAMEMA em 2001. Pág. 283

Figura 42. Distribuição percentual do conceito de satisfatório atribuído pelos estudantes às unidades educacionais na 1a série do curso de medicina da FAMEMA em 2001. Pág. 285

Figura 43. Distribuição percentual do conceito de satisfatório atribuído pelos estudantes às unidades educacionais na 2a série do curso de medicina da FAMEMA em 2001. Pág. 285

Figura 44. Distribuição percentual do conceito de satisfatório atribuído pelos estudantes às unidades educacionais na $3^{\mathrm{a}}$ série do curso de medicina da FAMEMA em 2001. Pág. 286

Figura 45. Distribuição percentual do conceito de satisfatório atribuído pelos estudantes às unidades educacionais na $4^{\text {a }}$ série do curso de medicina da FAMEMA em 2001. Pág. 286

Figura 46. Total geral de consultas e empréstimos de monografias, periódicos e audiovisuais na Biblioteca da FAMEMA de 1996 a 2001. Pág. 289

Figura 47. Distribuição percentual de conceito satisfatório atribuído pelos estudantes à unidade de Interação Comunitária da $1^{\mathrm{a}}$. à $4^{\mathrm{a}}$. série dos cursos de medicina e enfermagem na FAMEMA em 2001. Pág. 296

Figura 48. Distribuição percentual de conceito satisfatório atribuído pelos estudantes às unidades de Habilidades Profissionais em Semiologia e Comunicação da $1^{\mathrm{a}}$. à $4^{\mathrm{a}}$. série do curso de medicina na FAMEMA em 2001. Pág. 299

Figura 49. Questões para estimular a articulação das várias dimensões do processo saúde-doença no internato do curso de medicina da FAMEMA em 2002. Pág. 303

Figura 50. Principais conceitos e instrumentos metodológicos da CINAEm e do UNI na prática. Pág. 383

Figura 51. Principais estratégias de mudança da CINAEM e do UNI na prática. Pág. 384

Figura 52. Planos de profundidade das mudanças no processo de produção dos médicos. Pág. 395 
Índice

1. Introdução ...16

2. Referencial teórico-metodológico ...20

2.1. A pesquisa ...25

3. O problema: Por que não se conseguia produzir mudanças na formação médica nos últimos 30 anos? ...39

3.1. A capitalização do setor saúde e suas repercussões sobre a organização e o conteúdo da prática e da educação médicas ...31

3.1.1. A especialização ....34

3.2. A influência da corporação sobre o processo de formação dos médicos ...36

3.2.1 A Residência Médica ...37

3.2.2 O ideal de prática médica ...40

3.3. Como se construíram as tentativas de mudança dentro das escolas médicas ...43

3.3.1. A construção de sujeitos ...44

3.3.2. A ação estratégica ...45

3.3.3. As relações entre universidade, serviços de saúde e organizações

comunitárias ...46

3.4. A mudança ...47

3.4.1. O projeto político-pedagógico ...47

3.4.2 A construção do saber médico ...56

3.4.2.1 O saber médico e a ciência ...57

3.4.2.2 A incorporação de outros campos de conhecimento ao saber médico ...61

3.4.2.3 O papel da prática na construção do saber ...65

3.4.2.4. Os cenários de ensino-aprendizagem ...67

3.4.2.5 As práticas clínicas ...70

3.4.3. A avaliação ...72

3.5. O cenário político-social e econômico: condicionamentos e possibilidades de ação das iniciativas de mudança dos últimos 30 anos ...75

3.5.1. O contexto atual ...77

4. As propostas de mudança na educação médica na América Latina e no Brasil nos anos $90 \ldots 82$

4.1 Changing Medical Education: an Agenda for Action ...82

4.2. Network ...83

4.3. CINAEM ...87

4.3.1. Os UNI e a CINAEM ...94 
4.4. O Programa UNI ...96

4.5. Breve síntese comparativa das propostas ...99

5. O processo de mudança em Londrina ...107

5.1. A cidade de Londrina $\ldots 107$

5.2. O Centro de Ciências da Saúde da Universidade Estadual de Londrina .110

5.2.1. Um pouco de história ...112

5.3. O projeto UNI ...114

5.3.1 A construção da parceria do ponto de vista político ...115

5.3.2 A construção da parceria na prática ...120

5.4. O trabalho no segmento acadêmico ...124

5.4.1 A fase inicial ...124

5.4.2 Colhendo frutos ...130

5.4.3.A necessidade de novas estratégias ...138

5.4.4 Os espaços de poder ...140

5.4.5 O trabalho em outros âmbitos ...145

5.5. O novo curso de medicina da UEL ...147

5.5.1 O projeto político-pedagógico ...151

5.5.2 A concepção de currículo ...152

5.5.3 Os cenários de aprendizagem e o conteúdo das práticas ...157

5.5.4 A avaliação ...163

5.5.4.1 Avaliação do aluno: ...163

5.5.4.2 Avaliação do currículo: ...166

5.5.5. A gestão do processo de mudança ...166

5.6. O que aconteceu na prática ...168

5.6.1 O projeto político-pedagógico ...171

5.6.2 A concepção de currículo ...178

5.6.3 Os cenários de aprendizagem e o conteúdo das práticas ...185

5.6.3.1 Os PINs ...185

5.6.3.2 As práticas para o desenvolvimento de habilidades ...192

5.6.3.3 As práticas dos módulos ...194

5.6.3.4 As eletivas ...195

5.6.3.5. O Internato ...195 
5.6.4 A avaliação ...198

5.6.4.1 A avaliação dos estudantes ...198

Avaliação formativa ...199

Avaliação somativa ...201

5.6.4.2 A avaliação do currículo ...202

5.6.5. A gestão do processo de mudança ...204

5.6.5.1 A Comissão de Implantação ...204

5.6.5.2 A falta de uma direção estratégica ...207

$A$ adesão dos clínicos ...207

O trabalho de capacitação docente ...211

O trabalho de avaliação ...211

6. O processo de mudança em Marília ...213

6.1. A cidade de Marília ...213

6.2. A FAMEMA ...216

6.2.1 Um pouco de história ...217

6.3. O projeto UNI ...219

6.3.1 A construção da parceria do ponto de vista político ...220

6.3.2 A construção da parceria na prática ...225

6.4. O trabalho no segmento acadêmico ...228

6.4.1 As estratégias ...228

6.4.2. Os espaços de poder ...235

6.4.3 O trabalho em outros âmbitos ...236

6.5. O novo curso ...238

6.5.1. O projeto político-pedagógico ...243

Aprendizagem Auto-dirigida ...243

Aprendizagem Baseada em Problemas ...244

Aprendizagem Baseada em Pequenos Grupos ...246

Aprendizagem Orientada à Comunidade ...246

6.5.2 A concepção de currículo ...247

6.5.3 Os cenários de aprendizagem e os conteúdos das práticas ...250

6.5.4 $\mathrm{A}$ avaliação ...253

6.5.4.1 A avaliação do estudante ...254

6.5.4.2 A avaliação do programa ...256

6.5.4.3. Os instrumentos de avaliação ...256 
6.5.5 A gestão do processo de mudança ...257

6.6 O que aconteceu na prática ...258

6.6.1 O projeto político-pedagógico ...264

6.6.2 A concepção de currículo ...273

6.6.3 Os cenários de aprendizagem e o conteúdo das práticas ...289

6.6.3.1 A Interação Comunitária ...289

6.6.3.2. As habilidades profissionais ...297

6.6.6.3 O internato ...300

6.6.4. A Avaliação ...305

6.6.4.1 A avaliação do estudante ...306

6.6.4.2 Avaliação do programa ...308

6.6.5 A gestão do processo de mudança ...310

Os espaços de participação e decisão ...311

$O$ estilo de gestão ...314

A dinâmica do processo ...316

O cenário mais recente e os desafios para o futuro ...320

7. O trabalho dos projetos UNI na REDE UNIDA ...323

7.1. A REDE IDA

7.2. A construção da nova identidade ...325

7.3. A construção da rede como ator social buscando influir nas políticas públicas ...327

7.4 Outras linhas de trabalho em favor de um contexto mais favorável às mudanças ...330

8. Discussão ...335

8.1. Uma leitura estratégica dos processos de mudança ...335

8.1.1 O Programa UNI ...335

8.1.2. Os projetos UNI como programa de ação estratégica ...340

8.1.3. A gestão estratégica do processo de mudança no curso de medicina ..343

8.1.4. A implantação da mudança ...346

8.1.5. O mapa dos atores ...351

8.1.6. A capacidade de mobilizar e de envolver atores externos à universidade no processo de mudança no espaço local: a parceria com os serviços e com os representantes da comunidade ...354 
8.1.7. A capacidade de mobilizar e de envolver atores externos à universidade no processo de mudança no espaço global ...358

8.2. As mudanças ...361

8.2.1 O ideário UNI e as mudanças de Londrina e Marília ...361

8.2.2. O projeto político-pedagógico ...365

8.2.2 A construção do saber ....372

8.2.3. As mudanças nas relações ...379

8.3. Os projetos UNI e as outras estratégias de mudança ...380

8.4. Uma reflexão sobre o UNI em outros contextos nacionais ......388

9. Considerações finais ...391

9.1. Uma síntese provisória .....391

9.2. Um pouco mais de debate teórico-conceitual .....393

Referências Bibliográficas......400 


\section{Introdução}

Há pelo menos 30 anos, nos fóruns de discussão e reflexão sobre a educação médica, propiciados pela ABEM e por outros atores da saúde, acumulam-se os argumentos favoráveis à necessidade de mudar a educação médica. Processos de avaliação de naturezas distintas como os promovidos pela CINAEM e pelo MEC (provão e avaliação das condições de oferta) levam a conclusões semelhantes em relação ao diagnóstico de que em muitas escolas há falta de preparo dos professores para atividades de docência e de investigação, baixa produção de conhecimentos, currículos arcaicos, carga horária excessiva, dissociação teoria e prática, dissociação entre ciclo básico e clínico, formação que favorece a utilização indiscriminada de tecnologia e prática profissional impessoal e descontextualizada etc.

Pouco se tem conseguido, no entanto, em termos de resultados efetivos nas tentativas de mudança. Razões para isso? Aparentemente as forças conservadoras tiveram maior poder e capacidade de (des)articulação que as que buscavam impulsionar as transformações: muito difícil mudar estruturas tão rígidas, romper os acordos baseados no corporativismo, mobilizar professores mais ocupados com as atividades de investigação ou com sua prática profissional que com o processo de formação, impossível superar as pressões exercidas pelo mercado de trabalho sobre o processo de formação profissional (ALMEIDA,1999), (FEUERWERKER,1998).

No entanto, nos últimos anos parecem estar se acumulando problemas e elementos de contexto que favorecem as possibilidades de mudança. Problemas e elementos que dizem respeito à situação da profissão médica e seu papel social (SCHRAIBER, 1993), ao processo de acumulação capitalista em saúde, à organização do trabalho (EIBENSHUTZ, 1995), à organização da atenção à saúde (pública e privada) (MENDES, 1996), às relações médico-paciente, por um lado (MERHY, 1994) e à universidade, suas relações com os outros segmentos sociais, 
seu papel na produção, distribuição e consumo do conhecimento, na formação e educação permanente dos profissionais etc, por outro (DEMO, 1997), (SIEBENEICHLER, 1989).

Pode-se dizer que existe quase uma exigência social de que se mude o processo de formação para que se produzam médicos diferentes. Médicos com formação geral, capazes de prestar uma atenção integral e humanizada às pessoas, que trabalhem em equipe, que saibam tomar suas decisões considerando não somente a situação clínica individual, mas o contexto em que vivem os pacientes, os recursos disponíveis, as medidas mais eficazes.

Como fazê-lo é a pergunta que se colocam a ABEM e a CINAEM, que se colocam professores e estudantes das escolas médicas de todo o país, que se coloca - Ministério da Saúde diante da necessidade de incentivar a formação de profissionais adequados às necessidades de programas estratégicos como a Saúde da Família, que se colocam os gestores municipais da saúde diante da necessidade de dar respostas efetivas aos problemas de saúde da população.

Para esta investigação propus: 1) analisar algumas das principais causas das sucessivas histórias de resultados desfavoráveis nas tentativas de mudar a educação médica; 2) analisar como essas questões e problemas cruciais vêm sendo tratados em dois processos de mudança na educação médica atualmente considerados promissores, quais sejam as transformações curriculares de Marília e de Londrina; e 3) construir um conjunto de idéias, propostas e instrumentos que contribuam para a produção de mudanças efetivas na educação médica no Brasil.

Algumas objeções poderiam ser feitas a essa proposta. Primeiro, o fato de esses dois processos de mudança estarem em curso e, portanto, não ser possível fazer juízos definitivos acerca de suas qualidades ou defeitos. Especialmente considerando que muitos dos processos de mudança, atualmente considerados fracassados, resistiram alguns anos antes de serem revertidos. Como saber se o mesmo não vai ocorrer em Marília e em Londrina? 
Segundo, o fato de eu ser participante indireta desses processos por trabalhar no programa de apoio ao desenvolvimento aos projetos UNI na América Latina e ser responsável pelo acompanhamento mais próximo de sete dos 17 projetos UNI ainda vigentes, entre os quais se encontram os dois estudados.

Respondo às duas objeções de uma só vez. É verdade que processos profundos de transformação na formação são complexos, envolvem mudanças conceituais, de posturas, de lugares e de relações institucionais, envolvem o enfrentamento de conhecimentos e valores cristalizados, hegemônicos, envolvem a construção de alternativas que não estão dadas. São processos que implicam conflitos, pressões e confrontações permanentes e que estão sob risco o tempo todo. Portanto, as respostas produzidas através deste estudo não são definitivas. Mas é verdade também que a expectativa em relação à produção de caminhos mais efetivos em relação às mudanças na educação médica é muito grande. A produção de respostas, pistas, indicações, ainda que parciais, provisórias, temporárias, é muito importante e pode ser útil aos muitos outros processos de mudança que se pretende desencadear em todo o país.

Para os dois casos analisados, acredito ser também bastante útil a produção de aportes analíticos externos. Vários atores participantes diretos dos processos estão levando adiante outros estudos em que se analisam aspectos relevantes das mudanças e todos têm aportado importantes reflexões. A avaliação permanente das mudanças em seus múltiplos aspectos é fundamental para que se possam perceber problemas e limitações, corrigir rumos, fazer novas proposições ou reafirmar antigas definições.

Apesar de acompanhar os dois casos razoavelmente de perto e de contribuir, em determinados momentos, para algumas definições, considero que minha posição diante deles se define melhor como a de uma observadora participante. Participar do apoio e do acompanhamento dos processos traz como vantagem um conhecimento mais profundo das instituições, pessoas, processos e movimentos. Traz também como conseqüência, que eu tenha opiniões, prévias ao 
estudo, a respeito dos trabalhos que se desenvolvem em Marília e Londrina. Mas todos temos opiniões prévias sobre todos os assuntos. Mais ainda, olhamos para o mundo desde determinado lugar e perspectiva. Nada diferente do que ocorre neste caso entre investigadora e processos analisados. 


\section{Referencial teórico-metodológico}

Os modelos sanitários, e em particular a prática e a educação médicas em vigor em uma dada sociedade em um dado momento, estão baseados na concepção predominante nessa sociedade do que seja o processo saúde-doença. Sua especificidade é definida pelas características e pelas relações socioeconômicas, políticas e ideológicas relacionadas com o saber teórico e prático sobre saúde e doença, sobre organização, administração e avaliação dos serviços e a clientela dos serviços de saúde.

É socialmente, mediante o confronto de interesses de diversas naturezas e de diferentes segmentos sociais, que se determina o modo como se estrutura a atenção à saúde e a formação dos profissionais necessários para prestar esse tipo de serviço (MINAYO, 1992). Dentro dessa perspectiva, para este estudo é fundamental compreender em profundidade como se dão os mecanismos de determinação, de influência recíproca e as lutas de poder em torno da definição do perfil da educação médica.

Os médicos são situados como parte da força de trabalho em saúde, definida como um conjunto de agentes capazes de desenvolver ações de saúde, promoção, proteção, recuperação ou reabilitação. É fundamental entender o papel dos médicos nesse contexto, para procurar recuperar a dimensão de seu trabalho através de um conceito mais amplo de saúde, envolvendo relações com outras categorias profissionais específicas da área e com todos os agentes que de alguma maneira produzem as condições necessárias para a preservação da saúde da comunidade (PAIM, 1994).

A educação médica, entendida como processo de produção de médicos está intimamente relacionada às macroestruturas e tendências econômicas e políticas ao conceito de saúde e de necessidades de saúde (ambos historicamente definidos), à organização dos serviços e políticas de saúde e, particularmente, à prática médica. 
No entanto, existem graus de liberdade no funcionamento e comportamento das instituições formadoras, já que elas estão também condicionadas pelos confrontos dinâmicos e dialéticos entre projetos político-ideológicos de grupos sociais (PAIM, 1994). As escolas médicas, portanto, podem oscilar entre propostas e projetos transformadores ou reprodutores do modelo hegemônico, a depender do resultado das disputas que se estabeleçam em seu interior (que estão também relacionadas com forças externas, como partidos políticos, entidades da corporação, movimentos sociais etc) (ROVERE, 1996).

O indivíduo "possuído" por uma ideologia é um sujeito; a construção ideológica do sujeito é conseqüência do trabalho abstrato; é inconsciente e depende das relações sociais de produção (TESTA, 1995).

Há um processo dinâmico e dialético nos grupos e nos indivíduos que se estabelece com base na contradição marcada por privilegiar os interesses parciais (individuais ou grupais) ou os globais (coletivos, sociais) que existem sempre nos sujeitos. A resolução dessa dinâmica contraditória se dá por meio da prática, que é a que reconstrói os sujeitos que a realizam; essa resolução, que equivale a uma escolha do sujeito, é produzida em um processo dinâmico, estimulado ou dificultado pelo acontecer social global (TESTA, 1995).

A prática que concretiza a possibilidade de "reconhecer" o mundo e seus arranjos sob outra ótica, a possibilidade de conhecer outras explicações que não "as naturais" sobre porque as coisas estão como estão, funcionam como funcionam. Propicia a reflexão como prática esclarecedora, revelando opiniões, preconceitos, visões de mundo (SIEBENEICHLER, 1989). Esse é o processo de constituição de sujeitos sociais, que é um dos passos necessários para a ação transformadora.

A ação estratégica no contexto latino-americano pode contribuir para promover a criação de condições que possibilitem mudanças sócio-político e econômicas (TESTA, 1992). Mas a ação estratégica tem que levar em conta as relações de determinação e condicionamento que existem. A determinação é entendida como uma força positiva que estabelece os limites em que o fenômeno 
deve ocorrer e o condicionamento, como uma força negativa que fixa os limites fora dos quais um fenômeno não pode ocorrer.

Ainda de acordo com esse autor, há dois níveis de determinação e condicionamento em relação às ações estratégicas. Um externo, relacionado ao Estado, à História e à Teoria e outro interno relacionado aos propósitos, métodos e organizações.

Um primeiro papel do Estado, característico de seu funcionamento de conjunto (homogêneo), corresponde à garantia da continuidade do sistema capitalista e, neste caso, aos propósitos de legitimação e crescimento. Um segundo papel, corresponde à existência de contradições internas (com diferentes graus de heterogeneidade) e pode corresponder ao propósito de favorecer o desenvolvimento de conflitos. São exatamente essas contradições que a ação estratégica deve procurar explorar, de modo a facilitar situações que desencadeiem ou acelerem mudanças sociais.

Ainda nesse âmbito, o método também é determinado pela teoria do problema que procura resolver. Ou seja, é fundamental analisar profundamente o problema, pois, de acordo com a compreensão a respeito, haverá métodos diferentes e até contraditórios entre si, eficientes ou equivocados.

As organizações sofrem dupla determinação: pela história e pelo contexto. Quanto maior o peso da determinação histórica, maiores a estabilidade e o conservadorismo e mais difíceis as mudanças. Quanto maior a determinação contextual, maior a possibilidade de adaptação da organização a situações novas ou mutáveis e, portanto, mais possíveis as mudanças. As condições históricas interferem em todas essas características, definindo situações de constituição, de estabilização e de declínio, influindo diretamente sobre a maior ou menor estabilidade das organizações. O tipo de organização, portanto, condiciona o método (TESTA, 1992).

É à luz do papel do Estado, das condições históricas e do conhecimento sobre um problema que se deve construir as propostas de ação estratégica, 
definindo propósitos, métodos para alcançá-los e a organização necessária para levar o processo adiante.

No âmbito interno da ação estratégica, os propósitos determinam os métodos e a organização; o método também determina a organização. Além disso, os métodos condicionam os propósitos e ambos são condicionados pela organização. É necessário existir coerência entre propostas, métodos e organização - e esse é o Postulado de Coerência (TESTA, 1992).

O poder é uma abstração da realidade observável cotidianamente. É uma característica das sociedades opacas, gerado por e ao mesmo tempo sustentador dessa opacidade; é também a categoria que pode conduzir à explicação e à modificação dos comportamentos na sociedade (TESTA, 1995).

O poder foi utilizado como categoria central para análise da construção dos processos de mudança, que foram estudados à luz das relações entre capitalismo e saúde, prática e educação médicas e das particularidades do contexto brasileiro atual - o que é fundamental para analisar e construir viabilidade de uma ação estratégica.

Estratégia é a forma de implementação de uma política, que é uma proposta de distribuição de poder. As estratégias são fundamentais na construção de mudança porque, quando efetivas, servem para acumular poder a favor e enfraquecer o poder contra. Por essa razão foram identificadas e analisadas as alianças e estratégias desenvolvidas em cada um dos casos.

ALMEIDA (1999) estabelece distinções qualitativas em termos dos conteúdos envolvidos e dos planos em que operam os diferentes níveis de mudança que podem ser produzidos no processo de educação médica.

Num primeiro plano, o fenomênico, estão as mudanças superficiais. Geralmente pontuais, localizadas, parciais, as inovações atingem as atividades, os meios e as relações técnicas entre os agentes de ensino e o processo de ensino. Os resultados são alterações isoladas de conteúdos ou de relações ou, principalmente 
de processos. Exemplos desse primeiro tipo: criação ou ampliação da carga horária de disciplinas, projetos de extensão que estabelecem áreas de demonstração.

Num segundo plano, o dos sujeitos e atores sociais ou das relações de forças, estão as mudanças que buscam interferir em dimensões mais abrangentes do processo de produção de médicos, substituindo-as por outras que envolvem algum grau de reinterpretação das bases conceituais da educação médica. Como resultado, introduzem alterações nas relações sociais estabelecidas na formação, estabelecendo novos critérios de convivência entre os sujeitos envolvidos, incluindo aí os pacientes e a comunidade. Exemplos desse tipo de intervenções: as iniciativas de articulação entre ensino-serviços-comunidade com seus variados graus de abrangência e de profundidade.

No terceiro plano, o estrutural ou das relações sociais essenciais ao sistema de produção, ocorrem as mudanças que buscam introduzir uma nova ordem no processo de produção de médicos e nas suas relações com a estrutura socioeconômica. Ou seja, engloba o contexto e a própria sociedade e a essência do processo de produção do conhecimento, a construção de novos paradigmas e os determinantes histórico-sociais. Neste plano são as relações políticas entre os sujeitos sociais e os atores institucionais que sofrem maior impacto, resultando em alterações globais dos conteúdos, dos processos e das relações, implicando a substituição da prática médica, desenvolvimento de tecnologia apropriada, articulação biopsicossocial, intersetorialidade, superação da dissociação entre estudo e trabalho e controle social. Exemplo desse tipo de transformação: a que ocorreu em Cuba nos anos 60, com a substituição de um modelo flexneriano parcialmente implantado por um modelo de medicina social.

ALMEIDA (1999) também diz que, apesar de haver interdependências entre esses três níveis, cada um deles possui autonomias, já que os fenômenos e os atores sociais existem e se produzem constantemente dentro dos espaços sociais. Não é possível passar de um plano ao outro através de acumulações quantitativas. Para tanto, haveria a necessidade de que os atores sociais, interessados na introdução de 
mudanças mais profundas, conseguissem estabelecer novas relações de força e conseguissem imprimir projetos de intervenções mais abrangentes.

Essa proposta de planos foi utilizada para analisar a profundidade das mudanças, em termos de seus impactos em processos, relações, conteúdos etc.

Também na esfere da educação as correntes críticas identificam o papel de reprodução da cultura dominante que o sistema educacional e o processo educativo cumprem. Há segmentos, no entanto, que reconhecem existir neste campo a mesma tensão social que em qualquer outra formação social: entre as tendências de reprodução do status quo e as tendências que impulsionam a mudança e a transformação. A corrente crítico-reflexiva considera que a possibilidade de mudança e transformação da escola e do processo educativo só se concretiza na medida que outros atores, fora da escola, são incorporados ao processo educativo através da inserção da ação pedagógica na prática social. Desse modo seria possível trabalhar sobre conteúdos e relações que propiciam a reflexão crítica sobre a própria prática pedagógica e sobre a realidade social. APPLE (1995), PÉREZ GÓMEZ (1998), DEMO (1998), FREIRE (1998), BORDENAVE (1997) são autores que se inscrevem nessa perspectiva, fazendo contribuições no campo filosófico e no campo metodológico. Foi esse o referencial utilizado para analisar as mudanças no campo da educação.

As proposições de CAMPOS (1994 e 1999) e de MERHY (1994 e 1997) foram utilizadas para analisar as ações de saúde.

\subsection{A pesquisa}

Este trabalho buscou analisar os processos de mudança na educação médica desencadeados através dos projetos UNI de Marília e de Londrina. O trabalho foi feito através de um estudo de caso, informado pelo referencial crítico-dialético.

O conceito "estudo de caso" vem da tradição de pesquisa médica e psicológica, em que se refere à análise minuciosa de um caso individual que 
explica a dinâmica e a patologia de uma certa doença. Adaptado dessa tradição, o estudo de caso é uma das principais modalidades de análise das ciências sociais. (BECKER, 1997).

O caso estudado em ciências sociais é tipicamente o de uma organização ou comunidade, neste caso a escola médica. Os objetivos de trabalhos deste tipo geralmente são duplos: conhecer de maneira profunda e abrangente determinado grupo e também desenvolver declarações teóricas mais gerais sobre regularidades do processo e da estrutura sociais.

Assim postos, os objetivos do estudo de caso não podem ser completamente conscientizados, pois é utópico pretender que possa ver, descrever e descobrir a relevância teórica de tudo. Os investigadores terminam se concentrando em alguns problemas que parecem mais relevantes no grupo estudado (BECKER, 1997).

A partir de minha aproximação prévia com o tema da mudança da educação médica (dissertação de mestrado) e com os projetos de Marília e de Londrina (consultora do Programa UNI responsável pelo acompanhamento de seu desenvolvimento), fiz uma proposição inicial a respeito do que seriam as questões críticas para o sucesso dos processos de mudança da educação médica (apresentada no projeto de pesquisa).

Essa foi a referência conceitual que iluminou o processo de construção dos casos. Ou seja, houve um primeiro momento, descritivo, em que se fez a construção do objeto estudado a partir da situação concreta real, examinado-o à luz dessas questões críticas .

Para a construção dos casos foram utilizadas dados obtidos através de fontes documentais, entrevistas e grupos focais, além de material produzido ao longo do processo de acompanhamento dos projetos, que pode ser qualificado como fruto de uma observação participante.

Foram realizadas entrevistas em cada uma das instituições com as pessoas que atualmente ocupam funções-chave: os diretores das faculdades, os coordenadores de colegiado, os coordenadores de avaliação, os coordenadores de 
habilidades e os coordenadores dos módulos / unidades de interação universidade - serviços - comunidade. Os entrevistados de Londrina estão identificados no texto como entrevistado L1, L2...L5 e o de Marília estão identificados como entrevistados M1, M2...M5. Através das entrevistas foi possível explorar a percepção atual de personagens-chave acerca das características do processo de mudança, da proposta atual, das relações entre os vários sujeitos nesse processo, das estratégias utilizadas.

O roteiro básico para as entrevistas foi o seguinte:

1. Como se estão construindo as mudanças?

- O que levou a mudança a ocorrer?

- Quem participa e como participa do processo? E agora?

- Há um núcleo propulsor do processo? Como isso funcionava? Como funciona agora? Como vai funcionar no próximo período?

- Há mudanças na lógica de funcionamento da instituição em decorrência da alternativa em construção?

- Atores externos influem de algum modo no processo de mudança? Quais? Como?

2. As características da nova proposta

- Qual foi a questão central trabalhada na construção das alternativas? Por que?

- Hoje, qual ou quais as características principais da proposta de mudança? Por que?

- Como se definiram as unidades/ módulos? $E$ os problemas? Quem participa/participou?

- Como se define o trabalho dos PINs/Interação Comunitária? Quem participa/participou dessa definição?

- Quem são os tutores/instrutores das unidades?da Interação?

- Qual a relação entre teoria e prática? Como ela se dá?

- Há uma coordenação entre as várias partes do trabalho?

- Como é a avaliação dos estudantes? Quem define? Quem aplica? Para que serve?

- Existe avaliação do processo de mudança? Quem faz? Como é usada?

- Há capacitação/ educação permanente dos docentes? Como funciona?

- Há linhas de investigação? Como elas foram definidas? Há produção científica? Houve mudanças em relação ao padrão anterior? Por que?

- Quais os mais importantes desafios pela frente?

- Esta mudança já é um processo consolidado? Por que? O que fazer?

3. Algum outro aspecto relevante a destacar?

Foram realizados também, nos dois casos, três grupos focais com o objetivo de captar a percepção de um espectro mais amplo de atores e suas considerações a respeito da nova proposta. Os grupos focais com estudantes foram organizados com pelo menos um estudante de cada série. Os grupos focais com docentes foram organizados de modo a reunir docentes com o mais amplo espectro possível 
de inserções na prática do currículo e de variadas origens disciplinares e que não são dirigentes do processo, incluindo pessoas reconhecidas como de oposição (em um caso, o convidado não compareceu). Houve também um terceiro grupo focal, em cada um dos dois projetos, que reuniu professores dos outros cursos, profissionais dos serviços e representantes das comunidades, com o objetivo de captar as percepções desses outros atores em relação ao processo, já que o cenário da mudança nos dois casos vai além da escola médica.

Os grupos focais foram objeto de gravação e as fitas foram transcritas. Falas ou conteúdo de falas extraídas do material transcrito foram introduzidos no texto $\mathrm{e}$ a respectiva fonte está identificada como grupo focal de estudantes, docentes ou outros profissionais e comunidade $L$ ou $M$, quando são respectivamente de Londrina ou de Marília. Em todos os grupos focais a pergunta disparadora foi: "Qual vocês consideram ser o aspecto mais relevante do novo curso de medicina?".

Busquei utilizar o mais amplo espectro possível de fontes documentais, de modo a registrar não somente a história, mas a compreensão e a formulação que os diversos sujeitos tinham, a cada momento, em relação ao processo.

Essas fontes incluíram os projetos inicialmente apresentados à Fundação Kellogg pela UEL e pela FAMEMA para inserção no programa UNI; os relatórios de autoavaliação dos projetos UNI de Marília e de Londrina; os documentos produzidos durante o processo de preparação da mudança curricular; relatórios de oficinas de trabalho (dos projetos UNI de Marília e de Londrina e também do programa UNI); os documentos utilizados na implementação do currículo; relatórios dos fóruns de avaliação realizados em cada uma das instituições; as teses e dissertações produzidas pelos participantes dos projetos que analisam aspectos do processo de mudança; artigos de autoria dos sujeitos participantes dos projetos, documentos internos; boletins institucionais, dos projetos, das entidades estudantis e comunitárias.

No processo de construção dos casos foi caracterizada a instituição, recuperada sua situação quando do início do projeto UNI (incluindo o desenho dos 
grupos de poder e suas relações), as estratégias desenvolvidas através do projeto UNI desde o início até a aprovação da mudança. Foi apresentado o discurso sobre a mudança e depois uma reconstrução do que tem sido sua implementação prática, bem como os desafios atuais e futuros.

Aliei a reconstituição da história (sempre ilustrada com as percepções dos sujeitos ou com registros de sua autoria a respeito do processo) com a análise dos momentos que iam sendo reconstruídos. Na redação, procurei sempre deixar claro o que era a história e o que era análise da história. Também procurei construir a análise com base nas opiniões manifestadas pelos diversos atores acerca dos temas em discussão e em evidências factuais que a corroborassem.

Nos últimos cinco anos tenho sido responsável pelo acompanhamento do desenvolvimento dos projetos UNI de Londrina e de Marília, entre outros. Esse trabalho implica acompanhar o cotidiano das relações, participar como observadora (e como consultora) em determinadas atividades tais como reuniões, seminários e oficinas de trabalho, estimular a reflexão crítica sobre os processos.

Como mencionado na introdução, essa relação prévia com os processos analisados implica um conhecimento prévio relativamente profundo a respeito deles, que facilitou muito o trabalho de construção dos casos. Para evitar vieses, fiz um trabalho extenso de recuperação e apresentação do maior número possível de evidências quantitativas e qualitativas que possibilitassem uma caracterização precisa dos processos estudados. Busquei, também de forma extensa, recuperar a voz e as opiniões dos vários sujeitos participantes do processo, que estavam expressas na variedade de fontes documentais já apresentada.

Depois da construção dos casos, houve um momento exploratório, de construção do modelo teórico de investigação. Ou seja, à luz dos casos foi feita uma reconstrução dos conceitos inicialmente propostos como cruciais para a compreensão e análise das mudanças na educação médica, cujo produto é apresentado no capítulo 3. E em seguida foi elaborada a discussão, na qual se 
procurou analisar os processos estudados de acordo com categorias de análise retiradas desse corpo conceitual.

Este trabalho produziu um conhecimento, que foi produto do diálogo da pesquisadora (alguém inserido na história, que fez opções metodológicas, de interlocução e de interpretação da realidade) com os processos de mudança analisados (VIEIRA, 1991). E pretende contribuir para a construção de um projeto de mudança, falar a interlocutores reais. Não terá sido válido se permanecer intocado nas estantes da biblioteca. 


\section{O problema: por que não se conseguiu produzir mudanças efetivas na formação médica nos últimos $\mathbf{3 0}$ anos?}

Neste capítulo são apresentados e discutidos temas centrais relacionados à lógica da organização do setor saúde, ao trabalho médico, ao saber médico e à escola médica. Procura-se analisá-los e identificar sua repercussão dentro do processo de produção de médicos, a maneira como foram tratados nas iniciativas anteriores de mudança e propor como deveriam ser tratados para possibilitar um processo profundo de mudança. Está aqui apresentado o que se pretende que seja um instrumental analítico que contribui para a compreensão da contrução da mudança das escolas médicas.

\subsection{A capitalização do setor saúde e suas repercussões sobre a organização e o conteúdo da prática e da educação médicas}

A capitalização da saúde teve importantes conseqüências sobre a organização da prática médica. $O$ primeiro momento de crescimento importante do setor privado em saúde deu-se inicialmente a través da compra de serviços pelo INAMPS (BRAGA \& GOES, 1981). Nesse primeiro período, existiu também um estímulo à atividade médica especializada, através de sua remuneração diferenciada e de seu privilegiamento dentro da atividade assistencial.

Apesar de menos significativa do ponto de vista quantitativo, também houve uma ampliação da rede própria do Estado, com conseqüente aumento da oferta de empregos médicos também no setor público. Os dois movimentos, portanto, colocaram o assalariamento médico como modalidade crescente de inserção no mercado de trabalho.

Entre os anos 70 e o início dos 90, houve novamente dois tipos de movimentos na organização do setor saúde. Primeiro, a implantação do Sistema Único e Descentralizado de Saúde (SUDS) através de um processo paulatino de descentralização de recursos e de ações iniciado a partir das Ações Integradas de 
Saúde (AIS). A introdução do novo sistema levou a uma expansão do setor público e os municípios, especialmente os de porte médio, passaram a ocupar lugar relevante na criação de postos de trabalho para os médicos e para outros profissionais da saúde (MÉDICI, 1994).

Ao mesmo tempo, houve, principalmente nas regiões sul e sudeste, uma significativa expansão de sistemas de pré-pagamento, seguros-saúde e cooperativas médicas como alternativas para o acesso [individual ou coletivo] a serviços de saúde. Na década de 90 , houve novamente uma significativa expansão da rede pública, especialmente municipal, e uma consolidação da posição conquistada pela esfera privada na década anterior (MACHADO, 1997).

No primeiro movimento de expansão do setor saúde, em particular do setor privado, existiu a possibilidade de manter formas de autonomia no trabalho médico apesar do progressivo assalariamento [tanto no setor público quanto no privado]. Temporariamente, esse foi um mecanismo para garantir a sobrevivência do consultório médico individualizado.

Ao longo do tempo, entretanto, os altos custos para atualização de equipamentos, alternativas de atenção ambulatorial a custos menores e a organização da clientela em sistemas de pré-pagamento obrigaram o produtor individual a reordenar-se no sentido da coletivização do financiamento dos instrumentos, locais e outros equipamentos de trabalho, sem que necessariamente acontecesse a cooperação técnica para a produção dos serviços.

Houve também um intenso movimento de fracionamento do trabalho médico, com práticas ligadas diretamente à prestação do cuidado (profundamente diferenciadas segundo o grau de especialização) e outras de caráter mais gerencial. Passaram a existir cargas de trabalho, valorização e remuneração diferenciadas para as distintas modalidades de prática, levando a uma estratificação técnica e social no interior do trabalho médico (SCHRAIBER, 1993).

O médico perdeu seu monopólio na definição dos serviços e, ainda que continue muitas vezes produzindo seu trabalho por meio de uma prática de 
consultório, perdeu boa parte do controle sobre os instrumentos, a clientela e sobre o preço da remuneração do trabalho.

A capitalização teve também como efeito a diferenciação das instituições produtoras de serviços, dentro de certos limites técnicos - mas não éticos - segundo a lógica de suas próprias necessidades de acumulação.

A perda progressiva do controle sobre as condições de trabalho, a intermediação institucional, além da especialização, acentuaram as transformações na relação entre médicos e pacientes, ou seja, o paciente não escolhe livremente o médico que vai atendê-lo e o médico não é mais responsável pelas condições em que se dá o atendimento.

Também no mesmo sentido vão as conseqüências da incorporação tecnológica sobre a formação e sobre a relação médico-paciente. A utilização da tecnologia como elemento essencial da fase diagnóstica diminuiu, na prática, a importância da história clínica e do exame físico e, portanto, do contato do médico com o paciente e do interesse por sua fala.

Ora, conversar, escutar e examinar o paciente em sua dimensão global, ou seja, a possibilidade de aproximar-se do indivíduo como um todo era o que fazia a consulta médica individual, exclusiva e privada, ser indispensável nas práticas de atenção à saúde. Entre outros aspectos, era através dela que se realizava o aspecto humano da relação médico-paciente, incluindo-se aí compreensão, solidariedade, consolo.

Além disso, esse contato propiciava que o médico apreendesse aspectos da realidade social do paciente, indispensáveis para a produção dos "cuidados adequados" a cada nivel de extração social. A organização atual da prática desqualifica essa relação e descaracteriza a individualização que a consulta propiciaria. A quebra da relação de confiança e intimidade é um elemento concreto de ameaça ao lugar social conquistado pelos médicos e pela medicina.

Com a introdução maciça da tecnologia, o olhar médico se ampliou para além dos sintomas e agora busca alterações onde ainda não existe lesão; o olhar 
médico passa a ver o "risco", antevendo a lesão futura (SCHRAIBER,1993). Pior, na abordagem clínica de um paciente, pertencer a um grupo de risco tem o mesmo efeito de qualquer sinal clínico na prática da propedêutica: portanto o risco passou a ser objeto de diagnóstico em si (ALMEIDA FILHO, 2000).

$\mathrm{Na}$ esfera da atenção pública, houve um crescimento importante de serviços em todos os níveis, mas principalmente nos dois pólos extremos - da atenção básica e da atenção terciária. A compra de serviços de terceiros se faz essencialmente na área de recursos diagnósticos e da atenção especializada de nível secundário (as mais lucrativas).

No SUS, portanto, como houve essencialmente a reprodução do modelo hegemônico da organização do trabalho e da atenção à saúde, a ampliação da rede pública de serviços ocorreu, até a metade dos anos 90 , de acordo com a lógica imposta pela capitalização do setor saúde.

Todos esses elementos de recomposição da prática tiveram repercussão importante no processo de formação, pois foram totalmente reproduzidos dentro dos hospitais-escola, que ainda são o principal cenário de prática dos estudantes durante seu processo de formação profissional. Quase ninguém examina, nem conversa, nem se responsabiliza pelos pacientes... e esse é o modelo de prática que tem sido oferecido aos estudantes.

\subsubsection{A especialização}

Nos últimos quarenta anos teve início e adquiriu forte impulso o processo de desenvolvimento das especialidades médicas. Se do ponto de vista da produção do conhecimento a especialização propiciou, em certo sentido, um inequívoco progresso, seu impacto na organização da prática e da formação médicas foi devastador, em razão da fragmentação excessiva sobre a capacidade de intervenção prática e sobre a aquisição do conhecimento.

Talvez a medicina seja um dos campos em que as contradições da lógica cartesiana de organizar e produzir o saber fiquem mais evidentes (como diz 
Boaventura SANTOS (1996) a ciência moderna faz do cientista um ignorante especializado e do cidadão comum um ignorante generalizado).

O processo de especialização teve um forte impacto sobre a organização da prática médica. Aos poucos, foi desaparecendo o espaço para a prática do generalista e os especialistas passaram a ser a porta de entrada dos pacientes aos sistemas de saúde (público e privado). Multiplicaram-se as consultas, divididas entre os responsáveis pelo cuidado de um ou outro aparelho, e diminuiu a resolubilidade em relação aos problemas de saúde de cada pessoa.

Do ponto de vista da abordagem dos problemas de saúde, a utilização dos especialistas como porta de entrada do sistema implica em vários problemas. Sabese que para problemas comuns (que poderiam ser abordados e resolvidos por um generalista), o olhar do especialista, além de ser fragmentado e incompleto, é mais oneroso (desnecessariamente são pedidos mais exames, exames mais sofisticados, utilizam-se recursos terapêuticos mais caros e sofisticados, sem que exista diferença positiva nos resultados) - essa uma das principais justificativas para a adoção dos protocolos e das restrições à autonomia médica impostas por sistemas de controle como o "managed care".

Para a relação médico-paciente, a fragmentação da atenção implicou na não construção de vínculos (ou construção de vínculos muito fracos), na desresponsabilização dos profissionais em relação à saúde geral do paciente e em profunda insatisfação do usuário em relação à atenção que recebe.

Se os impactos dessa onda de desenvolvimento e produção de conhecimento sobre a prática médica foram tão intensos, não foram menores e nem mais controláveis suas repercussões sobre o processo de formação. Ao longo dos anos, multiplicaram-se os conteúdos especializados introduzidos durante a formação de graduação. Multiplicaram-se e fragmentaram-se tempos e disciplinas. Cada vez mais procedimentos diagnósticos ocuparam lugar do exame físico e do contato direto com paciente no processo de abordagem diagnóstica. 
Portanto, apesar de serem facilmente perceptíveis, por exemplo, os problemas que a introdução precoce das especialidades durante o processo de formação trazia, em termos de fragmentação do conhecimento, não foi possível recusar a adoção, durante a formação, da lógica que conferia ao saber e ao ato médicos um conteúdo cientificizante inédito na história.

Outra conseqüência prática desse processo foi a perda radical da terminalidade do curso médico. Em todo o país, a grande maioria dos formandos em medicina busca a especialização através dos programas de residência médica. De acordo com os dados da pesquisa "Perfil dos Médicos" (MACHADO, 1997), em 1995, 74\% dos médicos em atividade cursaram programas de Residência Médica e quase $27 \%$ dos médicos declararam haver cumprido dois programas. Por outro lado, $40 \%$ referiram curso de especialização após a formatura. No cômputo final, entre residências concluídas e exames prestados, $59 \%$ dos médicos brasileiros possuiam título de especialista.

\subsection{A influência da corporação sobre o processo de formação dos médicos}

Sempre houve, ao longo desses quarenta anos, a percepção de que forças e interesses externos influíam nos processos internos das escolas, especialmente na definição do perfil do profissional a ser formado.

Se o mercado valoriza o trabalho dos especialistas, há uma tendência a orientar a formação para essa direção e o principal impacto da tendência à especialização sobre a graduação é a fragmentação dos conhecimentos e a perda de terminalidade.

Cabe destacar, no entanto, que a influência conformadora do mercado tem sido muito marcante no terreno da pós-graduação, estimulando a especialização através da Residência Médica. 


\subsubsection{A Residência Médica}

A Residência Médica existe no Brasil desde a década de 40. Até a metade da década de 50 os programas atingiam apenas uma parte muito pequena dos egressos das escolas médicas. Nos dez anos seguintes foi havendo uma ampliação gradual do número de programas, num processo de consolidação da Residência Médica como modalidade de especialização dos profissionais médicos em todas as regiões do país. (BRASIL, 1989).

Naquele período o perfil do profissional a ser absorvido pelo mercado começou a mudar em razão de inúmeros fatores: o desenvolvimento tecnológico e da área de equipamentos, a adoção do modelo de atenção baseado na utilização intensiva [e progressiva] de tecnologia e na especialização do médico e a conseqüente reorganização do trabalho e do mercado de trabalho médico.

Por outro lado, houve uma importante ampliação do número de vagas nas escolas médicas, que não foi acompanhada de medidas para reorganizar o mercado de trabalho médico, ou seja, para enfrentar a desigualdade da distribuição desse profissional. A criação de postos de trabalho, portanto, continuou seguindo a mesma lógica de concentração nos locais de maior riqueza. A concentração de empregos nas grandes cidades fez com que aumentasse substancialmente a competição pelas melhores colocações no mercado.

A insuficiência do treinamento prático proporcionado pelas faculdades de medicina (em razão do processo de fragmentação que a formação de graduação vinha sofrendo) e a existência de um mercado de trabalho mais competitivo e voltado à especialização, portanto, foram os ingredientes essenciais à multiplicação da procura por vagas de Residência Médica pelos recém-formados.

Assim, houve um processo de ampliação do número de vagas nas instituições já comprometidas com a Residência e, além disso, muitas instituições hospitalares, ligadas ou não a escolas médicas e universidades, passaram a oferecer programas de especialização. $\mathrm{Na}$ verdade, como não existia qualquer 
regulamentação em relação aos programas de residência, eram oferecidas aos médicos recém-formados oportunidades de trabalhar nos hospitais, supostamente sob supervisão, a baixa remuneração (SOUZA, 1985; ROCHA, 1983; BRASIL, 1977).

Mesmo depois da criação da CNRM e da regulamentação da residência (1979), como a demanda por mais vagas era um fenômeno real e os residentes cumpriam um papel importante na prestação de serviços e na introdução de um patamar mínimo de tecnologia ao nivel das instituições, houve um novo fenômeno de expansão de vagas. Em 1982 havia 1.500 vagas de residentes de $1^{\circ}$ ano e em 1984 essas vagas já eram 4.097. Ou seja, já nessa ocasião, quase $51 \%$ dos médicos graduados tinham a oportunidade de ingressar em programas de Residência Médica (SOUZA, 1985).

Esse movimento de expansão persiste até os dias atuais: no período de 1985 a 1996, existiu um crescimento de $51 \%$ no número de instituições credenciadas. O número de vagas para R1 aumentou de 3.983 para 6.124 (FUNDAP, 1999). Os governos estaduais, geralmente através das secretarias estaduais de saúde, são os principais financiadores de bolsas (quase $50 \%$ delas), seguidos pelo MEC e pelas instituições privadas.

Mesmo com as tendências de reorganização das práticas sanitárias, com uma revalorização da formação geral e maior ênfase em promoção e prevenção, as vagas para Residência Médica continuam em expansão.

Razões para essa contradição existem desde a regulamentação da residência (ELIAS, 1987), definida como modalidade de pós-graduação sensu lato. Nessa época, foi criada a Comissão Nacional de Residência Médica, que ficou localizada no MEC. No entanto, a composição da Comissão sempre contemplou fundamentalmente a representação das entidades da corporação médica.

Essa composição da CNRM levou a que o pensamento organizado sobre a Residência Médica operasse essencialmente no âmbito dos interesses da 
corporação médica, desvinculando a Residência das necessidades e da lógica tanto do processo de formação, como da organização dos serviços de saúde.

Como conseqüência, a CNRM sempre funcionou num mundo à parte, sem força política para pautar a Residência Médica nas políticas de saúde ou nas de educação. Por outro lado, isso possibilitou o crescimento quase ininterrupto das vagas de Residência Médica no país e, ultimamente, a ampliação do tempo de duração dos programas. Por outro lado, implicou a limitação dos necessários meios e da força política para mobilizar recursos, por exemplo, para assegurar qualidade aos programas.

Mesmo que hoje houvesse uma mudança na composição da Comissão, como sugerem atualmente setores do MEC e do Ministério da Saúde, como não há políticas claras em relação à formação de profissionais de saúde, não haveria elementos suficientes para reorientar de imediato a atuação da CNRM.

É preciso saber quantos e que especialistas são necessários ao sistema de saúde. É preciso estabelecer mecanismos de compensação entre as regiões para compensar os desequilíbrios na oferta de programas e de especialidades. É preciso articular as decisões políticas envolvendo a organização do sistema de saúde com as decisões políticas em relação à formação dos recursos humanos.

Para haver coerência com as novas tendências de organização da prática, será necessário fazer não somente a revisão do número de programas e de vagas, mas também redefinir conteúdo e cenários de formação.

Propostas de mudança na educação médica sem estar articuladas com mudanças no papel e na estrutura da Residência Médica perderão muito de sua potência e impacto. Portanto, será importante repensar a formação médica como um todo, incluindo aí as mudanças na Residência Médica (FEUERWERKER, 1998). 


\subsubsection{O ideal de prática médica}

Como já mencionado, há pressões das mais variadas naturezas no sentido de que ocorram mudanças na formação médica. Continua, entretanto, muito forte, dentro das escolas, a resistência às mudanças. Especialmente se implicam sair do hospital, trabalhar em outros cenários e em reorientar a formação em direção a um perfil mais geral.

Aparentemente os médicos resistem a se aproximar dos cenários que se distanciam do ideal de prática que cultivam: especialista com alguma inserção prática em um hospital privado de alto nível e com prática "liberal" em um consultório privado. A este ideal corresponde como cenário de práticas ideal o hospital e outros equipamentos que permitam acesso às tecnologias. $O$ outro caminho está associado à ocupação de postos de trabalho que quase ninguém quer: o "médico de posto", o plantonista da emergência nos pronto-atendimentos e hospitais da periferia.

Atualmente $70 \%$ dos médicos mantêm atividades no setor público e somente $28 \%$ trabalham exclusivamente no setor privado; $24,6 \%$ dos médicos não têm prática de consultório e $75,6 \%$ associa até três atividades de trabalho. Para os mais jovens uma das atividades mais freqüentes é o plantão e muitos dos especialistas trabalham fora de sua área de especialização (MACHADO, 1997).

No entanto, saber das condições do mercadi de trabalho e das situações da prática não muda a expectativa dos médicos em relação ao seu ideal de prática. Esse ideal está muito ligado a uma imagem da profissão extraída dos valores tradicionais e de identidades profissionais bem sucedidas no passado (SCHRAIBER, 2000).

Esse imaginário e as expectativas que os médicos trazem para o exercício da prática são tão fortes, que, diante das condições de trabalho distantes do esperado, cada médico faz uma adaptação possível, buscando resgatar ou manter algo daquelas expectativas (SCHRAIBER, 2000). 
Mudaram os valores dos médicos em relação a vários aspectos da prática: a UTI, a precisão tecnológica, a especialização, a impessoalidade nas relações, o jogo das instituições, a recusa à vida de sacrifícios, a comercialização do trabalho médico são parte de um novo tempo e de um novo lugar social da profissão.

Isso contribui para que um contingente expressivo dos médicos busque defender-se das condições adversas da prática profissional comprometendo a qualidade dos serviços prestados à população. Resiste, por exemplo, a mecanismos de controle da freqüência no setor público (inclusive nos hospitais universitários); não cumpre a carga horária de trabalho para manter dois empregos praticamente no mesmo horário; brinda atenção clínica diferenciada de acordo com o poder de compra dos pacientes - "convênio ou particular".

Por outro lado, a categoria não é homogênea, há médicos éticos e não éticos, há contradições entre médicos empresários e médicos assalariados. No entanto, mesmo as entidades sindicais têm adotado posturas de defesa dos interesses dos médicos por vezes contraditórias com os interesses da maioria da população. $\mathrm{E}$ os dirigentes de muitas das outras entidades médicas fazem parte da fração da categoria que conseguiu manter a prática liberal ou que teve êxitos na medicina empresarial.

A hipótese então, é que as relações hegemônicas de poder dentro da categoria, a manutenção de uma imagem de ideal profissional vinculada à prática privada e liberal e a legitimação acrítica de práticas indefensáveis de acordo com os preceitos da ética são a base de uma boa parte da resistência da categoria às mudanças na formação profissional dentro e fora das escolas.

Quer dizer, então, que o mercado exerce uma influência importante sobre a conformação do perfil profissional, mas a corporação exerce também um papel fundamental, especialmente dentro das escolas. E aqui no Brasil, pelas circunstâncias já comentadas, também na configuração do restante do processo de formação, especialmente a Residência. 
Para mudar o processo de formação de graduação, portanto, seria necessário enfrentar, dentro das escolas, essas contradições da categoria médica. Construir uma nova postura ética e um novo ideal profissional e transformar a prática dos profissionais que estão envolvidos com a educação dos estudantes são parte dessa tarefa.

"Ser muito ocupado e ser empreendedor; conhecer as engrenagens do mercado $e$ reconquistar os pacientes e uma clientela sua; empresariar-se e manter-se ético; desenvolver raciocinio crítico diante da acelerada produção de novidades e das tecnologias; ser científico, dominando a arte da profissão" são alguns dos impasses que a categoria tem que enfrentar para construir um outro modelo de prática e de profissão (SCHRAIBER, 2000).

Mostrar aos médicos que as propostas de mudanças ajudam a encontrar respostas para uma parte desses desafios deve ser parte das estratégias dentro da construção dos movimentos dentro das escolas.

Ajudar os médicos (ou parte deles) a perceber que a possibilidade de conquistar melhores condições de trabalho, remuneração e prática profissional dignas não será conquistada se a categoria continuar defendendo seus interesses imediatos acima de quaisquer outros, isolando-se de setores da população, que poderiam ser seus aliados.

Sem dúvida isso não se fará sem ajudas externas: sociedades de bioética, as organizações da população, os gestores dos serviços de saúde certamente serão aliados nesse trabalho.

A coerência entre discurso (de mudança) e prática (diante das posturas contraditórias da categoria) parece ser fundamental para dar consistência a uma proposta de mudança. 


\subsection{Como se construíram as tentativas de mudança dentro das escolas médicas}

Esta parece ser uma questão decisiva. São inúmeros, incontáveis, as tentativas de mudança que partiram de idéias interessantes e bem formuladas, que, no entanto, não conseguiram nunca sair da gaveta. Há alguns problemas "clássicos" nesse terreno (FEUERWERKER,1999c).

O primeiro deles é trabalhar uma proposta de mudança que tem "proprietários". Esse é um tema relacionado à construção de viabilidade de uma proposta de mudança. Em muitos casos do passado, foi quase uma "tentação irresistível" trabalhar quase exclusivamente com as pessoas que já estavam ganhas para a idéia de mudar, que pensavam de maneira parecida ou que se mobilizavam mais em torno do tema. As discussões evoluíam mais facilmente, os consensos se construíam mais rapidamente... mas a chance de esses planos saírem do papel e se tornarem realidade foi sempre muito pequena. Foi o caso de muitas das experiências de integração docente-assistencial.

O segundo problema foi trabalhar a proposta de mudança a partir da iniciativa de grupos não relacionados diretamente com o poder. Para ser efetiva, a decisão de mudar deve ser institucional. Quer dizer que a proposta de mudar deve entrar pela porta da frente, deve ser compromisso do núcleo central de poder, ou seja, da direção. Isso torna possível que se utilize, pelo menos em parte, os recursos de poder que a direção da escola, curso ou centro disponha para viabilizar a mudança. Isso é importante para aumentar as chances de acesso e mobilização dos professores, para minimizar o peso de determinados entraves burocráticos, para quebrar as barreiras impostas pelos nichos de poder estabelecidos etc. Portanto uma das tarefas dos grupos "mudancistas" dentro das escolas é chegar ao poder direta ou indiretamente. De fora do poder, a mudança ou não se estabelece ou perde força ao longo do tempo, como aconteceu com o curso Experimental de Medicina na Faculdade de Medicina da USP e com a experiência da UNB (neste 
último caso, o poder dentro da faculdade foi perdido através ação externa da ditadura).

A viabilidade das propostas de transformação das escolas médicas, portanto, depende da capacidade de criar "massa crítica" e do grau de "governabilidade" dos sujeitos proponentes da mudança. Sem isso a mudança não se viabiliza na prática, mesmo que consiga ser formalmente aprovada. Esses temas, no entanto, não se constituíram em objeto de preocupação específica dos grupos que conduziram propostas de mudança da escola médica no passado.

\subsubsection{A construção de sujeitos}

A transformação das escolas médicas implica a mudança de relações de poder - dentro da escola, entre departamentos, entre professores e alunos e também na relação com outros segmentos da sociedade; implica a busca da superação do paradigma positivista na produção do conhecimento, na construção do saber médico e na concepção do processo saúde-doença.

A base dessa proposta de mudança é a democratização, um produto social que se constrói através da intervenção deliberada de sujeitos e que depende da correlação de forças, da mudança dos poderes instituídos, da capacidade de se construírem espaços de poder compartilhado.

A mudança institucional, portanto, começa já no próprio processo de construção da proposta de transformação, que deve ser feita através da criação de espaços coletivos, possibilitando a participação do maior número possível de professores e alunos, do maior número possivel de áreas e departamentos (CAMPOS, 2000).

Segundo MATUS (1996),

"os atores sociais são os únicos produtores coletivos de eventos sociais e, em conseqüência, são os sujeitos da mudança situacional. Esses atores podem 
seguir um processo de produção direta utilizando o poder que têm em si ou um processo de produção indireta através das instituições que controlam".

Estudantes e professores têm que ser sujeitos desse processo de mudança. Esses sujeitos se constituem no processo coletivo de reflexão crítica sobre as práticas tradicionais, de aquisição de novos conhecimentos e de novos poderes que diminuam as distâncias entre dirigentes e dirigidos.

Por essa mesma razão, as transformações não são definições a priori. Não é possível impor aos coletivos das escolas um ou outro modelo, uma ou outra proposta. Deve-se discutir princípios, conceitos, mas as alternativas vão ser construídas dentro de cada escola. Elas se constroem no cotidiano da prática pedagógica e não simplesmente no papel; na prática clínica concreta e não somente "em laboratório" ou "ambientes especiais", em todos os cenários onde se dá a prática profissional e enfrentando os problemas que se apresentam na realidade.

O projeto de transformação maior e mais profunda da formação profissional se constrói também através do conhecimento e da força que se acumula através das pequenas inovações e da reflexão crítica sobre o cotidiano e sobre as novas experiências desenvolvidas (DEMO, 1998).

Assim, é fundamental que sejam oferecidas oportunidades para que muitos professores se envolvam/proponham/construam múltiplas experiências inovadoras nos mais variados cenários. O foco da ação deve estar centrado no investimento nas pessoas, enquanto potencialidade para um novo processo de formação dos profissionais de saúde.

\subsubsection{A ação estratégica}

A mudança tem que ser construída com base na participação ampla e tem que ser conduzida por um grupo que saiba ser estratégico. Na construção da possibilidade de mudar, no próprio processo de mudança e em sua consolidação, é 
preciso ativamente acumular poder a favor e diminuir a capacidade de ação das forças contrárias.

É importante saber que consenso não é unanimidade, não é um fenômeno espontâneo, portanto tem que ser ativamente construído. Também é importante saber que processos de mudança não são estáticos, ao contrário: quem está de um lado hoje pode estar do outro amanhã.

O planejamento estratégico e o esforço organizado de construir canais de comunicação e discussão coletiva são parte dos instrumentos essenciais para a condução dos processos de mudança.

Tudo isso dá trabalho, leva tempo, consome muita energia. Mas não há mudança profunda que ocorra sem isso.

É fundamental também saber buscar aliados fora do espaço da escola: os serviços de saúde e as organizações comunitárias podem ser aliados importantes na legitimação de determinadas propostas, na explicitação de determinados problemas. É o tema que discutimos a seguir.

\subsubsection{As relações entre universidade, serviços de saúde e organizações comunitárias}

A participação de atores externos à comunidade interna da universidade (ou da escola médica) e à corporação (médica) nos movimentos de mudança cumpre um papel, essencial. Na verdade, como já vimos, "forças externas" às escolas atuam de maneira muito forte, através dos interesses corporativos e de interesses econômicos de natureza variada. Esses interesses foram estruturantes em relação à conformação dos arranjos de poder dentro das instituições universitárias.

Abrir espaços para os atores representantes dos interesses dos serviços públicos e da população significa abrir espaço para que "o outro lado" também possa influir de maneira ativa nas disputas que se travam dentro das escolas 
médicas. Serve para que as forças progressistas de cada segmento possam se potencializar mutuamente (ALMEIDA, 1999).

Como pré-requisito básico para essa interação, tem sido indispensável construir parcerias, ou seja, mecanismos de co-gestão do processo de ensinoaprendizagem e de produção da saúde entre Universidade, Serviços de Saúde e Comunidades.

À diferença de experiências anteriores de relações das universidades com os serviços (IDA), essas são relações mais horizontais em que o processo de trabalho é realmente conjunto, levando em conta os interesses, necessidades e potencialidades dos outros dois parceiros.

Já que nos processos de mudança estão sempre presentes quatro movimentos fundamentais: participação, conflito, poder e cooperação, o estabelecimento de relações horizontalizadas entre universidades, serviços de saúde e comunidades objetivava criar espaços reais de troca, interlocução e transformação mútua. Busca-se estabelecer uma base mais favorável para o enfrentamento dos conflitos que inevitavelmente surgem no percurso.

Universidade, serviços e comunidades não são todos homogêneos. Ao contrário, em verdade, no interior de cada um deles há grupos com interesses distintos, que jogam papéis variados. É fundamental reconhecer essa heterogeneidade e preparar-se estrategicamente para lidar com ela. Além do mais, existe uma importante assimetria de poder entre esses parceiros. Por isso, é importante haver uma disposição prévia a um acordo, porque os conflitos para determinar o rumo a ser seguido são intensos.

\subsection{A mudança}

\subsubsection{O projeto político-pedagógico}

É amplamente reconhecido, que não existe nas escolas médicas um preparo específico para os professores no terreno pedagógico. A competência na área 
técnica de atuação médica tem sido o critério fundamental para a seleção ou eleição dos que vão passar de médicos a pesquisadores e professores. Isso implica a existência de um profundo desconhecimento de técnicas e metodologias de ensino, de trabalho com grupos e de produção de materiais didáticos apropriados.

Mais grave ainda que não haver formação técnica específica no terreno pedagógico, é o fato de predominar amplamente nas escolas médicas uma concepção tradicional de ensino, segundo a qual a educação está baseada na transmissão do conhecimento e na experiência do professor, na supervalorização do conteúdo da matéria e na expectativa de que aluno o absorva e reproduza os conteúdos (BORDENAVE \& PEREIRA, 1998).

Na verdade, o problema é ainda mais complexo. Se entendermos que os currículos são a expressão do equilíbrio de interesses e forças que operam no sistema educativo em dado momento; se soubermos que os currículos estão relacionados com a questão do poder e transmitem visões específicas sobre a sociedade e seus valores, vamos perceber que esse debate nas escolas médicas foi sempre feito de maneira muito limitada.

Os currículos expressam o modo como uma instituição educacional se vê no mundo, ou seja, qual o seu papel, que relações ela deve estabelecer, quem são seus interlocutores, como se concebe o conhecimento (como ele é produzido, para que serve), como se concebe a educação, qual o melhor jeito de aprender, como a escola se organiza considerando os elementos anteriores, o papel (e o poder) que cada um tem dentro da escola. No caso de uma escola de medicina, o currículo também expressa a concepção que se tem sobre saúde, sobre o papel do médico na sociedade, sobre o médico que se quer formar etc.

Nas escolas médicas em geral - e na maior parte das propostas de mudança que existiram até aqui - no máximo se discutia o papel da escola e o perfil do médico. A concepção de saúde muitas vezes estava implícita. Assim como a concepção de conhecimento, educação etc. E o currículo era organizado através de uma sucessão de disciplinas, cuja ordenação definia o percurso do estudante no 
processo de ensino - aprendizagem. As disciplinas são a expressão da cultura elaborada, que deve ser transmitida pelo professor ao aluno e é através delas, supondo-se determinados conteúdos educacionais, que se define o conhecimento avaliável. Pois bem, essa é a modalidade de currículo mais tradicional que existe... e surgiu na Idade Média... (SACRISTÁN, 2000).

Além do mais, os processos de mudanças curriculares sempre envolveram disputas ferozes e negociações complicadas porque a definição das cargas horárias das disciplinas refletia o jogo de poder entre departamentos e professores: a carga horária tinha menos a ver com a relevância do conteúdo e mais com o poder dos mestres. Alguns processos de inovação curricular (modesta) chegaram a levar 10 anos!!

Por conta disso, geralmente se leva muito tempo para retomar a batalha e iniciar um outro processo de reformulação curricular...Enquanto isso, as ementas se repetem ano a ano, os slides, as transparências. Nas escolas mais dinâmicas, novas disciplinas ou novos conteúdos são introduzidos, dependendo do avanço da descobertas ou do reconhecimento de que determinados temas candentes (os problemas éticos que surgem com a nova maneira de trabalhar dos médicos ou com os avanços da genética, por exemplo).

Num mundo em que a produção de conhecimentos adquiriu uma velocidade vertiginosa realmente esse modo de pensar o currículo ficou totalmente obsoleto. A flexibilidade, a possibilidade de mudar freqüentemente dependendo dos resultados e do que vai acontecendo no mundo é fundamental. A ênfase nos conteúdos também é insustentável: é impossível cobrir tudo e é impossível atualizar tudo em tempo real. Pela via da necessidade de continuar aprendendo toda a vida, já se consegue convencer os professores de que o estudante, mais que receber toneladas de informações, precisa aprender o essencial e, mais que tudo, aprender a aprender criticamente.

Mas qual o melhor jeito de aprender e de aprender a aprender? Durante os últimos trinta anos quando se tratou da questão pedagógica dentro da educação 
médica no Brasil, houve maior ênfase no desenvolvimento de materiais didáticos e na incorporação de determinadas técnicas pedagógicas, do que uma análise crítica sobre as concepções pedagógicas predominantes nas escolas médicas ou a incorporação dos conceitos atuais para a educação de adultos. Não houve, tampouco, um investimento na formação pedagógica dos professores. Predominaram, portanto, ações instrumentais de baixo impacto.

As universidades latino-americanas em geral e as escolas médicas em particular são instituições muito tradicionais. No processo de formação dos médicos tradicionalmente estabelecem-se relações hierárquicas bastante estruturadas em que o mestre (o profissional mais experiente) orienta a prática e o aprendizado dos discípulos, (que, para garantirem o direito de receber tais conhecimentos, são encarregados de desempenhar todas as tarefas menos nobres). Os discípulos, por ordem de antigüidade, vão, progressivamente, conquistando o direito de participar da execução de tarefas de maior complexidade e responsabilidade (e prazer e poder) (FEUERWERKER, 1998).

Esses métodos e relações são muito semelhantes aos existentes nas corporações de ofício na Idade Média (mais uma vez...). No entanto, essa ainda é a base fundamental da organização do treinamento prático dos médicos, tanto no internato como na residência. A hierarquia e os rituais do poder são, portanto, extremamente valorizados dentro da categoria médica e também dentro das escolas. Mais uma vez, portanto, as relações de poder dentro da categoria influenciam fortemente as relações e as concepções dentro da escola médica.

Para poder mudar, as escolas vão ter que enfrentar esse problema, pois, de acordo com várias teorias pedagógicas, a melhor maneira de aprender é sendo sujeito da aprendizagem e não receptor de informações. Ser sujeito da aprendizagem quer dizer que a pessoa que está aprendendo vai, ela mesma, ativamente, buscar os conhecimentos necessários para dar resposta a uma pergunta, a um problema, a uma situação. Daí a necessidade ou a oportunidade das metodologias ativas de ensino-aprendizagem tanto para crianças $e$ 
adolescentes, como para adultos (PIAGET, 1988); (DEWEY, 1971); (ROGERS, 1978);(FERREIRO \& TEBEROSKY, 1985); (FREIRE, 1975).

Dependendo da concepção pedagógica, as perguntas, situações ou problemas que vão ser usados para provocar a aprendizagem são definidos segundo critérios diferentes: de acordo com os objetivos educacionais que se pretende atingir, baseado nas necessidades de aprendizagem dos estudantes, baseado em um problema real que existe na sociedade, por exemplo. Pelos mesmos critérios, define-se também o papel do professor: facilitador do processo de busca do estudante, encarregado de estimular, responsável por armar os dispositivos iniciais, estabelecer uma relação dialógica; assim também se definem o papel e as metodologias de avaliação. Dependendo da metodologia pedagógica adotada, há maiores ou menores possibilidades de o estudante desenvolver a iniciativa, o espírito crítico, o conhecimento da realidade, o compromisso social (GADOTTI, 1998).

Já se fizeram muitos estudos para tentar medir quanto pessoas aprendem (internalizam, apropriam-se) e quanto as pessoas lembram, dependendo da situação de aprendizagem de que participaram. A figura 1 é ilustrativa: 
Figura 1. Pirâmide de Aprendizagem

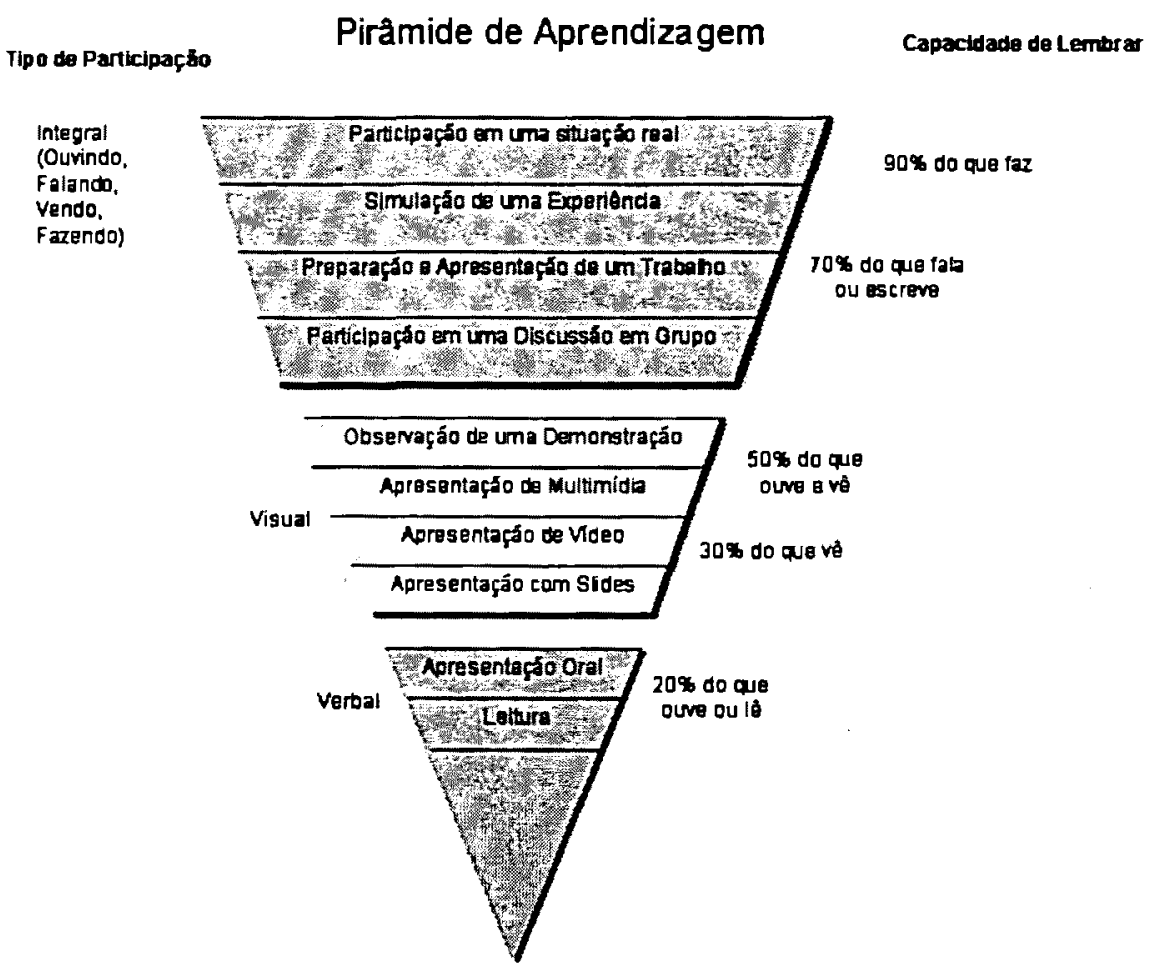

Fonte: Módulo de Capacitação Docente: des-construindo as unidades educacionais. FAMEMA, 2001.

Como se vê, a prática é fundamental no processo de aprendizagem, mas dependendo também da concepção pedagógica, existe maior ou menor articulação da situação de aprendizagem com a prática e com a produção de conhecimento.

Cada concepção pedagógica propõe também modos diferentes de pensar e organizar o currículo. Sobre o currículo tradicional, já falamos, organiza-se em torno de disciplinas. Mesmo segundo essa concepção, há possibilidades de organização que facilitam a integração dos conteúdos. Há um padrão unificado, clássico, segundo o qual o mesmo assunto é estudado sob vários pontos de vista. No padrão integrado, as habilidades aprendidas numa disciplina são usadas como ferramenta em outras. No padrão correlato, as disciplinas mantêm suas identidades, mas os estudantes aprendem como os conceitos de uma se 
relacionam com os de outra. No padrão de solução de problemas complexos, cada disciplina visa o desenvolvimento de um conceito ou método (MCNEIL, 1989a).

Uma segunda possibilidade é organizar o currículo através de objetivos de aprendizagem, que implicam o desenvolvimento de atitudes, habilidades e conhecimentos, que são atingidos através de estímulos educacionais apropriados. Os objetivos instrucionais de cada disciplina são organizados num continuum ou numa hierarquia fixa de habilidades. A base conceitual dessa proposta é a psicologia comportamental e ela está centrada no aprender a fazer e na lógica estímulo/compensação/ punição (SACRISTÁN, 2000).

Outra possibilidade que existe é organizar o currículo de acordo com as necessidades de aprendizagem dos estudantes. São, portanto, propostos uma multiplicidade de meios e situações com o objetivo de oferecer ao estudante as mais variadas oportunidades de aprendizagem. Ou seja, parte-se de uma determinada organização de conteúdos, que articulam as disciplinas de maneira integrada, e de ofertas de experiências práticas e, de acordo com as necessidades de ensino-aprendizagem (individuais e coletivas), há flexibilização e reformulação da proposta original. As concepções da Escola Nova dão a base para esta proposição (GADOTTI, 1998) (MCNEIL, 1989b).

Uma outra possibilidade, chamada currículo de construção social, organiza as atividades de aprendizagem em torno de questões cruciais, como poderiam ser as necessidades ou os problemas de saúde da população, que também deve participar como ator ativo do processo educacional. O conhecimento é produzido a partir do desafio de enfrentar os problemas vividos na realidade social e as soluções construídas devem ser levadas à prática, possibilitando a produção de novos conhecimentos. Nesta proposta também não cabem disciplinas e se faz a integração do ensino, da pesquisa e da prestação de serviços através do trabalho em torno dos problemas reais. A base fundamental desta proposição é a pedagogia crítica (MCNEIL,1989c) (YOUNG, 1991). 
Como os currículos expressam, entre outras coisas, as relações de poder, é comum que os processos de mudança levem à produção de propostas híbridas, que combinam aspectos parciais de várias proposições político-pedagógicas. Muitas vezes não há como escapar dessa situação, mas é importante saber dos riscos envolvidos: pode-se criar situações e orientações muito contraditórias (às vezes antagônicas) que confundem o estudante e prejudicam a aprendizagem; pode-se a adaptar uma proposta a tal ponto que ela se desconfigura, perde completamente a potência e se desmoraliza; pode-se pensar que está fazendo uma coisa e na verdade está-se fazendo outra muito diferente.

Normalmente existe mesmo uma diferença entre o que se pretende fazer e o que se faz na prática, tanto que há uma proposta que defende que se entenda o currículo como um processo: parte-se do currículo prescrito (que é o que foi aprovado, que expressa os princípios) para o currículo planejado (que está plasmado nos manuais, guias, ementas) e para o organizado (recursos educacionais, infraestrutura, apoio administrativo), que se concretizam no Currículo Desenvolvido (que é o que acontece na prática, durante as atividades de ensino-aprendizagem) e no Currículo Avaliado (que é revelador do que é na verdade valorizado no processo de ensino-aprendizagem) (SACRISTAN, 2000).

Por essa razão a avaliação do programa, de todos os aspectos e passos desse processo, é muito importante. Ela possibilita analisar se o que estamos fazendo é o que pretendemos; revela problemas que, se enfrentados, podem ajudar a superar limitações. A avaliação de currículo chegou ao Brasil nos anos 70 (SAUL, 2000) e, com raras exceções, não é uma prática institucionalizada e bem desenvolvida nas escolas médicas. O que mais comumente ocorre são as avaliações pontuais ao final de cursos ou disciplinas, por iniciativa dos próprios docentes e não da Comissão de Ensino ou do Comitê de Currículo.

Concepções pedagógicas mais modernas, principalmente quando envolvem o estabelecimento de relações mais democráticas entre professores e estudantes, provocam reações violentas dentro das escolas médicas. Talvez por 
isso mesmo seja muito forte o impacto provocado pela ruptura com as concepções tradicionais e pela adoção de metodologias ativas de ensino-aprendizagem, mudando papéis de alunos e de professores.

A desestabilização das relações tradicionais, que esse tipo de mudança tem o potencial de provocar, pode ser estratégica para que outras mudanças fundamentais possam ser introduzidas. Quebrar as relações de poder entre professores e estudantes e também as existentes entre os professores é fundamental para poder mudar as regras, por exemplo, em relação à definição de conteúdos e tempos, tornando-os função das necessidades de aprendizagem e não das relações de poder. Talvez por isso mesmo a resistência às mudanças dessa natureza tenha sido historicamente tão grande.

Outra questão importante é não confundir as partes com o todo: o projeto político-pedagógico inclui as concepções, as práticas, os conteúdos e os métodos. Os métodos fascinam, mas, como diz BORDENAVE (1998), a modernização dos métodos não garante por si mesma que a universidade se integre ao seu meio, se identifique com seus problemas e influa para mudar a realidade social. É preciso tratar especificamente da questão da mudança do conteúdo e das práticas porque elas não são decorrência automática de qualquer mudança metodológica (em alguns casos, sim, isso ocorre). Aliás, Flexner defendia uma proposta pedagógica que rejeitava a passividade e defendia que o estudante fosse ativo, envolvido em atividades de investigação e não ficasse restrito a escutar e a memorizar (FLEXNER, 1910).

A possibilidade de uma compreensão integral do ser humano e do processo saúde-doença, objeto do trabalho em saúde, passa necessariamente por uma abordagem interdisciplinar e por uma prática multiprofissional. Abordagem interdisciplinar na construção do conhecimento, chegando, pelo menos, a interações recíprocas e a uma colaboração entre disciplinas diversas. Abordagem interdisciplinar que implique na demolição das fronteiras entre pesquisa e ensinoaprendizagem (DEMO, 1998). 
Bem diferente do excesso de conteúdos, da falta de integração básico-clínico e de teoria-prática que acontecem o tempo todo nas escolas médicas. A superação dessas dificuldades passa pela adoção/construção de um currículo integrado, em que as disciplinas deixem de existir autonomamente e passem a contribuir com conteúdos específicos dentro do processo de formação. Módulos temáticos por ciclo vital, unidades por sistemas... são várias as possibilidades de reorganização dos conteúdos. Melhor ainda se a abordagem desses conteúdos se fizer a partir de interrogantes concretos, baseando-se em sua utilização prática.

Uma mudança curricular, com esses objetivos, tem que ir muito além de redistribuir carga horária e "trocar disciplinas de lugar", marca característica das tentativas de mudança anteriores. Implica uma mudança de poder: as disciplinas e departamentos deixam de dispor livremente de seu tempo e de seus conteúdos para fazer parte de um jogo mais amplo, em que a participação de cada um está subordinada a um plano mais geral de formação, construído com base em grandes acordos coletivos e gerenciado por um comitê curricular ou similar.

As principais tentativas de mudanças curriculares na educação médica brasileira esbarraram, fundamentalmente, em concepções limitadas do que seria a mudança; inadequações dos cenários de prática aos objetivos pretendidos; baixa capacidade do núcleo coordenador da mudança para romper com a lógica das disciplinas (mesmo nos blocos de integração vertical por sistemas, só se conseguia uma justaposição de disciplinas); falta de capacitação pedagógica do corpo docente e, principalmente, limitações graves de poder - como veremos mais adiante (RODRIGUEZ, 1995)

\subsubsection{A construção do saber médico}

Compreender como se constrói o saber médico é fundamental para propor melhores alternativas para seu processo de educação. A maior parte das tentativas de mudança, no entanto, passou ao largo desta discussão. 


\subsubsection{O saber médico e a ciência}

A medicina, desde a anatomia e anatomia patológica e especialmente a partir da era microbiológica, tornou-se científica. A educação médica, a partir de Flexner, passou a ser entendida como um processo de iniciação a uma ciência, - a medicina - ao lado da biologia, da física e da química. A prática médica, conseqüentemente, seria aplicação e produto dessa ciência, e o raciocínio clínico seu método próprio.

"Duas circunstâncias mediaram a transformação da medicina de empirica a científica: o desenvolvimento da fisica, da química e da biologia e a elaboração a partir delas de um método aplicável tanto à pesquisa como à prática. [...] Qual seria a importância do método científico para a prática clínica? [...] A principal ferramenta de um pesquisador é a elaboração de hipóteses. O cientista é confrontado por uma situação definida; ele a observa com o objetivo de extrair todos os fatos. Estes sugerem a ele uma linha de ação. Como dizemos, ele constrói uma hipótese. Orientado por essa hipótese, ele age e os resultados obtidos confirmam-na, desconfirmam-na ou modificam-na. Sua mente navega entre a teoria e o fato, e a teoria é útil e importante na exata medida em que o capacita a entender, descrever $e$ controlar os fenômenos" (FLEXNER, 1910).

$\mathrm{O}$ instrumento fundamental na passagem da medicina empírica para a científica foi, portanto, a investigação científica, pois através dela a prática médica podia estar cientificamente fundamentada. A educação médica, então, passou a ser vista como um processo de capacitação no método científico e a articulação entre prática clínica e pesquisa laboratorial tornou-se essencial.

Os médicos utilizam a teoria [da doença] para formular hipóteses quando estão diante de um paciente. A construção do raciocínio clínico e das hipóteses diagnósticas certamente é informada pelo método científico. 
Mas o caráter científico da prática clínica é relativo por algumas razões. Primeiro, pela singularidade de cada pessoa e, portanto, do doente. Singularidade histórica, que se revela em múltiplas dimensões - social, cultural, psicológica e até mesmo biológica - e que insiste em particularizar e diferenciar o fenômeno patológico da doença em cada pessoa. As ferramentas da ciência biológica são insuficientes para apreender essa singularidade.

Segundo, o olhar fragmentador das ciências médicas também não penetra na existência compacta de cada ser humano e em sua tendência de reagir como um todo indissociável na relação com as demais coisas e eventos do mundo (SAYD, 1998).

Em terceiro lugar, o caráter científico da prática clínica restringe-se pela necessidade de prescrever um tratamento, de prestar assistência e alívio ao sofrimento dos doentes e, quem sabe, de curar sua doença: ou seja, pela necessidade de utilizar a terapêutica. E a terapêutica é um terreno crítico para a medicina.

Crítico porque "por mais controladas que sejam as condições da pesquisa, os resultados finais na farmacologia ainda permitem poucas teorizações e estão mais entregues ao acaso do que outras práticas experimentais" (DUBOS IN SAYD, 1998). A análise in vitro dá conta de uma parte da reação do organismo e mesmo a análise in vivo é apenas parcialmente generalizável, pois de uma pessoa para a outra e, de acordo com as circunstâncias, as reações podem ser heterogêneas, mas há uma variabilidade muito ampla na resposta individual às drogas. Tanto assim, que o livro de farmacologia mais utilizado pelos estudantes (GOODMAN \& GILMAN in SAYD, 1998) recomenda ao médico considerar cada tratamento individual como um experimento porque, por mais testada que seja a droga, a imprevisibilidade persiste.

Além disso, na farmacologia não se pode, ainda hoje, dispensar o empirismo, pois 
"os conceitos da terapêutica têm avançado enormemente graças ao observador clínico que faz anotações cuidadosas e controladas das conseqüiências de uma intervenção terapêutica...Muitas vezes, a sugestão inicial de que determinada droga possa ser eficaz em certas condiçōes nasce de observaçōes empíricas cuidadosas, que foram feitas enquanto aquela droga estava sendo utilizada com outros propósitos" (GOODMAN in SAYD, 1998).

A terapêutica também é um terreno crítico para a medicina porque insiste em desviar o olhar clínico da doença para o doente. A busca do tratamento causal sempre enfraquece as especificações do tratamento relativas às características da pessoa, valorizando as características da doença. Se o que orienta a intervenção terapêutica é a ação sobre a causa da doença, é possível que se aceitem os efeitos colaterais dos remédios, coisa inadmissível se o foco estiver sobre o indivíduo e sobre suas necessidades.

Por conta dessa cientificidade limitada, tanto quanto lhe permitiam as possibilidades (também limitadas, porque afinal as pessoas continuam a adoecer, sofrer e morrer e a demandar um terapeuta nesses momentos), a medicina desvalorizou o discurso terapêutico. A figura social do médico vinculou-se profundamente à de homem da ciência e a atividade terapêtica foi caracterizada como algo estritamente privado, de que pouco se fala.

Assim como o cientificismo varreu para a esfera privada toda a dimensão subjetiva do mundo, desqualificou na prática médica as ferramentas vistas como não científicas e valorizou as ditas científicas, invertendo prioridades: preferindo a doença ao doente, fragmentando o todo, reduzindo o indivíduo a uma somatória de órgãos e sistemas, ignorando tanto sua especificidade biológica, como suas dimensões psicológicas, culturais e sociais.

CANGUILHEM (1990), por exemplo, diz que

"a medicina é uma atividade que tem raizes no esforço espontâneo do ser vivo para dominar o meio e organizá-lo segundo seus valores de ser vivo. É 
nesse esforço espontâneo que a medicina encontra seu sentido, mesmo não tendo encontrado antes toda a lucidez crítica que a tornaria infalível. Eis porque, sem ser ela própria uma ciência, a medicina utiliza os resultados de todas as ciências a serviço das normas da vida" .

A medicina, portanto, existe em primeiro lugar porque os homens se sentem doentes e somente secundariamente como instrumento para conhecer a doença. Ou seja, não é através de um método objetivo que se define como patológico um determinado fenômeno biológico. É sempre a relação com o indivíduo doente, por intermédio da clínica, que justifica a qualificação do patológico. Por isso mesmo foram as doenças que deram origem à fisiologia; e não foi a fisiologia e sim a patologia e a clínica que deram início à medicina.

É a própria vida que introduz na consciência humana as categorias de saúde e doença. Essas categorias são biologicamente técnicas e subjetivas e não biologicamente científicas e objetivas.

"Na medida em que a análise anatômica e fisiológica dissocia o organismo em órgãos e em funções elementares, ela tende a situar a doença ao nivel das condições anatômicas e fisiológicas parciais da estrutura total ou do comportamento de conjunto. Conforme progride a minúcia da análise, a doença será colocada ao nível do órgão, do tecido, da célula. Mas assim procedendo, esquecemos que historicamente, logicamente $e$ histologicamente chegamos até a célula a partir do organismo total e como pensamento, ou talvez mesmo o olhar, voltado para ele. Procurou-se no tecido ou na célula a solução de um problema levantado para o organismo inteiro e que se apresenta primeiro para o doente e, em seguida, para $o$ clínico" (CANGUILHEM, 1990).

Através dessas contradições podem ser compreendidos alguns dos problemas crônicos dos cursos de medicina, pois no afã de afirmar o caráter científico da medicina:

- as disciplinas básicas ganharam valor absoluto e perderam sentido aplicado, fragmentando-se em relação à clínica; 
- desenvolveu-se o olhar em direção à doença e não ao doente e fragmentou-se o todo que deveria ser indissociável;

- valorizaram-se as ferramentas "científicas" (restritas ao campo da biologia) de aproximação à doença e desvalorizaram-se todas as outras dimensões que favoreceriam o olhar sobre a pessoa como um todo - sociais, psicológicas e até terapêuticas - consideradas não ou pouco científicas.

\subsubsection{A incorporação de outros campos de conhecimento ao saber médico}

As ciências físicas e biológicas que conformam a base do saber médico não dão conta de instrumentalizar completamente o médico para produzir respostas adequadas em sua prática clínica - já que o ser humano tem outras dimensões que não a biológica, que cumprem papel fundamental em seu processo de viver, adoecer, reagir à doença e ao tratamento, morrer etc (CANESQUI, 2000); (ALMEIDA FILHO, 2000).

Conhecimentos e conceitos advindos da psicologia e da antropologia podem ajudar o médico a aproximar-se dos universos distintos de que fazem parte alguns de seus pacientes e a conseguir vislumbrar a existência de outras lógicas e valores. E, então, torná-lo capaz de aproximar-se da compreensão a respeito dessas lógicas que orientam determinados sentimentos, comportamentos e atitudes. Conhecimentos advindos da sociologia ajudariam o médico a identificar e compreender os aspectos sociais, suas repercussões sobre a maneira das pessoas de estar no mundo e, conseqüentemente, sua influência sobre o processo saúdedoença.

Esses conhecimentos são parte do instrumental necessário para se levar em conta o contexto em que vivem as pessoas, o que é importante no momento de estabelecer relações, interpretar situações, analisar causas e propor soluções para os problemas. Essas contribuições potenciais são reconhecidas já há muitos anos e a maneira de incorporá-las ao processo de formação tem sido principalmente sua 
introdução como disciplinas no currículo médico e na pós-graduação, especialmente na área de Saúde Coletiva.

Na esfera da pós-graduação a aproximação foi mais bem sucedida, pois são inúmeros os cursos, os núcleos de investigação e rica a produção de conhecimento na área. Já na graduação, a estratégia de inserir essas ciências como disciplinas tem se revelado pouco potente, já que tem sido muito limitada a capacidade dessas disciplinas de influir no núcleo duro da formação dos médicos (CANESQUI, 2000).

Uma das explicações para essa fragilidade está na maneira como esses saberes vem sendo introduzidos no universo da graduação: de maneira tão fragmentada quando os conhecimentos de certas especialidades médicas são introduzidos dentro da formação geral. E com um olhar tão equivocado quanto o das ciências básicas, por exemplo, quando tentam ensinar fisiologia aos estudantes de medicina como para um fisiologista (quer dizer, desarticulado da clínica e do saber médico).

Mas não tem sido somente na esfera da clínica que ocorrem as dificuldades para a incorporação desses outros saberes ao núcleo duro da medicina. Também no campo da epidemiologia isso tem ocorrido, pois seus instrumentos básicos promovem um apagamento da dimensão singular humana ao traduzi-la em códigos matemáticos e deslocar o nível subjetivo-pessoal-individual para o nível dos coletivos-agregados-populações. A existência do campo da epidemiologia social na América Latina contemplou mais eficientemente a conformação de um discurso de reconhecimento da determinação social do processo saúde-doença do que a criação de um instrumental que permita concretizar a articulação desses saberes no estudo da saúde das populações (ALMEIDA FILHO, 2000).

No campo da educação de graduação, falta construir maneiras de trabalhar esses conteúdos com estudantes e profissionais que não são e não serão "da área". Quer dizer, desenvolver abordagens não reducionistas, mas ao mesmo tempo 
acessíveis e compreensíveis, de modo a que esses conhecimentos possam ser apropriados e utilizados pelos médicos.

Além disso, até o momento, as contribuições desses outros campos para a compreensão do processo saúde-doença serviram para revelar a complexidade do fenômeno, mas não agregaram novas capacidades de ação para o médico em sua prática clínica. Ao contrário, dependendo da maneira como são introduzidas, aumentam a sensação de impotência dos médicos, o que certamente ajuda a que essas idéias sejam rejeitadas na prática.

Falta, então, transformar essas contribuições de outros saberes em ferramentas que aumentem a capacidade do médico de compreender e agir sobre a realidade. Tanto no âmbito da clínica como da epidemiologia, portanto, é necessário avançar "além de conceder certa intromissão do social por dentro de modelos de enfermidade clinica ou epidemiologicamente concebidos" (ALMEIDA FILHO, 2000)

Parece-me haver duas questões conceituais centrais, que influem decisivamente na possibilidade de se conseguir incorporar ou não outras dimensões ao pensamento médico: uma é a concepção de saúde-doença e a outra é a concepção de homem.

Enquanto predominar o conceito centralmente biológico de processo saúdedoença, as ferramentas identificadas, pelos médicos, como úteis para dar conta dos problemas serão as biológicas.

Essa "tarefa epistemológica", no entanto, é complexa e está relacionada a "transformaçōes radicais do sistema de formação dos sujeitos da ciência, que propiciem a integração global de um conhecimento coletivamente construido" (ALMEIDA FILHO, 2000).

Ou seja, a ruptura das barreiras disciplinares é parte do processo de ruptura de barreiras entre a filosofia e a ciência, entre as ciências "exatas" e as ciências sociais e de superação do racionalismo moderno (SANTOS, 2000); (RORTY, 2000).

A filosofia, por exemplo, deixaria de funcionar como Tribunal da Razão Pura e passaria ser a mediadora e propiciadora de um processo de transição, de 
ruptura de barreiras entre os saberes. A filosofia facilitaria a criação de pontes entre setores da reflexão, ampliando a capacidade humana de justificação e tornando mais sutil sua sensibilidade (RORTY, 2000).

Parte dessa ruptura de barreiras acontece ao compreender que todo objeto de trabalho é um objeto construído: no campo das práticas essa construção é realizada ao longo da história e no campo dos saberes é realizada em um tempo e momento próprios. Essa compreensão tem uma dupla conseqüência: sobre a história e sobre a ciência, pois ao estabelecer uma relação de integração entre ambas, confere à história seu sentido pleno e à ciência, sua capacidade crítica e transformadora (TESTA, 1992).

Entretanto, o diálogo e a negociação na construção de um novo paradigma não ocorreria somente ao nível da teoria, mas também da prática: nos laboratórios, nas salas de aula, nos colóquios, nas revistas científicas, nos seminários sobre as "contest-convers-ações" das ciências concretas, historicamente determinadas (ALMEIDA FILHO, 2000).

A importância de situar exatamente a complexidade da questão envolvida nessa "derrubada de muros" entre as ciências e as disciplinas é a de não nos satisfazermos com formulações simplistas em relação à construção do campo da saúde no plano teórico, epistemológico. No terreno da prática, essa compreensão contribui para sabermos que não é somente no âmbito da clínica que há dificuldades de incorporar "o social" na compreensão sobre o processo saúdedoença e em suas ferramentas operativas, já que elas também existem no campo da saúde coletiva, especialmente no terreno da epidemiologia. Como conseqüência, fica "borrado" o perigoso mapa "dos bandidos e mocinhos" na árdua tarefa de incorporar o social à saúde.

Como contribuição ao processo de construção desse novo no âmbito da prática, ouso dizer ser fundamental que a incorporação dos conhecimentos vindos das outras áreas sirva para agregar potência aos atos médicos e ao processo de produção de saber sobre a saúde e a doença. 


\subsubsection{O papel da prática na construção do saber}

A prática profissional dos médicos historicamente tem sido transmitida através de treinamento em serviço. É no processo de combinar os conhecimentos teóricos adquiridos com a experiência clínica (relacionamento com pacientes incluído aí) que se encontra a "mágica" da prática profissional médica. Somente a experiência adquirida na prática pode completar a formação [científica] do médico: é através da experiência clínica que o profissional se apropria dos doentes (e não mais apenas das doenças). É através da prática que se constrói a experiência clínica e é através da aprendizagem em serviço que o futuro profissional constrói, pelo menos em parte, também a ética de suas relações com os pacientes, baseada no exemplo e na experimentação.

Já foi apontado o fato de o corpo científico de conhecimentos necessários à construção do saber médico ter sofrido ampliação ininterrupta no processo de desenvolvimento científico e tecnológico. Também já foi comentado que a reconstrução da autonomia profissional médica baseou-se no acúmulo e intensidade da cientificidade possibilitada pela incorporação de tecnologia.

Ora, a utilização progressivamente maior de tecnologia na prática médica e a utilização de evidências tornam mais objetiva [e científica] a apreensão da realidade pelo médico e as suas intervenções sobre ela, aliadas à lógica racionalista, praticamente excluíram a necessidade de considerar os aspectos subjetivos do paciente para se chegar a uma abordagem correta de seus problemas. E essa é uma consideração/restrição a ser feita ao uso da medicina baseada em evidências: ela pode ser uma boa ferramenta para orientar as decisões e para a busca crítica de informações, mas não substitui a consideração da situação específica de cada pessoa.

Atualmente o treinamento prático dos estudantes de medicina inicia-se efetivamente no internato, obrigatório nas escolas médicas brasileiras com um ou 
dois anos de duração. Ao longo do curso, portanto, há uma separação bastante radical entre teoria e prática, pois durante os primeiros quatro anos da graduação existe um predomínio absoluto da transmissão de conhecimentos teóricos sem nenhuma relação com o enfrentamento de problemas práticos.

Se em tempos passados o curso organizado dessa maneira propiciava a terminalidade, que teria acontecido para que ela se perdesse? Uma das explicações certamente se encontra na influência das especialidades dentro da formação de graduação.

A multiplicação e a fragmentação de conteúdos, introduzidos sem critérios de relevância, dificultam ainda mais a hierarquização e a integração dos conhecimentos por parte dos estudantes. Assim como a multiplicação dos procedimentos a serem aprendidos compromete a possibilidade de aquisição de habilidades pelo estudante. Multiplicaram-se os procedimentos mínimos "indispensáveis" e, conseqüentemente, ficaram reduzidas as oportunidades de experimentá-los e executá-los da maneira e na intensidade adequada (ou seja, fazer muitas vezes).

Isso ocorre especialmente porque não estão claros ou estabelecidos os critérios para definir quais são os procedimentos relevantes, que devem ser dominados pelo conjunto dos profissionais durante a graduação e quais são específicos, e devem ser parte da formação especializada.

O rico arsenal de propedêutica armada reduziu, como já se viu, a oportunidade [e a necessidade aparente] de contato entre o médico [estudante] e os pacientes. E essa perda de qualidade e intensidade da relação entre médico [estudante] e paciente compromete o "potencial de apreensão" da clínica, do raciocínio clínico e da singularidade do paciente, inclusive nos estágios práticos existentes. Por isso mesmo, o estudante termina necessitando de mais tempo, de um maior número de contatos, para desenvolver e aperfeiçoar seus "mecanismos de apreensão". 
Atualmente o treinamento especializado através da Residência, transformou-se em complementação indispensável para a prontidão para o exercício profissional, pois é somente aí, depois da graduação, que existe a possibilidade de aquisição das habilidades e a incorporação de conhecimentos específicos acompanhados dos necessários critérios de importância, relevância e de maneira articulada com a prática.

Considerando o atual nível de desenvolvimento técnico e científico, não é possivel garantir a terminalidade da formação sem articular prática e teoria desde $o$ início da graduação e sem definir (e perseguir) muito claramente as competências necessárias para um médico com formação geral.

\subsubsection{Os cenários de ensino-aprendizagem}

Muitas experiências inovadoras desenvolvidas nas décadas de 70 e 80 tiveram como um elemento central a diversificação dos cenários de ensinoaprendizagem através da integração docente-assistencial.

Algumas (poucas) dessas experiências tiveram um impacto importante sobre o processo de formação, estimulando a que mudanças mais amplas acontecessem. A maioria, no entanto, teve muito pouco impacto, por conta de vários problemas (MARSIGLIA, 1995).

O primeiro deles é o tipo de relação que se estabelecia entre universidade e serviços: eram relações de subjugação. A universidade usava os serviços como cenários, para realizar as atividades que ela mesma considerava importantes. Gerava demandas que não sustentava nos períodos de férias, não levava em conta as necessidades identificadas pelos serviços, não incorporava seus profissionais em nenhuma etapa do processo.

Ou seja, a universidade descaracterizava o espaço dos serviços como local privilegiado de produção de serviços para, unilateralmente, transformá-lo em espaço privilegiado de aprendizagem. Ao "coisificar" os serviços, ao reduzi-los à 
figura de cenários, perdia-se também a possibilidade muito enriquecedora de interação entre sujeitos vindos de lugares sociais distintos.

O segundo aspecto crítico das experiências IDA foi que elas pretendiam provocar mudanças gerais na formação a partir de experiências isoladas, que envolviam geralmente os departamentos de preventiva e de pediatria. Na verdade, começaram isoladas e continuaram sempre isoladas na maior parte dos casos porque a capacidade de influência desses departamentos, especialmente os de preventiva, é muito baixa dentro das escolas médicas em geral (FEUERWERKER, 1998).

Para cumprir um papel transformador há que compreender "Cenários de Aprendizagem" como um conceito amplo, que diz respeito não somente ao local em que se realizam as práticas, mas aos sujeitos nelas envolvidos, à natureza e conteúdo do que se faz etc. Diz respeito, portanto, à incorporação e à inter-relação entre métodos didáticos pedagógicos, áreas de práticas e vivências, utilização de tecnologias e habilidades cognitivas e psicomotoras e que inclui, também, a valorização dos preceitos morais e éticos orientadores de condutas individuais e coletivas (REDE UNIDA, 2000b).

Diz respeito aos processos de trabalho, ao deslocamento do sujeito e do objeto do ensino e a uma revisão da interpretação das questões referentes à saúde e à doença, considerando-se sua dinâmica social. Por conta dessa dinâmica, é necessário que existam mecanismos permanentes de ajustes da organização dos cenários de aprendizagem quando se busca estudar "a" e "na" realidade (REDE UNIDA, 2000b).

A diversificação de cenários de ensino-aprendizagem é, ao mesmo tempo, uma estratégia para induzir mudanças mais profundas no processo de formação profissional e um elemento, em si mesmo, constitutivo de uma nova maneira de pensar a formação profissional.

As experiências mais avançadas nesse terreno têm o propósito de não transformar o espaço dos serviços de saúde e da comunidade em prolongamentos 
do hospital universitário e dos centros de saúde-escola. Ou seja, não se pretende descaracterizar os cenários reais como local de produção de serviços. Ao contrário, a construção dos espaços de aprendizagem se dá através da incorporação de estudantes e docentes ao processo de produção de serviços. Sem dúvida, essa interação produz mudanças nesse processo, mas sem descaracterizar sua natureza.

Neste sentido, a construção de ações e estratégias de controle de doenças e promoção de saúde, da formação dos recursos humanos, do controle social, da educação e da comunicação em saúde, da integralidade da atenção, da intersetorialidade, da equidade, passam a fazer parte das agendas e perspectivas de intervenção de docentes, estudantes e dos profissionais dos serviços.

Para isso, é necessário estabelecer relações mais horizontais de cooperação entre os atores envolvidos, incluindo os representantes da população, de modo que se possa, de fato, incorporar, ao processo de ensino-aprendizagem, as diferentes realidades nas quais se produz e reproduz o processo saúde-doença.

Isso é fundamental para que a ação pedagógica possa adquirir maior amplitude conceitual e metodológica, pois a participação de novos sujeitos nesses cenários mostra-se a maneira mais eficaz e verdadeira de trazer novos temas e desafios ao processo de produção do conhecimento e de ensino-aprendizagem (REDE UNIDA, 2000b).

É muito importante envolver nesse trabalho os docentes de outras áreas, que não a saúde coletiva/medicina preventiva. Há várias experiências, nacionais e internacionais, de participação de docentes das carreiras básicas nesse tipo de trabalho, com ótimos resultados (FEUERWERKER \& SENA, 1999).

Existe, desse modo, a possibilidade de produzir, a partir dessas experiências, alternativas pedagógicas mais favoráveis à articulação entre teoria $\mathrm{e}$ prática, ensino e trabalho e à adoção de enfoques interdisciplinares. Isso porque a necessidade de dar respostas a problemas práticos se converte no motor da busca e construção do conhecimento por parte dos estudantes, docentes e de todos os 
envolvidos. Com a vantagem adicional de existir a oportunidade de experimentar e analisar criticamente as soluções na prática.

Proponho aqui uma outra hipótese: para aumentar a possibilidade de impacto dessas experiências dentro das escolas elas deveriam ser propostas e construídas dentro da grade curricular e do tempo regulamentar de trabalho de docentes e estudantes. Podem até começar como eletivas ou optativas, mas que estejam inseridas e pensadas como atividades de graduação e não como atividades de extensão.

Há várias experiências brilhantes de ação intersetorial construídas no espaço da extensão, que propiciaram avanços importantes para a organização de comunidades no enfrentamento de temas complexos como a violência (PROJETO UNI BAHIA, 2001) e a produção de conhecimentos relevantes (GUIMARÃES, 1997), porém com impactos limitados sobre a organização da graduação.

Claro que as atividades de extensão são importantes e abrem espaço para que outras propostas de cooperação entre estudantes, docentes e comunidade se concretizem. Mas para produzir impacto sobre o processo de formação profissional, seu compromisso e sua relevância social, essas atividades devem estar inseridas no coração da prática de docentes e estudantes (e não nos espaços marginais).

Pensado dessa maneira, o trabalho nos outros cenários é uma proposta de tomar os problemas da realidade como objeto da docência e da produção de conhecimentos, que se concretizariam como práticas articuladas, inscritas no mundo do trabalho, ou seja, na "produção de serviços".

\subsubsection{As práticas clínicas}

Não basta estabelecer práticas e relações inovadoras nos cenários novos - da comunidade e da atenção básica - que são incorporados no processo de ensinoaprendizagem. Para transformar o perfil do profissional formado, é preciso 
transformar as práticas e as relações em todos os cenários de prática, incluindo os de internação domiciliar, os ambulatórios de especialidade, as enfermarias e os pronto-socorros.

Nas experiências IDA, e também em vários projetos UNI, houve uma compreensão muito restrita sobre a mudança do modelo de atenção, reduzindo-a à introdução/fortalecimento das práticas de promoção e prevenção e à ação no espaço da atenção primária. Por essa razão, trabalhou-se a contradição saúde/doença, expandindo o trabalho com a saúde de maneira significativa, mas não se conseguiu trabalhar adequadamente a transformação do espaço da doença. Ou seja, não se investiram esforços na necessária reinvenção da prática clínica, na reconstrução do aspecto cuidador da prática de todos os profissionais de saúde.

Segundo MERHY (1997) o trabalho em saúde não pode ser globalmente capturado pela lógica do trabalho expresso nos equipamentos e nos saberes tecnológicos estruturados, pois seu objeto não é plenamente estruturado e suas tecnologias de ação mais estratégicas se configuram em processos de intervenção em ato, operando como tecnologias de relações, de encontro de subjetividades, para além dos saberes tecnológicos estruturados.

Por isso as tecnologias envolvidas no trabalho em saúde são classificadas por esse autor como leve (como no caso das tecnologias de relações do tipo produção de vínculo, autonomização, acolhimento, gestão como forma de governar processos de trabalho), leve-dura (como no caso de saberes bem estruturados que operam no processo de trabalho em saúde, como a clínica médica, clínica psicanalítica, epidemiologia) e dura (como no caso de equipamentos tecnológicos como máquinas, normas, estruturas organizacionais).

O trabalho vivo em saúde se materializa através do processo de produção de relações entre os cuidadores e o usuário final que, com suas necessidades particulares de saúde, dá aos profissionais a oportunidade de tornar públicas suas distintas intencionalidades no cuidado da saúde, tornando-se responsáveis pelos resultados da ação cuidadora. Todos os trabalhadores de saúde de alguma maneira 
são cuidadores e desenvolvem essa tecnologia de construção de vínculos, de oferecer ao usuário em alguma medida os cuidados e a atenção de que ele necessita.

Reinventar essas relações, ampliando o espaço para a responsabilização, o acolhimento e a autonomia progressiva dos usuários, é um dos elementos centrais da construção de um modelo de atenção integral e uma outra estratégia para ampliar a clínica, dando outro tratamento ao espaço da doença.

Outras estratégias têm sido usadas com esse mesmo objetivo: por exemplo, a abertura de espaço para a presença contínua das mães dentro de uma enfermaria infantil no Hospital Giselda Trigueiro em Natal foi o pretexto para uma reorganização total do trabalho da equipe, das relações e dos papéis de cada profissional e das relações da equipe com as mães e as crianças (BARBOSA \& ROCHA, 1999).

São possíveis muitos outros caminhos. O importante é que esse esforço seja feito em todos os espaços, inclusive no hospital, invertendo a lógica de sua organização, privilegiando as necessidades dos pacientes, organizando o trabalho de maneira multiprofissional. Os sujeitos dessa reivenção têm que ser os profissionais de saúde, que cumpririam, então, papel fundamental na mudança da formação e do modelo de atenção (CAMPOS, 1994).

Sem inovar nas práticas clínicas e no terreno da relação médico-equipe e médico-paciente não será possível avançar com radicalidade nos processos de mudança da formação médica.

\subsubsection{A avaliação}

Apesar dos avanços verificados em relação à temática da avaliação institucional na universidade brasileira (o Programa de Avaliação Institucional das Universidades Brasileiras - PAIUB - e o trabalho produzido através da Comissão Nacional de Avaliação do Ensino Médico - CINAEM são bons exemplos disso), a 
avaliação da aprendizagem ainda é uma área de baixo desenvolvimento - como prática e como área de produção de conhecimento.

No entanto, ela é um terreno estratégico de transformação dentro de uma proposta de mudança das relações e dos papéis desempenhados por professores e estudantes no processo de ensino-aprendizagem e não foi abordada com profundidade nas tentativas de mudança dos últimos 30 anos.

Problemas comuns na avaliação da aprendizagem nas escolas médicas são a utilização quase exclusiva da avaliação ao final da disciplina, cognitiva (com ênfase na memorização de conteúdos); a valorização de aspectos menos importantes do conteúdo das disciplinas; a desvalorização de mecanismos de avaliação diferentes da prova; a competitividade entre os estudantes (LÜDKE \& SALLES, 1997). E no internato, geralmente há práticas opostas: muitas vezes não há mais provas e sim "avaliações de desempenho", que muitas vezes são feitas de modo muito subjetivo, sem que existam critérios conhecidos por todos.

A avaliação da aprendizagem tem pelo menos 5 propósitos: coletar informações sobre o desempenho dos alunos para aperfeiçoar o processo de ensino-aprendizagem; identificar os interesses de cada estudante para orientação vocacional;julgar quais experiência educacionais são mais úteis para diversos grupos de estudantes; verificar se os programas educacionais estão provocando reais mudanças; proporcionar elementos para que o professor possa planejar o nível e o tipo de atividade educacional adequados (DEPRESBITERIS, 1989).

A avaliação pode ser feita antes (diagnóstica), durante (formativa) e ao final (somativa) de um determinado momento de ensino-aprendizagem. De acordo com os objetivos educacionais ${ }^{1}$, pode estar voltada a avaliar conhecimentos (cognitiva),

\footnotetext{
${ }^{1}$ Os objetivos educacionais são caracterizados por um binômio conteúdo-comportamento. A taxonomia de Bloom classifica os objetivos segundo seu aspecto comportamental e estabelecendo uma hierarquia na qual uma categoria mais avançada representa um comportamento mais complexo, abstrato ou internalizado que o anterior. A taxonomia de Bloom prevê três dominios: cognitivo (interessando os objetivos de cunho intelectual e que podem ser trabalhados em vários niveis: conhecimento, compreensão, aplicação, análise, síntese, avaliação); afetivo (interessando atitudes e graus de internalização, trabalhados nos seguintes niveis: recebimento, responsividade, valorização, organização e caracterização de um valor ou complexo de valores) e psicomotor (interessando os objetivos em que se executam atos e se lida com a motricidade, trabalhados nos
} 
atitudes (afetiva) ou habilidades (psicomotora) e pode ser realizada através de metodologias quantitativas ou qualitativas.

Para qualquer dessas modalidades é importante definir objetivos de aprendizagem para aquele momento do curso; comparar esses objetivos de aprendizagem específicos com os gerais (do curso como um todo - para que sejam coerentes); avaliar o produto ou o resultado da atividade (DEPRESBITERIS, 1989).

Outra questão importante é a dos padrões de referência avaliativa. Há padrões absolutos, que se apóiam nos objetivos educacionais e geralmente são usados para as avaliações somativas. Há também padrões relativos, que são baseados em grupos de referência e podem ser de dois tipos, referentes a critério e referentes à norma. Os testes referentes a critério são planejados para obter informações sobre conhecimentos e capacidades específicos do estudante; geralmente abrangem unidades de conteúdo relativamente pequenas e servem para saber o que o estudante pode ou não fazer; são muito úteis para avaliação formativa.

É fundamental que todos conheçam previamente os critérios e as condições do processo avaliativo. É também importante que existam diversas fontes de informação para evitar os vieses técnicos e pessoais. Entre essas fontes estão: o próprio estudante (autoavaliação), os colegas (avaliação interpares), os profissionais dos serviços e a própria comunidade. Existe uma série de instrumentos e formatos avaliativos, quantitativos e qualitativos, mais adequados uns ou outros, dependendo dos objetivos da avaliação.

A avaliação feita ao longo do processo de aprendizagem (formativa) é uma ferramenta muito útil, para professores e estudantes, para identificar problemas e possibilitar correções de rumo. Especialmente numa proposta de organização da aprendizagem que coloca o estudante como sujeito, esse tipo de retroalimentação é essencial.

seguintes níveis (movimentos de reflexo, movimentos básicos fundamentais, aptidões perceptuais, habilidades fisicas, movimentos hábeis e comunicação não-discursiva) (BLOOM, 1971) 
É importante procurar de fato avaliar todas as dimensões da aprendizagem e garantir que o conteúdo da avaliação seja coerente com os objetivos educacionais delineados. Os procedimentos para avaliação cognitiva são em geral mais fáceis de

operacionalizar que os destinados a avaliar habilidades. $\mathrm{Na}$ avaliação cognitiva, é importante buscar explorar outros aspectos que não somente os de retenção da informação, avançando para aplicação e análise.

A avaliação do processo de ensino-aprendizagem requer que sejam também avaliados o desempenho dos docentes e a organização e desenvolvimento do processo de ensino-aprendizagem, como já mencionamos.

De todo modo, avaliação é uma área nas quais as escolas em geral têm muito pouca experiência e é necessário que exista construção de capacidades para que as mudanças possam ser implementadas, de acordo com as possibilidades de cada contexto (LIMA \& SEIFFERT,2000).

As normas universitárias em relação a notas e critérios de progresso geralmente não ajudam muito - são rígidas e quantitativas - e também têm que ser alvo de revisão nos processos de mudança.

\subsection{O cenário político-social e econômico: condicionamentos e possibilidades de ação das iniciativas de mudança dos últimos $\mathbf{3 0}$ anos}

Como vimos, a educação médica está condicionada, em cada momento histórico, pelas macroestruturas e tendências econômicas, pela organização política e social em geral e em particular no setor saúde.

No entanto, existem graus de liberdade no funcionamento e comportamento das instituições formadoras, já que elas estão também condicionadas pelos confrontos dinâmicos e dialéticos entre projetos político-ideológicos de grupos sociais (PAIM, 1994).

As escolas médicas, portanto, podem oscilar entre propostas e projetos transformadores ou reprodutores do modelo hegemônico, a depender do resultado das disputas que se estabeleçam em seu interior (que estão também relacionadas 
com forças externas, como partidos políticos, entidades da corporação, movimentos sociais etc) (ROVERE, 1996).

Usando o referencial proposto por ALMEIDA (1999), pode-se compreender porque tem sido tão difícil mudar a educação médica no Brasil. As iniciativas de mudança procuraram enfrentar, nos últimos 30 anos, problemas importantes, tais como a fragmentação do ato médico, a perda de qualidade da relação médicopaciente, a exclusão de boa parte da população do acesso aos serviços em função da elevação astronômica dos custos, a introdução precoce da especialização levando à fragmentação de conteúdos e à perda da terminalidade. Além desses temas, algumas iniciativas pretenderam orientar a formação para a produção de médicos para trabalhar na atenção primária à saúde (SCHRAIBER, 1989).

Essas propostas, além de estarem endereçando mudanças da organização e da própria prática médica através das propostas de mudanças no processo de formação dos médicos (SCHRAIBER, 1989), constituíam-se em respostas fragmentadas e parciais, como pudemos ver, às conseqüências das transformações que a capitalização do setor saúde provocava na prática médica e na lógica da prestação de serviços.

Ou seja, as iniciativas de mudança se confrontaram global ou parcialmente com problemas gerados por um modelo de formação que estava sendo fortalecido por elementos estruturais da economia, do desenvolvimento tecnológico, da organização do trabalho e da produção do conhecimento em saúde. Para defrontar-se com questões tão complexas e interesses tão poderosos, as iniciativas de mudança não poderiam haver sido tão singelas como foram: restritas ao interior das escolas médicas (pior, a setores das escolas médicas), com limitada compreensão sobre a articulação dos vários elementos do problema que pretendiam superar, com baixa capacidade de formulação e muito pouca estratégia. Ou seja, naquele momento e sendo como eram, não havia condições subjetivas e objetivas para que as iniciativas de mudança pudessem fazer prevalecer seus projetos. 
No entanto, houve mudanças importantes no contexto que parecem abrir outras possibilidades para os movimentos de mudança no momento atual.

\subsubsection{O contexto atual}

Do ponto de vista da economia, as contradições e disputas no campo da saúde se intensificaram muito. Apesar de os setores produtores de equipamentos, remédios e de tecnologia continuarem sendo segmentos economicamente saudáveis e lucrativos, há dificuldades em manter a lógica da organização do modelo de atenção à saúde subordinada a seus interesses. Isso porque neste momento esses interesses setoriais são contraditórios com interesses do próprio Estado em outras esferas (que não a econômica), mesmo sendo este um Estado que privilegia o "livre jogo das forças do mercado".

Mesmo no cenário mais desfavorável, de progressiva desresponsabilização do Estado em relação à manutenção da saúde das populações, tornou-se financeiramente insustentável o modelo baseado prioritariamente na utilização intensiva de tecnologia, na especialização, no hospital e no médico (IBAÑEZ \& MARSIGLIA, 2000).

Nos últimos anos, em função disso, tem existido uma tendência à reorganização das práticas: tanto na área pública (buscando efetividade $\mathrm{e}$ diminuição de custos para garantir atenção universal) como na privada (buscando efetividade e diminuição de custos para garantir lucratividade). A ambulatorização dos cuidados - com o crescimento de uma atenção de menor custo, praticada por equipes menores - restrições e críticas quanto ao uso das tecnologias e das especialidades; incentivo à atenção domiciliar (SCHRAIBER, 2000).

Como decorrência imediata desse movimento de reorientação das modalidades de atenção, têm surgido - em várias partes mundo - demandas e pressões para que se formem profissionais com perfil e capacidades distintas das produzidas pelo modelo hegemônico de formação. 
No Brasil, o cenário é ainda mais favorável. Nas décadas de 70 e 80 , no bojo da luta pela democratização do país, organizou-se o movimento pela reforma sanitária brasileira, que culminou com a criação do SUS na Constituição de 1988.

Nos anos 90, configurou-se a existência de um expressivo contingente de atores sociais empenhados na construção do SUS: secretários municipais de saúde (e seus assessores) dos 521 municípios em gestão plena do sistema de atenção, secretários municipais e assessores dos 3000 municípios que mais avançaram na gestão plena da atenção básica, os conselhos que congregam (militantemente) os secretários municipais nos estados (COSEMS) e nacionalmente (CONASEMS), os milhares de trabalhadores da saúde, especialmente os participantes das equipes de saúde da família, os mais de 50 mil conselheiros de saúde - do Conselho Nacional de Saúde, dos 27 Conselhos Estaduais e dos mais de 3 mil Conselhos Municipais de Saúde - centenas de entidades e organizações não-governamentais que militam na área de meio ambiente, defesa da qualidade de vida e dos direitos do consumidor (SANTOS, 2000).

Sem dúvida, um contingente heterogêneo, mas que conquistou avanços inegáveis na constituição de espaços (mais ou menos) democráticos de negociação, como são as Comissões Bipartites, a Tripartite e os Conselhos, na descentralização da saúde, na ampliação da rede pública de serviços, no aumento da cobertura e do acesso (SANTOS, 2000).

A existência desse movimento social, de organicidade variável possibilitou defender o setor saúde da orientação geral de enxugamento do Estado e de diminuição dos investimentos públicos nas áreas sociais (SANTOS, 2000). Ao contrário, o avanço na construção do SUS tem implicado compromissos crescentes do Estado com o financiamento, a prestação e a regulação das ações em saúde (GERSCHMAN, 1997).

Ainda que complexo e contraditório, o movimento pela reorganização da atenção à saúde também vem avançando, especialmente com a estratégia da Saúde Família. E, em conseqüência, as pressões e demandas pelas mudanças na formação 
dos profissionais de saúde, especialmente dos médicos, também têm crescido e partido de distintos segmentos - dos usuários aos gestores de todas as esferas do sistema (CONFERÊNCIA, 2001); (CAMPOS \& BELISARIO, 2001).

As reações dos setores cujos interesses estão sendo ou tendem a ser contrariados não são pequenas e não podem ser desconsideradas. Basta ver a reação das associações e organizações médicas diante da tentativa (rapidamente abandonada) de regulação da organização da atenção médica na saúde supletiva (MERHY \& MAGALHÃES JUNIOR, 2001).

A corporação médica dá indícios de que vai resistir a todas os movimentos que impliquem uma mudança da configuração de poder dentro da categoria, como, por exemplo, será o redimensionamento do papel e a perda de espaço dos especialistas dentro do sistema de saúde. Certamente essa tendência terá repercussões nas posições que as organizações da corporação médica terão diante das propostas de mudança no terreno da formação.

No campo da educação, o padrão atual de organização da produção, ao lado do fenômeno paradoxal de ampliação do trabalho informal e da emergência da revalorização do trabalho em si, exigem do trabalhador capacidades de diagnóstico, de solução de problemas, de tomada de decisões, de intervenção no processo de trabalho, de trabalhar em equipe, de auto-organizar-se, de enfrentar situações em constante mudança, e até de inventar atributos e capacidades que viabilizem sua inserção profissional específica (DELUIZ, 1997).

Portanto, hoje, em qualquer área, formar profissionais com perfil adequado às necessidades sociais implica propiciar capacidade de aprender a aprender, trabalhar em equipe, comunicar-se, ter agilidade frente às situações, ter capacidade propositiva. São todas características genéricas, necessárias aos profissionais do futuro, que não combinam com a formação tradicional e com a pedagogia da transmissão que predomina nas universidades.

Esses desafios contribuem para que seja grande a pressão sobre as universidades pela adoção de metodologias que favoreçam o desenvolvimento do 
espírito crítico, da capacidade de reflexão e a participação ativa dos estudantes na construção do conhecimento.

As políticas oficiais, no entanto, são contraditórias. Pelo lado positivo, a nova Lei de Diretrizes e Bases - LDB - possibilita introduzir múltiplos mecanismos de flexibilização, que abrem espaço para a mudança qualificada e para a autonomia responsável. A exigência em relação à qualificação docente faz aumentar a procura por formação em pós-graduação, o que provavelmente será oportunidade interessante para repensar formatos, conteúdos, modalidades de oferta. Em relação às diretrizes, houve a possibilidade de debate aberto e de aprovação de propostas de acordo com as proposições ativas dos movimentos de mudança na formação profissional (REDE UNIDA, 2000a).

Além disso, houve a introdução de mecanismos de avaliação que tornaram pública a situação das universidades, suas virtudes, seus defeitos. Com todas as limitações e problemas que possam ter esses mecanismos atuais de avaliação, eles certamente estão provocando um movimento positivo (mais ou menos intenso e conseqüente, dependendo das características de cada instituição) de busca de soluções para problemas. O "Provão" e a "Avaliação das Condições de Oferta", portanto, converteram-se em combustível para acelerar e alimentar os movimentos de mudança da graduação. Há uma enorme inquietação no sentido da busca de soluções pedagógicas ativas.

Pelo lado negativo, há o desfinanciamento das universidades públicas, o sucateamento de instalações, o achatamento salarial que incentiva a fuga de quadros, a disponibilização preferencial de recursos do Banco Nacional de Desenvolvimento Econômico e Social (BNDES) para as instituições privadas, a restrição dos recursos disponíveis para investigação e bolsas de estudo.

Ainda assim existe um espaço público a ser disputado: as universidades públicas saem-se melhor na avaliação, são as que mais produzem cientificamente, motivos socialmente relevantes para que se estabeleça sua defesa. No entanto, só 
conseguirão apoio externo para suas necessidades de sobrevivência se forem capazes de mudar e de construir relevância social de verdade.

O Ministério da Saúde e o Ministério da Educação, no dia 18 de dezembro de 2001, lançaram um programa de incentivos às mudanças nos cursos de medicina - o PROMED. O programa pretende oferecer apoio técnico e financeiro para as escolas médicas que se dispuserem a entrar em processos de mudança que levem a um trabalho articulado com os serviços de saúde, à adoção de metodologias ativas de ensino-aprendizagem e à formação geral, crítica e humanista.

Este cenário, contraditório, abre novas perspectivas para o movimento de mudanças na formação dos profissionais de saúde e dos médicos em particular. No entanto, agora, compreendendo a complexidade do tema e das relações envolvidas, cabe estar melhor preparados para a construí-las. Tanto do ponto de vista da compreensão acerca do que se pretende transformar, como do ponto de vista das estratégias. 


\section{As propostas de mudança na educação médica na América Latina e no Brasil nos anos 90}

Apresento a seguir uma síntese muito breve das principais propostas de mudança da educação médica desenvolvidas na última década. Estão aqui incluídas as propostas que pretenderam se constituir como movimentos, com um ideário construído e estratégias propostas. Excluí a proposta de Gestão da Qualidade, construída pela Organização Panamericana da Saúde (OPS) no início dos anos 90, pelo fato de ela não ter sido nunca levada à prática. O objetivo desta apresentação é simplesmente situar seus principais conceitos operacionais.

Os projetos UNI de Londrina e de Marília, assim como os demais UNI, como participantes ativos do cenário da educação médica, estabeleceram contatos com todas elas e acabaram sendo influenciados, de um modo ou de outro, por aspectos relevantes de cada uma delas. No entanto o Programa UNI foi a proposta com maior poder de influência e conformação sobre os processos em análise.

\subsection{Changing Medical Education: an Agenda for Action}

Em 1991 a Organização Mundial da Saúde (OMS) lançou um documento chamado "Changing Medical Education: an Agenda for Action", que pretendia ser uma alternativa de coordenação e sistematização de atividades que possibilitassem a adaptação do ensino médico às novas exigências da sociedade (WORLD, 1991).

A iniciativa esperava conseguir mobilizar especialistas e recursos internacionais para implementar um programa pela melhoria da relevância social e eficiência da educação médica. A "Agenda for Action" indica que um dos principais motivos da insatisfação da sociedade em relação aos médicos e demais profissionais de saúde reside na sua incompetência em enfrentar os novos desafios colocados pela crise do paradigma atual da saúde: humanização da atenção, cuidado integrado, maior participação social, eqüidade, contenção de custos, uso 
adequado de tecnologia, proteção ao meio ambiente e promoção de estilos saudáveis de vida (FEUERWERKER,1998).

A proposta considera que quaisquer mudanças implementadas na educação médica levarão de dez a quinze anos para afetar de alguma maneira a prática e, por essa razão, indica a necessidade de articulá-las a estratégias que envolvam os atuais profissionais de saúde. Por isso propõe que as escolas tenham uma participação ativa na melhoria da qualidade e da cobertura dos serviços de saúde; busquem assegurar a relevância da educação e da pesquisa (vinculando-as às necessidades prioritárias de saúde); estejam dispostas a aplicar e disseminar processos de aprendizagem eficientes e comprometam-se com os processos de garantia de qualidade e de avaliação tecnológica.

Para dar sustentação a essa iniciativa, a OMS em 1992 iniciou a publicação de um boletim chamado "Changing Medical Education and Medical Practice", publicado em inglês, em espanhol e português (a tradução para as línguas latinas foi iniciativa dos projetos UNI, dois deles também Centros Colaboradores da OMS para Educação Médica). Em 1999, foi realizada uma Conferência em Phuket, Tailândia, em que foi lançado o movimento "Towards Unity for Health", com o objetivo de promover parceria e estudos colaborativos como estratégia de articulação.

\subsection{Network}

A criação da Network of Community-Oriented Educational Institutions for Health Sciences, mais conhecida como "NETWORK", ocorreu em reunião em Kingston (Jamaica) em 1979, promovida pelo Health Manpower Development Program da OMS/Genebra e pelo Programa de Desenvolvimento de Recursos Humanos da OPS/Washington (ALMEIDA, 1999).

Os antecedentes dessa iniciativa baseiam-se: 
- na decisão da Assembléia Mundial da Saúde, de 1977, que estabeleceu a meta de "saúde para todos no ano 2000";

- na Conferência de Alma-Ata, de 1978, que elegeu a atenção primária de saúde como estratégia prioritária para se atingir a referida meta e para cujo desenvolvimento os profissionais de saúde desempenham papel chave;

- na existência de vários programas ou experiências inovadoras no campo da formação de profissionais de saúde, especialmente em escolas médicas, distribuídos pelas várias regiões do mundo, sem haver, entretanto, intercâmbio entre eles.

Reconhecendo a necessidade de fortalecer esses programas ou experiências inovadoras, a OMS e a OPS decidiram promover um encontro entre os seus dirigentes para explorar as possibilidades de intercâmbio e de disseminação, com vistas a reforçar a implementação da Atenção Primária à Saúde (APS).

Foram convidadas vinte instituições, dez provenientes de países desenvolvidos e outras dez de países em desenvolvimento, selecionadas respectivamente pela OMS e pela OPS. Compareceram dezesseis instituições, consideradas fundadoras da NETWORK, dentre as quais seis instituições latinoamericanas.

A análise dos programas das instituições representadas na reunião revelou como suas principais características a orientação comunitária (community orientation) e o uso de abordagens de aprendizagem baseada em problemas (problem based learning). A diversidade de interpretações a respeito de seu significado levou os participantes a uma primeira tentativa de consenso em torno de definições operacionais acerca de três conceitos: educação baseada na comunidade, educação orientada à comunidade e aprendizagem baseada em problemas.

Conforme previsto, os participantes chegaram a um acordo sobre os benefícios mútuos que poderiam advir do desenvolvimento de uma ligação mais estreita entre essas instituições. A conexão em rede poderia também viabilizar a 
expansão gradual para outras escolas das metodologias e enfoques adotados. Decidiu-se, portanto, pela criação de uma Rede e se definiu a Universidade de Limburg, Maastricht, Holanda, como sede da sua secretaria-executiva.

Também se resolveu que seriam promovidas Reuniões Gerais, a cada dois anos. $\mathrm{O}$ apoio para a realização das atividades, nos anos iniciais, foi obtido junto à OMS, à Fundação Rockfeller, ao Governo da Holanda e à Faculdade de Medicina e de Ciências da Saúde da Universidade de Limburg.

Os objetivos estabelecidos para a nova organização foram: melhorar a cooperação entre serviços de saúde e o desenvolvimento da força de trabalho em saúde (health manpower); melhorar a APS e o nível de saúde na área de atuação das escolas; expandir a abordagem do ensino orientado a comunidade e da aprendizagem baseada em problemas para a formação de outros profissionais de saúde; aumentar o número e a eficácia de professores capacitados para desenvolver a abordagem preconizada; aumentar o número de líderes que apóiem a abordagem preconizada e, expandir o número de organizações que apóiem a proposta (WORLD, 1999).

As atividades mais relevantes, durante os anos iniciais, concentraram-se no aprofundamento da base teórico-conceitual, através da realização de estudos e da promoção de seminários de análise das experiências desenvolvidas por seus membros, inicialmente dezesseis. Com base nesse trabalho, chegaram à definição dos dois conceitos centrais do arcabouço teórico-metodológico da proposta (ALMEIDA, 1999).

A "educação orientada para a comunidade" é característica das instituições cujos objetivos e princípios básicos são determinados pelas necessidades da comunidade, cujos currículos adotam um enfoque integral da saúde e desenvolvem atividades comprometidas com a meta de saúde para todos.

A aprendizagem baseada em problemas é um método pelo qual o estudante ou o trabalhador de saúde utiliza a situação de um paciente, uma questão da assistência à saúde ou um tópico de pesquisa, como estímulo para aprender. Após 
análise inicial do problema, os estudantes definem seus objetivos de aprendizagem e buscam as informações necessárias para abordá-lo. Após, discutem o que encontraram e o que aprenderam, construindo uma abordagem coletiva sobre o tema. A aprendizagem baseada em problemas na educação dos profissionais de saúde tem três objetivos: a aquisição de um corpo integrado de conhecimentos, a aplicação de habilidades para resolver problemas e o desenvolvimento do raciocínio clínico.

Um elemento central da proposta a aprendizagem baseada em problemas é que a educação está centrada no estudante. Ou seja, a instituição deve propiciar todas as oportunidades e recursos para motivar o estudante a aprender com base em suas necessidades. Mas o estudante deve ter total responsabilidade por sua aprendizagem. A ênfase nesta estratégia é a busca ativa de informações e o desenvolvimento de habilidades pelo estudante. A ele compete definir as melhores formas e o ritmo de estudar, bem como a avaliação do progresso da sua formação (ALMEIDA, 1999).

A orientação comunitária, na maioria dos casos, se concebe como a incorporação, nos conteúdos curriculares, dos problemas prioritários de saúde, ou de atividades desenvolvidas em ambientes comunitários ou, ainda, em alguns casos, pela estruturação de serviços universitários de saúde de primeiro nível de atenção, que funcionam de forma muito semelhante à extensão universitária. Em essência, a concepção que preside a orientação comunitária da proposta se vincula ao compromisso de tornar a educação dos profissionais de saúde mais relevante em relação às necessidades da sociedade, definidas, essencialmente, através dos perfis epidemiológicos das populações (ALMEIDA, 1999).

Embora reconhecesse o valor do estabelecimento de relações entre as universidades, os serviços de saúde e a comunidade para a implantação de processos de mudança na educação dos profissionais de saúde, a proposta "NETWORK" privilegiava a construção de modelos orientados à comunidade 
("Community-oriented") e a adoção da metodologia da aprendizagem baseada em problemas ("problem based learning" - PBL).

No último Congresso da Network em Londrina, entretanto, a direção executiva da rede comunicou aos participantes sua decisão de unir-se ao programa Towards Unity for Health (que foi a única estratégia prática da proposta Changing que se concretizou).

Apesar de fundada em um país do Caribe, a presença da Network na América Latina só ganhou um pouco mais de expressão a partir da década de 90 , especialmente com a adesão dos projetos UNI.

Com a nova orientação, é de se esperar agora uma mudança nas ações e na composição da Network, que vai procurar atrair também participantes dos serviços de saúde e das entidades profissionais.

\subsection{CINAEM}

Também em 1991, outra iniciativa importante teve lugar no Brasil. Em resposta à proposta de se instituir um "exame de ordem" para a categoria médica (exame para avaliar os recém-formados, cujo resultado lhes permitiria ou não o exercício profissional), onze entidades ligadas ao ensino e à prática médicos instituíram a Comissão Interinstitucional de Avaliação do Ensino Médico (CINAEM, 2000); (GALLO, 1996).

As entidades percebiam a conexão existente entre a situação social e sanitária e a crise do modelo de educação médica vigente no país e rejeitavam o exame de ordem como uma alternativa consistente de superação dessa crise. Percebiam também a importância de uma iniciativa que partisse de instituições vinculadas à categoria médica, pois isso provavelmente ampliaria o espaço de adesão das escolas médicas às propostas eventualmente formuladas.

Não havia, entretanto, nenhuma proposta acabada. A primeira iniciativa da CINAEM foi a aplicação no Brasil de um questionário, originalmente elaborado 
pela OPS para se fazer um diagnóstico acerca da situação das escolas médicas latino-americanas. O questionário incluía questões sobre a estrutura política e econômico-administrativa das escolas, infra-estrutura, recursos humanos, modelo pedagógico, atividades de assistência e pesquisa e médico formando.

Setenta e oito das oitenta escolas brasileiras responderam a esse questionário, o que foi uma clara demonstração do interesse das escolas em integrar um processo de avaliação. Além de confirmar a evidência de que era insatisfatória a situação das escolas, os resultados desse questionário serviram a um exercício de delineamento ecológico que permitiu a seleção de três variáveis que deveriam ser estudadas nas próximas etapas do Projeto CINAEM: Recursos Humanos, Modelo Pedagógico e Médico Formando.

Seguiu-se um longo processo de construção de identidade da CINAEM e de suas relações com as escolas médicas. Foi constituída uma equipe técnica, encarregada de dar forma aos passos seguintes da avaliação. A negociação em torno da proposta apresentada levou quase três anos. Finalmente, em 1994, com o apoio efetivo dos projetos UNI, foi possível iniciar o processo de preparação da segunda fase do projeto (ASSOCIAÇÃO, 1993); (ASSOCIAÇÃO, 1994); (ASSOCIAÇÃO, 1995).

Foram desenhados três tipos de estudo para avaliar as variáveis selecionadas através da primeira fase. Para avaliar os Recursos Humanos foi proposto um estudo transversal .

Para avaliar o Médico Formando foi proposto um estudo longitudinal, que envolveria pelo menos dois testes cognitivos (antes e depois do internato) e avaliações periódicas de conhecimentos aplicados, habilidades e atitudes através da aplicação de uma Ficha Estruturada de Avaliação Prática durante as atividades do internato (PICCINI, 1996).

Para avaliar o modelo pedagógico adotado pelas escolas foi proposto um estudo desenhado a partir do enfoque estratégico: 
"O Instrumento de Avaliação Estratégica serve como catalisador da tematização sobre o modelo pedagógico das escolas médicas brasileiras - nas múltiplas e complexas relações que estabelece com a sociedade - e como tecnologia de operacionalização das decisões que emanam desse processo. Mas, para tanto, ele deve favorecer o envolvimento do conjunto dos atores sociais interessados na formação médica" (GALLO, 1996).

Por tudo isso, o projeto previa, como requisito básico para sua implantação nas escolas, a estruturação de Grupos Gestores Locais - cuja composição mínima requeria a participação de discentes, docentes, funcionários, entidades médicas e conselhos de saúde, além do aval participativo da direção de cada escola.

"O objetivo é propiciar um espaço policêntrico e representativo no qual, a partir da tematização de sua realidade os atores possam construir criticamente seu projeto local, ganhando autonomia e capacidade de gestão coletiva."

"A direcionalidade das propostas de mudança que devem surgir nesse processo não está dada a priori, embora os conteúdos valorativos do Instrumento de Avaliação Estratégica favoreçam propostas democratizantes e inovadoras pedagogicamente. $O$ caminho que cada escola seguirá será próprio, escolhido no embate entre os distintos projetos que forem propostos" (GALLO, 1996).

Interessante é que

"atores sociais normalmente excluidos dos processos de tematização - $e$ conseqüentemente das decisões - possam deles participar; além de incluir na agenda local temas que geralmente não são discutidos. Isso permite remover os véus instrumentais das relações estabelecidas entre os sujeitos sociais, potencializando sua capacidade comunicativa e abrindo possibilidades para a instituição de normas democráticas" (GALLO, 1996).

Na segunda fase, na prática, o trabalho realizado nas escolas restringiu-se aos estudos longitudinal e transversal. O trabalho de planejamento estratégico foi realizado somente através de oficinas (nacionais e regionais), sem repercussão prática na maior parte das escolas. Não houve, tampouco, a incorporação de outros atores externos às escolas e à corporação médica. 
Seguiu-se então uma terceira fase, constituída basicamente por oficinas de trabalho que procuraram estabelecer acordos a respeito do que seriam diretrizes centrais para uma proposta de mudança das escolas médicas, tais como o processo de formação, a docência médica, a gestão da escola médica e a avaliação. Foi produzido material conceitual que pretendia servir para orientar os processos nas escolas.

"O novo processo de formação deverá ser uma estrutura centrada na comunidade, com enfoque na pessoa e suas necessidades, pedagogicamente dividida em três momentos: compreensão, significação e intervenção.

Na primeira etapa, da compreensão, o estudante aprende a identificar $e$ compreender o objeto do trabalho médico, compreender o modo como são produzidas as necessidades num individuo biopsicossocial.

Os alunos seriam divididos em grupos de 8 e ficariam sob a orientação de um tutor. Nos primeiros 6 meses os alunos estudariam a dimensão psíquica do indivíduo: iriam para um ambulatório participar do atendimento a usuários e observariam como se manifestam suas necessidades. Identificadas as necessidades de fundo psíquico, estas passariam a ser material de pesquisa e reflexão para compreender como elas se produzem.

Nos seguintes 6 meses, os alunos, sob supervisão de outro tutor, passariam a estudar a dimensão social do objeto a partir da análise de manifestações individuais de necessidades de fundo social, em ambulatório, e da identificação de problemas de saúde coletiva em grupos populacionais. Identificadas as necessidades e os problemas, estes passariam a ser material de reflexão e pesquisa dos alunos, que buscariam as explicações para a produção de necessidades e problemas.

No segundo ano os alunos passariam a analisar a dimensão biológica do objeto, sob a supervisão de pelo menos dois outros tutores. Nesse momento, as manifestações de fundo biológico de pacientes, identificadas em ambulatórios e enfermarias, seriam tomadas como objeto de reflexão $e$ pesquisa pelos alunos, que fariam a descrição morfológica normal $e$ patológica e dos mecanismos fisiológicos e fisiopatológicos das principais afecções. 
Cada tutor contaria com o auxilio de outros docentes, médicos ou não, que seriam convidados a participar das discussões, tomando s dimensão em foco como elemento de integração transdisciplinar do ensino e do conhecimento. Pedagogicamente essa abordagem se daria mediante a utilização de um conjunto de técnicas que integraria as atividades práticas, de pesquisa e de ensino, exigindo do estudante uma participaçāo ativa no seu processo de ensino-aprendizagem.

Os campos de estágio seriam as unidades básicas de saúde, comunidades para a compreensão dos problemas coletivos e laboratórios, pondo o estudante em contato com o objeto de sua prática desde o início do curso.

Ao final desta etapa teríamos como produto a compreensão de como se produzem as necessidades, manifestações dos sujeitos, entendimento da conformação e funcionalidade biológica do indivíduo e incorporação crítica e consciente de métodos de construção do conhecimento, uma vez que para cada dimensão do objeto são indicados distintos métodos de análise.

$\mathrm{Na}$ segunda etapa os alunos seriam subdivididos em grupos de no máximo 5, que ficariam sob a orientação de um tutor diferente a cada 6 meses ou periodo correspondente a cada foco de formação. Nesta etapa aprendem a compreender as necessidades dos pacientes/sujeitos, identificam as alternativas tecnológicas de intervenção, aprendem a decidir e a executar intervenções nos processo de trabalho em saúde.

No primeiro momento dessa etapa, os alunos tomam as necessidades como manifestações integradoras dos interesses subjetivos de cura e alivio do sofrimento do sujeito/paciente como ponto de partida do trabalho médico. As necessidades referidas permitem aos alunos exercitarem técnicas semióticas, instrumentos de compreensão e significaçōes das manifestações biopsicossociais dos sujeitos. Seria o momento de identificar a origem da manifestação e desencadeante do tipo de estratégia de abordagem para o restabelecimento da normatividade do paciente.

Nessas atividades os alunos se apropriariam de técnicas semióticas da clínica, da psicanálise e de compreensão das representações sociais, para que possam identificar qual o cerme do problema do paciente. Esta identificação transcende a condição patológica, ou seja, o aluno além de estar capacitado 
para localizar uma lesão orgânica ou um distúrbio fisiológico, percebe um distúrbio de origem social ou psíquica, que acaba afetando a norma do paciente.

$\mathrm{Na}$ medida que o aluno vai se capacitando e incorporando saberes semióticos, amplia-se o foco da formação para o conhecimento das alternativas de intervenção nos campos psíquico, social e biológico e de complemento diagnóstico. $O$ conhecimento destes recursos gera a necessidade de decidir sobre sua utilização, ampliando mais uma vez o foco da formação. A última ampliação ocorre quando os alunos começam o treinamento para a realização de procedimentos.

Nesta etapa as atividades práticas ocorreriam em equipamentos assistenciais, comunidades, locais que oferecem risco coletivo, definidos a partir do foco de formação. A partir do momento que ocorre a última ampliação de foco, o treinamento pode se dar em qualquer nível de complexidade dos serviços de saúde.

Aqui também cada tutor contaria com o auxilio de outros docentes, médicos ou não, que seriam convidados a participar das discussões, tomando o foco como elemento de integração transdisciplinar do ensino e do conhecimento. Os tutores e os alunos seriam os gestores da agenda do curso médico. A viabilizaçño pedagógica se daria mediante a utilização de um conjunto de técnicas que integraria as atividades práticas, de pesquisa e de ensino, já utilizadas. Com isto, ao final dos 4 anos, o aluno teria o dominio da linguagem clínica, psicanalítica, das representações sociais; conhecimento das tecnologias diagnósticas e terapêuticas; capacitação para decidir a respeito de que tecnologia dispor para o restabelecimento da norma de determinado paciente; consolidação de habilidades e atitudes.

Essa proposta não é um novo modelo, mas uma simulação de como poderia se dar a formação de um outro médico. Esse exercício de construção de um novo processo de formação permitiu a visualização do funcionamento cotidiano de um novo software e consolidou o conceito de objeto da medicina, a organização da prática médica e o modelo de ensino como categorias centrais a serem consideradas para analisar o modo atual de 
formar médicos e as proposições de novos modelos de formação" (SANTOS, 2001).

Como preparação para a implementação dessas mudanças propõem a organização de disciplinas experimentais nas áreas de: ampliação da compreensão do processo saúde -doença ( $1^{\circ}$ ano); redefinição do instrumental da semiologia com a incorporação de instrumentos da saúde mental e da saúde coletiva ( $3^{\circ}$ ano); intervenção no processo saúde-doença ( $1^{\circ}$ ano); redefinição das etapas do processo de formação através de uma oficina nacional (CINAEM, 2000).

Propõem como metodologia para a elaboração dos pactos internos nas escolas a tolerância com o novo e o respeito pelos valores e práticas tradicionais. $O$ processo deveria ser orientado por resultados: as estruturas tradicionais que apresentassem bons resultados seriam preservadas e as que tivessem resultados inferiores aos das experiências inovadoras seriam substituídas (CINAEM, 2000).

Para a gestão transformadora, propõem uma atividade de capacitação do núcleo de educação e de dirigentes das escolas, feita pela equipe técnica, que teria como objetivos e elaboração de um novo projeto institucional, a gestão horizontal e participativa, o conhecimento e acesso a fontes e formas de captação financeira e a recuperação e ampliação da infraestrutura material (CINAEM, 2000). Seriam mantidas as atividades de avaliação nacional para monitoramento do processo.

$\mathrm{Na}$ quarta fase, atualmente em vigor, esperava-se que as escolas apresentassem projetos de transformação, que poderiam ser apoiados tecnicamente pela equipe de consultores constituída através da CINAEM. Até o momento, não se tem notícias a respeito de apresentação de qualquer proposta.

Nos últimos meses desencadeou-se uma crise dentro do colegiado da CINAEM, motivada pela disputa política entre o CFM e entidades médicas de um lado e DENEM, ABEM, CMB do outro, em razão de divergências na condução do processo. 


\subsubsection{Os UNI e a CINAEM}

A aproximação entre CINAEM e UNI existiu desde o início de ambas as iniciativas. Até mesmo porque elas foram gestadas na mesma época, ou seja, segundo semestre de 1990 e primeiro semestre de 1991. Em outubro de 1990, durante o XXX Congresso da ABEM, em Cuiabá, o recém- eleito presidente da ABEM começou a articular a CINAEM, que foi anunciada publicamente durante $o$ Congresso seguinte, em Campinas, em 1991. Ao mesmo tempo, a Fundação Kellogg realizava suas reuniões internas para definir as linhas gerais da proposta UNI, anunciada publicamente nos primeiros meses de 1991 através da cartaconsulta às universidades latino-americanas.

Por ocasião do Congresso de Campinas, por iniciativa do CCS/UEL, articulado com o CEBES, o presidente da ABEM e a presidente do Congresso, os UNI distribuíram um número especial da Revista de Educação Médica, na qual foi encartado um material sobre a iniciativa UNI - ainda em fase de anúncio e convocação.

Durante o I Forum Nacional de Avaliação do Ensino Médico, realizado concomitantemente ao XXXI Congresso, foi dado início ao processo de resposta, pelas escolas, do extenso questionário da Fase I do projeto da CINAEM. As escolas participantes da iniciativa UNI consideraram importante dar força a esse processo e ajudaram a quebrar determinadas resistencias existentes. Foi nesse contexto que o curso de medicina da UEL foi o primeiro a responder ao questionário e o fez de uma forma participativa, não burocrática.

Em 1992, por ocasião do XXXII Congresso da ABEM e II Forum de Avaliação do Ensino Médico, realizados em Londrina, deu-se continuidade ao processo de aproximação, embora os projetos UNI só tenham de fato iniciado suas atividades em novembro desse ano, com a realização do I Seminário Internacional dos Projetos UNI, em Londrina, logo após o Congresso da ABEM. 
$\mathrm{Na}$ fase II da CINAEM, os projetos UNI continuaram apoiando seu desenvolvimento, inclusive com recursos financeiros para que se realizassem as oficinas regionais, e também na elaboração do teste de avaliação cognitiva.

$\mathrm{Na}$ fase III foi negociado, com a intermediação dos UNI, um apoio financeiro da Fundação Kellogg à CINAEM para ajudar no financiamento das atividades previstas.

$\mathrm{Na}$ primeira e na segunda fases da CINAEM, os UNI se beneficiaram dos instrumentos de avaliação e dos espaços de discussão que foram abertos através da CINAEM dentro das escolas. Isso é verdade particularmente para Marília e Londrina.

A avaliação dos UNI, nesse momento, era que o movimento produzido pela CINAEM dentro das escolas era positivo e deveria ser apoiado. A avaliação se constituía em mais uma ferramenta para a mobilização dos professores, para a reflexão crítica sobre as práticas. Não era a única estratégia usada pelos UNI, mas somava.

A partir da III fase os projetos UNI passaram a discordar da direção dada ao projeto CINAEM , principamente em relação à tentativa de estabelecer um "comando central" para o movimento de mudanças que se buscava constituir e pela eleição da avaliação como ferramenta única de mobilização.

Depois do início da implantação das mudanças em Londrina e Marília, as ferramentas avaliativas propostas pela CINAEM não se aplicavam mais a essas realidades locais, porque eram elaborados de acordo com certa lógica de organização curricular e de opçõs pedagógicas.

Houve também, por parte da equipe técnica, um movimento de não reconhecimento dos processos de mudança de Marília e de Londrina aparentemente porque não se enquadravam na lógica de transformação proposta.

Apesar disso, os UNI continuaram participando, ainda que mais silenciosamente, do movimento. Representantes do UNI Marília integraram o corpo de consultores que trabalhou na construção de documentos de reflexão para 
a III fase da CINAEM, numa tentativa de contribuir para alargar horizontes e flexibilizar as metodologias propostas para a condução do processo - mas isso continuou não sendo possível.

\subsection{O Programa UNI}

Em 1991 a Fundação Kellogg lançou as bases de uma nova iniciativa na formação dos profissionais de saúde, o Programa UNI (KISIL \& CHAVES, 1994). A proposta partiu da avaliação crítica das experiências de Integração Docente Assistencial (IDA) na América Latina e pretendeu ir além do que já tinha sido possivel alcançar nas escolas, nos serviços e em sua relação com a comunidade (FEUERWERKER \& MARSIGLIA, 1996).

Por isso mesmo, o desafio ao desenvolvimento de um projeto de mudança foi lançado às escolas de saúde e não somente a cursos isolados; pressupunha-se, além disso, a articulação da universidade com os serviços de saúde e com a comunidade desde os momentos iniciais de elaboração das propostas.

Os modelos de serviço e os modelos pedagógicos poderiam apresentar variações de projeto para projeto, mas todos deveriam ter como denominador comum a base epidemiológica, a interdisciplinaridade, o trabalho em equipe multiprofissional e o ensino/aprendizagem em serviço.

A proposta considerava que a graduação deveria possibilitar o exercício competente da profissão em qualquer nível do sistema de saúde (primário, secundário e terciário). Daí a importância de chegar a uma definição clara do produto final dos cursos e das competências a serem buscadas, não somente ao nível da clínica, mas também no que se refere à pesquisa, à administração de serviços, à realização interpessoal com pacientes e outros membros de uma equipe de saúde.

Propôs-se que o conhecimento epidemiológico estivesse na base da seleção dos conteúdos temáticos, adotando como critério definidor a relevância dos temas a serem tratados na graduação. Recomendou-se combater a separação tradicional 
entre os ciclos básico e profissional, que favoreceria a interpretação de que a ciência é apenas pré-requisito e não parte integrante da Medicina Clínica. Propôsse incentivar a incorporação das ações clínicas de natureza preventiva e de promoção à saúde na atividade habitual dos profissionais.

As atividades inovadoras não deveriam estar restritas a um único departamento, nem a disciplinas como Saúde Coletiva, Medicina Preventiva, Epidemiologia, Ecologia (ROSA, 1994). Deveriam também, sempre que possível, ser atividades curriculares, regulares e obrigatórias, introduzidas ao longo de todo o curso. Isso seria indispensável para a interação de professores e alunos com os novos ambientes de ensino/aprendizagem, pesquisa e assistência.

Em relação à concepção pedagógica, considerou-se importante contemplar três aspectos: a diversificação dos locais de ensino/aprendizagem; o treinamento em serviço e as experiências de aprendizagem em equipes multiprofissionais. Ao longo de todo o curso, mas principalmente nas atividades práticas, deveria predominar a experiência de aprendizagem, isto é, a interação do aluno com o ambiente. $\mathrm{O}$ aluno aprenderia o que ele próprio faz ou descobre, não o que faz ou ensina o professor. O princípio da participação ativa dos alunos indicava como adequados, pedagogicamente, as metodologias ativas de ensino-aprendizagem e a participação dos alunos em projetos de investigação científica.

Outra característica da proposta pedagógica deveria ser a criação de experiências de aprendizagem para grupos de estudantes de diferentes carreiras, buscando produzir mudanças de atitude e o trabalho em equipe, compartilhado e interdependente.

Uma parte significativa do processo de formação deveria ocorrer nos postos e centros de saúde, ambulatórios e hospitais de nível secundário. A supervisão das experiências de aprendizagem nos serviços da comunidade poderia ser exercida por pessoal docente ou do próprio serviço.

O desinteresse da maioria dos professores pelas atividades dos serviços fora do hospital de ensino e o preconceito quanto à qualificação do pessoal desses 
serviços para o ensino seriam obstáculos a remover. Caberia à universidade, em conjunto com os serviços e a comunidade, construir programas de educação permanente e manter os profissionais atualizados, com o objetivo de preservar a qualidade dos serviços e a qualificação desses profissionais para o exercício das atribuições docentes que lhes fossem delegadas.

Propôs-se que fosse ampliado o campo da investigação científica, para incluir, além das pesquisas de caráter biomédico, aspectos epidemiológicos e sociais, perspectivas interdisciplinarares, buscando a preferência pelos problemas de saúde prioritários e pela organização e funcionamento dos serviços de saúde.

As falhas ou deficiências observadas na prestação de serviços assistenciais fora do hospital de ensino deveriam servir de base para a programação de educação permanente do pessoal dos serviços. Potencialmente também deveriam alimentar ajustes, revisões e reformas curriculares, já que muitas vezes as deficiências identificadas poderiam ser fruto da orientação da própria graduação.

Como se vê, não se trataria apenas de levar os estudantes para os serviços básicos de saúde ou para atividades "na comunidade", mas de incorporar o trabalho que neles se desenvolve aos objetivos e estratégias educacionais das escolas.

O sistema de avaliação educacional deveria estar voltado para verificar a competência e o desempenho, o que pediria mais do que memorização de conhecimentos; exigiria desenvolvimento de habilidades técnicas, atitudes e valores a serem incorporados ao longo da formação.

O programa também previa propostas de mudança para a comunidade (autocuidado, participação na gestão dos serviços, fortalecimento da cidadania, entre outros) e para o modelo de atenção à saúde - que não serão abordados neste momento.

Os projetos eram inicialmente 23, em onze países da América Latina. No Brasil havia seis deles: Botucatu, Brasília, Londrina, Marília, Natal e Salvador. As 
experiências continuam em andamento (com exceção do projeto da UnB), apesar de a maior parte dos projetos já ter encerrado o perído de financiamento.

Desde o início do UNI, além do apoio financeiro, foi ofereceido aos projetos um programa de apoio, que incluiu seminários, cooperação técnica com centros de educação de profissionais de saúde reconhecidos internacionalmente, oportunidades de viagens para conhecimento de outras experiências, avaliação etc.

Apesar de o financiamento aos projetos já estar encerrado, segue ativo o programa de apoio, previsto para durar até 2004. Essa forma de trabalhar potencializou os resultados, já que facilitou o desenvolvimento de redes, o intercâmbio de experiências e inclui uma atividade permanente de apoio estratégico aos projetos por parte da Fundação, possibilitando:

a) acompanhamento próximo do desenvolvimento dos projetos, tornando possível melhor compreensão acerca da construção dos processos de mudança institucional e de parceria

b) identificação de problemas e limitações das atividades de apoio desenvolvidas "à distância"

c) oferta de apoio técnico específico e apropriado a cada projeto ou a grupos de projetos no desenvolvimento de suas múltiplas dimensões

d) estímulo e instrumentalização dos projetos para sua articulação em rede, fortalecendo a construção de identidades comuns e a possibilidade de influenciar políticas

e) apoio aos projetos no trabalho de sistematização das experiências e na exploração de novas áreas como comunicação e avaliação.

\subsection{Breve síntese comparativa das propostas}

ALMEIDA (1999) fez um extenso estudo analítico a respeito das principais propostas de mudança da educação dos profissionais de saúde na América Latina. Apresento a seguir dois quadros (adaptados desse trabalho - pois eu incluí 
CINAEM e retirei a proposta da OPS de Gestão de Qualidade da Educação Médica) que sintetizam as principais características fundacionais das propostas, bem como as principais estratégias preconizadas por elas.

A Figura 2 apresenta as características fundacionais das propostas: 
Figura 2 - Características fundacionais das principais propostas de mudança da educação médica nos anos 90 .

\begin{tabular}{|c|c|c|c|c|}
\hline & UNI & TUFH & NETWORK & CINAEM \\
\hline Origem & América Latina & $\begin{array}{l}\text { Europa e América } \\
\text { do Norte }\end{array}$ & $\begin{array}{l}\text { Europa e América do } \\
\text { Norte }\end{array}$ & Brasil \\
\hline Área de Atuação & América Latina & Mundial & Mundial & Brasil \\
\hline Antecedentes Imediatos & $\begin{array}{l}\text { IDA, EMA, } \\
\text { Edimburgo } \\
1988 \\
\end{array}$ & Edimburgo 1988 & Alma-Ata 1978 & $\begin{array}{l}\text { Havana } 1991, \\
\text { Edimburgo } 1993\end{array}$ \\
\hline Promoção & $\begin{array}{l}\text { Fundação } \\
\text { Kellogg }\end{array}$ & OMS & Network & 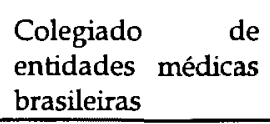 \\
\hline Financiamento & $\begin{array}{l}\text { Fundação } \\
\text { Kellogg }\end{array}$ & $\begin{array}{l}\text { OMS e Fundação } \\
\text { Kellogg }\end{array}$ & $\begin{array}{l}\text { Governo da Holanda, } \\
\text { Fundação Rockfeller, } \\
\text { Fundação Kellogg e OMS. }\end{array}$ & $\begin{array}{l}\text { Entidades médicas, } \\
\text { Fundação Kellogg }\end{array}$ \\
\hline $\begin{array}{l}\text { Principais } \quad \text { atores } \\
\text { institucionais }\end{array}$ & $\begin{array}{l}\text { Instituições } \\
\text { universitárias } \\
\text { da área de } \\
\text { saúde, órgãos } \\
\text { públicos de } \\
\text { serviços de } \\
\text { saúde, } \\
\text { organizações } \\
\text { comunitárias e } \\
\text { Fundação } \\
\text { Kellogg. } \\
\end{array}$ & $\begin{array}{l}\text { OMS, entidades } \\
\text { médicas, órgãos } \\
\text { públicos r e } \\
\text { privados de } \\
\text { serviços de saúde } \\
\text { e instituições } \\
\text { universitárias da } \\
\text { área de saúde }\end{array}$ & $\begin{array}{l}\text { Instituições } \\
\text { universitárias da área } \\
\text { de saúde, organizações } \\
\text { comunitárias } \\
\text { Network. }\end{array}$ & $\begin{array}{l}\text { Entidades } \\
\text { profissionais } \\
\text { médicas, escolas } \\
\text { médicas }\end{array}$ \\
\hline Principais sujeitos sociais & $\begin{array}{l}\text { Professores e } \\
\text { estudantes } \\
\text { universitários, } \\
\text { gestores dos } \\
\text { serviços de } \\
\text { saúde e líderes } \\
\text { comunitários } \\
\end{array}$ & $\begin{array}{l}\text { Professores } \\
\text { universitários e } \\
\text { profissionais dos } \\
\text { serviços de saúde }\end{array}$ & $\begin{array}{l}\text { Professores } \\
\text { estudantes } \\
\text { universitários, e líderes } \\
\text { comunitários }\end{array}$ & $\begin{array}{l}\text { Professores } \\
\text { universitários, } \\
\text { estudantes }\end{array}$ \\
\hline Situação atual & $\begin{array}{l}\text { Implantada, } \\
\text { com processos } \\
\text { em andamento } \\
\text { e resultados } \\
\text { parciais/interm } \\
\text { ediários }\end{array}$ & Em implantação & Em implantação & Em andamento \\
\hline
\end{tabular}

Fonte: ALMEIDA (1999), modificado

De acordo com ALMEIDA (1999), a análise relativa aos principais atores revela o predomínio de sujeitos do campo universitário, mas os serviços de saúde, a comunidade e as entidades profissionais também se fazem presentes. Todas as 
propostas, com maior ou menor grau de explicitação e aprofundamento, preconizam relações de parceria entre atores e sujeitos dos diversos campos.

A presença deste conceito - a parceria - traduzido, em sentido amplo, como alianças políticas com fins específicos, demonstra ser generalizado o entendimento de que as mudanças na educação médica, dependendo do seu plano de profundidade, implicam em mudança nas relações de poder, na correlação de forças políticas e em luta contra-hegemônica.

A Network reduz-se, na prática, a parcerias entre professores e alunos universitários. Apesar de imprescindíveis e potentes para atuar no terreno especifico das relações de ensino, isoladamente estas parcerias não têm força suficiente para ultrapassar os limites das inovações ou de processos de modernização das metodologias de ensino-aprendizagem. Na América Latina, particularmente, a ação da Network restringe-se à prestação de assistência técnica.

A proposta Towards Unity for Health preconiza parcerias entre atores/sujeitos do meio universitário, dos serviços de saúde e das entidades médicas e caracteriza a participação deste último parceiro como "estratégica". Cabem, aqui, algumas considerações a respeito, produzidas sem base em observações sobre práticas desenvolvidas, já que esta modalidade de parceria ainda não se concretizou em nosso continente.

Como já mencionado, as corporações profissionais cuidam prioritariamente, no caso dos seus vínculos com a formação médica, de exercer influências sobre os futuros novos membros, no sentido de garantir os interesses da profissão. As relações estabelecidas entre ideologia médica, modelo médico hegemônico e complexo médico-industrial, permitem estabelecer fortes interrogações acerca da eficácia desta estratégia de parceria.

A concepção de parceria mais consistente e que vem sendo implementada na prática é a existente na proposta UNI. As parcerias são constituídas por atores/sujeitos da área acadêmica dos cursos médicos e das outras profissões, por atores/sujeitos dos serviços de saúde, na maioria de abrangência local, e por 
atores/sujeitos das organizações comunitárias existentes nas áreas de atuação dos projetos.

Promovendo a atuação conjunta desses atores/sujeitos na condução política, na gerência e operação das ações desenvolvidas nos projetos UNI, a parceria vem propiciando o acúmulo de recursos de poder para o enfrentamento do modelo hegemônico da produção de médicos. Afinal, o modelo hegemônico, sem precisar de "parcerias", tem sido permanentemente realimentado pelo processo inercial conferido pelo seu próprio "status" de modelo consolidado e pela ação dos atores e sujeitos que o sustentam dentro e fora dos ambientes universitários.

No paradigma de comunicação construído por Jürgen Habermas, "o sujeito não é definido exclusivamente como sendo aquele que se relaciona com objetos para conhecê-los ou para agir através deles e dominá-los. Mas como aquele que durante o seu processo de desenvolvimento histórico, é obrigado a entender-se junto com outros sujeitos sobre o que pode significar o fato de conhecer objetos, agir através de objetos ou ainda dominar objetos ou coisas" (SIEBENEICHLER, 1989).

Os espaços coletivos de reflexão e ação propiciados pelos projetos conferiram aos sujeitos a possibilidade de se constituírem em sujeitos sociais e de moverem-se em direção à mudança em seus respectivos segmentos; possibilitaram a criação de outros níveis de atuação que dizem respeito ao coletivo e que se traduzem nos objetivos e ações comuns aos três segmentos. Um elemento fundamental para isso foi a quebra das barreiras de comunicação, o rompimento do isolamento habitual das instituições, e dos micro-espaços em seu interior, em relação à realidade social, além da construção de espaços coletivos de pensar, atuar e recriar.

A parceria possibilitou que se construíssem sujeitos ao criar oportunidades para que os diversos atores recuperassem a iniciativa em seus respectivos contextos, analisassem a realidade, falassem, propusessem, escutassem, tomassem decisões, executassem e avaliassem atividades / alternativas / projetos. 
O exercício de construir a parceria implicou democratizar as relações entre os segmentos e no interior de cada um deles. Em algum grau e em alguma medida isso aconteceu em todos os projetos UNI. Na parceria e através da parceria, os segmentos renovadores dos serviços, da academia e as parcelas progressistas da comunidade residente nas áreas de atuação dos projetos, têm interagido, ampliado seu grau de organização e aumentado sua capacidade de intervenção nos terrenos social, cultural e político.

São parcerias conflitivas, contraditórias em muitos momentos, o que é característico da natureza política dos processos de mudança social e organizacional, como ocorre em vários processos/projetos UNI.

Voltando aos sujeitos/atores identificados pelas propostas de mudança, merece registro o papel protagônico desempenhado pelos estudantes, tanto na proposta UNI, como na Network. Sem falar da sua atuação decisiva no Projeto CINAEM, como já mencionado. O seu deslocamento da condição de objeto de ensino para a de sujeito dos processos de aprendizagem vem resultando em processos que dão razão às análises de Juan César GARCĺA (1972). Novas relações técnicas e sociais entre os agentes de ensino são decisivas para promover mudanças nos processos de produção de médicos.

A figura 3 sintetiza as principais estratégias formuladas por cada uma das propostas de mudança: 
Figura 3 - Principais conceitos e instrumentos metodológicos concebidos pelas propostas de mudança da educação médica nos anos 90 e sua valoração.

\begin{tabular}{|c|c|c|c|c|}
\hline $\begin{array}{l}\text { CONCEITO } \quad(\mathrm{c}) \text { OU } \\
\text { METODOLOGGICO }(\mathrm{im})\end{array}$ & UNI & TUFH & NETWORK & CINAEM \\
\hline Articulação biologico-social (c) & ++ & - & - & ++ \\
\hline Avaliação como instru-mento de mudança (im) & ++ & + & - & ++ \\
\hline Capacitação pedagógica (im) & +++ & + & +++ & - \\
\hline Desenvolvimento da liderança (im) & +++ & ++ & ++ & + \\
\hline $\begin{array}{l}\text { Desenvolvimento integrado de modelos acadêmicos e } \\
\text { de modelos de atenção (im) }\end{array}$ & +++ & - & - & - \\
\hline Educação centrada no estudante (c) & +++ & - & +++ & - \\
\hline Educação orientada para a comunidade (c) & +++ & + & +++ & - \\
\hline Gestão estratégica (im) & ++ & - & - & ++ \\
\hline Interdisciplinaridade (c) & ++ & + & +++ & ++ \\
\hline Intersetorialidade (c) & ++ & + & + & ++ \\
\hline $\begin{array}{l}\text { Metodologias ativas de ensino-aprendizagem } \\
\text { (incluído o PBL) (im) }\end{array}$ & ++ & + & +++ & - \\
\hline Multiprofissionalismo (c) & +++ & - & + & - \\
\hline Pesquisa como instrumento de mudança (im) & - & +++ & + & - \\
\hline Planejamento estratégico (im) & ++ & + & - & +++ \\
\hline $\begin{array}{l}\text { Relaçōes entre prática, educação médica e estrutura } \\
\text { social (c) }\end{array}$ & ++ & + & + & +++ \\
\hline $\begin{array}{l}\text { Responsabilidade social da escola (equidade, qualidad } \\
\text { relevância, custo-efetividade)(c) }\end{array}$ & + & +++ & + & + \\
\hline
\end{tabular}
Fonte: Almeida (1999) modificado
(-) nenhuma importância;
(+) pouca importância; (++)

importância razoável; $(+++)$ muita importância

A valoração atribuída pelo autor a cada uma das estratégias foi baseada na ênfase com que cada uma é tratada pelas propostas. Não há uma estratégia preferencial, pois na prática ocorre a utilização de uma ou várias combinações de estratégias, com maior ou menor relevância dependendo do momento.

$\mathrm{O}$ autor considera que há indícios, levando em conta os processos e resultados observados, de que a parceria universidade-serviços-comunidade e o programa de apoio, no caso da proposta UNI, a ABP (aprendizagem baseada em problemas) e o trabalho em rede, no caso da proposta Network, se constituem nas estratégias que mais vêm gerando acumulação de recursos de poder entre os atores interessados nas mudanças (ALMEIDA, 1999). 
$O$ estudo de ALMEIDA (1999) identificou alguns resultados parciais/intermediários somente na esfera da proposta UNI, já que as demais propostas encontravam-se em estágio de implantação na América Latina.

Segundo o autor, os projetos UNI vêm gerando muitas inovações e algumas reformas no terreno acadêmico. Há alguns casos em que, através de intensos e extensos processos de conflito e de cooperação, o acúmulo de inovações e a alteração da correlação de forças vêm resultando na emergência de verdadeiras reformas nos modos de produção de médicos. São os casos de Marília e Londrina, em processo de desenvolvimento, que se caracterizam por alterações de processos e/ou de relações e/ou de conteúdos, com claros sinais de mudanças nas relações e nas estruturas de poder das suas esferas de atuação. Em estágio menos desenvolvido, também há mudanças significativas em Colima e Barranquilla.

Entre todas as propostas, o UNI é a única em que vem existindo um trabalho constante de revisão conceitual, de sistematização e de análise crítica das experiências. Essa característica tem possibilitado aos projetos e ao programa correções de rumo, atualização conceitual e a utilização de novas ferramentas estratégicas.

Um traço comum entre as propostas, exceto a CINAEM, é a identificação do cenário internacional como espaço importante de intervenção política. A participação em eventos nesse âmbito constitui-se em uma oportunidade de interação entre elas. Os UNI, na prática, revelaram-se mais permeáveis à incorporação de aspectos interessantes das outras propostas. 


\section{0 processo de mudança em Londrina}

\subsection{A cidade de Londrina}

Londrina é uma cidade jovem, que há 67 anos foi ponta-de-lança da colonização do Norte do Paraná. Criada pelos ingleses (a partir da construção da Ferrovia), foi povoada por imigrantes de mais de três dezenas de países de quatro continentes, mais migrantes do Brasil, especialmente do interior de São Paulo e de Minas - fugindo da decadência da cultura do café nessas regiões - e também do Nordeste - fugindo da seca (PELLEGRINI, 1998).

Cidade colonizada por gente em busca de vida nova na fértil terravermelha, tem sido marcada por pioneirismo em vários terrenos. Na reforma sanitária brasileira foi uma das cidades, juntamente com Campinas e Niterói, a inaugurar os serviços municipais de saúde no início dos anos 70. Mais recentemente, por conta da luta contra a corrupção e do "impeachment" do prefeito, lideranças londrinenses receberam, em Praga, o Prêmio Integridade 2001 (CÉSAR, 2001).

Segundo os dados do Censo de 2000, a cidade tem atualmente uma população de 446822 habitantes, 95\% da qual em área urbana. A área metropolitana, que envolve outros cinco municípios, tem 662789 habitantes.

A população economicamente ativa de Londrina é de 217306 habitantes e a de eleitores é de 299 309. Uma população que cresce $2,02 \%$ ao ano e já tem 7,5\% de idosos.

Inicialmente um pólo agrícola, maior produtor de café do país, Londrina transformou-se em um centro de serviços, já que o PIB municipal de US\$ $1,031,968,955,47$, tem $75,68 \%$ de sua origem nesse setor. A indústria (produtos alimentares, química, vestuário, calçados e tecidos) é responsável por outros $21,22 \%$ e a agropecuária por 3,1\% (soja, milho e bovinos).

A revista Exame, em sua edição de 12/12/01, trouxe a lista das 100 melhores cidades para se fazer negócio no Brasil, na qual Londrina ocupa a 17a. posição. 
Os critérios utilizados pela Simonsen Associados, responsável pelo trabalho, foram: para participar a cidade tem que ter mais de 95 mil habitantes (ou seja, estavam incluídos 234 dos 5.507 municípios brasileiros); tamanho de mercado; infraestrutura disponivel; facilidades operacionais como a proximidade de grandes mercados consumidores; qualidade de vida e tendência dos investimentos. $\mathrm{Na}$ sintonia fina constam itens como população e crescimento, distribuição de renda e classes sociais, potencial de consumo, educação e grau de escolaridade, saúde, estrutura empresarial, agropecuária, acesso a mercados, segurança entre outros, num total de 85 indicadores, com peso variável de acordo com a importância.

$\mathrm{Na}$ área da Educação, são 201 estabelecimentos de ensino fundamental com 73634 alunos; 53 estabelecimentos de ensino médio com 25335 alunos e 5 estabelecimentos de ensino superior com 21092 alunos. A taxa de analfabetismo em 1991 era de 10,8\% e havia 13392 jovens e adultos freqüentando cursos regulares (desde alfabetização até o nível médio).

$\mathrm{Na}$ área da Saúde, a cidade dispõe de uma rede de serviços públicos bem montada com 52 unidades básicas de saúde, dois hospitais gerais e uma maternidade. A universidade participa com um ambulatório de especialidades e com o hospital universitário (terciário). Há ainda outros hospitais privados, configurando um total de 1376 leitos. O SUS dispõe, portanto, de 2,39 leitos/1000 habitantes e no total, incluindo os serviços privados não conveniados, há 2,88 leitos por 1000 habitantes. Há 85 leitos de UTI e 20 leitos de UTI neonatal no SUS.

No momento atual estão sendo implantadas 90 equipes de saúde da família, cujo objetivo principal será reorganizar e ampliar a efetividade da atenção básica. 
A figura 4 ilustra a evolução da taxa de mortalidade infantil ao longo dos ultimos onze anos:

Figura 4 - Coeficiente de Mortalidade Infantil em Londrina de 1989 a 2000.

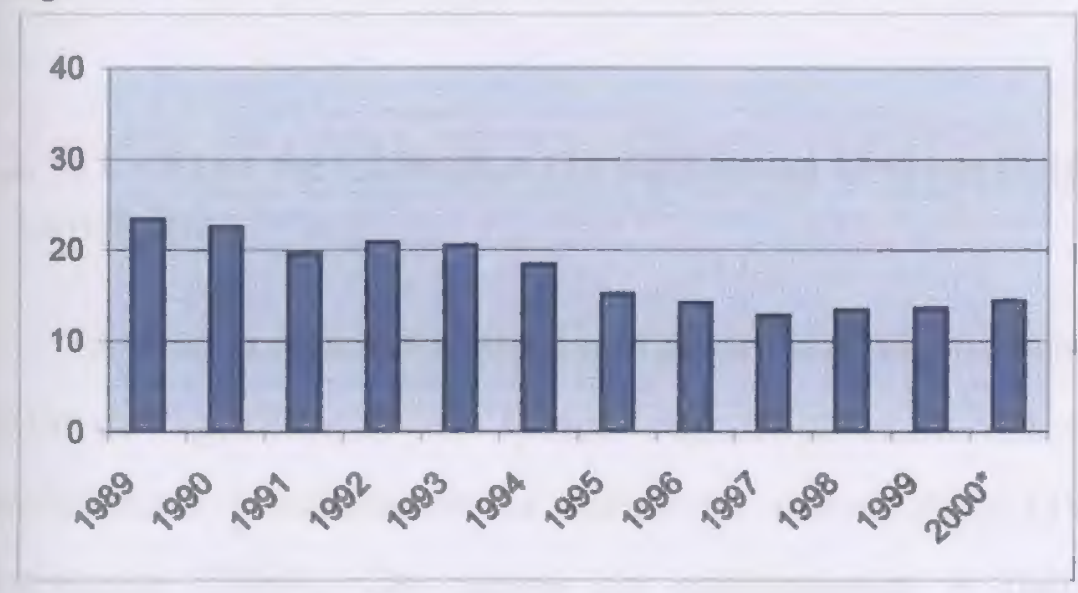

Fonte: Secretaria Municipal de Saúde de Londrina.

O perfil de mortalidade na cidade pode ser visto na figura 5:

Figura 5. Mortalidade proporcional em Londrina no ano 2000.

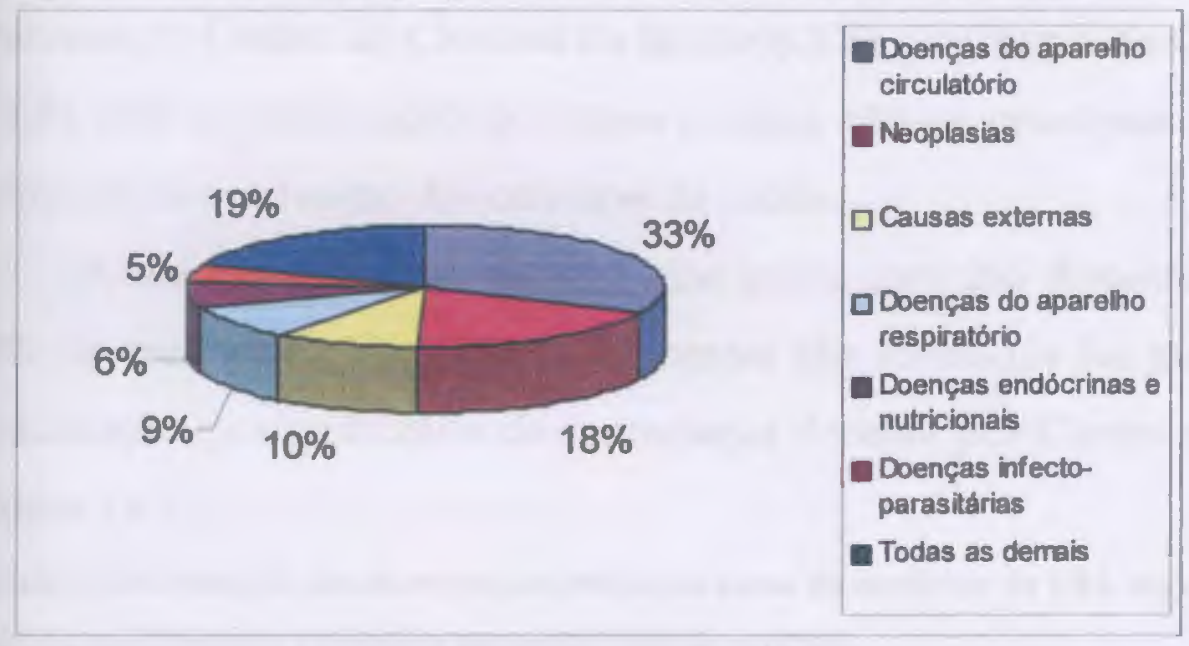

Fonte: Secretaria Municipal de Saúde de Londrina.

No ano 2000 , a taxa de mortalidade materna foi de 24,46 por 100000 nascidos vivos e as principais causas de internação hospitalar foram: tratamento em psiquiatria, diagnóstico ou primeiro atendimento em clínica médica, seguidas de parto normal e parto normal com atendimento de recém-nascido em sala de parto. 


\section{Concluindo o perfil}

Londrina, portanto, é uma cidade desenvolvida, inovadora e um importante pólo regional tanto em termos econômicos, como culturais e políticos. Seus indicadores de saúde revelam bom nível.

\subsection{O Centro de Ciências da Saúde da Universidade Estadual de Londrina}

A Universidade Estadual de Londrina (UEL) foi criada em janeiro de 1970 a partir da aglutinação de vários cursos já existentes. $\mathrm{Na}$ área da saúde já funcionavam previamente os cursos de odontologia (1962), medicina (1967) e bioquímica (1969). Os cursos de enfermagem e fisioterapia foram criados posteriormente, respectivamente em 1972 e 1979 (ITO, 1994).

A Universidade foi organizada em nove Centros de Estudos por áreas de conhecimento, de acordo com os princípios da Lei da Reforma Universitária brasileira. O Centro de Ciências da Saúde (CCS) e o Centro de Ciências Biológicas (CCB), com a colaboração de outros centros, são os principais responsáveis pela formação de graduação das carreiras da saúde.

Atualmente o curso de medicina conta com 266 docentes, $75 \%$ médicos e $23 \%$ da área biológica. $75 \%$ dos docentes são formados há mais de 15 anos. A qualificação e carga horária de contratação docente por Centro são mostradas nas tabelas 1 e 2.

Tabela 1. Distribuição dos docentes envolvidos no curso de medicina da UEL segundo grau de qualificação docente e segundo Centro em 2001.

\begin{tabular}{|l|l|l|l|l|l|}
\hline \multicolumn{2}{|c|}{ Graduação } & Especialização & Mestrado & Doutorado & Livre-docência \\
\hline CCB & 2 & 2 & 22 & 34 & 0 \\
\hline CCS & 19 & 64 & 68 & 49 & 1 \\
\hline CESA & 0 & 1 & 1 & 0 & 0 \\
\hline CCH & 0 & 0 & 1 & 1 & 0 \\
\hline CTU & 0 & 0 & 0 & 1 & 0 \\
\hline Total & 21 & 67 & 92 & 85 & 1 \\
\hline
\end{tabular}

Fonte: Planilha para Avaliação das Condições de Oferta pelo Ministério da Educação, (UNIVERSIDADE, 2001). 
Tabela 2. Distribuição dos docentes envolvidos no curso de medicina da UEL segundo carga horária e Centro em 2001.

\begin{tabular}{|l|l|l|l|l|}
\multicolumn{2}{|c|}{ Até $\mathbf{2 4}$ horas } & $\mathbf{2 5}$ a horas & $\mathbf{4 0}$ horas & Dedicação exclusiva \\
\hline CCB & 3 & 1 & $\mathbf{4}$ & 52 \\
\hline CCS & 128 & 3 & $\mathbf{4}$ & 34 \\
\hline CESA & 0 & 0 & 1 & 1 \\
\hline CCH & 0 & 0 & 0 & 2 \\
\hline CTU & 0 & 0 & 0 & 1 \\
\hline Total & 131 & 4 & 52 & 90 \\
\hline
\end{tabular}

Fonte: Planilha para Avaliação das Condições de Oferta pelo Ministério da Educação, (UNIVERSIDADE, 2001).

Na Avaliação das Condições de Oferta realizada pelo MEC a medicina da UEL foi avaliada como tendo "Condições Boas" (CB) em relação ao corpo docente e "Condições Muito Boas" (CMB) em relação às instalações e à organização didático-pedagógica.

No "Provão", os estudantes de Londrina foram A em 1999 e B em 2000 e 2001 (essas turmas são de transição; a primeira turma formada no novo currículo vai se formar em 2003).

Entre CCS, CCB e CCH são oferecidos 11 cursos de especialização, 32 programas de Residência Médica, 4 programas de mestrado (em saúde coletiva, em medicina e ciências da saúde, incluindo educação médica, em ciências biologicas e em microbiologia) e um programa de doutorado (em medicina e ciências da saúde).

As linhas de pesquisa registradas na Pró-reitoria de pós -graduação da UEL estão quantificadas na Figura 6:

Figura 6: Número de Linhas de Pesquisa por Área de Concentração desenvolvidas no curso de medicina e no CCB da UEL:

\begin{tabular}{|c|c|c|c|c|c|}
\hline & $\mathrm{CM}$ & $\mathrm{CC}$ & PALD & MISC & $\mathrm{CCB}$ \\
\hline $\begin{array}{l}\text { Áreas de } \\
\text { concentração }\end{array}$ & 3 & 12 & 14 & 5 & 4 \\
\hline $\begin{array}{ll}\text { Linhas } & \text { de } \\
\text { pesquisa } & \\
\end{array}$ & 31 & 22 & 25 & 10 & 75 \\
\hline $\begin{array}{l}\text { Area com maior } \\
\text { no. de linhas }\end{array}$ & $\begin{array}{l}\text { Ciências da } \\
\text { Saúde }\end{array}$ & Neurocirurgia & $\begin{array}{l}\text { Medicina/Anatomia } \\
\text { Patológica/ Patologia } \\
\text { Clínica }\end{array}$ & \begin{tabular}{|l} 
Saúde \\
Coletiva
\end{tabular} & $\begin{array}{l}\text { Ecologia } \\
\text { Genética }\end{array}$ \\
\hline
\end{tabular}

Fonte: CPG da UEL, website: www.uel.br. 
A produção científica no período de 1996 a 1998 levou à publicação de 64 artigos em revistas indexadas de circulação internacional, 190 artigos em revistas indexadas de circulação nacional, 7 livros, 119 capítulos de livros e 1016 resumos ou trabalhos completos em anais de Congressos Científicos ou Comunicações, Conferências, palestras etc em eventos científicos. Essa produção científica conferiu avaliação B ao curso de medicina da UEL na Avaliação das Condições de Oferta em 1999.

\subsubsection{Um pouco de história}

A então Faculdade de Medicina do Norte do Paraná foi criada em 1965 e começou a funcionar em 67, conformada por profissionais oriundos principalmente de São Paulo e do Rio de Janeiro, muitos dos quais "atraídos pela idéia de fazer uma escola nova, diferente, num clima menos hostil, menos conservador" (Entrevistado L1).

Por isso mesmo, ao longo dos anos 70 , no CCS, houve uma intensa participação, local e nacional, em torno de questões educacionais, especialmente no curso de medicina (GARANHANI et al, 1999). Nessa mesma época iniciava-se uma experiência conjunta da prefeitura e da universidade na área da Atenção Primária à Saúde e da Atenção à Saúde Famíliar, inclusive com apoio da Fundação Kellogg e da OPS. Eram iniciativas do setor de Saúde Comunitária, que envolviam a participação fundamentalmente dos estudantes de medicina do $4^{\circ}$. ano e a contribuição da universidade na capacitação dos profissionais e funcionários da saúde (ITO el al, 1994).

Nos anos 80, como em quase todos outros cursos de medicina do país, o debate educacional e o ímpeto por mudanças diminuíram (FEUERWERKER, 1998). Em toda parte, e também no Paraná, nesse período houve um crescimento importante dos serviços de saúde, especialmente através do Programa das Ações 
Integradas de Saúde (SOARES et al, 1996) e uma tendência dos atores da saúde coletiva/comunitária/pública das escolas a se voltarem mais para a mudança dos serviços que para a mudança da formação profissional (FEUERWERKER, 1998)

De acordo com o Entrevistado L1, esse também foi um período marcado pela inserção de parte do corpo docente da medicina na prática privada, que se expandia na cidade.

Destaca-se, além disso, o fato de que a existência de um colegiado único para todos os cursos havia levado à fragmentação do gerenciamento acadêmico, assumido na prática pelos departamentos, levando a que o CCS se tornasse uma estrutura administrativa intermediária, sem nenhuma importância na definição e implementação de políticas educacionais.

Apesar de todas essas dificuldades, houve duas reformas curriculares nesse periodo. Uma delas basicamente limitou-se a mudanças na grade horária. A outra teve como elemento substantivo a implantação do internato de dois anos no curso médico (GARANHANI et al, 1999).

No início dos anos 90 houve uma reviravolta na gestão da universidade e a retomada do debate acadêmico e da busca por inovações, incluindo a substituição do sistema de créditos pelo regime seriado e a criação de colegiados por cursos. No CCS, em processo marcado por intensas disputas, venceu as eleições uma chapa inovadora, composta por professores de tempo integral, encabeçada por um professor da saúde comunitária e, pela primeira vez, com uma enfermeira (e não um dentista) na vice-diretoria (GARANHANI et al,1999).

É unanimidade entre os entrevistados a referência ao dinamismo dessa gestão do CCS e ao papel fundamental que ela desempenhou em criar condições favoráveis às mudanças na formação profissional. Foram múltiplas as iniciativas no sentido de inserir o CCS no mapa da educação médica, dos movimentos por mudança na formação dos profissionais de saúde que aconteciam no país e no mundo. Primeira escola a aderir e responder ao primeiro questionário da CINAEM para diagnóstico da situação educação médica no país; sede do XXX Congresso da 
ABEM e do II Fórum Interinstitucional de Avaliação do Ensino Médico em 1992; escolhida como uma das escolas a participar do processo de Gestão de Qualidade promovido pela OPS, o caso de Londrina foi apresentado no Encontro de Educação Médica em Punta Del Este (CAMPOS, 1994); eleita Centro Colaborador da OMS em Educação e Práticas Médicas em 1995.

O debate educacional e a mobilização em torno da necessidade de mudanças na formação voltaram, então, com toda força à cena do CCS. Retomados o debate e também os conflitos, que se acirraram bastante com a intenção de adesão do CCS à proposta UNI, lançada pela Fundação Kellogg em 1991.

Oposição à mudança de perfil do médico formado; oposição à utilização de outros cenários de aprendizagem que não o hospital; desprezo pela parceria com os serviços públicos de saúde; disputa de poder, resistência à mudança "já que em time que está ganhando não se mexe e o CCS da UEL era reconhecido como de excelência" (o curso de medicina estava sempre entre os 10 melhores do país de acordo com o "ranking" da revista Playboy - que era o único referencial de avaliação dos cursos na época; os egressos da UEL também conseguiam boa taxa de aprovação nos concursos de Residência Médica - que era considerado outro critério indireto de qualidade). Esses eram alguns dos argumentos e conteúdos da oposição ao movimento de mudança que se estava instalando no CCS em 1991.

\subsection{O projeto UNI}

Foram dez longos meses de trabalho entre a pré-seleção e a aprovação final da proposta de Londrina pela Fundação Kellogg. Dez meses de debates, seminários, trabalhos em grupo, negociações entre parceiros, apoio de consultores; reuniões nos departamentos, com os alunos nos centros acadêmicos, com as comunidades nos bairros; debates e votações no Conselho Departamental e muitos outros momentos de estudo, análise e discussão. Nesse processo houve que vencer a mencionada resistência interna para conseguir a aprovação do projeto em todas 
as instâncias legais do CCS e, conseqüentemente, ter capital político para implementar a proposta.

Combinação delicada de estratégias foi necessária, pois, por um lado, somente o Núcleo de Estudos em Saúde Coletiva (NESCO) tinha acúmulo conceitual e técnico para sustentar a concepção e a elaboração da proposta e, por outro, era necessário, indispensável, o apoio e a participação dos outros setores e áreas do CCS no projeto.

A receita para esse período foi adotar um estilo radicalmente democrático, participativo e estratégico, que a direção do CCS da época assumiu com grande competência. Amplos espaços de debate e elaboração coletiva foram criados, possibilitando a participação ativa e efetiva de algo em torno de 140 pessoas na construção da proposta de trabalho, incluindo os estudantes como uma força importante (PROUNI, 1993). Foram também construídas alianças - e, portanto, compartilhado poder da Saúde Comunitária - com segmentos mudancistas da Clínica Médica, Cirúrgica, da Pediatria Social, dos cursos de enfermagem e de farmácia. Embora houvesse rearranjos posteriores, essas alianças foram fundamentais para assegurar governabilidade ao longo de todo o processo, incluindo a futura decisão sobre a reforma curricular da medicina.

Nesse momento inicial, apesar de incipiente, a parceria com os serviços de saúde e com os segmentos populares da região sul também contribuiu para fechar espaço, político e social, às resistências internas ao projeto UNI. (GARANHANI et al, 1999).

\subsubsection{A construção da parceria do ponto de vista político}

Como já mencionado, Londrina tinha uma história muito interessante e dinâmica na área da saúde. Após vários movimentos sucessivos de expansão, ao momento do início do projeto já existia uma rede municipal de serviços composta por 49 unidades básicas de saúde, dois hospitais gerais e uma maternidade. 13 
dessas unidades e um dos hospitais estavam situados na região sul de Londrina, área de atuação do projeto UNI.

Exceção feita a algumas áreas de invasão que ainda não contavam com infraestrutura básica, tratava-se já nesse momento de investir muito mais na qualificação da atenção que na expansão da rede. Aumentar a resolubilidade, melhorar a qualidade da atenção, construir vínculo e compromissos dos profissionais com a população e seus problemas e fortalecer as ações de promoção e prevenção eram ações que faziam parte desse repertório necessário (PROUNI, 1993).

Logo no início do processo - entre a fase de elaboração e o início da operação do projeto - houve mudanças na administração municipal, por conta das eleições. A primeira dentre as várias transições que o projeto teve que enfrentar (PROUNI, 1994).

Apesar de haver uma identidade muito grande de propósitos e objetivos entre a nova administração municipal (93 a 96) e o projeto UNI, diferenças e disputas políticas dificultaram as relações entre a universidade e os serviços de saúde.

No informe da direção do CCS ao seminário de autoavaliação do UNI Londrina, realizado ao final dos primeiros 12 meses de funcionamento do projeto, diz-se que:

"não há uniformização acerca da compreensão dos objetivos do projeto pelos parceiros; fizemos co-planejamento e estamos fazendo co-avaliação, mas onde ficou a co-programação e a co-execução?"

E mais adiante,

"enfim, de parceria estamos mal. Já estivemos melhor. Na nossa opinião, interesses político-partidários, eleitorais e a desconfiança em relação ao que o outro parceiro "no fundo" pretende com o projeto estão corroendo as bases de uma parceria que foi positiva e gratificante nos momentos de elaboração do projeto". (ALMEIDA \& VANUCCHI, 1993). 
Foram tomadas medidas radicais do ponto de vista da organização e funcionamento do projeto para superar essas dificuldades - alterando estruturas, reduzindo o número de subprojetos (que fragmentavam, ao invés de aumentar seu raio de ação), estabelecendo uma dinâmica efetiva de conversação, negociação e planejamento conjunto do trabalho prático, com resultados efetivos (PROUNI, 1994).

No segundo e no terceiro anos do projeto foi possível avançar nas ações cooperativas em torno da capacitação de gestores, da territorialização e do fortalecimento dos conselhos de saúde (PROUNI, 1995).

A comunidade da região sul, em 1991, recém havia iniciado seu processo de organização independente através da realização da $1^{\text {a }}$. Conferência Regional de Saúde e da criação do CONSUL (Conselho Popular de Saúde da Região Sul).

A região incluía área urbana e rural (esta última congregando $30 \%$ da população de 96000 habitantes), com deficiências importantes de infraestrutura em alguns locais, especialmente os mais recentemente ocupados. Uma forte organização de base - principalmente através de Associações de Moradores e de Mulheres - garantiu uma importante capacidade de mobilização e conquista, que foi fundamental para o fortalecimento das organizações comunitárias.

No início do processo, no entanto, havia ainda dificuldades importantes para superar as diferenças políticas e partidárias entre os vários segmentos comunitários, dificultando as ações conjuntas e a participação articulada da comunidade nas instâncias do projeto.

Depois de um momento inicial de turbulências, o segmento comunidade foi o que melhor soube aproveitar as oportunidades do projeto para fortalecer sua organização própria, as relações e as ações em parceria e sua capacidade de intervenção política na cidade (PROUNI, 1994) (PROUNI, 1996) (TURINI et al, 1999).

Ainda no final de 1994, houve uma importante transição política dentro do CCS, quando assumiu a direção do Centro e do Projeto UNI - em eleição com 
chapa única - um professor da Clínica Médica, inicialmente opositor do projeto e das propostas de mudança, mas depois convencido e convertido a participante ativo. Consubstanciava-se, assim, uma aliança, dos setores mudancistas previamente articulados com novos segmentos da clínica médica, o que seria imprescindível para viabilizar as mudanças acadêmicas, especialmente no curso de medicina.

Como já mencionado, não foi fácil construir a parceria e encontrar o caminho da cooperação, da gestão compartida, superando a mera repartição de recursos e a justaposição de estratégias no funcionamento do projeto UNI em Londrina. Isso só se tornou possível através do enfrentamento conjunto dos problemas prioritários identificados pelas comunidades nas áreas de abrangência das unidades de saúde.

A capacitação em torno dos mais variados temas e necessidades foi também uma estratégia decisiva para diminuir diferenças, criar possibilidades de cooperação e atenuar divergências entre os três parceiros.

O momento "áureo" de operação da primeira fase do projeto, sob nova gestão, foi justamente seu terceiro ano, ao longo do qual também ocorreu, de maneira bastante participativa - em seminários que contaram com 150 pessoas processando as contribuições de tantas outros participantes dos vários grupos de trabalho - a elaboração da proposta de trabalho para a segunda fase do projeto UNI (PROUNI, 1996).

Logo no início desse novo período (97 a 2000), houve uma nova transição do poder público municipal, que dificultou muito o trabalho conjunto. A relação de parceria que sustentou o projeto nessa época foi fundamentalmente entre universidade e comunidade, que juntas buscaram estratégias para manutenção dos espaços de cooperação nos serviços de saúde e para superação da intransigência e da pobreza das propostas políticas da secretaria municipal de saúde de então.

Especialmente a partir de 1998, apesar de os processos inovadores e de parceria terem sido largamente incorporados na dinâmica institucional regular dos 
participantes (fruto das estratégias adotadas e da força acumulada na primeira fase) e apesar de continuarem sendo produzidos processos interessantes e resultados significativos, a estrutura do projeto UNI em si deixou de ser usada estrategicamente.

Poucos foram os espaços amplos de debate propiciados - e quando ocorreram foi sempre por pressão "externa" do programa, como quando do seminário de sistematização (PROUNI, 1999). Predominaram as estratégias de resistência e de acumulação de forças "no miúdo", nas tarefas cotidianas do trabalho de estudantes e docentes junto às unidades de saúde e ao trabalho da comunidade nas áreas de abrangência, mesmo quando havia possibilidades de fazer diferente e de ousar.

Deixou de haver também, em conseqüência, o processo de reflexão sistemática e coletiva a respeito dos processos desencadeados. A avaliação e a reflexão crítica passaram a ser realizadas em grupos menores e em outros espaços - proprios de cada segmento ou curso.

Não se pode, no entanto, subestimar a força e a dinamicidade dos processos já instalados no interior de cada segmento, especialmente em setores da academia e na comunidade, e na relação sinérgica entre os três. Ou seja, apesar de a nova coordenação do projeto UNI não trabalhar como direção estratégica dos processos, eles continuaram existindo, ativos, muito ativos, transformadores e acumulando poderes, só que para outros atores.

No momento atual, depois de uma nova mudança na gestão municipal com o retorno do secretário e de parte da equipe que havia estado em cena em boa parte da primeira fase do projeto UNI - há novamente um cenário mais favorável à parceria com os serviços de saúde, especialmente em torno da educação permanente, da implantação da saúde da família e do fortalecimento do controle social na esfera da atenção básica. Falta muito, no entanto, em relação à integração efetiva dos serviços universitários (hospital terciário e ambulatório de especialidades) com a rede municipal de serviços de saúde. 


\subsubsection{A construção da parceria na prática}

Rapidamente se percebeu que para além das intenções e dos entendimentos políticos (indispensáveis para iniciar o processo) a parceria somente se construía efetivamente na prática através da realização de projetos conjuntos e particularmente através do enfrentamento de problemas da realidade que exigissem a articulação dos parceiros para serem enfrentados.

Percebeu-se também que havia três níveis de construção de relações de cooperação: o político-institucional (analisado no capítulo anterior), o da gestão e o operativo. O nível de gestão envolve a coordenação do projeto e está encarregado de traçar as diretrizes da ação e a destinação de recursos: ou seja, a esse nível se definem temáticas de trabalho, por exemplo, educação permanente, apoio à gestão local das unidades, fortalecimento dos conselhos de saúde etc e como se distribuirão os recursos para realizá-las. Mas é no nível operativo que se constrói a parceria na prática; que se constroem compromissos entre pessoas e que se processam as mudanças mais significativas.

No início do projeto foram atendidas algumas necessidades materiais dos parceiros tais como, ampliação da biblioteca do CCS, aquisição de computadores, ampliação física e equipamento de unidades de saúde, aquisição e equipamento da sede do CONSUL, aquisição de veículos utilizados para o deslocamento de estudantes, docentes, profissionais dos serviços e da comunidade em seu trabalho cotidiano.

Ainda nos primeiros anos, foram desenvolvidos em conjunto, pela universidade e pelos serviços, processos de capacitação gerencial dos dirigentes das unidades e dos futuros distritos de saúde, um sistema de geoprocessamento e a informatização das unidades de saúde. 
Com a participação dos três parceiros foi realizado o trabalho de territorialização das unidades de saúde, possibilitando a identificação de recursos locais e também dos problemas prioritários. Muitas vezes foram justamente esses problemas prioritários que serviram como tema para a ação prática dos estudantes na comunidade e nas unidades de saúde.

Através de várias estratégias - que serão discutidas um pouco mais adiante - houve forte estímulo para o trabalho de docentes e estudantes em parceria com os profissionais dos serviços e com a comunidade. Uma parte dessas ações se concretizava e se concretiza nos espaços curriculares de trabalho nesses cenários e outra se concretizava e concretiza através da articulação independente entre os parceiros.

Há uma multiplicidade de temas e de produtos, desde a capacitação de conselheiros de saúde, o desenvolvimento de material instrucional sobre temas relevantes como adolescência e sexualidade, gravidez na adolescência, reorganização do funcionamento de determinadas unidades, desenvolvimento de metodologias para trabalho com grupos de gestantes e hipertensos, evento sentinela, capacitação dos profissionais dos serviços em temas de seu interesse etc (SEMINA, 1996); (SEMINA, 1997); (ITO, 1996).

Uma iniciativa de grande impacto nas relações de cooperação na base do sistema foi a implantação do internato de enfermagem em 1995. A idéia do internato surgiu do Colegiado de Enfermagem, mas a construção da proposta foi feita em conjunto entre academia e serviços. Várias oficinas de trabalho envolvendo docentes e profissionais dos serviços foram realizadas para definir objetivos do internato, competências do interno, atividades a serem desenvolvidas, metodologias de avaliação. Também foi conjunta a eleição das unidades em que o internato se concretizaria (VANUCHI et al, 1996).

No último ano do curso, os estudantes permanecem 10 semanas consecutivas em unidades básicas de saúde e outras 10 semanas no hospital. Durante essas 10 semanas os estudantes ficam trabalhando em conjunto e sob a 
orientação direta dos profissionais dos serviços e há uma supervisão periódica (semanal ou quinzenal, dependendo da necessidade) pelos docentes.

$\mathrm{Na}$ avaliação realizada no final do primeiro ano, chegou-se à conclusão de que:

"a experiência foi de muita importância para que os acadêmicos valorizassem e interação entre o aspecto social e o biológico do indivíduo, facilitando a compreensão do processo saúde-doença em suas dimensões individual e coletiva." (AROCENO et al, 1996).

A resistência inicial dos profissionais dos serviços foi totalmente dissipada, sendo que o internato começou a ser reivindicado pelas unidades que ainda não o estavam recebendo. Isso porque

"a presença do interno acabou contribuindo para o trabalho desenvolvido na UBS.... interno de Enfermagem demonstrou empenho e iniciativa em desenvolver açōes de enfermagem que contribuem com a vida da UBS e com a melhoria da atenção prestada à população, buscando suprir necessidades dos locais de trabalho em que foram realizados os estágios e, em concomitância, melhorando sua formação profissional" (AROCENO et al, 1996) .

No início da segunda fase do projeto, quando se iniciou o período de maiores dificuldades políticas nas relações com a secretaria de saúde, foi adotada a estratégia de intensificar as relações e o trabalho com as instâncias médias da secretaria e com os profissionais nas unidades de saúde.

Nessa época, foi desencadeado um processo de "Educação Permanente em Saúde", com o objetivo de buscar maior eficácia no trabalho do enfermeiro enquanto coordenador do processo de trabalho da equipe da UBS e de desenvolver uma nova tecnologia de trabalho para o Setor de Desenvolvimento de Recursos Humanos /Oficina de Saúde Pública da Autarquia Municipal de Saúde. Esse trabalho teve 18 meses de duração e foi realizado através de oficinas mensais (PROUNI, 2000). 
A partir de 1999 começou a ser realizado anualmente um Simpósio de Experiências e Pesquisas Integradas Ensino, Serviços e Comunidade, uma promoção conjunta da universidade, da secretaria de saúde e do CONSUL. Os critérios para aceitação dos trabalhos são: 1. ser desenvolvido, em sua maior parte, no ano da apresentação e 2. envolver, no mínimo, duas parcerias entre cursos do CCS/UEL, profissionais da rede de serviços e comunidade. Na primeira versão do Simpósio foram apresentados 106 trabalhos; na segunda, 93. A temática dos trabalhos pode ser assim categorizada: Atendimento Domiciliar, Biossegurança, Doenças Crônico-Degenerativas, Educação em Saúde; Educação em Serviços, Ensino; PEEPIN, Estudos Epidemiológicos; Organização Institucional, Saúde Bucal; Saúde da Criança; Saúde da Família; Saúde Mental; Saúde da Mulher; Saúde do Trabalhador.

Os trabalhos em geral trazem uma reflexão sobre o trabalho cotidiano nos vários serviços; vários deles apontam caminhos para melhorias substanciais nas unidades, passíveis de implantação imediata. A maioria integra ensino e pesquisa, em ambientes como: domicílios, conselhos, territórios das UBS, e internos às UBS, a ambulatórios e enfermarias de hospitais e todos foram desenvolvidos em disciplinas curriculares (UNIVERSIDADE, 2000).

A partir do ano 2000, por decisão dos colegiados de curso, a recepção aos calouros do CCS passou a ser feita em parceria com os serviços e a comunidade. Após uma breve sessão na universidade, os estudantes são divididos em grupo e deslocados para as várias unidades de saúde da cidade. Lá eles são recebidos pelas equipes das unidades e por representantes das comunidades, que se encarregam de levá-los a conhecer a área e a explicar a dinâmica da saúde na região.

A comunidade da região sul de Londrina é exemplo em todo o país em relação à sua capacidade de organização e de pressão política. Além de cuidarem de sua organização própria (conselhos de saúde em todas as unidades, conselho popular de saúde com forte base, participação ativa em todas as áreas de interesse da comunidade, representação no Conselho Municipal e no Conselho Estadual de 
Saúde, presidência do Conselho Municipal da Mulher etc.), são extremamente criativos na proposição de temas para o trabalho conjunto, na construção de parcerias nos espaços locais e na mobilização dos parceiros em torno das questões prioritárias. (PROUNI, 1996); (PROUNI, 1998); (TURINI et al, 1999); (CONSELHO, 2000).

Há um projeto comunitário chamado Biblioteca Virtual que busca a apropriação pela comunidade das novas tecnologias de informação. Um dos subprojetos aí trabalhados é o da Sala de Situações. Originalmente concebido para possibilitar que a comunidade se apropriasse das informações de saúde para estabelecer suas prioridades de ação, a iniciativa foi encampada também pelo CCS e pela Secretaria Municipal de Saúde. Atualmente a coleta, o processamento e a análise dos dados são feitos de maneira articulada por estudantes, representantes das comunidades, agentes comunitários e outros profissionais dos serviços. Essa base de dados tem sido usada para eleger os problemas prioritários a serem enfrentados em parceria (PROUNI, 2000).

Apesar de o trabalho dos três segmentos e das relações de parceria serem indissociáveis, didaticamente vou me concentrar agora na análise das estratégias desenvolvidas para a transformação do componente acadêmico - claro, sempre que necessário fazendo referência à parceria e aos dois parceiros.

\subsection{O trabalho no segmento acadêmico}

\subsubsection{A fase inicial}

A proposta do programa UNI para a academia estava sintonizada com o movimento mundial de educação médica. Era pertinente, porém um tanto vaga. Defendia-se a busca de maior relevância social, a formação orientada por competências, a interdisciplinaridade para a articulação dos conteúdos relevantes, para a investigação e abordagem mais eficiente dos problemas de saúde, a 
utilização de metodologias ativas de ensino-aprendizagem, o trabalho dos estudantes nos cenários reais desde o início da carreira.

Esses elementos, apesar de genéricos, foram suficientes para que se delineasse um perfil de ação e também constituíram desafio bastante, pois não havia, entre os participantes do projeto, clareza conceitual e nem acumulação prática em torno de vários deles, tais como a interdisciplinaridade e as metodologias ativas de participação (GARANHANI et al, 1999).

Em 1994, o projeto UNI de Londrina defendia a necessidade de desenvolver um novo modelo acadêmico, que teria como princípios (ITO, 1994):

- a articulação academia-serviços-comunidade

- interdisciplinaridade

- ação em equipe multiprofissional

- ensino e pesquisa orientados pelos problemas prioritários da população

- formação orientada para a integralidade atenção à saúde

- articulação do ensino, pesquisa e assistência

- integração do conhecimento e do ensino das disciplinas básicas e clínicas ou profissionalizantes

- inserção precoce dos alunos nos serviços de saúde e no trabalho comunitário

- problematização como metodologia inovadora de ensino em substituição às aulas expositivas

- enfoque tutorial nas relações professor-aluno

- uso de tecnologia apropriada

- educação continuada como compromisso da universidade

Apesar das limitações, hoje evidentes, dessa formulação, havia clareza de que o processo de mudança para atingir esses objetivos teria necessariamente que ser participativo e envolver ativamente estudantes e professores em sua construção (ALMEIDA, 1993). 
Coerentemente, as primeiras estratégias desenvolvidas pelo UNI Londrina tinham como objetivo abrir espaço para que estudantes e professores pudessem explorar os campos da interdisciplinaridade, da ação sobre problemas da realidade, da parceria com os serviços de saúde e a comunidade, das metodologias ativas de aprendizagem, do trabalho em pequenos grupos.

A figura 7 ilustra o conjunto de estratégias utilizadas para o desenvolvimento do segmento academia:

Figura 7 - As estratégias para mudança utilizadas no componente acadêmico do Projeto UNI Londrina de 1993 a 2000.

\section{ESTRATÉGIAS UTILIZADAS}

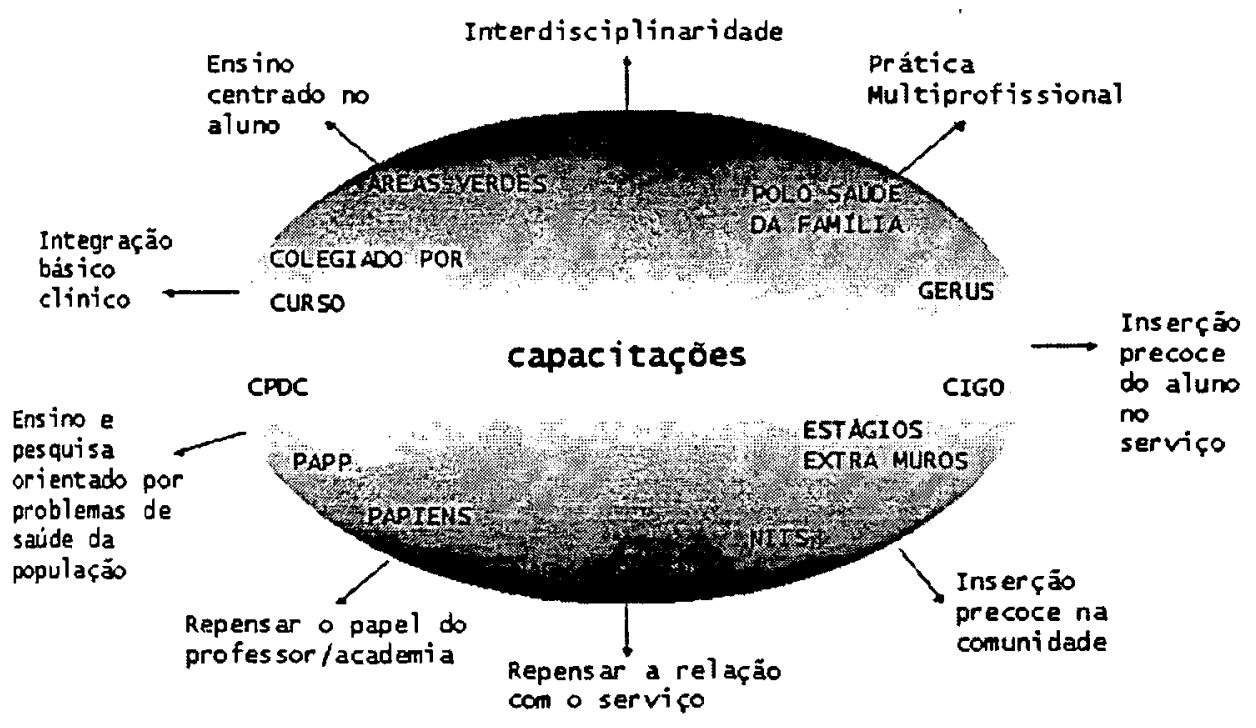

Fonte: Apresentação no seminário do componente acadêmico dos projetos UNI. (CAMPOS \& BADUY, 2000).

A primeira dessas estratégias se chamava PEEPIN (projeto especial de ensino: assistência primária à saúde, práticas multiprofissionais e interdisciplinares). Começou como um projeto especial, portanto uma atividade optativa, mas que foi tornado, ao longo do tempo, curricular, pois passou a ser considerado como carga horária necessária para a integralização do currículo 
pleno - uma estratégia eficaz de institucionalização da iniciativa (SOARES et al, 1996).

Esse projeto era oferecido para todos os alunos do primeiro ano das cinco carreiras da saúde e desenvolvido nas unidades básicas de saúde e nos espaços comunitários de suas respectivas áreas de abrangência. Havia uma primeira etapa de reconhecimento da área, a identificação de problemas, definição conjunta com os serviços e a comunidade sobre quais os temas prioritários a serem abordados.

Depois de uma fase de exploração teórica para a compreensão do problema escolhido, os estudantes partiam para a ação em direção à sua solução. A metodologia utilizada era a problematização, resgatada do Projeto Larga Escala, para capacitação de adultos - atendentes de enfermagem - em seu aperfeiçoamento a auxiliares de enfermagem (UNIVERSIDADE, 1992). Segundo ITO et al (1997a),

"A metodologia da problematização se propõe a viabilizar a interação entre o sujeito e o objeto no ambiente de trabalho, considerando as formas de aprender do sujeito e recortes do objeto que permitem a ele partir de seu referencial de percepção da realidade, sem negar seus conhecimentos de prática e senso comum, para construir novos conhecimentos elaborados $e$ especificos, de acordo com a habilitação profissional. O sujeito tem voz $e$ constrói ativamente o conhecimento; o instrutor coloca-se como coadjuvante que organiza o caminho e facilita esta construção".

E mais adiante:

"Trabalhar coma metodologia da problematização implica inserir-se na comunidade e trabalhar com ela na resolução de problemas demandados pela comunidade e pelos serviços de saúde. Dessa forma se estabelece uma relação de compromisso ético com a realidade social".

Uma metodologia, portanto, criada para a educação de adultos no e para o trabalho, sendo utilizada para a formação de profissionais de saúde na e para a realidade. 
De uma participação inicial de 50\% dos estudantes em 1992, o PEEPIN chegou a 1996 com participação estudantil de $90 \%$. Tornou-se depois atividade obrigatória nos novos currículos de medicina e de enfermagem e segue sendo sustentado como projeto pelas outras carreiras da saúde.

O corpo docente que se encarregava das atividades era oriundo de todos os departamentos e centros envolvidos com os cursos da saúde. Havia um significativo momento de capacitação pedagógica e acompanhamento do trabalho destes docentes no campo. Houve progressivamente uma importante participação de docentes das áreas básicas, além do setor de saúde comunitária nos trabalhos do PEEPIN.

Foi consenso entre todos os entrevistados (L1, L2, L3, L4, L5) a importância que o PEEPIN teve, junto a estudantes e professores, em relação a mostrar a possibilidade de trabalhar de maneira interdisciplinar, de utilizar metodologias ativas, de conhecer melhor o espaço dos serviços e da comunidade.

Na prática o PEEPIN, para os docentes, foi um grande disparador da reflexão crítica sobre as práticas tradicionais e uma oportunidade real de construir propostas alternativas. Foi também uma modalidade muito eficiente de capacitação pedagógica com uma orientação construtivista, uma experiência de produção conjunta e não de transmissão do conhecimento (ITO et al, 1997b)

Cumpriram papel semelhante, embora não tão amplo quanto o PEEPIN, outros dois projetos especiais, um na área de investigação (PAPP - programa de apoio a projetos de pesquisa) e outro na área do ensino (PAPIENS - programa de apoio a projetos de integração de ensino com os serviços de saúde).

O PAPP era um projeto de estímulo ao desenvolvimento de pesquisas aplicadas, realizadas em parceria com a comunidade ou com os serviços de saúde havia a possibilidade de auxílio financeiro para a realização das pesquisas que fossem pertinentes. O PAPIENS estimulava a criação de projetos interdisciplinares de ensino em parceria com os serviços, buscando assim oferecer oportunidades aos 
professores de experimentarem e construírem a interdisciplinaridade na abordagem de conteúdos relevantes (SOARES et al, 1996).

Ao desenvolverem trabalhos de pesquisa em equipes multiprofissionais, com a participação de estudantes, docentes, profissionais dos serviços e membros da comunidade consideravam estar "estimulando a transdisciplinaridade e favorecendo um enfoque complexo na investigação da realidade". Era um caminho para a construção da relevância social da universidade, da produção de conhecimentos sobre problemas prioritários (ITO et al, 1997b).

Outra estratégia significativa no período inicial foi a das Áreas Verdes, elaborada a partir de debates com o Núcleo de Tecnologia Educacional em Saúde (NUTES) da Universidade Federal do Rio de Janeiro. Em 1994, em função de articulação da direção do projeto UNI com o Conselho Deliberativo do CCS e com o Conselho de Ensino e Pesquisa, a universidade decidiu ampliar o ano letivo de 17 para 19 semanas e no CCS decidiu-se aproveitar o saldo de dias letivos para oferecer aos alunos atividades de preferência interdisciplinares ou multiprofissionais, abordando aspectos que raramente seriam desenvolvidos em disciplinas isoladas. Essas atividades eram distribuídas ao longo do período letivo.

Na prática, esse programa foi essencial para ajudar a ultrapassar o obstáculo da falta de tempo disponível nos currículos tradicionais para articular atividades interdisciplinares e multiprofissionais, organizadas às vezes conjuntamente pelos colegiados dos diferentes cursos, incluindo também atividades culturais e humanísticas.

Outra estratégia desenvolvida nessa primeira fase foi a criação do NAP (Núcleo de Apoio Pedagógico) com o objetivo de tornar disponíveis aos docentes do CCS um suporte conceitual e operativo no terreno das questões metodológicas e pedagógicas. O NAP cumpriu em parte esse papel, principalmente junto aos segmentos de docentes mais mobilizados, mas muitos outros recursos - externos foram necessários para a ampla capacitação pedagógica dos docentes. 
Uma última estratégia, que teve como objetivo interessar os docentes da área clínica, foi a capacitação em epidemiologia clínica. Vários cursos, oportunidades de formação fora da UEL e convênios de cooperação foram colocados em prática. Como resultado há um bom grupo de docentes qualificados e capazes de contribuir na prática da leitura crítica e do desenvolvimento de investigações. No entanto, houve baixa penetração da estratégia na área clínica.

\subsubsection{Colhendo frutos}

Um balanço parcial, feito em 1996 (SOARES et al, 1996), revela a importância da participação nos quatro projetos. Começando pelo das Áreas Verdes, foram realizadas atividades em 8 dias letivos em 1994, 12 dias em 1995 e 5 dias em 1996, num total de 19 tipos diferentes de atividades (desde uma série de cinema e debates, passando por um curso de atendimento ao trauma, debates sobre a reforma curricular de enfermagem e visitas a outros centros de interesse), que envolveram a participação de 2095 pessoas.

Até aquele momento (1996), haviam participado do PEEPIN 1350 alunos e 86 professores. A distribuição desses professores e estudantes de acordo com departamentos e cursos de origem está apresentada nas próximas duas tabelas. 
Tabela 3. Distribuição dos docentes que participaram do PEEPIN segundo departamentos do CCS e outros Centros participantes da graduação em saúde na UEL no período de 1992 a 1996.

\begin{tabular}{|l|l|l|l|l|l|l|}
\hline Lotação & \multicolumn{1}{l}{$\mathbf{1 9 9 2}$} & $\mathbf{1 9 9 3}$ & $\mathbf{1 9 9 4}$ & $\mathbf{1 9 9 5}$ & \multicolumn{1}{|c|}{1996} \\
\hline Enfermagem & 4 & 5 & 5 & 5 & 6 \\
\hline Fisioterapia & - & 3 & 4 & 6 & 6 \\
\hline Medicina* & 6 & 7 & 7 & 9 & 7 \\
\hline Odontologia** & 1 & 2 & 2 & 1 & 1 \\
\hline Patologia Aplicada & 3 & 4 & 5 & 3 & 6 \\
\hline Centro de Ciências Biológicas & 2 & 3 & 6 & 8 & 4 \\
\hline Centro de Ciências Humanas & - & 1 & 1 & 3 & 3 \\
\hline Centro de Ciências Exatas & - & 1 & 3 & 3 & 3 \\
\hline Centro de Educação, Comunicação e Artes & - & 1 & 1 & 2 & 2 \\
\hline Total & 16 & 27 & 34 & 40 & 38 \\
\hline
\end{tabular}

Fonte: Projeto UNI Londrina: processos e resultados (SOARES et al, 1996)

* conjunto dos departamentos: Medicina Interna, Cirurgia, Materno-Infantil e Saúde Comunitária

** conjunto dos departamentos: Odontologia Restauradora, Medicina Oral e Odontologia Infantil

Tabela 4 - Porcentagem de alunos que cursaram o PEEPIN em relação ao total de alunos da série por cursos do CCS-UEL

e por anos letivos no período de 1992 a 1996.

\begin{tabular}{|l|l|l|l|l|l|l|}
\hline Cursos & $\mathbf{1 9 9 2}$ & $\mathbf{1 9 9 3}$ & $\mathbf{1 9 9 4}$ & $\mathbf{1 9 9 5}$ & $\mathbf{1 9 9 6}$ \\
\hline Enfermagem & $62 \%$ & $50 \%$ & $100 \%$ & $90 \%$ & $100 \%$ \\
\hline Farmácia & $60 \%$ & $75 \%$ & $72 \%$ & $93 \%$ & $95 \%$ \\
\hline Fisioterapia & $88 \%$ & $70 \%$ & $93 \%$ & $90 \%$ & $100 \%$ \\
\hline Medicina & $21,7 \%$ & $43 \%$ & $38 \%$ & $83 \%$ & $67 \%$ \\
\hline Odontologia & $25 \%$ & $10 \%$ & $98 \%$ & $93 \%$ & $88 \%$ \\
\hline Total & $49 \%$ & $49 \%$ & $78 \%$ & $89 \%$ & $88 \%$ \\
\hline
\end{tabular}

Fonte: Projeto UNI Londrina: processos e resultados (SOARES et al, 1996)

De 1997 a 1999, participaram outros 34 professores e mais 354 estudantes no PEEPIN. Os trabalhos desenvolvidos durante essas atividades têm sido regularmente publicados em números especiais da revista Semina, mantida pela Pro-Reitoria de Pós-Graduação (SEMINA, 1996) ; (SEMINA, 1997); (SEMINA, 1998).

Nos dois primeiros anos de desenvolvimento do PAPP, foram apoiados 36 projetos envolvendo 400 participantes (180 profissionais docentes ou de serviços e 220 alunos). No primeiro ano de implantação do PAPIENS, foram apoiados 8 projetos, com a participação de 71 profissionais (docentes e de serviços) e 600 alunos (SOARES et al, 1996). 
Essas foram importantes estratégias de sensibilização e experimentação prática que, articuladas com uma ampla e sistemática oferta de atividades de capacitação em temas como metodologias ativas de ensino-aprendizagem, trabalho em grupos, planejamento estratégico, epidemiologia clínica e outros, possibilitaram aos professores a segurança de trabalhar de outra maneira e propor inovações e transformações na prática pedagógica das carreiras da saúde (GARANHANI et al, 1999).

Um outro elemento considerado fundamental para a disposição favorável à mudança, identificado por todos os entrevistados, foi a oportunidade dos professores de tomar consciência de que as críticas à formação tradicional e a busca de alternativas de mudança não estavam ocorrendo somente no Brasil e nem somente nos marcos do programa UNI: eram uma tendência internacional.

Para essa tomada de consciência foram essenciais as iniciativas da direção do CCS na primeira fase do projeto de buscar conexões, trazer ativamente o debate e a possibilidade de participação em Edimburgo, trazer para o CCS a proposta da gestão de qualidade acompanhada de um importante processo de capacitação estratégica do corpo docente, visitar e enviar gente para estudar em centros de excelência como MacMaster (Canadá) e Maastricht (Holanda) (entrevistados L1, L2, L3 e L4).

O programa UNI, através de seu programa de apoio, também propiciou viagens de conhecimento, patrocinou cursos de educação médica a distância e também mestrados presenciais (Dundee, Maastricht) para pessoas estratégicas de todos os projetos, além de estabelecer um programa de cooperação técnica com alguns dos centros internacionais de excelência nessa área, com o objetivo de possibilitar a capacitação intensiva de docentes.

Essas haviam sido estratégias comuns a todas as carreiras da saúde em Londrina, mas que produziram resultados e impactos distintos, que se potencializaram ao longo do tempo - daí a importância de desencadear processos multiprofissionais de mudança. 
Existia, já nessa época, um significativo avanço coletivo nas formulações teórico-conceituais em torno do processo de formação dos profissionais de saúde, como, por exemplo, na compreensão que tinham a respeito de currículo:

"É mais que um documento; não é constituído somente de conhecimentos válidos, mas sim de conhecimentos considerados socialmente válidos e a educação institucionalizada representa uma espécie de condensação social em cima da qual os diferentes grupos sociais refletem e projetam suas visões e expectativas" (SILVA, 1996).

E de sua interpretação a respeito do significado do PEEPIN: "uma relação dialética entre a universidade e a sociedade para qual a universidade deve produzir conhecimento" (ITO et al, 1997b) e uma concretização da compreensão de currículo como crítica:

"ênfase na necessidade de que os outros, não ligados às escolas, também se envolvam nas ações de professores e alunos, para que elas se tornem uma possibilidade real de luta pela emancipação do homem. As ações de professores e alunos não devem se restringir aos cenários educacionais em que normalmente acontecem e sim articular-se a estratégias mais amplas. Devem ser criados conteúdos novos que correspondem a uma representação cultural prévia de um futuro melhor" (YOUNG apud MOREIRA apud ITO, 1997b).

Estavam mais claras as bases conceituais da estratégia de construção da mudança: esperavam romper os muros que cercam a universidade e estabelecer uma relação dialética entre os conhecimentos disciplinares e os cotidianos, "possibilitando que os sujeitos elaborem significados próprios - e não que simplesmente os assimilem ou tomem - traçando o caminho específico de sua progressiva evolução" (ITO et al , 1997b). Consideravam que isso se daria num processo de superação do currículo como fato, como prática e como crítica e que nesse novo modelo não caberiam mais disciplinas e estruturas compartimentalizadas. Esperavam que ao mudar a lógica da produção do conhecimento conseguiriam integrar ensino, 
pesquisa e extensão dentro do currículo formal (ITO et al, 1997b) e era esse o caminho perseguido com suas estratégias de sensibilização.

Além do avanço nas formulações conceituais, havia progressos práticos. Por exemplo, na enfermagem foi possível, já em 1996, dar um passo adiante e introduzir uma reforma curricular importante, considerada pelas docentes como uma etapa intermediária antes de chegar ao almejado currículo integrado.

Além de propiciar muitos momentos de articulação interdisciplinar, esse currículo intermediário possibilitou a criação do internato de enfermagem. Como já mencionado, o internato possibilitou um aprofundamento radical do relacionamento da academia com os serviços, foi fundamental para a adequação dos espaços dos serviços para as práticas dos estudantes, para a introdução de conteúdos relevantes no treinamento prático dos estudantes, para a participação ativa dos profissionais dos serviços no planejamento de atividades, supervisão e avaliação dos estudantes em campo etc (SOARES et al, 1996), (ITO et al, 1997b).

A decisão da enfermagem de mudar, ainda que estabelecendo passos intermediários, foi muito importante para fazer acelerar o processo na medicina, onde - sob a influência da CINAEM e do projeto de Gestão da Qualidade - a avaliação estava sendo utilizada como ferramenta estratégica para mobilizar a reflexão crítica sobre as práticas tradicionais.

Os sucessivos processos de avaliação de disciplinas, de metodologias e, por fim, do curso como um todo, culminaram, em 1996, com um Seminário de Avaliação do Curso de Medicina no Sistema Seriado, que reuniu um expressivo contingente de alunos e professores.

O seminário teve um grande impacto sobre os participantes. Nas palavras de uma professora da Clínica Médica:

"Duas coisas no seminário me impressionaram sobremaneira. Uma foi a quantidade e a qualidade da participação discente, que soube discorrer com maturidade, conhecimento e até com inusitada coragem sobre o tipo de escola que deseja. A segunda, principalmente, foi a profunda reavaliação dos meus paradigmas sobre ensino médico. 
Sempre trouxe comigo que a melhor educação é a que apresenta o conhecimento de forma progressiva, dando ao aluno tempo para a sedimentação e amadurecimento. É necessário que ele aprenda primeiro o normal (básico), depois o patológico (clínico) e depois vá praticar (internato). As disciplinas do básico säo praticamente imisciveis com as do clínico. É responsabilidade do professor fazer com que o aluno aprenda....Do bom aluno espera-se apenas que consiga aprender aquilo que o professor definiu como importante, da maneira e no momento que nós consideramos ideal e que repita esses conhecimentos na prova

\section{(...)}

Ouvindo as palestras, discutindo, participando deste seminário, revi esses meus conceitos.

O objetivo inicial de qualquer estudante de medicina é instituir ou manter a saúde das pessoas e não aprender medicina. Seu grande estímulo para estudar é o contato com o paciente, com os problemas de saúde. O conhecimento do periodo básico poderia ser melhor fixado se estivesse correlacionado aos problemas de saúde, se o aluno fosse estimulado a desenvolver suas habilidades médicas (diagnosticar e tratar) logo no início do curso.( ...) O saber médico não se estabeleceu do normal para o patológico e sim do doente para o são. Por que o ensino da medicina deve ser então gradual e progressivo? (...) Nossos alunos só tomam contato real com o paciente no internato. Quando acadêmicos se preocupam em decorar o que o professor considerou importante e, quando entram no internato, vivem reclamando que não sabem fazer diagnóstico e têm dificuldade em raciocínio clínico-epidemiológico e relacionamento com o paciente.

...

E se mesclássemos esse processo? Deixemos os alunos aprender com a prática, com o contato precoce com os pacientes e os problemas de saúde da população e nós, professores, voltemos à sala de aula para que possamos refinar nosso conhecimento prático sobre o que é ser professor com fundamentos pedagógicos, metodologias de ensino e avaliação, que também são ciências e estão sendo colocadas à nossa disposição (...)" (MURAGACHI, 1996) 
Saíram mobilizados para buscar "a escola dos sonhos", que "é um espaço privilegiado para a construção da cidadania e para garantir o processo de aprender em uma construção interativa". Convencidos de que

"o que está na base de qualquer aprendizagem é o desejo de aprender e que a prática social de cada realidade precisa ser o ponto de partida e o de chegada do projeto da escola" e de que "a escola necessária para os novos tempos ainda não existe: precisa ser construida" (UNIVERSIDADE,, 1997a).

Desse seminário saiu a decisão de mudar, buscando formar um profissional de saúde

$$
\begin{aligned}
& \text { "capaz de, entre outras coisas, de avaliar e melhorar a qualidade da } \\
& \text { assistência médica prestada; usar novas tecnologias em beneficio do } \\
& \text { paciente; promover a qualidade de vida; desenvolver trabalho em } \\
& \text { equipes multiprofissionais; compreender a realidade social e } \\
& \text { comprometer-se com a solução de seus problemas" } \\
& \text { (UNIVERSIDADE, 1997a). }
\end{aligned}
$$

Nos meses seguintes, o Colegiado traçou um plano estratégico de ação para tornar possível a mudança desejada. Entre outras diretrizes, indicou-se como muito importante: manter os processos de avaliação das disciplinas; manter a aproximação com todos os departamentos envolvidos no curso de medicina bem como com suas 75 disciplinas; subordinar a preceptoria do internato às decisões do colegiado; reforçar a congregação de alunos como um importante instrumento de monitoramento do curso e de capacitação em avaliação de disciplinas, educação médica e reforma curricular.

Foi aprovado como "ideário" básico para orientar a construção da nova proposta curricular:"garantir o envolvimento docente no processo de análise e reformulação curricular; garantir o envolvimento discente no processo de análise e reformulação curricular; produzir melhorias qualitativas no processo avaliativo; garantir integração entre os vários niveis de 
atendimento à saúde; garantir a integração dos conteúdos das várias disciplinas" (UNIVERSIDADE,1997a)

As ações necessárias para atingir essas metas seriam:

"votar o referendum sobre a adoção ou não do PBL como metodologia a ser utilizada na reforma curricular do curso de medicina da UEL na reunião ordinária do Colegiado de medicina de 4 de março;constituir uma Comissão responsável pela Elaboração da Proposta de Reforma Curricular"; treinamento dos docentes em PBL; treinamento de tutores em PBL; aprovação nas instâncias necessárias para implantar o novo currículo no início de 1998" (UNIVERSIDADE, 1997a).

A partir da aprovação pelo colegiado da adoção da aprendizagem baseada em problemas como opção metodológica, a Comissão de Elaboração passou a trabalhar na construção da proposta alternativa. Foram constituídas 5 subcomissões: currículo (parte legal e operacional), desenvolvimento de problemas, habilidades e estágios, avaliação e treinamento.

Paralelamente a esse trabalho de elaboração, foram sendo construídas as alianças políticas necessárias para a aprovação da mudança pelos órgãos colegiados.

Como planejado, em agosto, a nova proposta foi aprovada no Colegiado e na seqüência pelo CEPE (Comissão de Ensino e Pesquisa, instância superior da universidade). Instalou-se, então, nova polêmica acerca da implantação imediata ou não da nova proposta - pela necessidade de acumular mais força e melhorar a preparação docente (UNIVERSIDADE, 1997a).

Venceu a posição de implantação imediata e no primeiro semestre de 1998 começou a ser implantado o novo currículo de medicina: integrado, organizado através de módulos temáticos de acordo com os ciclos de vida e baseado em problemas, com duas unidades transversais: as habilidades e as práticas interdisciplinares em saúde (UNIVERSIDADE, 1997a). 
Aí foi a vez do curso de medicina estimular o curso de enfermagem, que estava um tanto imobilizado pelos problemas e insuficiências de seu currículo de transição. A partir do lançamento da nova proposta da medicina, desencadeou-se uma nova onda de mobilização no curso de enfermagem, que culminou com a construção e aprovação de seu novo currículo, desta vez um currículo integrado, construído através de módulos interdisciplinares e baseado na metodologia da problematização, implantado no ano 2000 (GARANHANI et al, 1999).

Nos outros três cursos, a situação revelou-se mais complexa. O curso de fisioterapia contava com docentes capacitados e mobilizados, tinha uma nova proposta curricular e metodológica, mas não se animou até o momento em dar os passos necessários para implementar a mudança.

O curso de farmácia, como de resto quase todos no país, encontrava-se e continua imobilizado pelas divisões internas do corpo docente quanto à polêmica nacional relativa à formação em farmácia.

O curso de odontologia foi o que menos avançou em termos de debate, reflexão e participação dos docentes nas atividades inovadoras, contrastando com uma forte participação estudantil. Como conseqüência, não houve até o momento massa crítica com poder suficiente para colocar um processo de mudança em marcha.

\subsubsection{A necessidade de novas estratégias}

A partir de um determinado momento (1998 aproximadamente), diante do desenrolar dos fatos nas várias carreiras, foi possível perceber que, as estratégias iniciais de mobilização e sensibilização (PEEPIN, PAPP, PAPIENS, Áreas Verdes) já demonstravam sinais de esgotamento. Quer dizer, quem tinha que participar e ser sensibilizado, quem podia ser atingido por elas, já o havia sido. Havia que desenvolver novas estratégias (PROUNI, 1999). 
Empiricamente já se sabia que o maior impacto do PEEPIN, PAPP e PAPIENS havia sido sobre os professores do básico e também sobre os professores dos cursos de enfermagem e fisioterapia. Os frutos desse processo puderam ser claramente percebidos, por exemplo, através da maciça participação e suporte dos professores do básico nos processos de mudança da medicina e da enfermagem e através da coesa participação dos docentes de enfermagem no processo de transformação desse curso.

Entre os professores dos departamentos clínicos do curso de medicina, entretanto, havia existido pouca participação. Uma pesquisa realizada em setembro de 1999 através de questionário enviado por correspondência aos docentes do CCS que participam do curso de medicina (houve 80 respondentes em um universo de 196 docentes, ou seja, 41\%), confirmou que somente 19 dos respondentes haviam participado do PEEPIN e desses, 10 eram docentes do departamento de materno-infantil e saúde comunitária (TURINI, 2000). Não há dados em relação à participação dos docentes da medicina nas outras estratégias de mobilização.

Apesar dessas evidências de insuficiência, não houve a elaboração ou lançamento de outras estratégias de sensibilização, que fossem capazes de mobilizar os professores da área clínica na medicina ou os professores da odontologia e que provavelmente teriam que estar orientadas a temas relacionados com a problematização da prática clínica, que é a base de sua identificação profissional.

Essa inferência apóia-se na constatação de que na Clínica Médica 74 \% e na Clínica Cirúrgica $67 \%$ dos docentes são contratados por até 24 horas, principalmente para atividades no hospital (em enfermaria, ambulatório e prontosocorro) - o que indica que o centro de sua atividade é a prática clínica e explicaria porque não se interessaram pela reflexão sobre a prática docente. Além do mais, $24 \%$ dos docentes da Cirurgia e $55 \%$ da Clínica são apenas graduados ou especialistas, o que pode ser tomado como indicativo de menor dedicação a 
atividades de pesquisa - e explicaria porque não foram atraídos por estratégias de incentivo à pesquisa e à produção de conhecimento.

Essa dificuldade de elaborar novas estratégias e a resistência em manter-se em movimento permanente de mudança (por exemplo, reconhecendo as limitações atuais e superando as estratégias revolucionárias dos projetos especiais) são parte do já mencionado quadro de relativa estagnação que começou a estabelecer-se na direção do projeto UNI e do CCS.

\subsubsection{Os espaços de poder}

Como mencionado, ao início do projeto UNI estava em curso no CCS uma gestão peculiar: diretor da saúde comunitária, vice-diretora da enfermagem, ambos com tempo completo. A grande marca desta gestão, reconhecida por todos os entrevistados, foi sua enorme capacidade de mobilização, de criação de oportunidades para reflexão e de estabelecer conexões importantes para colocar o Centro em movimento.

Também se mencionou que esse processo não aconteceu pacificamente. Ao contrário, houve uma importante resistência e muitos conflitos, tanto durante o processo eleitoral, como depois na adesão ao UNI.

Além do processo democrático e participativo, que possibilitou a criação de uma massa crítica e ativa de docentes, houve dois outros movimentos muito importantes desencadeados pela direção do CCS.

Por um lado, a ocupação dos espaços eletivos estratégicos (chefias de departamento, representação e coordenação nos e dos colegiados) por pessoas comprometidas e mobilizadas com a proposta de mudança. Desse modo, foi sendo conquistado o espaço para as decisões que favoreciam a introdução de inovações e, mais tarde, a aprovação das propostas de reforma curricular.

Por outro lado, havia a firme convicção de que nenhuma mudança profunda seria possível sem a participação ativa e efetiva dos clínicos. Foi, então, 
sendo construída a aliança, que culminou na eleição do professor da clínica médica para a direção do CCS por dois períodos consecutivos (94 a 2002). No primeiro período, a vice-diretoria foi ocupada por uma representante da saúde comunitária e no segundo por uma representante da enfermagem, ambas ativas militantes dos processos de inovação.

Apesar das diferenças entre diretor e vices, passou a predominar à frente do CCS, especialmente a partir de 1998 um estilo muito diferente de condução, quando comparado às fases anteriores (como já mencionado em relação à direção do projeto $\mathrm{UNI})$.

Menos iniciativa, menos estratégia, menos debate aberto, menos reflexão coletiva, menos planejamento, menos avaliação sistemática, menos enfrentamento explícito de conflitos. Mais costura miúda no dia-a-dia, mais sedução, mais contemporização, mais "laissez-faire", mas também mais diálogo com os clínicos, conquista de algumas adesões estratégicas, muitas realizações e ânimo, apesar da maior improvisação.

A massa crítica que havia sido forjada nos anos anteriores estava e continuou em ação, entretanto, em vários espaços do CCS e do trabalho em parceria com serviços e comunidade.

No caso da medicina e da enfermagem, os colegiados passaram a ser espaços fundamentais para a dinamização dos processos. A coordenação do componente acadêmico do projeto UNI, bem como a do internato de enfermagem cumpriam papel fundamental na alimentação permanente da relação de parceria com os profissionais dos serviços de saúde e com a comunidade.

A CPDC (Comissão Permanente de Desenvolvimento Curricular), que reúne os coordenadores de colegiado dos cursos do CCS conseguiu manter-se como um espaço de debate de estratégias e de produção de conhecimento relevante para as transformações educacionais, inclusive mantendo a publicação da revista Olho Mágico. 
O colegiado de medicina, como os demais, foi criado em 1992 e em 1994 passou a ser coordenado por um ardoroso adepto das propostas de mudança, que deu início ao processo de avaliação sistemática do curso de medicina, além de viabilizar a autonomia financeira do colegiado.

De 96 a 99, o colegiado de medicina foi dirigido pela Chapa Jeolás², composta por uma dupla de militantes da mudança: um professor da saúde coletiva e um professor da anatomia patológica (UNIVERSIDADE, 1997a). Essa direção cumpriu papel fundamental na mobilização permanente dos docentes e estudantes, na criação de espaços de reflexão e na construção das alianças necessárias à viabilização da mudança.

Os estudantes foram atores decisivos no processo de avaliação crítica das práticas tradicionais e na exigência por mudanças imediatas no processo de formação.

Participantes ativos das atividades desencadeadas através dos projetos especiais, reativaram o Centro Acadêmico, criaram uma Central de Investigação, estabeleceram relações e processos de cooperação diretamente com as comunidades, reivindicaram capacitações etc.

De maneira indireta, os estudantes contribuíram para um outro elemento considerado importante na disposição de mudança dentro do curso de medicina: os filhos de muitos dos docentes "veteranos e pioneiros" estudavam medicina no CCS nos anos 90. O olhar crítico dos filhos ao processo de formação tornou ainda mais explícita a disposição dos pais (e mestres) em relação à mudança (entrevistados L1 e L2).

Os estudantes desencadearam até um episódio de conflito explícito com os professores ao publicarem em seu jornal, "Caolho" em agosto de 1996, como contribuição ao "Seminário de Avaliação do Sistema Seriado do Curso de Medicina", uma avaliação, disciplina por disciplina, dos professores do curso,

\footnotetext{
${ }^{2}$ Luis Carlos Coelho Neto Jeolás foi professor titular do CCS/UEL, artista plástico e um educador comprometido com a realidade social, valorizando a relação da universidade com os serviços de saúde.
} 
mencionado todo tipo de problema e de qualidade: metodologias, pertinência, atrasos, faltas, transparências amareladas etc (CAOLHO, 1996). Houve reações violentas a essa publicação e o debate a respeito foi parar até no jornal da Associação Médica.

Doloroso, mas fundamental, o episódio sem dúvida contribuiu para a decisão, no Seminário de Avaliação, por uma mudança radical do projeto pedagógico e do currículo do curso de medicina da UEL.

Um ano depois, outra vez no "Caolho", os estudantes comemoravam a aprovação pelo colegiado de medicina da nova proposta curricular:

"Sempre há um limite. O atual currículo vigente já não suporta mais remendos. A tarefa de querer mudar nunca foi fácil, mas em nenhuma outra época houve tantas discussões, debates e confrontos entre todos os segmentos componentes do curso de medicina em relação à construção de um modelo pedagógico que possa atender ás necessidades de interdisciplinaridade, maior interação comunitária, mudança da atitude passiva do estudante para a ativa busca do conhecimento e a humanização do profissional médico a ser formado pela UEL".

"Fruto do trabalho de vários pensadores e "sonhadores", que fazem parte do curso de medicina, e do grande incentivo do PROUNI em trazer novas idéias para Londrina, construiram-se as bases das mudanças que a comissão de laboração do anteprojeto do novo currículo de medicina propôs após 150 dias e "noites" de trabalho.

No dia 12 de agosto de 1997, o colegiado aprovou a implementação da metodologia do PBL no novo currículo da medicina a ser aplicado a partir de 1998 para as novas turmas que ingressarem na UEL.

As atitudes tomadas a partir desta data só atingirão seus objetivos se houver a colaboração e a participação de todos os membros que constituem o curso de medicina. A tarefa será árdua, mas o barco só está começando a navegar" (ISHII et al, 1997). 
Em 2000 e 2001, manteve-se a composição da direção do colegiado de medicina, mas com cargos invertidos - o coordenador passou a vice e o vice a coordenador. Essa mudança também implicou em transformações no estilo de direção. Examinaremos mais adiante, com maior cuidado, o funcionamento do colegiado e de outras instâncias do curso de medicina a partir de 1998, ano em que começou a implantação do novo currículo de medicina.

Em 1998, o ex-diretor do CCS que havia estado à frente do projeto UNI em seu início, assumiu a vice-reitoria da UEL, numa aliança polêmica com o reitor do período imediatamente anterior.

Essa aliança, por um lado, possibilitou que a dinamicidade conferida ao CCS à épóca de sua gestão fosse transportada para determinados âmbitos da gestão universitária, especialmente para a CAE (Pro-reitoria de Graduação) e para a CPG (Pro-reitoria de Pós-graduação). Algumas pessoas-chave do setor de saúde comunitária do CCS passaram a desempenhar um papel importante nas esferas mais altas da universidade (algumas com cargos e outras sem cargo).

Novas regras que conferiam maior flexibilidade aos currículos, aos estágios realizados fora dos muros da universidade, novo sistema de vestibular (agora assumido pela UEL em parceria com a UFPR e antes comprado à Fundação Carlos Chagas), foram algumas das decisões importantes tomadas neste período. Estímulo ao debate educacional, ao desenvolvimento da pesquisa em todas as unidades acadêmicas, ao planejamento estratégico, às atividades de avaliação, ao compromisso social etc. foram outros elementos da política desenvolvida.

Por outro lado, essa participação fez estremecer algumas das alianças internas ao CCS, que eram - e continuam sendo - importantes para a transformação em curso. Também, deve-se ressaltar, que a participação nas esferas superiores da universidade afastou, na prática, alguns elementos importantes do trabalho mais cotidiano nos novos currículos no CCS (entrevistado L 2).

Essa gestão da reitoria terminou de maneira abrupta em junho de 2001, com a renúncia do vice-reitor ao cargo, denunciando irregularidades e suspeita de 
corrupção por parte de membros da equipe de colaboradores íntimos do reitor. As investigações desencadeadas a partir das denúncias do ex-vice-reitor levaram ao "impeachment" do reitor, à sua demissão da universidade e a um processo de transição política que só foi concluído um ano depois, em junho de 2002.

O então diretor do CCS, por ser o decano mais antigo, foi indicado pelo Conselho Universitário para ocupar interinamente o cargo de reitor até a realização de novas eleições. Logo em seguida (setembro de 2001), foi desencadeada uma greve de professores e funcionários por melhores salários que teve seis meses de duração.

Um momento tenso e confuso, que antecede os decisivos processos sucessórios nos departamentos e colegiados, depois na direção do centro e na própria reitoria, exatamente no período de consolidação dos processos de mudança na medicina e na enfermagem.

\subsubsection{O trabalho em outros âmbitos}

Desde o início da participação do UNI e no período imediatamente anterior, como já mencionado, foi feito um significativo esforço de inserir o CCS no movimento nacional e internacional de mudança na formação dos profissionais de saúde.

Sede do XXX Congresso da ABEM em 1992, Londrina vem mantendo um representante na diretoria da Associação Brasileira de Educação Médica há já vários anos.

Primeira escola a responder ao questionário de avaliação da primeira fase da CINAEM, foi sede de seminários da segunda fase - que ajudou a financiar juntamente com os outros projetos UNI brasileiros - e continuou sendo participante ativo desse processo, embora com muitas restrições à sua condução nos últimos anos. 
Logo no início dos anos 90, o CCS aderiu à Rede IDA e foi ator fundamental na reviravolta da Rede, que levou a que ela se convertesse na Rede UNIDA e que passasse a cumprir o papel de um ator político importante no cenário da educação dos profissionais de saúde no Brasil (COSTA et al, 2000).

Representantes do CCS tiveram participação decisiva no movimento de debate em torno das novas diretrizes curriculares para as profissões da saúde que foi liderado pela Rede UNIDA a partir de 1998.

Atualmente a secretaria executiva da Rede UNIDA está no CCS e foi em Londrina o IV Congresso da Rede UNIDA, realizado em outubro de 2001. Articulações no sentido de ampliar as ações da Rede em favor do movimento de mudanças têm sido trabalhadas em cooperação com a ABEM, o CONASEMS, o CNS, o Ministério da Saúde, o Fórum de Pro-reitores de Extensão etc.

Também em 1993 o CCS tornou-se membro da Network of Community Oriented Institutions for Health Sciences ${ }^{3}$, sendo que um de seus representantes atualmente coordena o Capítulo Latino-americano dessa instituição e, em 2001, Londrina foi a sede do Congresso Internacional bienal desse movimento.

A partir da implantação dos novos currículos na medicina e na enfermagem, representantes do CCS têm sido chamados a cooperar com outras escolas interessadas em começar processos inovadores.

O CCS, particularmente através do ex-Setor de Saúde Comunitária, agora Departamento de Saúde Coletiva, tem ativa participação no Pólo de Saúde da Família, desenvolvendo uma inovadora metodologia de capacitação profissional, baseada na Educação Permanente.

\footnotetext{
${ }^{3}$ Atualmente a Network se chama Network of Community Partnerships for Health through Innovative Education, Service and Research.
} 


\subsection{O novo curso de medicina da UEL}

A nova proposta para o curso de medicina foi discutida e elaborada por professores e estudantes dos quatro centros que participam da formação médica, tendo como base os princípios centrais de "um novo modelo acadêmico", que busca excelência técnica e relevância social, construído no CCS ao longo da década de 90 , que são:

"articulação academia - serviços- comunidade; interdisciplinaridade; ação multiprofissional; ensino e pesquisa orientados por problemas prioritários de saúde da população; formação orientada para a atenção integral à saúde; articulação ensino-pesquisa-assistência; integração do conhecimento das disciplinas básicas e clínicas; inserção precoce do aluno em açōes comunitárias e nos serviços de saúde; ensino baseado em problemas como uma das metodologias inovadoras de ensino-aprendizagem; prática tutorial na relação professor-aluno predominando em relação às aulas expositivas; uso de tecnologia apropriada; educação permanente como compromisso da universidade" (CAMPOS \& GORDAN, 1997).

A nova proposta buscava superar os problemas que haviam sido diagnosticados nos sucessivos processos de avaliação realizados nos anos anteriores (UNIVERSIDADE, 1997b) e que eram os seguintes:

- excessiva segmentação/individualização e falta de especificidade das disciplinas na área da saúde do ciclo básico, levando a dissociação entre conhecimentos básicos e clínicos

- enfoque essencialmente biologista

- informações de especialidades de ponte introduzidas com a mesma importância e destaque que conteúdos gerais

- estrutura curricular por disciplinas, com excessiva e crescente fragmentação do ensino (àquela altura já eram 75 disciplinas) 
- má utilização das cargas horárias, havendo desperdício de tempo, com cargas horárias não cumpridas (as áreas "negras")

- metodologia de ensino baseada essencialmente na transmissão do conhecimento, que gera passividade dos alunos e desmotivação dos professores

- avaliação da aprendizagem baseada na memorização, essencialmente somativa e não formativa

- atividades fragmentadas e essencialmente teóricas nas $3^{a}$ e $4^{\text {a }}$ séries

- ausência de práticas nos cenários comunitários e nos serviços de saúde de primeiro e segundo nível

- sobrecarga de atividades em sala de aula, dificultando iniciativas de ensino-aprendizagem e de investigação científica por parte de docentes e estudantes objetivos:

A nova proposta de organização do curso médico apresentava como "geral: garantir e aperfeiçoar a formação geral do médico graduado pela UEL em termos técnicos, científicos e humanísticos" especificos: adequar constantemente o currículo médico, visando a formação de profissional apto a resolver a grande maioria dos problemas de saúde da população; aprimorar a relação médico-paciente, aumentando a responsabilidade acadêmica;integrar o curso básico com o clínico;melhorar os sistemas de avaliação do processo de ensino-aprendizagem e do curso;valorizar a visão bioética da medicina;estimular a compreensão do paciente como ser biopsicossocial; contribuir para o desenvolvimento de práticas multiprofissionais em ensino, pesquisa e assistência, atuando de maneira articulada com os demais cursos do CCS; participar das iniciativas desenvolvidas pelo CCS no campo da educação médica em âmbito nacional e internacional" (UNIVERSIDADE, 1997b).

Além disso, pretendia formar um médico com os seguintes atributos: 
- estimulado e capacitado para a prática da educação permanente com predomínio da auto-aprendizagem, com domínio das técnicas de leitura e análise crítica das informações;

- com domínio dos conhecimentos que dão base científica de natureza biopsicossocial à prática médica;

- com domínio dos conhecimentos necessários à prevenção, tratamento e reabilitação das doenças de maior prevalência e dos aspectos da saúde ao longo do ciclo biológico: saúde individual da criança, adolescente, adulto e geronte com as peculiaridades de cada sexo; saúde da família e da comunidade; problemas ocupacionais, ambientais e iatrogênicos;

- capaz de exercer medicina utilizando procedimentos diagnósticos e terapêuticos validados cientificamente e apropriados para a atenção integral à saúde nos níveis primário, secundário e terciário, conhecendo critérios de indicação e contra-indicação, limitações, riscos e confiabilidade

- capaz de informar e educar seus pacientes e família em relação à promoção da saúde, prevenção, tratamento e reabilitação através de técnicas adequadas de comunicação

- capaz de exercer a medicina com postura ética e visão humanística do paciente, sua familia e comunidade, observando os aspectos sociais, culturais, psicológicos e econômicos relevantes do contexto

- que saiba atuar em equipe multiprofissional, de acordo com os limites de seu saber e responsabilidade e com princípios éticos e bioéticos

- que tenha uma visão social do papel do médico e aceitar engajar-se em atividades de política e de planejamento em saúde

- capaz de utilizar ou administrar recursos financeiros e materiais observando a efetividade e conhecimentos validados cientificamente. 
A Figura 8 mostra a imagem gráfica utilizada para definir as características principais da nova proposta:

Figura 8 - Esquema geral do currículo de medicina da UEL a partir de 1998.

\section{Esquema geral do currículo}

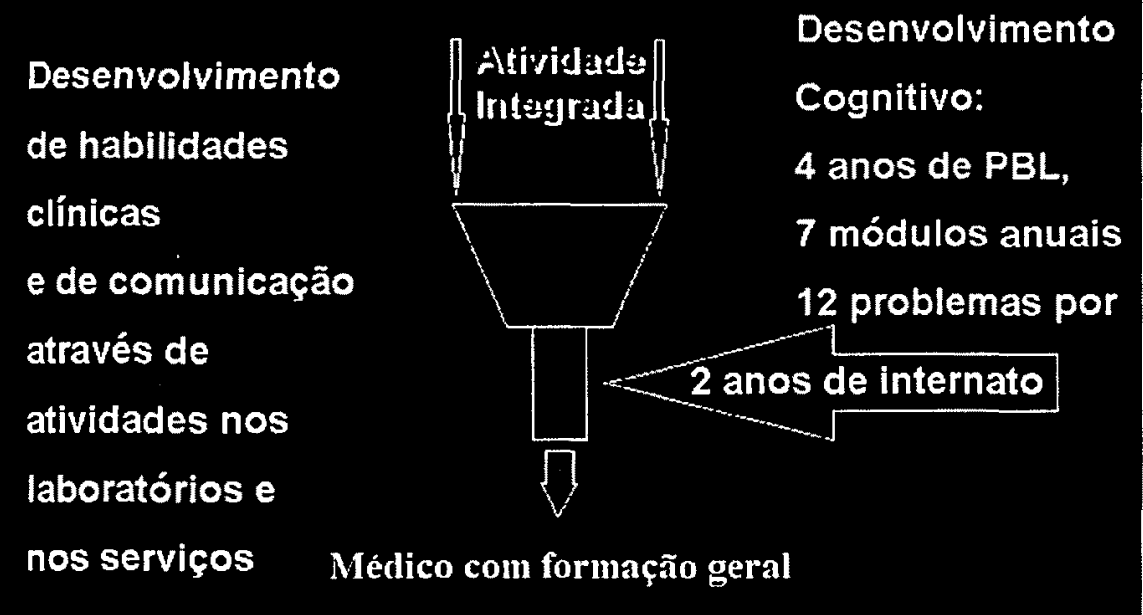

Fonte: Apresentação no seminário do componente acadêmico dos projetos UNI (CAMPOS \& BADUY, 2000).

A Figura 9 mostra um exemplo de semana padrão da nova estrutura proposta para o curso de medicina da UEL:

Figura 9. Semana Padrão do $1^{\circ}$ ano do curso de medicina da UEL em 1998.

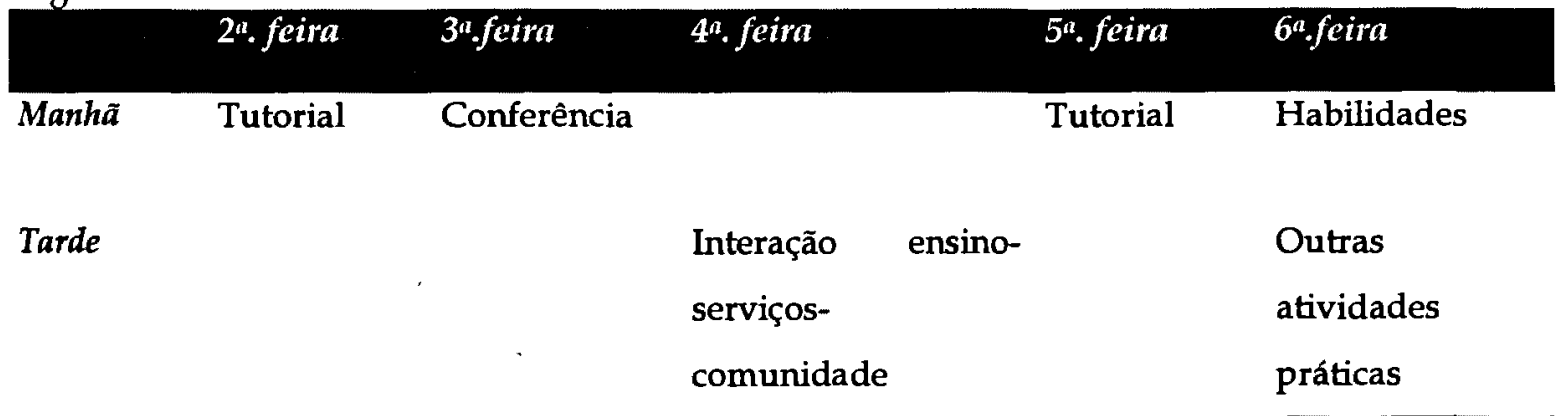

Fonte: Novo currículo de medicina da UEL (UNIVERSIDADE, 1997b). 


\subsubsection{O projeto político-pedagógico}

São seis as diretrizes do novo curso: ensino baseado na pedagogia da interação; ensino centrado nas necessidades de aprendizagem do estudante; estruturação modular do currículo, com os conteúdos das ciências básicas e clínicas desenvolvidos de forma integrada com os problemas prioritários de saúde da população; contato do estudante de medicina com as realidades de saúde e socioeconômicas da comunidade desde o primeiro ano do curso; currículo nuclear comum a todos os estudantes ao lado de práticas e módulos eletivos para possibilitar a individualização do currículo; avaliação formativa e terminalidade do curso em 6 anos (CAMPOS, 1999).

O modelo político-pedagógico proposto está fundamentado nos princípios da pedagogia interativa, de natureza democrática e pluralista, da aprendizagem, que coloca o estudante como sujeito da aprendizagem e o professor como facilitador desse processo, elegendo a metodologia da aprendizagem baseada em problemas como proposta pedagógica central (UNIVERSIDADE, 1997b).

O primeiro conceito a destacar, seria o da adoção da pedagogia da interação em lugar da pedagogia da transmissão: quer dizer, nessa proposta o estudante tem um papel ativo na busca e construção dos conhecimentos, estimulado pelos desafios colocados por um problema. Essa alternativa possibilitaria "o desenvolvimento pelos estudantes de seu próprio método de estudo e de seleção e análise crítica dos recursos educacionais mais adequados" (UNIVERSIDADE, 1997b).

O segundo conceito a se destacar seria o de aprender fazendo, que está baseado na assunção de que o conhecimento se produz da prática para a teoria. Destacou-se a importância de priorizar a prática profissional como ponto de partida para a produção do conhecimento, mas também se abriu a possibilidade de que esse processo fosse desencadeado a partir de idéias, reflexões e questionamentos. A possibilidade de prática seria oferecida aos estudantes ao longo de todo o curso e nos mais variados cenários: comunidade, unidades básicas 
de saúde, ambulatórios, enfermarias, laboratórios de natureza variada (UNIVERSIDADE, 1997b).

O terceiro conceito fundamental a resgatar seria o da articulação dos aspectos biológicos, psicológicos, socioeconômicos e culturais, já que "as ciências médicas se situam na interface das ciências biológicas e das ciências humanas" (UNIVERSIDADE, 1997b).

O quarto conceito deriva do primeiro, pois a metodologia de aprendizagem baseada em problemas seria uma das alternativas para concretização da pedagogia da interação. Segundo o documento do Colegiado (UNIVERSIDADE, 1997b), a metodologia da aprendizagem baseada em problemas "parece-se muito com a metodologia científica, pois a partir de um problema, busca-se compreendê-lo, fundamentálo e analisá-lo com base em dados e informações; por último são elaboradas hipóteses de solução, que devem ser colocadas em prática para serem comprovadas e validadas".

Para os módulos de interação ensino-serviço-comunidade (a serem apresentados em seguida) propunha-se a manutenção da metodologia utilizada no PEEPIN, ou seja, a problematização.

\subsubsection{A concepção de currículo}

A interdisciplinaridade é a base fundamental para a organização de um currículo integrado. O currículo é organizado através de módulos temáticos, compostos por problemas construídos a partir das árvores explicativas desenvolvidas a partir dos temas em pauta. Os eixos temáticos propostos para orientar a conformação dos módulos são o ciclo vital (concepção, nascimento, crescimento, envelhecimento, morte) e o modelo ecológico (processo saúdedoença como resultado da interação do homem com seu ambiente de vida).

A proposta é que cada módulo e seus respectivos problemas sejam construídos com a participação de um grupo de professores, representativo de todas as disciplinas que tenham contribuições essenciais para seu desenvolvimento, articulando conhecimentos básicos e clínicos. Na construção de cada módulo seria necessário enfrentar o desafio de articular a contribuição de 
cada disciplina com a visão unitária do currículo orientado pelo o perfil do médico que se quer formar. A construção dessa perspectiva unitária demandaria abordagens interdisciplinares e transdisciplinares na operacionalização do currículo (CAMPOS, 1999).

A Figura 10 ilustra o novo desenho curricular do curso de medicina:

Figura 10 : Estrutura curricular do curso de Medicina da UEL a partir de 1998.

\begin{tabular}{|c|c|c|c|c|c|c|}
\hline 451.56 & $\begin{array}{c}\text { Medalo } \\
22=0\end{array}$ & $\begin{array}{l}\text { Mesdelo } \\
\text { i }\end{array}$ & $\frac{\text { Madelo }}{6}$ & $\frac{\text { Modelo }}{\mathrm{s} \text { il }}$ & 16 & 24 \\
\hline 2 & 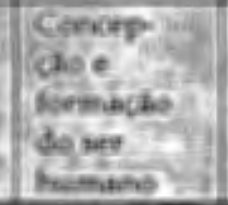 & 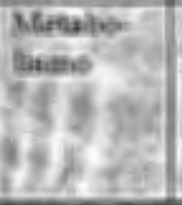 & 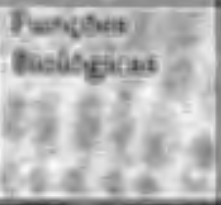 & 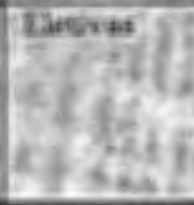 & 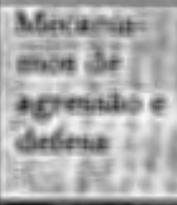 & 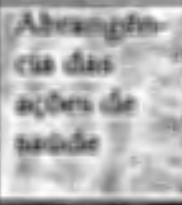 \\
\hline & 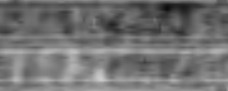 & $3+5064.4$ & 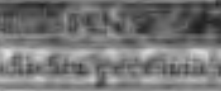 & & & \\
\hline 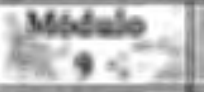 & $\frac{\text { Mód }}{10}$ & $\begin{array}{c}\text { Mesdulo } \\
11\end{array}$ & $\begin{array}{c}\text { Mestale } \\
-12\end{array}$ & $\begin{array}{r}\text { Meodu! } \\
13\end{array}$ & $\begin{array}{r}\text { Mode? } \\
14\end{array}$ & 5. \\
\hline$\theta$ & 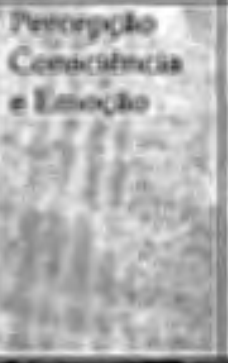 & 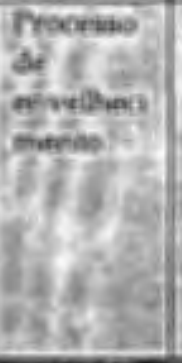 & 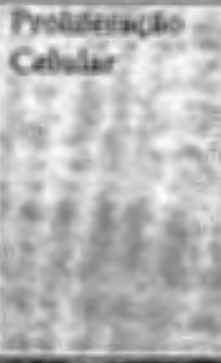 & 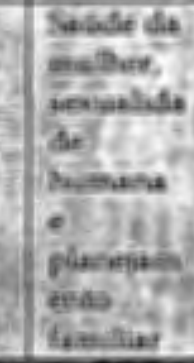 & 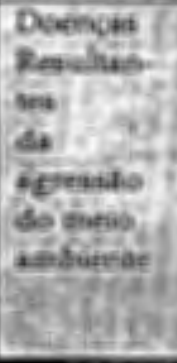 & 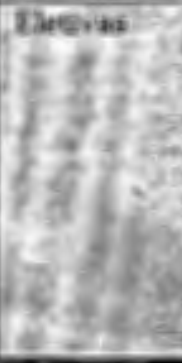 \\
\hline & 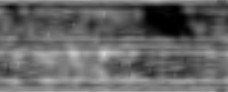 & (5) & atstimest & dus? & & \\
\hline ME: & $\begin{array}{l}\text { Masdalo } \\
\text { Etis }\end{array}$ & $\begin{array}{c}\text { Mobselo } \\
19\end{array}$ & $\frac{M a d e}{320}$ & $\frac{\text { Modele }}{21}$ & Notid & $\frac{604}{23}$ \\
\hline Deq & 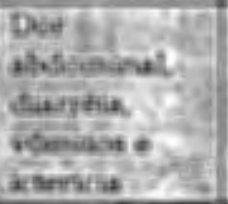 & 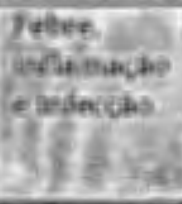 & 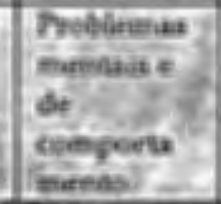 & $\begin{array}{l}\text { Neride de } \\
\text { witheut }\end{array}$ & 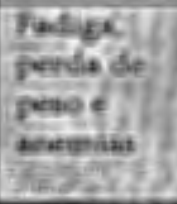 & $-5+2$ \\
\hline & 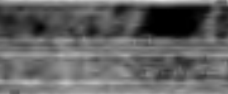 & & & & & \\
\hline$\frac{2364=10}{28}$ & $\frac{\text { Medelo }}{25}$ & $\frac{\text { Mfodelo }}{2 t}$ & 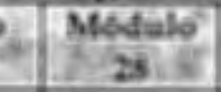 & $\frac{\text { Mesdulo" }}{28}$ & $\begin{array}{c}\text { Medele } \\
\text { Sow }\end{array}$ & $\begin{array}{c}\text { Médek } \\
131\end{array}$ \\
\hline Choomente: & 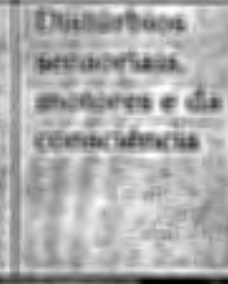 & 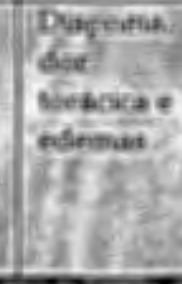 & 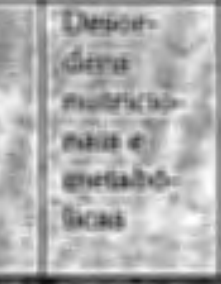 & 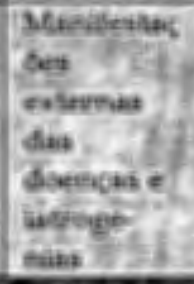 & 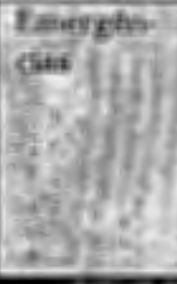 & 5 at \\
\hline res & & & & $F$ & & \\
\hline
\end{tabular}

Fonte: UNIVERSIDADE, 1997b. 
A Aprendizagem Baseada em Problemas tem o PROBLEMA como elemento motivador do estudo e integrador do conhecimento. Os estudantes discutem o problema seguindo a técnica dos "sete passos": 10 Ler atentamente o problema e esclarecer termos desconhecidos; $2^{\circ}$ Identificar as questões propostas pelo enunciado; $3^{\circ}$ Oferecer explicações para estas questões com base no conhecimento prévio que o grupo tem sobre $o$ assunto; $4^{\circ}$ Resumir estas explicações; $5^{\circ}$ Estabelecer objetivos de aprendizagem que levem o estudante ao aprofundamento e complementação destas explicações; $6^{\circ}$ Estudo individual respeitando os objetivos levantados e 70 Rediscussão no grupo tutorial dos avanços de conhecimento obtidos pelo grupo (CAMPOS, 1999).

Orientado por estas diretrizes, o aluno desenvolve seu próprio método de estudo, aprende a selecionar criticamente os recursos educacionais mais adequados e vivencia o trabalho em equipe, o que possibilita seu aperfeiçoamento contínuo em conhecimentos, habilidades e atitudes (CAMPOS, 1999).

As principais fontes de informação utilizadas pelos estudantes são livrostexto, periódicos científicos, páginas eletrônicas da internet, consultorias com professores especialistas, entrevistas com outros profissionais de saúde, arquivos e sistemas de informação especialmente dos serviços públicos de saúde e outros (TURINI, 2000).

Durante as sessões de tutoria, as atividades são desenvolvidas pelos estudantes em grupo. O tutor tem o papel de facilitar o processo, assumindo a orientação geral do trabalho, estimulando as discussões, eventualmente indicando fontes e meios para a aprendizagem. O tutor, portanto, não deve assumir a explicação direta dos fenômenos em discussão (TURINI, 2000).

Os conceitos envolvidos na construção dos módulos e o trabalho nos tutoriais estão sintetizado pelos docentes do CCS na Figura 11: 

UEL.

\section{Os móduilos temáticos}

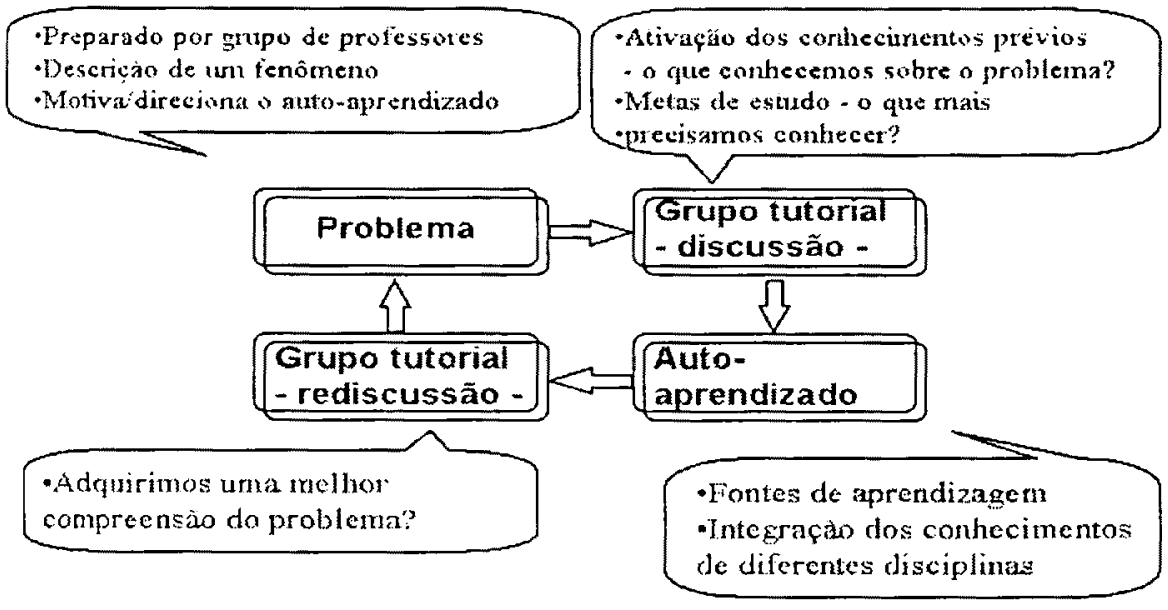

Fonte: Apresentação no seminário do componente acadêmico dos projetos UNI (CAMPOS \& BADUY, 2000).

Além do desenvolvimento dos módulos, que implicam, portanto, a existência de duas sessões semanais de tutorias e de $x$ períodos de estudo independente dos estudantes, há outras duas linhas de atividades, que são longitudinais (quer dizer, existem ao longo de todo o ano letivo) e também transcurriculares, porque estão presentes ao longo das quatro primeiras séries, ocupando um período semanal cada uma: o módulo de interação ensino-serviços-comunidades (que recebeu originalmente a sigla PIN) e o módulo de capacitação em habilidades.

O PIN corresponde aos módulos 8, 16, 24 e 32, desenvolvidos, respectivamente, ao longo do $1^{\circ}, 2^{\circ}, 3^{\circ}$ e $4^{o}$ anos do curso (PIN1/PEEPIN, PIN2,PIN3, PIN4). As atividades se concretizam através de grupos de trabalho e estudo, de preferência multiprofissionais, com conteúdos teórico-práticos relacionados com os conteúdos dos módulos, adotando a metodologia da problematização. Os campos de atuação desses grupos seriam os ambientes comunitários, as equipes de saúde da família, as unidades básicas de saúde, os hospitais gerais de segundo nível (da Zona Norte e da Zona Sul e a Maternidade Municipal) e o hospital universitário (terciário). 
O trabalho nesses vários campos seria introduzido ao longo dos 4 anos, envolvendo atividades com complexidade crescente, mas priorizando os cenários de aprendizagem extra-hospitalar, "já que o hospital seria o espaço prioritário para as atividades de internato e residência médica" (UNIVERSIDADE, 1997b). O documento destaca que há dezenas de docentes capacitados para trabalhar nos cenários de prática com a metodologia da problematização graças à experiência desenvolvida durante anos com o PEEPIN.

A Figura 12 ilustra $\circ$ tratamento pretendido para as atividades multiprofissionais ao longo dos módulos PIN:

Figura 12. Evolução das práticas com e sem especificidade profissional ao longo dos módulos de práticas interdisciplinares e multiprofissionais no curso de medicina da UEL

\section{Práticas interdisciplinares e multiprofissionais}

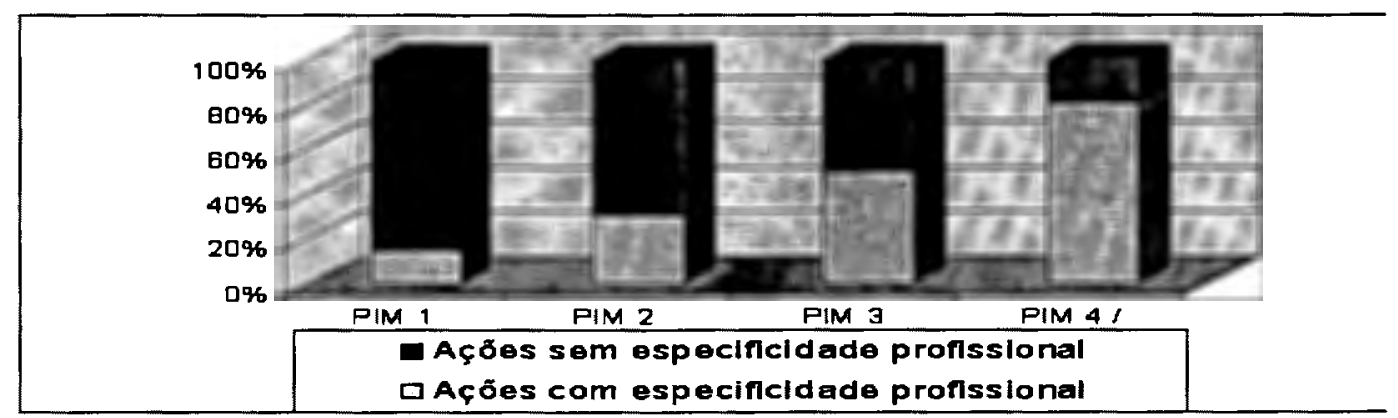

Fonte: Apresentação no seminário do componente acadêmico dos projetos UNI (CAMPOS \& BADUY,2000).

Quanto à capacitação em habilidades, diz-se que as habilidades foram definidas considerando a necessidade de "melhorar a formação médica com vistas a uma maior humanização da relação médico-paciente", de favorecer a integração do médico "na sua comunidade, bem como com outros profissionais de saúde", de capacitar o médico para realizar exames e para "manter-se bem informado sobre assuntos do seu interesse profissional" (UNIVERSIDADE, 1998a). 
Diz-se também que essa capacitação

"será realizada não só através de práticas nos momentos de interação ensinoserviços-comunidade, mas também nos laboratórios de habilidades. Estas serão programadas/agendadas com periodicidade semanal ou quinzenal para cada grupo tutorial, o que merecerá na época oportuna, um calendário específico a ser construído em conjunto pelo(a) responsável pelo laboratório e pelos (as) responsáveis pela coordenação de cada uma das séries e dos módulos de ensino. Estas atividades em laboratório deverão ocupar cerca de 2 horas semanais ou quinzenais, dependendo das características próprias de cada conjunto de habilidades a serem trabalhadas pelos alunos" (UNIVERSIDADE, 1997b).

Além dessas atividades, estava também prevista a possibilidade de uma conferência semanal, que teria como objetivo contribuir para "a sistematização de conteúdos $e$ a indicação de meios e instrumentos para auxiliar na análise dos problemas abordados" no módulo em desenvolvimento.

Os módulos eletivos, oferecidos uma vez ao ano para cada série, conferem mais um aspecto de flexibilidade à nova proposta curricular. Num período de 2 a 4 semanas os estudantes elegem, dentro de uma lista de possibilidades ofertadas pelo CCS, as atividades que desejam desenvolver. Desde estágios (supervisionados) em algum cenário de prática, até estágio em um laboratório específico, qualquer possibilidade é considerada válida.

\subsubsection{Os cenários de aprendizagem e o conteúdo das práticas}

O novo currículo valoriza de modo significativo a necessidade da prática integradora desde o início do curso e realizada nos mais variados espaços de ensino-aprendizagem. Considera-se que a oportunidade de trabalhar "desde os inícios do curso em todo tipo de cenário da 'vida real' onde se produz saúde (espaços comunitários, escolas, creches, equipes de saúde da família, unidades básicas de saúde, ambulatórios, hospitais gerais, hospitais de ensino)" é de fundamental importância. 
Destaca-se a relevância da existência de outros espaços de aprendizagem que não os universitários, pois eles "possibilitam aos estudantes integrar-se à lógica da prestação de serviços, da atenção à saúde das pessoas e das comunidades, tomando por base problemas e situações reais" (UNIVERSIDADE, 1999d).

Como mencionado, ao menos um período semanal ao longo de todo o ano, em cada série, está destinado a práticas de integração com os serviços de saúde e a comunidade. Essas práticas pressupõem a integração dos estudantes às equipes de trabalho em saúde para o desenvolvimento de ações e de pesquisas voltadas à resolução/enfrentamento de problemas prioritários de saúde (UNIVERSIDADE, 1997b).

Os cenários alternativos também poderiam ser trabalhados nos módulos de capacitação de habilidades e nos módulos eletivos, o que possibilitaria aos estudantes o desenvolvimento de múltiplas atividades e de múltiplas habilidades.

A nova proposta curricular deixou intacto o internato, considerado de boa qualidade e realizado inteiramente dentro do hospital universitário, especialmente nas enfermarias e pronto-socorros (UNIVERSIDADE, 1997b).

Na proposta originalmente apresentada não há uma discussão específica a respeito do conteúdo das práticas. No entanto, há definições inicialmente implícitas no documento original, que foram sendo explicitadas ao longo da construção dos módulos e da implementação do novo currículo.

Serão apresentadas aqui as primeiras definições, relativas basicamente aos dois primeiros anos de implementação. Como o currículo novo foi sendo construído ao longo do tempo - o $1^{\circ}$ ano logo depois da aprovação da proposta, o $2^{\circ}$ ano ao longo da implantação do $1^{\circ}$ e assim sucessivamente - muitas definições foram sendo explicitadas e aprofundadas ao longo do tempo. E também muitas modificações ocorreram - mas elas serão analisadas mais para frente, na discussão sobre o que aconteceu na prática.

O PIN é considerado: 
"um espaço fundamental de prática multiprofissional para os estudantes de saúde...num espaço cuja principal função é o cuidado à saúde nas suas mais variadas dimensões. O espaço real, com problemas reais e pessoas reais, é fundamental para a formação dos estudantes, para que eles sejam capazes de estabelecer relações humanas de melhor qualidade com a população $e$ com os outros profissionais da área. O conteúdo clínico dessa experiência deve ir crescendo aos poucos" (UNIVERSIDADE, 1999d).

O curso de medicina foi o primeiro a implantar a mudança curricular radical, mas preservou em sua proposta o espaço de ação multiprofissional com as outras carreiras, que havia sido criado com o PEEPIN. Assim, o PIN 1 confunde-se inicialmente com o PEEPIN, com a distinção de que esta é uma atividade obrigatória para os estudantes de medicina e ainda seguia sendo eletiva para os demais cursos..$^{4}$

Durante o PIN1/PEEPIN,

"os alunos desenvolveram trabalho em grupos multiprofissionais nas áreas de abrangência das UBS, conhecendo o território e as comunidades, levantando os principais problemas de saúde da região, selecionando um deles para estudo e desenvolvimento de propostas de intervenção" (UNIVERSIDADE, 1999d).

No segundo ano previa-se ser possível combinar a participação de estudantes de medicina e de enfermagem em atividades voltadas para o individual e para $o$ coletivo, para a prática clínica e para a saúde coletiva através do acompanhamento dos programas desenvolvidos nas unidades básicas de saúde.

Um outro espaço de definição sobre o conteúdo das práticas é o módulo de habilidades, cujas atividades são programadas para cada grupo tutorial,

\footnotetext{
${ }^{4}$ Esse panorama foi se alterando progressivamente. A Enfermagem, em sua nova proposta curricular, também preservou o espaço multiprofissional de ação na comunidade e nos serviços ao longo de toda a carreira. Assim o PIN 1/PEEPIN reúne estudantes de todas as carreiras da saúde e os módulos subseqüentes (PIN2, 3 e 4) são trabalhados pelos estudantes de medicina e enfermagem articuladamente.
} 
dependendo das características próprias de cada conjunto de habilidades a serem trabalhadas pelos estudantes.

O programa de capacitação é estruturado anualmente tendo em vista as competências e habilidades esperadas. Como exemplo, no primeiro ano são previstas as seguintes competências e habilidades:

Figura 13- Desempenhos e habilidades a serem desenvolvidos ao longo do primeiro ano do curso de medicina da UEL.

\begin{tabular}{|c|c|c|}
\hline Área & Desempenlios & Habilidades \\
\hline $\begin{array}{l}\text { Acesso à } \\
\text { Informação }\end{array}$ & $\begin{array}{l}\text { Acessar infor maçōes } \\
\text { bibliográficas e eletrônicas }\end{array}$ & $\begin{array}{l}\text { - Utilizar biblioteca; } \\
\text { - Acessar informações via internet; }\end{array}$ \\
\hline Semiologia & $\begin{array}{l}\text { - } \\
\text { anaconhecer os topismos } \\
\text { Dominar as técnicas de verificação } \\
\text { dos sinais vitais; } \\
\text { - Conhecer as técnicas elementares } \\
\text { de semiotécnica no exame físico } \\
\text { geral e segmentar.; } \\
\text { Dominar a sistematização das } \\
\text { etapas do exame físico }\end{array}$ & $\begin{array}{l}\text { - Identificação das sintopias; } \\
\text { - } \quad \text { Verificar com proficiência os sinais vitais; } \\
\text { - Demonstrar conhecimentos na capacidade de } \\
\text { realizar } \\
\text { o exame físico - inspeção, palpação, percussão e ausculta } \\
\text { - } \\
\text { em adulto normal. } \\
\text { - Identificar as fases do exame físico geral e } \\
\text { segmentar. }\end{array}$ \\
\hline $\begin{array}{l}\text { Comunica } \\
\text { cão }\end{array}$ & $\begin{array}{l}\text { - Reconhecer atitudes facilitadoras } \\
\text { para a relação médico-paciente; } \\
\text { Realizar técnicas básicas de } \\
\text { entrevista }\end{array}$ & $\begin{array}{l}\text { - Reconhecer a importância da comunicação verbal e } \\
\text { não } \\
\text { verbal na relação médico-paciente; } \\
\text { - Diferenciar as reações do paciente frente à doença; } \\
\text { - Reconhecer atitudes adequadas e inadequadas frente } \\
\text { ao } \\
\text { paciente; saber avaliar as próprias emoções frente a } \\
\text { diferentes } \\
\text { situações; } \\
\text { - Reconhecer a importância do toque (contato físico); } \\
\text { - Desenvolver a capacidade de observar e ouvir; } \\
\text { - Formular perguntas abertas de comunicação simples. }\end{array}$ \\
\hline $\begin{array}{l}\text { Procedimen- } \\
\text { tos }\end{array}$ & $\begin{array}{l}\text { - } \quad \text { Realizar alguns procedimentos } \\
\text { básicos à prática médica..: } \\
\text { Praticar a reanimação cardio } \\
\text { pulmonar em condições de } \\
\text { ambiente extra-hospitalar. }\end{array}$ & $\begin{array}{l}\text { - } \quad \text { Dominar a técnica de lavagem de mãos. } \\
\text { - Realização de curativos simples. } \\
\text { - Realização das técnicas do suporte básico de vida } \\
\text { (BLS). }\end{array}$ \\
\hline
\end{tabular}




\begin{tabular}{|c|c|c|}
\hline Área & Desemipenlios & Habilidades \\
\hline $\begin{array}{l}\text { Exames } \\
\text { complemen- } \\
\text { tares }\end{array}$ & $\begin{array}{l}\text { - } \quad \text { Saber atuar em laboratórios de } \\
\text { apoio diagnóstico. } \\
\text { - } \quad \text { Correto manuseio do microscópio. } \\
\text { Realizar algumas dosagens por } \\
\text { equipamentos laboratoriais } \\
\text { portáteis. } \\
\text { - Conhecimento da anatomia } \\
\text { normal através dos exames de } \\
\text { imagem. } \\
\text { Conhecimentos básicos de } \\
\text { eletrocardiografia. }\end{array}$ & $\begin{array}{l}\text { - Realizar procedimentos de apoio diagnóstico de } \\
\text { acordo } \\
\text { com normas de biossegurança } \\
\text { - Utilização básica de proteção individual (EPIs). } \\
\text { - Descarte de materiais químicos e biológicos. } \\
\text { - Utilização correta de equipamentos de } \\
\text { - Condioproteção; } \\
\text { ambiente hospitalar e laboratorial. } \\
\text { - Dosagens de glicemia, hemoglobina e urinálise por } \\
\text { fita. } \\
\text { - Identificar as estruturas anatômicas normais nos } \\
\text { exames } \\
\text { de imagem (radiologia convencional, ultra-sonografia, } \\
\text { emografia } \\
\text { e ressonância nuclear magnética); } \\
\text { - Reconhecer o traçado eletrocardiográfico normal. }\end{array}$ \\
\hline
\end{tabular}

Fonte: $2^{\circ}$ Workshop de Habilidades no currículo de medicina da UEL, julho de 1999 (UNIVERSIDADE,1999e).

Apesar de haver a possibilidade de desenvolvimento dessas habilidades em múltiplos cenários, a maior partes das atividades para o 1ªno em 1998 estavam previstas para serem realizadas no Laboratório de Habilidades, no Ambulatório do Hospital das Clínicas, no ambulatório do Hospital Universitário, em salas de aula e laboratórios do Centro de Ciências Biológicas, no Núcleo de Informação em Saúde (NIS) (UNIVERSIDADE, 1998a).

Como já comentado, os módulos eletivos também são potencialmente um espaço definidor de conteúdos de práticas. Nos primeiros dois anos de funcionamento do novo curso, as ofertas mais procuradas pelos estudantes foram as "imersões clínicas".

Em 1998 e em 1999, essa imersão possibilitou aos alunos o acompanhamento e a observação de todo tipo de atendimento prestado nos diferentes setores clínicos de um grande hospital terciário filantrópico da cidade. Em 1999, a imersão clínica incluiu o acompanhamento, pelos estudantes do segundo ano, de todas as atividades profissionais de alguns médicos da cidade. Em todos os casos os estudantes tiveram que elaborar um relatório detalhado sobre todas as atividades desenvolvidas durante o estágio. 
Um outro espaço de definição do conteúdo das práticas são os próprios módulos - que programam atividades voluntárias de acordo com seus conteúdos. Como exemplo, seguem algumas das atividades práticas previstas em alguns dos módulos do $1^{\circ}$ e do $2^{\circ}$ ano:

- Módulo Introdução ao estudo da Medicina: aprender a utilizar a biblioteca; aprender conceitos básicos de informática e internet; conhecer os diferentes níveis de atenção à saúde; conhecer técnicas e atitudes de comunicação; desenvolver espírito crítico em relação à comunicação (UNIVERSIDADE, 1998b).

- Módulo Concepção e Formação do Ser Humano: observação de modelos e peças anatômicas e de embriologia; observações de lâminas de histologia; aprender a realizar teste de gravidez; experimento prático de fisiologia da reprodução - todas previstas para laboratórios (UNIVERSIDADE, 1998c);

- Módulo Metabolismo: observação de modelos e peças anatômicas; observações de lâminas de histologia; aprender a realizar interpretação de dados laboratoriais de dosagens de lipídeos, colesterol e frações; estudo da ação de enzimas; experimento prático de fisiologia da digestão - todas previstas para laboratórios (UNIVERSIDADE, 1998d);

- Módulo Abrangência das Ações de Saúde: análise de depoimentos sobre mercado de trabalho e papel do médico; valor preditivo positivo e negativo, sensibilidade e especificidade, relação custo/benefício; visita ao SIATE (Sistema de Atenção ao Trauma e às Emergências) para conhecer funcionamento do serviço e sistema de informação; visita ao CCI (Centro de Controle de Intoxicação) para conhecer objetivos, serviços e clientela do CCI, saber como ele se articula com os outros serviços de saúde e conhecer os principais acidentes peçonhentos e intoxicações (UNIVERSIDADE, 1998e);

- Módulo Nascimento, Crescimento e Desenvolvimento: observação de modelos e peças anatômicas; observações de lâminas de histologia - ambas em laboratórios; ambulatório de puericultura (HU); ambulatório de obstetrícia 
normal (HU); observação de pré-parto, parto normal e puerpério na Maternidade Municipal (UNIVERSIDADE, 1999a);

- Módulo Proliferação celular: atividades práticas integradas (biologia celular e microbiologia em laboratório): crescimento celular in vitro, divisão, diferenciação e morte celular; ambulatório de ginecologia - preventivo ce câncer ginecológico; atividade prática integrada (patologia e histologia em laboratório): características diferenciais entre tumores malignos e benignos, lesões de pele malignas e benignas, lesões pré-neoplásicas e neoplásicas de pulmão; visita ao Instituto do Câncer de Londrina (UNIVERSIDADE, 1999b);

- Módulo Processo de Envelhecimento: identidade e dignidade do idoso no Ambulatório do Hospital Universitário; potencial oxidativo das membranas biológicas e envelhecimento no laboratório de patologia; envelhecimento tecidual da pele no laboratório de histologia; visita a instituições asilares de Londrina; avaliação do estado nutricional em idosos no ambulatório do $\mathrm{HU}$; exercício físico e reabilitação no Serviço de Fisioterapia do HU; "Saber envelhecer" co o Grupo de Teatro da Terceira Idade do SESC; prática clínica no ambulatório do $\mathrm{HU}$; anatomia do envelhecimento no laboratório de anatomia. (UNIVERSIDADE, 1999c).

\subsubsection{A avaliação}

\subsubsection{Avaliação do aluno:}

Segundo a nova proposta, para que a avaliação pudesse atingir sua finalidade educativa, ela deveria ser coerente com os princípios psicopedagógicos e sociais do processo de ensino-aprendizagem. Além disso, ela deveria ser compreendida como um processo dinâmico que serviria para orientar a aprendizagem, facilitando que se alcançassem os resultados desejados. A avaliação deveria, portanto, representar um processo de compreensão dos avanços, limites e dificuldades que os alunos estão encontrando para atingir os objetivos propostos. 
Dessa maneira, defendia-se como essencial a adoção de modalidades formativas de avaliação, articuladas com modalidades somativas. Segundo a nova proposta,

"a avaliação formativa visa o acompanhamento do processo de aprendizagem do aluno e possibilita ao professor/tutor conhecer suas dificuldades dos alunos e, identificar o tipo de ajuda mais adequada para desenvolver suas potencialidades. A avaliação somativa ajudará o professor/tutor a identificar a aprendizagem efetivamente ocorrida" (UNIVERSIDADE, 1997b).

Foram propostas várias modalidades de avaliação a serem utilizadas no novo currículo, dentre as quais, as mais significativas são as seguintes:

- "Autoavaliação: é a avaliação realizada pelo aluno sobre o seu próprio desempenho. Esta avaliação deve englobar a monitoramento do seu conhecimento, atitudes e habilidades, ajudando o aluno a reconhecer e assumir mais responsabilidade em cada etapa do seu processo de aprendizagem".

- Avaliação interpares: é a avaliação realizada pelos membros do grupo sobre o desempenho de cada um dos participantes.

- Avaliação pelo tutor: para identificar as habilidades e progresso de cada aluno durante as sessões grupais.

- Resolução de problemas do paciente (Patient Management Problems - PMP): este tipo de avaliação oferece ao aluno a oportunidade de demonstrar sua habilidade em tomar condutas frente ao problema do paciente. A questão é apresentada em quatro fases: a) informações sobre o paciente; b) ação do aluno; c) "feedback"; d) conclusão do problema.

- Avaliação baseada no desempenho clínico: a avaliação de habilidades clínicas específicas constitui um componente essencial da avaliação da competência médica. O método denominado de Exame Clínico Objetivo Estruturado (Objetive Structured Clinical Examination - OSCE) é organizado com base em um número variado de estações com emprego de diversos materiais e recursos (exames, peças, pacientes, vídeos, etc), possibilitando a garantia de maior objetividade e padronização das condições de avaliação.

- Questōes de ensaio modificadas (Modified Essay Questions - MEQ): consiste em uma série de questōes relacionadas a um problema de saúde. A informação sobre o caso é apresentada em estágios sucessivos.

- Teste progressivo: consiste em uma bateria de testes tipo verdadeiro-falso, onde o aluno deve assinalar uma das três alternativas ( $V, F$ ou ?), esta última opção pode ser assinalada numa situação em que o aluno não tem certeza se a questão é verdadeira ou falsa. Este teste é 
elaborado para fornecer uma avaliação longitudinal do progresso do aluno durante o curso. Avaliam-se os conhecimentos adquiridos em todas as áreas das ciências médicas consideradas pertinentes à formação profissional. O teste pode ser aplicado várias vezes ao ano a todos os alunos do curso" (UNIVERSIDADE, 1997b).

Essas modalidades poderiam ser usadas de acordo com os objetivos da avaliação a cada momento, como mostram as Figuras 14 e 15:

Figura 14 : Possibilidades de utilização de técnicas, segundo avaliação formativa ou somativa, no curso de medicina da UEL.

\begin{tabular}{|c|c|}
\hline Formativa: & Somativa: \\
\hline - Autoavaliação & - OSCE \\
\hline - Avaliação interpares & - Resolução problema paciente (PMP) \\
\hline - Avaliação pelo tutor & - Questões ensaio modificadas (MEQ) \\
\hline - Teste progressivo & - Múltipla escolha \\
\hline
\end{tabular}

Fonte: Novo currículo do curso de medicina (UNIVERSIDADE, 1997 b)

Figura 15: Possibilidades de utilização de técnicas segundo áreas a serem avaliadas no curso de medicina da UEL.

\begin{tabular}{|l|c|c|c|}
\hline Método & & & Cognitivo \\
\hline Autoavaliação & & & $X$ \\
\hline Avaliação interpares & & & $X$ \\
\hline Avaliação pelo tutor & $X$ & & $X$ \\
\hline PMP & $X$ & $X$ & \\
\hline OSCE & $X$ & & \\
\hline MEQ & $X$ & & \\
\hline Múltipla escolha & $X$ & & \\
\hline Teste progressivo & $X$ & & \\
\hline
\end{tabular}

Fonte: Novo currículo do curso de medicina (UNIVERSIDADE, 1997 b)

Pretendia-se utilizar as várias modalidades com periodicidades distintas: semanalmente, seriam feitas a autoavaliação, avaliação interpares e pelo tutor; a cada módulo, todas elas, com exceção do teste progressivo, que pretendia ser semestral. A avaliação cognitiva também estava prevista para o final de cada módulo.

No Manual do Estudante apresenta-se o seguinte sistema de aprovação dos alunos: a avaliação formativa tem peso 5 (1 para autoavaliação, 1 para avaliação interpares e 3 para avaliação pelo tutor); a avaliação somativa tem peso 5 ( 2 para a avaliação cognitiva ao final de cada módulo e 3 para a avaliação de habilidades e atitudes ao final de cada módulo) (THOMSON \& LIMA, 1998). 
A conversão da escala de pontuação para nota é feita através da multiplicação do escore obtido por 2. Os critérios de aprovação e reprovação são os determinados pela UEL: aprovação sem exame (média igual ou maior que 7), aprovação com exame (média igual ou maior que 5), dependência para o aluno que obtiver qualquer tipo de aprovação em até 2 módulos e reprovação para o aluno que não obtiver qualquer tipo de aprovação em 3 ou mais módulos (THOMSON \& LIMA, 1998).

\subsubsection{Avaliação do currículo:}

Pretendia-se desenvolver um sistema de monitoramento contínuo do currículo, utilizando as informações obtidas através das avaliações realizadas pelos alunos, pelos tutores e por outros docentes a respeito do processo de implementação curricular, da qualidade dos problemas, dos módulos, do trabalho do tutor, dos recursos disponíveis (biblioteca, laboratórios, etc).

Essas informações seriam coletadas através de questionários específicos para cada item avaliado, com questões fechadas e abertas, com periodicidade adequada, a ser definida posteriormente.

As informações deveriam ser objeto de análise pela Comissão de Avaliação e pela Comissão de Acompanhamento servindo para correção de rumos, de melhoria nos módulos e nos problemas (UNIVERSIDADE, 1997 b).

\subsubsection{A gestão do processo de mudança}

Desde que foi criado, particularmente a partir de 1994, o Colegiado do Curso de Medicina funcionou muito bem como elemento catalisador dos processos de avaliação do curso, de construção e experimentação de inovações metodológicas, de articulação interdisciplinar e de diversificação de cenários de aprendizagem.

Desde o Seminário de Avaliação do Currículo Seriado, realizado em agosto de 1996, o Colegiado mostrou-se também um instrumento eficaz para a construção participativa de 
um novo currículo. Essa postura credenciou-o para as tarefas de gerenciamento acadêmico-administrativo do novo currículo.

No entanto, considerando as características centrais do currículo proposto, identificaram-se novas complexidades gerenciais que deveriam ser assumidas solidariamente, em termos cooperativos, pelo Colegiado, pelas direções do CCS e do CCB e por vários outros atores. Entre esses, destacaram-se chefias de Departamentos, coordenadores de Setor, coordenações de disciplinas e vários organismos de apoio, como o Núcleo de Apoio Pedagógico do CCS (NAP), o Núcleo de Estudos de Saúde Coletiva (NESCO), a Biblioteca setorial do CCS e os Laboratórios de Informática (NIS) e de Habilidades (UNIVERSIDADE, 1997 b).

A tarefa não era pequena, nem simples. Seria necessário, ao longo de 4 anos, gerenciar paralelamente duas estruturas curriculares: uma crescente (a nova) e outra decrescente (a velha). Considerando a prática freqüente de mudanças curriculares em Londrina, já havia um certo conhecimento acumulado a respeito, mas nunca se havia enfrentado uma mudança tão radical, em que se criavam novos fazeres e se extinguiam outros, em que a ação de coordenação era essencial, em que se rompiam mecanismos tradicionais de distribuição de poderes e fazeres.

Foram criadas novas estruturas para realizar algumas tarefas fundamentais do novo currículo: Comissão de Avaliação, Comissão de Habilidades, Comissão de Treinamento. Para cada série que se implantava, foi instituído um coordenador de série e para cada módulo a ser construído um coordenador, encarregado de reunir um grupo de docentes para a construção dos problemas e outro grupo para assumir a função de tutoria. Criou-se também uma Comissão de Implantação e Acompanhamento, que reunia coordenador e vice-coordenador do colegiado, os coordenadores das novas comissões e, progressivamente, os coordenadores de série, os coordenadores de módulo em implantação e um representante discente, que estava encarregada de coordenar a implantação do novo currículo. 


\subsection{O que aconteceu na prática}

O novo currículo foi sendo implantado com muito entusiasmo. O ritmo de trabalho e a mobilização eram muito intensos; grande a participação e o interesse na construção dos módulos; a capacitação de tutores estava funcionando a todo vapor.

Inicialmente foi fundamental a intensa participação dos docentes do curso básico em todas as atividades do novo currículo. Comportamento esse já esperado, pois havia uma percepção generalizada a respeito da maior adesão dos professores do básico às propostas de mudança (provavelmente fruto de sua adesão às estratégias de sensibilização) e de maior resistência na área clínica (desde a aprovação da nova proposta, uma das tarefas identificadas pelo Colegiado era ativamente conquistar novas adesões nessa área) (UNIVERSIDADE, 1999f).

A próxima figura ilustra a participação dos docentes dos vários departamentos nas atividades de cada série do novo currículo ao longo dos primeiros 4 anos da implantação. Essa participação pode se dar na organização e no planejamento de módulos, na tutoria dos módulos, no programa de habilidades (como planejador e como instrutor) ou nos PINs (como planejador e como instrutor) e nas atividades práticas dos módulos. Um mesmo docente pode participar de várias delas. 
Figura 16. Número de docentes e de participações nas atividades do novo curso de medicina por departamentos do CCS ou centros da UEL de 1998 a 2001.

\begin{tabular}{|c|c|c|c|c|c|}
\hline Departamento & $\begin{array}{l}\text { No. de } \\
\text { docentes }\end{array}$ & $\begin{array}{l}\text { Participaçōes } \\
\text { no } 10 \text { ano }\end{array}$ & $\begin{array}{l}\text { Participaçōes } \\
\text { no } 2^{\circ} \text {. ano }\end{array}$ & $\begin{array}{l}\text { Participaçôes } \\
\text { no } 3^{\circ} \text {.ano }\end{array}$ & $\begin{array}{l}\text { Participaçòes } \\
\text { no } 4{ }^{\circ} \text { ano }\end{array}$ \\
\hline Histologia & 5 & 14 & 10 & 8 & 3 \\
\hline Microbiologia & 7 & 16 & 8 & 10 & 1 \\
\hline Patologia & 13 & 21 & 9 & 6 & 0 \\
\hline Bioquímica & 4 & 7 & 1 & 1 & 2 \\
\hline COP & 1 & 0 & 0 & 0 & 1 \\
\hline Matemática & 2 & 4 & 1 & 0 & 0 \\
\hline Química & 1 & 0 & 1 & 0 & 0 \\
\hline CESA & 2 & 0 & 2 & 1 & 1 \\
\hline $\mathrm{CCH}$ & 2 & 6 & 6 & 2 & 0 \\
\hline CTU & 1 & 0 & 1 & 0 & 0 \\
\hline Odontologia & 1 & 0 & 1 & 0 & 0 \\
\hline Enfermagem & 1 & 1 & 0 & 0 & 0 \\
\hline Fisioterapia & 4 & 0 & 1 & 0 & 3 \\
\hline PALD & 10 & 9 & 13 & 12 & 9 \\
\hline Cirurgia & 58 & 7 & 16 & 19 & 20 \\
\hline Clínica Médica & 89 & 58 & 54 & 82 & 80 \\
\hline MISC & 49 & 33 & 45 & 28 & 14 \\
\hline
\end{tabular}

Fonte: Relatório preparado para visita de Avaliação das Condiçð̌es de Oferta em 1999 e atualizado em 2001 (UNIVERSIDADE, 2001).

Sem dúvida, a participação dos professores do básico na implantação da mudança foi crucial. A Figura 17 ilustra a participação dos docentes na função de tutor:

Figura 17. Participação dos docentes na função de tutores por departamentos do CCS ou Centros nos quatro primeiros anos de implementação do novo currículo de medicina da UEL.

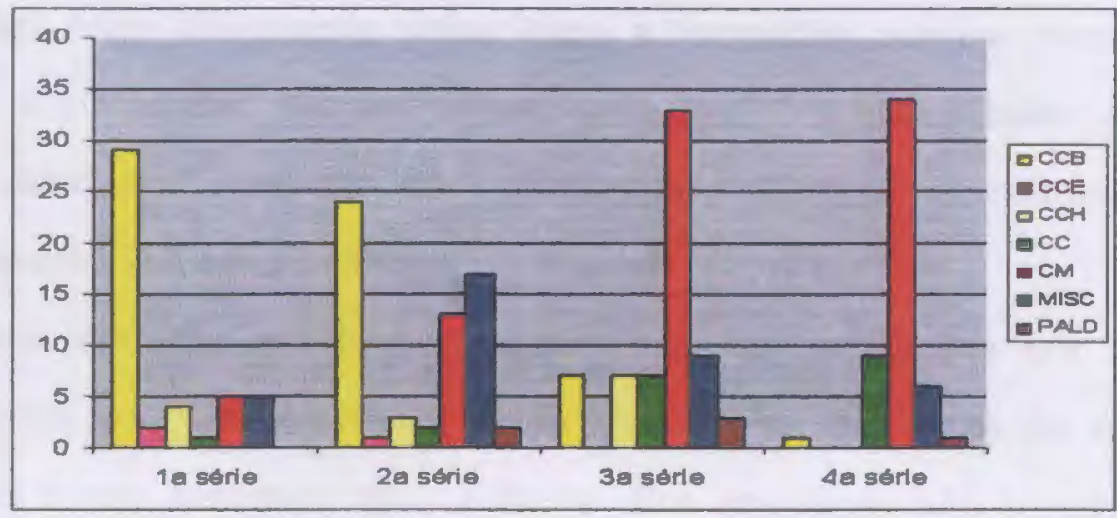

Fonte: Cadernos dos módulos da 1". à 4" série. 
Ao longo do tempo, o número de professores favoráveis à nova proposta - e efetivamente participantes - ampliou-se. Diante de uma consulta avaliando a adoção da aprendizagem baseada em problemas, $62 \%$ dos docentes consideram-na um avanço, $25 \%$ ficam neutros e somente $10 \%$ consideram-na um retrocesso. $87 \%$ dentre os docentes consultados consideram melhor a qualidade do ensino oferecido atualmente e que nesta nova proposta os estudantes estão mais motivados para aprender (AGUIAR,2001).

Mas, como já mencionado anteriormente, não foram desenvolvidas estratégias específicas para a mobilização dos clínicos, então sua adesão ao novo currículo foi sendo conquistada no cotidiano, por pressão administrativa - e não motivada por uma reflexão crítica acerca das práticas e concepções tradicionais.

Como a integração dos novos docentes ao novo currículo aconteceu principalmente através do planejamento dos módulos e das tutorias (a parte especificamente de aplicação da metodologia baseada em problemas), pode-se dizer que uma parte dos docentes aderiu a uma mudança metodológica e não a uma proposta de formação de um profissional com outro perfil e outras competências.

Em 1999, por exemplo, em pesquisa respondida por metade dos docentes do CCS (portanto excluídos os docentes do básico), $46 \%$ não tinham opinião formada a respeito da importância do PIN, enquanto $44 \%$ consideravam que essas atividades eram de grande valor para a formação médica (somente 1 docente afirmou o contrário). Nessa mesma consulta, 61\% não sabiam como operavam esses módulos e somente $24 \%$ souberam informar corretamente como eles funcionavam (TURINI, 2000).

Essa situação produz conseqüências. Há limitações em alguns aspectos importantes do novo currículo, especialmente na dinâmica do quarto ano e do internato, como veremos mais adiante. Por enquanto são tropeços e limitações impostos pela dificuldade de fazer algo totalmente novo e também pela dinâmica 
política do processo, mas, se não enfrentadas adequadamente, podem chegar a comprometer a profundidade e a coerência da proposta de mudança.

\subsubsection{O projeto político-pedagógico}

A nova proposta implica mudanças profundas no papel do professor e do estudante no processo de ensino-aprendizagem, no papel dos departamentos e das disciplinas, tanto na definição dos conteúdos a serem incluídos como na operacionalização do processo, na intensificação da presença dos estudantes nos novos cenários de ensino-aprendizagem. Busca-se transformar o perfil do médico formado, que deveria ser "melhor preparado para inserção na realidade médico-sanitária brasileira" (TURINI,2000).

Essa também é a opinião dos atores participantes do processo, que quando perguntados a respeito de qual a principal característica da nova proposta curricular, destacaram: "interdisciplinaridade", "centrado no aluno", "desenvolver a capacidade de buscar o próprio conhecimento", "formar profissional mais humano e preparado para lidar com a dor e o sofrimento", "a questão da humanização, de como atender o outro, da questão da relação médico-paciente, como estabelecer o vínculo e tal". (grupo focal dos docentes L).

Os estudantes disseram que a principal característica do novo currículo é: "independência do aluno", "desenvolver espírito crítico", "conhecer bem a realidade prática", "saber buscar o conhecimento", "aprender a lidar com as pessoas". (Grupo focal de estudantes L)

Os professores das outras carreiras, os profissionais dos serviços e a comunidade disseram que a principal característica do novo curso é "a interação ensino-serviço-comunidade porque dá aos estudantes uma visão mais ampla da realidade", "maior capacidade crítica", "raciocínio mais integrado, concepção integral da pessoa" (Grupo focal de outras carreiras, profissionais dos serviços e comunidade L)

De fato, houve mudanças profundas no papel dos departamentos e também no papel das disciplinas, especialmente em relação à definição do conteúdo a ser 
incluído na graduação. Os conteúdos a serem trabalhados nos módulos são debatidos, discutidos, negociados por grupos de trabalho constituídos por professores de várias disciplinas, orientados pela árvore temática de cada módulo.

É verdade que o currículo nuclear está sendo construído assim, na prática, em cada módulo, pois não foi possível ainda realizar o trabalho global de definição dos conteúdos (parece ser mais factível negociar ponto a ponto, caso a caso, em cada módulo do que fazer uma negociação global, que poderia ser paralisante). Portanto, será importante dentro de algum tempo fazer um balanço geral para identificar com precisão o perfil que está sendo criado e ajustá-lo às pretensões da proposta de mudança (Entrevistado L2).

Houve também mudanças radicais no papel de docentes e estudantes no processo de ensino-aprendizagem. Os estudantes ganharam autonomia, independência, visão integrada e capacidade de proposição.

“No seminário que eles (os estudantes) fizeram no dia 20/21 (de novembro de 2000), eles mostraram sinais de maturidade de discussão e uma capacidade de organização. Você viu o relatório? Está muito melhor que o nosso. Coisas coerentes, reais, que são factiveis" (Entrevistado L2).

São muito críticos em relação a tudo: ao processo de ensino-aprendizagem, ao comportamento dos docentes e dos profissionais de saúde etc.

"Comparando com estudantes de outros cursos, eles (os alunos da medicina) desenvolvem uma maior capacidade de critica...de avaliar o que eles realmente aprendem, o tipo de trabalho que está sendo desenvolvido.." (grupo focal das outras carreiras, profissionais dos serviços e comunidade L).

“Então eles não estão lá - gente do primeiro e do segundo ano - só olhando como eu estou atendendo o paciente. Eles falam a respeito do que estão estudando, articulam os conhecimentos, pensam na fisiopatologia, na histologia ...avaliam a relação médico-paciente ... uma coisa bem integrada. Achei super-legal." (grupo focal das outras carreiras, profissionais dos serviços e comunidade $\mathrm{L}$ ). 
"Para o professor também é um choque porque o aluno vai participar mais, exigir mais...vai cobrar muito mais do professor. Eles cobram outros aspectos, não só da doença, especialmente em relação a uma atenção maior com o paciente" (grupo focal das outras carreiras, profissionais dos serviços e comunidade L).

É com base em sua ação crítica que muitos problemas vem sendo enfrentados e corrigidos.

"...cabe ao aluno buscar o próprio conhecimento..cabe a ele buscar tudo que quer" (grupo focal dos estudantes L)

"Acho que a gente nunca fez tanto abaixo-assinado na vida...porque a gente tá procurando justamente sempre melhorar o curso. A gente gosta muito do PBL....Um dia fizemos um questionário para medir a satisfação dos estudantes e é grande... mas a gente acha que tem coisas que precisam ser mudadas." (grupo focal dos estudantes L)

" a gente reclamou, reclamou e mudou. (a dinâmica do laboratório de anatomia)" (grupo focal dos estudantes L).

" a gente sabe o que se passa, quem é bom, quem é ruim, quem está dando certo e que não está. Agora, especialmente em relação aos professores, as decisões são lentas, há problemas que já foram identificados desde o primeiro ano...e continuam lá..." (grupo focal dos estudantes L).

"outra coisa que já está cansando, principalmente a primeira turma, é que a gente batalha, batalha, mas as mudanças são sempre para os outro, para a próxima turma. Precisava haver mais agilidade para nós também sairmos ganhando" (grupo focal dos estudantes L).

E os professores apesar de terem "que lutar" contra os velhos hábitos, no geral estão mais satisfeitos com o processo muito mais dinâmico de trabalho e mais intenso de relação com os estudantes: mais interessante, mais estimulante, mais efetivo, mais gratificante.

“Essa nova proposta trouxe uma oportunidade impar para que uma comunidade cada vez mais crescente de docentes participem da discussão gerencial do currículo. Se procura entender as coisas de maneira global. Foi 
um avanço muito grande. Cada vez mais vão se criar aqui pessoas ou lideranças capazes de entender e tratar a questão da formação como ela merece" (grupo focal de docentes L).

"quando você centra a discussão nos alunos, quando a discussão é feita pelos próprios estudantes, o papel do tutor realmente é outro" (grupo focal de docentes $\mathrm{L}$ ).

“...você tirou totalmente o poder... ou tirou muito o poder daquele professor em resolver o destino do aluno, em termos de nota, né..." (grupo focal de docentes L).

“ como tutor, ele vai fazer avaliação, mas ele não é todo-poderoso para definir, porque há outras coisas como a autoavaliação, uma avaliação do próprio grupo de estudantes, uma avaliação cognitiva interdisciplinar ..." (grupo focal de docentes L).

“...isso (a perda do poder) é uma diferença nessa linha de característica principal do processo: é um deslocamento extremamente significativo" (grupo focal de docentes L).

“ a gente está mais próximo deles, pode fazer mais diferença. Vários alunos tiveram uma melhora na sua atitude, no seu comportamento. Por exemplo, eu tive um aluno tímido que não falava quase nada e agora se expressa muito bem, consegue se expor" (grupo focal de docentes L).

A nova proposta curricular, portanto, configura novos espaços e novas relações de poder, novos papéis e muitos desafios. Especialmente porque, nessa construção, nem todas as respostas estão dadas e nem todas as ferramentas necessárias disponíveis. E o conflito e a disputa fazem parte do processo, pois há vários pontos de tensão e divergência.

Logo após a aprovação do currículo, ainda no processo de construção dos módulos e do modus operandi, iniciou-se o primeiro conflito, que girou em torno da obrigatoriedade ou não do módulo de interação ensino-serviço-comunidade.

Algumas pessoas na Comissão de Implantação defendiam que essas atividades, bem como a capacitação em habilidades, deveriam ser opcionais. Os 
argumentos fundamentais eram de duas naturezas: uma, dita "metodológica" fossem obrigatórias essas atividades, ficaria demasiadamente reduzido o tempo livre dos estudantes para o estudo independente - e outra dita "circunstancial e política" - pois não haveria condições adequadas nas unidades de saúde para a prática dos estudantes e seria muito instável a parceria com os serviços em razão das freqüentes transições políticas (TURINI, 2000).

No entanto, prevaleceu a posição de que essas atividades eram parte central da "alma" da nova proposta de formação, pois seria principalmente através delas que se garantiria aos estudantes a oportunidade de trabalhar nos cenários reais, de maneira multiprofissional e em estrita relação com os profissionais dos serviços e com a comunidade. E foi o Colegiado de Curso, composto por representantes de todos os departamentos, a instância que reafirmou a obrigatoriedade dos PINs.

Ainda assim, no processo de implantação do novo currículo a ênfase em relação aos seus vários aspectos foi heterogênea. Por várias razões, houve maior ênfase no aspecto da mudança metodológica que em relação aos demais aspectos tanto que o novo currículo ficou conhecido entre docentes e estudantes como "PBL". A principal razão era que era mais fácil convencer os professores em relação a uma alternativa metodológica mais ativa e a uma organização integrada dos conhecimentos - porque havia descontentamento em relação a esses aspectos no currículo tradicional. Mas houve quem de fato encarasse a mudança como restrita ao aspecto metodológico (TURINI, 2000).

Para garantir a amplitude e a profundidade da mudança, não basta somente a disposição do Colegiado, que considera que o valor mais importante que cada um tem para oferecer ao processo de formação dos estudantes de medicina é "passar as informaçōes; buscar novas relações - ética; sempre ter entusiasmo/esperança; formar o médico para a comunidade - responsabilidade social; experiência vivida; entusiasmo; trabalho e dedicação; orientação de ensino, pesquisa e formação;contribuir para que os alunos sejam bem sucedidos" (UNIVERSIDADE, 1999f) 
O estudo de TURINI (2000) colocou com muita precisão a necessidade de tratar a questão da mudança curricular de maneira mais profunda. Apesar dos importantes elementos trazidos à tona por seu trabalho terem sido divulgados amplamente, não houve conseqüências práticas.

Por várias razões - o ativismo gerado pela implantação da proposta, a orientação implementada pela direção de evitar as disputas políticas explícitas nos últimos dois anos escassearam os espaços de discussão e de formação docente. É o diagnóstico de vários dos entrevistados:

"É tudo mais complicado do que a gente imaginava no começo. Para chegar ao grau de integração e articulação que propusemos, vamos ter que caminhar muito e aprender muito... só que não dá tempo! Mas a gente deveria estar fazendo curso, estudando para poder avançar na mudança". "No ano que vem a gente tem que voltar a fazer capacitação. para poder dar um salto de qualidade em relação ao que já conseguimos implantar." "Melhor ainda se conseguirmos envolver outras pessoas novas, que surgiram no processo" (Entrevistado L2).

"No início do processo, foi uma efervescência. muita discussão, muitas oportunidades de capacitação e debate e isso foi fundamental para poder acontecer a mudança. Agora eu acho que no momento atual está faltando reflexão. O processo está sendo tocado. Precisamos de espaços para refletir, vamos mudar para cá, vamos mudar para lá." (Entrevistado L3).

"Mesmo para o trabalho da Comissão de Avaliação, está faltando mais estudo, mais preparo especifico. E no geral, não estamos conversando sobre os problemas que vão sendo apontados aqui e ali" (Entrevistado L5).

“Estamos nos achando muito sabidos. Isso é perigoso. Corremos o risco de cometer muitos erros sentados nas glórias do passado que levou à mudança" (Entrevistado L1).

A Comissão de Capacitação nesses quatro anos cumpriu maciçamente o papel de qualificar tutores, como indica a Figura 18: 
Figura 18. Capacitação de docentes para a tutoria segundo os departamentos do Centro da Ciências da Saúde da UEL em 2001.

\begin{tabular}{|l|c|c|c|}
\hline \multicolumn{1}{|c|}{ Depto } & $\mathbf{N}^{\mathbf{0}}$ total de docentes & Docentes treinados & $\%$ \\
\hline Clínica Médica & 96 & 77 & 80 \\
\hline Clínica Cirúrgica & 59 & 31 & 53 \\
\hline MISC & 62 & 32 & 52 \\
\hline PALD & 08 & 06 & 75 \\
\hline Total & 225 & 146 & 65 \\
\hline Outros centros & - & 39 & - \\
\hline
\end{tabular}

Fonte: Relatório de Avaliação do Projeto de Apoio à Reforma Curricular (UNIVERSIDADE, 2002a).

No entanto a Comissão não avançou na identificação e tratamento de outras necessidades de capacitação, que certamente surgiram ao longo da implantação. Para mudar de atitude e de concepções no terreno da prática docente, clínica e de investigação são necessários novos recursos, novos conceitos - é necessário um programa de educação permanente para os docentes.

As primeiras tentativas de convencer a Comissão de que ela poderia trabalhar com uma compreensão menos limitada do que seja a aprendizagem baseada em problemas e do que se pretende com a reforma curricular (VENTURELLI, 1999) foram recebidas de maneira resistente, geraram conflitos e muito poucas providências práticas.

No primeiro semestre de 2001, entretanto, iniciou-se a busca de alternativas através da contratação de uma consultoria para ajudar a equacionar a questão da capacitação. Na já citada investigação-ação que deu início ao processo, constatouse que a 91\% dos docentes haviam lido 6 artigos ou mais em sua área de especialização ou investigação, mas somente $21 \%$ haviam estudado educação médica com essa intensidade. E somente $29 \%$ dos docentes consideram satisfatórios seus conhecimentos nessa área (AGUIAR,2001). Ou seja, os próprios docentes têm clareza acerca da limitação de sua formação numa área que é fundamental para a profundidade das mudanças. 
No final de 2001 várias iniciativas que poderiam ajudar a superar essa limitada falta de discussão foram suspensas por conta da longa paralisação (por 5 meses) da universidade (UNIVERSIDADE, 2002a):

- $\quad$ Fórum de Avaliação

- $\quad$ Fórum de Habilidades

- Oficina de trabalho sobre módulos e currículo nuclear

- $\quad$ Aplicação do Teste Progressivo

- Discussão sobre a nova estrutura de gestão acadêmica do curso, em função do término do processo de implantação do novo currículo

- Internato médico sob a ótica das novas diretrizes curriculares

Em 2002, na retomada das atividades após a greve, a primeira oficina de trabalho organizada pela nova coordenação do colegiado identificou como problemas críticos a serem trabalhados: a gestão, a capacitação docente, a adesão dos docentes e a avaliação dos estudantes e do programa. Resta ver se serão capazes de desenvolver estratégias adequadas.

\subsubsection{A concepção de currículo}

A interdisciplinaridade foi um dos aspectos em que mais se avançou segundo os docentes:

"Realmente avançamos nesse aspecto. O processo de construção dos módulos envolve muita discussão e troca de idéias entre representantes de uma série de disciplinas" (grupo focal dos docentes L).

"Não que as negociações sejam tranqüilas. Há sempre conflito porque o ponto de vista dos clínicos e dos professores da área básica é sempre muito distinto, mas vamos avançando, definindo realmente o que é central para uma boa formação geral do médico" (grupo focal dos docentes L).

"Antigamente entre o básico e o clínico, nós tínhamos uma 'paquerinha': a integração básico-clínico era uma musa 'bonitona'. Agora acho que efetivamente casamos. Vivemos alguns problemas, já passou a fase romântica e agora é aquela coisa do dia-a-dia. Mas os compromissos e o compartilhar são inegáveis" (Grupo focal dos docentes L). 
A coordenação dos módulos e a composição dos grupos de planejamento dá uma boa idéia desse esforço de integração:

Figura 19. Participação dos docentes, segundo departamentos do CCS ou Centros, na coordenação dos grupos de planejamento dos módulos da 1a à $4^{a}$ série do curso de medicina da UEL.

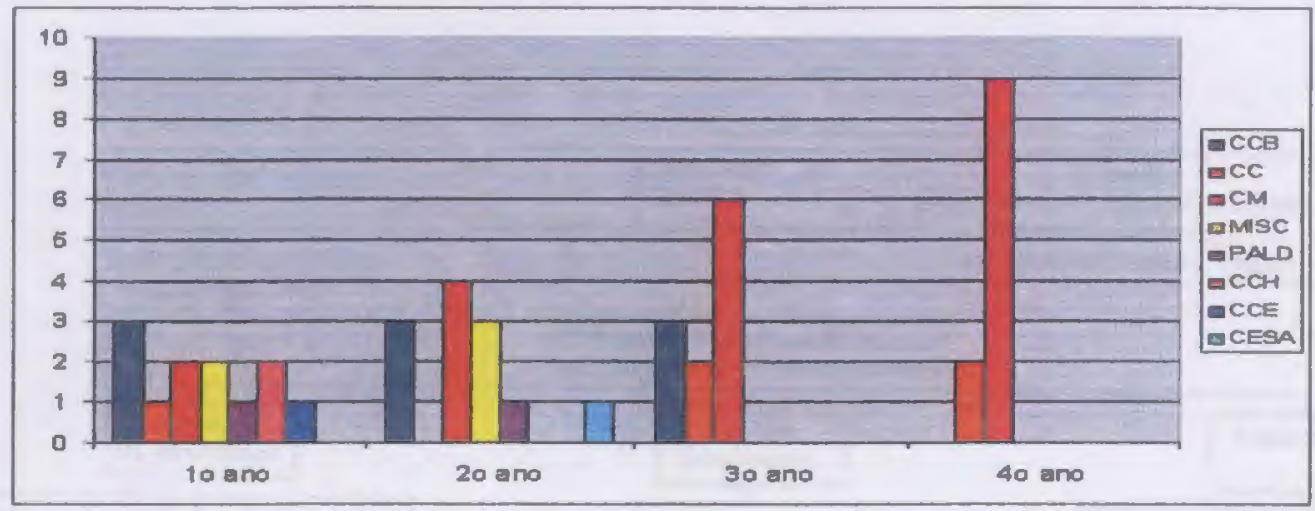

Fonte: Manuais dos módulos da 1a à 4a". séries.

Figura 20. Participaçāo dos docentes, segundo departamentos do CCS ou Centros, nos gruposde planejamento dos módulos da 1ª̀ à série do curso de medicina da UEL

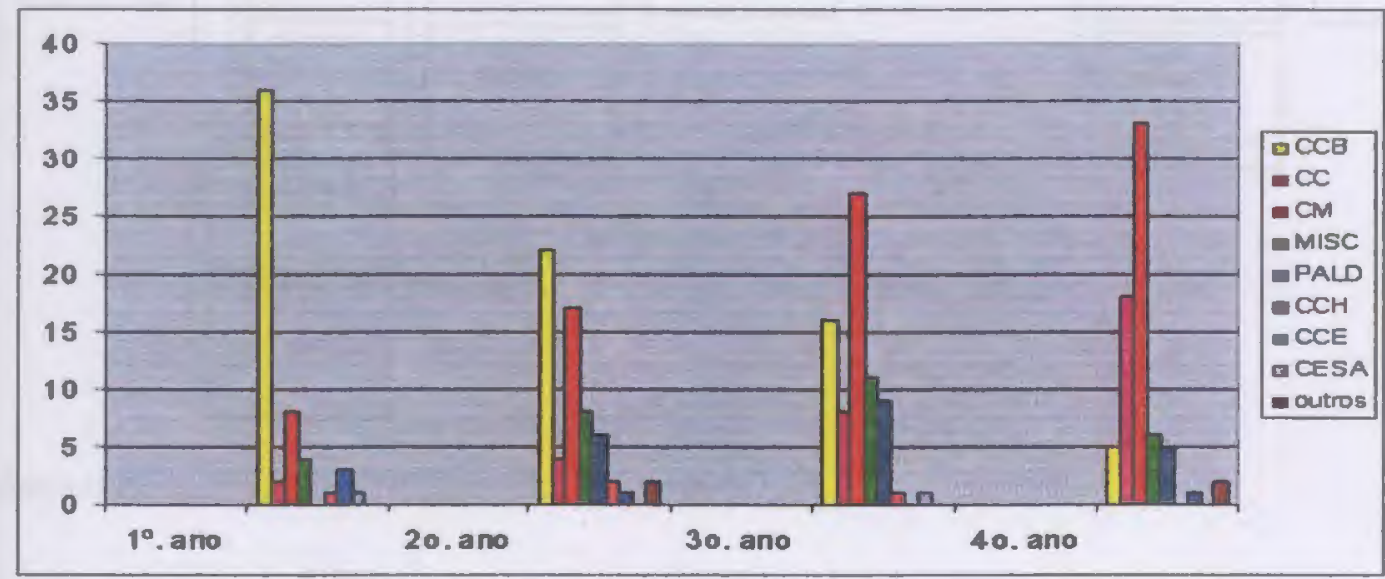

Fonte: Manuais dos módulos da 1a. à 4a. séries.

O trabalho dos grupos de planejamento se dá primeiro em torno da construção da árvore temática, através da qual se definem os temas nucleares para 
abordagem da questão. São esses temas nucleares que orientam a construção dos problemas, que é a outra tarefa do grupo de planejamento.

Um exemplo de árvore temática:

Figura 21. Árvore temática do Módulo de Concepção e Formação do Ser Humano do curriculo de medicina da UEL em 1998.

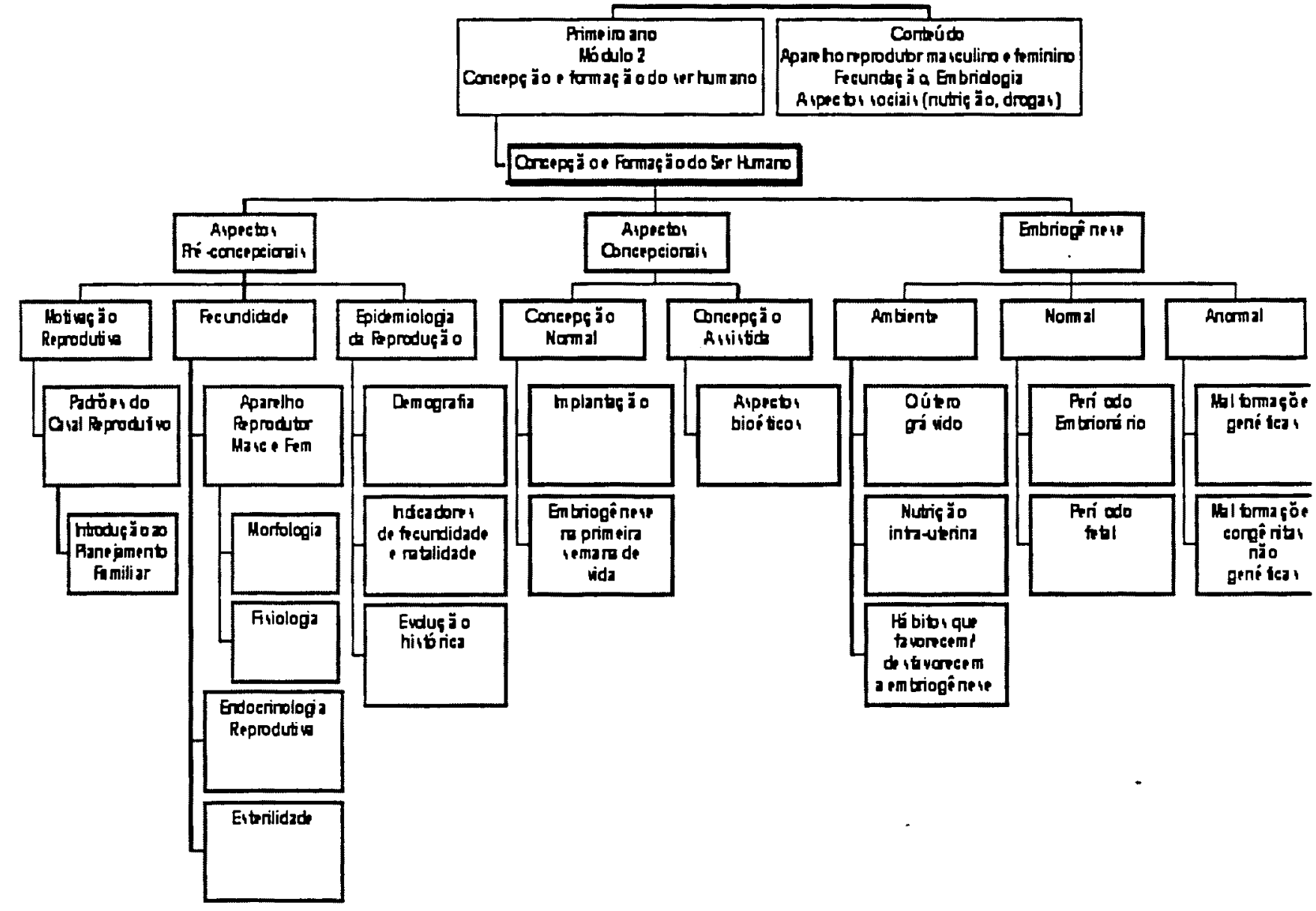

Fonte: Manual do Módulo 2. (UNIVERSIDADE, 1998c).

Claro está que os módulos comportam niveis distintos de articulação interdisciplinar, de articulação básico-clínico e desenvolvimento dos aspectos biopsicossociais, a depender das características intrínsecas dos temas e também dos conteúdos eleitos. Por exemplo, tomando dois módulos da $1^{\text {a }}$. série: o 
planejamento de Metabolismo envolveu a participação de 6 professores do CCB, 1 do CCE, 1 do MISC e 1 da CM, enquanto que o de Envelhecimento envolveu 4 docentes do $\mathrm{CCB}, 2$ do $\mathrm{CCH}, 5$ da CM, 2 da CC, 1 do MISC e 1 do Setor de Nutrição do HU.

Segundo o Entrevistado L2, também é variável o grau de "democracia" na construção dos módulos: uns têm sido mais participativos, outros nem tanto - e essa característica tem sido definida basicamente pelo perfil dos respectivos coordenador e vice-coordenador. Apesar disso, não têm existido mecanismos institucionais de controle acerca da dinâmica e tampouco acerca do produto do trabalho dessas equipes.

Conforme se foi avançando no curso, especialmente no $4^{\circ}$. ano, houve maior dificuldade em garantir a articulação entre disciplinas básicas e clínicas, como se pode constatar pela decrescente participação dos professores das outras áreas que não as clínicas no processo de planejamento dos módulos. Esse problema foi identificado no grupo focal dos docentes (L) e também nos fóruns de avaliação dessa série.

Analisando os objetivos educacionais planejados para os módulos, verificase que praticamente todos estabelecem objetivos na área biológica (básicos $\mathrm{e}$ clínicos), na área social e na área psi. No entanto, analisando os problemas de cada um dos módulos, chega-se ao seguinte perfil:

- no primeiro ano, de 60 problemas analisados, havia 45 com objetivos no campo da área básica, 42 no campo clínico, 29 no campo social e 3 na área psi. Ou seja, a maior parte dos problemas envolvia objetivos que articulavam as várias áreas do saber. 13 problemas combinavam objetivos nas 3 áreas (básico, clínico e social); 35 combinavam objetivos em duas áreas (e a combinação mais freqüente era básico-clínica) e 10 problemas tinham objetivos em uma só área (e a mais freqüente foi a social). 
- no segundo ano, de 57 problemas analisados, havia 35 com objetivos na área básica, 48 na área clínica, 28 na área social e 24 na área psi.Um problema combinava objetivos na 4 áreas; 30 combinavam objetivos em 3 áreas (básico-clínico-psi 12, clínico-social-psi 9 e básico-clínico-social 9); 16 problemas em 2 áreas (básico-clínico 5 , clínico-social 6) e havia 11 problemas com objetivos em uma só área (básico 6 e clínico 5)

- no terceiro ano, de 58 problemas analisados, havia 12 com objetivos na área básica, 53 na área clínica, 6 na área social e 14 na área psi. Desta vez, a maioria, ou seja, 31 problemas tinha objetivos em uma só área predominou a área clínica. Mas havia 23 problemas com objetivos em 2 áreas - desses, 8 eram básico-clínico e 11 eram clínico-psi - e 4 problemas tinham objetivos básico-clínico-sociais.

- no quarto ano, de 58 problemas analisados, havia 8 objetivos na área básica, 55 na área clínica, 8 na social e 4 na área psi. Outra vez predominaram problemas com objetivos somente em uma área - a clínica - em 40 casos. Apenas 16 problemas combinavam objetivos em 2 áreas (6 clínico-sociais, 3 clínico-psi e 7 básico-clínicos) e havia somente 2 problemas combinando os objetivos de 3 áreas.

Assim, de um equilíbrio muito bom em termos de articulação básico-clínica e de dimensões biopsicossociais nas duas primeiras séries, passamos a uma situação menos positiva na terceira e para uma situação de baixa integração na $4^{\mathrm{a}}$ série.

Talvez a própria temática dos módulos, que se articulavam em torno dos ciclos de vida e do eixo ecológico nas duas primeiras séries, tenha facilitado a integração elementos básicos, clínicos, sociais e psicológicos à abordagem dos temas nos módulos das duas primeiras séries. $\mathrm{Na} 3^{\mathrm{a}}$ e $4^{\mathrm{a}}$ série, os módulos se organizaram principalmente em torno de agrupamentos de sintomas ou topologia e isso pode dificultar a integração. 
Foi possível, também, nas primeiras séries, introduzir novas temáticas como as relacionadas ao meio ambiente, à saúde no trabalho - e novas abordagens, incluindo a bioética, os direitos cidadãos etc. Os problemas em geral trazem uma visão mais contextualizada, trabalham com elementos significativos da realidade. O que não acontece na $4^{\text {a }}$ série, quando os problemas deixaram de ser problemas e passaram a ser casos clínicos, em que se apresentam de saída todos os dados clínicos e laboratoriais. Segundo BARROWS (1986), um problema não deve conter todas as informações necessárias para sua solução, permitindo e estimulando que o estudante busque e articule outros dados. É essa característica que torna os problemas diferentes de um estudo de caso clínico.

Todos esses são, na verdade, indicativos de que a construção da integração das dimensões e de uma abordagem mais integral e contextualizada do processo saúde-doença não acontecem espontaneamente: têm que ser perseguidos ativamente. Portanto, seria indispensável que houvesse uma permanente ação problematizadora e o aporte de outros recursos para novas abordagens.

No entanto, em função da disputa de espaços de poder e da falta de estratégias adequadas, isso não ocorreu de maneira satisfatória. De modo que: "continua, em toda reunião, a gritaria de que nosso curso de social não teria nada... As pessoas não sabem como fazer isso e não é fácil de resolver. Por exemplo, na área da bioética,colocamos o Zé Eduardo 5 para fazer uma revisão de todos os módulos para ele ver onde pode encaixar uma questão, introduzir um tema, propor uma consultoria. Mas é um esquema muito artificial: tinha é que estar incorporado na cabeça e na prática dos professores" (Entrevistado L2).

A partir do $3^{\circ}$ ano, além dos problemas, efetivamente também são incluídos nos módulos alguns casos clínicos. Inicialmente estes sim, são casos montados para estimular o raciocínio clínico e a busca de informações pelos estudantes. Mas essa 
qualidade tampouco se mantém ao longo do $4^{\circ}$ ano. Aparentemente a Comissão de Habilidades acumulou mais em relação ao estímulo à construção do raciocínio clínico, mas esse saber não está escrito nem está sendo compartilhado com os demais docentes da área clínica.

Apesar de haver uma tendência na área clínica de os docentes preferirem participar nos módulos cuja temática é parte de sua área de especialização (76\% dos respondentes na pesquisa de AGUIAR (2001) fizeram essa afirmação), docentes e estudantes concordaram ser perfeitamente possível - e muitas vezes mais satisfatório - um professor do básico conduzir um módulo em que há muitos conteúdos clínicos. Isso porque os objetivos pedagógicos estão estabelecidos e o papel do tutor é de estimular a discussão.

Os professores destacaram o fato de que participar de módulos distintos do de sua área de concentração original tem servido para "estudar tudo outra vez", oportunidade muito valorizada por um contingente significativo de docentes:

" eu vou caminhar junto com o corpo, quem sabe depois de 4 anos eles me dão o diploma...ai só falta o internato" (Grupo focal dos docentes L).

"ela estuda tudo do módulo para poder acompanhar..." (Grupo focal dos docentes $L$ ).

"eu, por exemplo, tenho muita vontade de fazer alguns módulos..." (Grupo focal dos docentes $\mathrm{L}$ ).

"essa abordagem transdisciplinar é muito interessante. Antes a gente ficava cada um no seu castelinho, cada vez mais alheio aos outros conteúdos e práticas. E agora se renovam o interesse e a possibilidade de diálogos" (Grupo focal dos docentes L).

Na avaliação da primeira versão do módulo de Nascimento, Crescimento e Desenvolvimento, oferecido na segunda série, "o grupo do Prof. $X$ (sociólogo) se

\footnotetext{
${ }_{5}^{5}$ Prof. José Eduardo Siqueira, doutor em cardiologia e mestre em Bioética, professor do Departamento de Clínica Médica do CCS da UEL, autor do livro "Etica e tecnociência -uma abordagem segundo o princípio da responsabilidade de Hans Jonas", publicado pela Editora da UEL em 1998.
} 
sobressaiu em relação aos outros, pois o número de informaçōes trazidas foi de 30 a $40 \%$ maior que o dos outros grupos" (COMISSÃO, 1999b). Essa é uma polêmica presente em todas as escolas que adotaram a metodologia da aprendizagem baseada em problemas, sem solução na literatura.

Também houve dificuldades em relação ao comportamento dos tutores. Os da área clínica, em sua maioria, tinham menos experiência e menor grau de reflexão crítica sobre a prática pedagógica que os das básicas e, portanto, tiveram maiores dificuldades para cumprir o papel de tutor. Além disso, também apresentavam tendência a supervalorizar os aspectos clínicos. Problemas esses também identificados por professores e estudantes (Grupo focal dos docentes L e Grupo focal dos estudantes L).

$\mathrm{Na}$ verdade, a preocupação com a adesão dos clínicos era tão grande, que não foram feitas quaisquer tentativas de correção de curso durante a implantação dos módulos especialmente do $4^{\mathrm{o}}$ ano - apesar de as tendências de crescimento da biologização e diminuição da integração haverem sido percebidas. "Melhor implantar os módulos com defeitos que não implantar" (Entrevistado L2).

\subsubsection{Os cenários de aprendizagem e o conteúdo das práticas}

\subsubsection{Os PINs}

Como já foi apresentado, houve um momento inicial de conflito para garantir a existência das práticas integradas com os serviços e a comunidade. Apesar de haver a decisão do Colegiado defendendo a existência e a obrigatoriedade desses módulos, o trabalho para sua implantação ficou a cargo de um grupo muito pequeno de docentes.

Isso acarretava problemas, especialmente para pensar e concretizar o PIN para as outras séries que não a primeira, pois apesar de ser proposto como módulo multiprofissional, concretamente em 1999 (o PIN2), em 2000 (o PIN2 e o PIN3) e em 2001(o PIN3 e o PIN4) o PIN foi um módulo só para estudantes de medicina (a 
enfermagem só começou a participar das atividades do segundo ano a partir de 2000).

Inicialmente, no PIN1, continuou sendo preservada a mesma proposta original, desenhada como PEEPIN, envolvendo estudantes dos cinco cursos da área da saúde. Os estudantes são divididos aleatoriamente em Grupos Interdisciplinares e Multiprofissionais (GIM), com aproximadamente 15 alunos. Cada GIM desenvolve suas atividades na área de abrangência das Unidades Básicas de Saúde localizadas na área urbana de Londrina.

Primeiro se faz um "passeio ecológico" para identificar quais são os problemas mais freqüentes, como a comunidade se organiza para resolvê-los, como eles são ou não resolvidos. Depois é escolhido um problema para ser estudado e os alunos partem do material que já foi produzido por grupos anteriores (OFICINA, 1998).

No processo, os estudantes chegam a elaborar e colocar em prática uma proposta de intervenção (exemplos: organização do conselho de saúde onde não há, montagem de um grupo de hipertensos, identificação de focos de dengue e trabalho para erradicá-los etc.). Muitas dessas ações são desenvolvidas em conjunto com os outros atores do cenário local.

Há problemas (já clássicos, considerando o tempo de existência do PEEPIN) que haviam sido identificados (OFICINA, 1998):

- desconhecimento dos objetivos do PIN pelos alunos;

- os estudantes acham chata a parte da teorização (apesar de o balanço final ser positivo - “depois você vai entender que isso é importante”);

- expectativa do aluno em relação ao que é a prática não corresponde ao que encontram no módulo;

- os instrutores consideram que esse trabalho exige muito tempo, muita dedicação;

- desconforto inerente à percepção da complexidade dos problemas, à lentidão da mudança, à impotência diante das situações 
- dificuldades em conseguir instrutores, principalmente das outras carreiras;

- dificuldades em desenvolver as atividades fora do horário do PIN (à noite, etc)

Surgiram, além disso, problemas pelo fato de essa atividade ser obrigatória somente para os estudantes de medicina (e para os de enfermagem a partir do ano 1999), que diziam respeito principalmente a diferenças na seriedade com que eram encaradas as tarefas e no compromisso que se conseguia construir dentro do grupo.

Como agora as atividades não se restringem mais ao primeiro ano, surgiu também, por parte dos estudantes, uma demanda antiga da comunidade: a continuidade das atividades realizadas de um ano para o outro (grupo focal de docentes L) (grupo focal de outras carreiras, profissionais dos serviços e representantes da comunidade $\mathrm{L}$ ).

Havia, no entanto uma resistência importante em implementar mudanças no PEEPIN, quase como se ele fosse uma peça clássica, uma referência histórica, que, por sua importância no processo inicial de construir as transformações, não pudesse ser "mexido". Somente em 2001 é que foi possível pensar uma proposta global para os 4 anos de PIN.

Antes de construir a proposta para a primeira edição do PIN2, houve em Londrina uma oficina de trabalho, em conjunto com Marília, para discutir PIN/Interação Comunitária.

Nessa oficina ficou claro que o PIN é um espaço privilegiado do fazer e da prática, mas que não poderia ficar isolado das outras atividades do currículo, ou seja, ele teria que acontecer de maneira integrada ao desenvolvimento dos módulos. Identificava-se que o PIN poderia ser um espaço privilegiado para a aquisição de habilidades não só no terreno da saúde coletiva, mas no terreno do cuidar, do estabelecimento de relações (OFICINA, 1998). 
Considerou-se também que o PIN poderia se converter num espaço privilegiado de construção de novas práticas com a participação efetiva de todos os sujeitos envolvidos. E que haveria cenários favoráveis para isso: o Programa de Saúde da Família e a Internação Domiciliar seriam apenas dois exemplos imediatos.

Identificou-se também a necessidade de diversificar os atores da academia envolvidos nesse trabalho. Os docentes e as disciplinas clínicas deveriam ser chamados a contribuir nesse espaço. Seria uma oportunidade interessante de mostrar que clínica não é só diagnosticar, prognosticar e curar os problemas como "disfunção biológica"; pode ser também o espaço de produção de relações e intervenções, que se dá de modo partilhado e no qual há um jogo entre necessidades e modos tecnológicos de agir. Assim seria possível abrir espaço para discutir uma outra questão: o cuidar. O objeto do PIN seria "o cuidado em saúde", desenvolvido em todas as suas dimensões (OFICINA, 1998).

A situação política na relação com os serviços de saúde no período de 1997 a 2000, como mencionado, não facilitou o avanço dessas idéias. A Saúde da Família, por exemplo, deixou de ser um projeto prioritário para a secretaria municipal de saúde e houve redução do número de equipes. Havia resistência do secretário até mesmo em abrir o espaço das unidades básicas para o trabalho dos estudantes.

Tampouco dentro da academia a situação foi muito favorável: como ampliar o espectro dos professores envolvidos? Uma convocação feita somente a partir dos PINs teria dificuldade de aceitação: seria necessário desenvolver outras estratégias ou contar com uma ação firme da direção do curso nesse trabalho. Nenhuma das duas coisas aconteceu, no entanto.

O PIN2 foi estruturado com duas possibilidades de inserção para os estudantes: a inserção nas unidades básicas de saúde ou a conformação de grupos de investigação acerca de agravos prevalecentes na atenção básica. Foi feito um treinamento rápido em epidemiologia clínica e leitura crítica de artigos científicos 
nas primeiras cinco semanas do ano letivo e então aberta a possibilidade de eleição das atividades pelos estudantes.

Assim, durante o ano de 1999, sete grupos de 4 a 5 alunos trabalharam em diferentes Unidades Básicas de Saúde, observando e colaborando com os programas de atenção à saúde da criança, da mulher e do adulto/ idoso lá desenvolvidos, e cinco grupos de 9 a 10 alunos estudaram cinco agravos sugeridos pela Secretaria Municipal de Saúde: Infecções Respiratórias Agudas, Diarréias, Hipertensão Arterial, Hepatites e Lombalgias (TURINI et al, 1999b).

O grupo de instrutores do PIN 2 considerou que as atividades desenvolvidas em 1999 possibilitaram aos alunos "uma visão da organização da sociedade e dos serviços de saúde frente os principais agravos, a iniciação na metodologia cientifica e o desenvolvimento de espirito crítico em relação aos problemas sociais e às politicas da saúde" (TURINI et al., 1999b). Mas os alunos consideraram que essa modalidade de inserção não "configurava" um PIN, pois não possibilitava a participação efetiva no cenário real (grupo focal de estudantes L).

Para o PIN3 a proposta foi a participação dos estudantes no trabalho das equipes de saúde da família, considerando que pudessem participar ativamente das atividades de promoção e prevenção dentro e fora das unidades. No entanto, para que isso fosse possível, foi necessário estabelecer convênios com as prefeituras vizinhas e "espalhar" os alunos por muitos lugares diferentes, já que não havia número suficiente de equipes em Londrina. Essa dispersão comprometeu as possibilidades de um seguimento adequado dos grupos de estudantes e de uma articulação mais profunda com os outros parceiros.

Para a primeira versão do PIN4 a proposta foi a inserção nas equipes, mas agora para participar das ações de atenção médica, tanto no espaço domiciliar como nas unidades. Somente um docente ficou encarregado de supervisionar o trabalho dos estudantes e houve muitos problemas para a integração com os médicos das unidades, especialmente das UBS. 
As relações difíceis com a secretaria municipal de saúde de 97 a 2000 explicam em parte essa necessidade de improvisação. Mas a verdade, é que teria sido possível avançar mais no trabalho diretamente com os profissionais médicos das unidades, assim como se fez na enfermagem. Não houve conjuntura política desfavorável que impedisse o internato de enfermagem e a parceria ativa entre docentes e enfermeiras das unidades de funcionar, como apontam os profissionais dos serviços: "diferentemente do que aconteceu na enfermagem, não houve um trabalho prévio com os médicos da rede e até gente legal se recusou a participar (do PIN 3) por conta disso" (Grupo focal dos profissionais dos serviços, professores de outras carreiras e da comunidade L).

Isso revela, uma vez mais, a existência de uma dificuldade, que vai além da política, em abordar o trabalho dos clínicos de maneira inovadora. Apesar de haver, em vários momentos, a sugestão de estratégias que poderiam ser úteis (FEUERWERKER, 2000); (REDE UNIDA, 2001c), aparentemente os atores mais ativos do processo ficam paralisados diante desse desafio.

Por conta dessa falta de estratégias, não se pôde superar alguns problemas importantes como a falta de instrutores para os PINs, tanto na academia como nos serviços, a falta de integração entre os conteúdos abordados nos módulos e no programa de habilidades etc.

Apesar disso, o PIN não é alvo preferencial das críticas dos estudantes - a avaliação e as habilidades é que o são (FORUM, 2000). Afora a reclamação quanto à falta de supervisão adequada, os estudantes dizem que "os PINs são um jeito de saírem bastante, de conhecerem o mundo real" (Grupo focal dos estudantes L).

Os observadores externos (comunidade, serviços, professores das outras carreiras) têm o PIN como a única "janela" através da qual conhecem ou têm participação no novo currículo. Gostam muito. Mas acham que poderiam participar mais.

Diferentemente do que acontece no PEEPIN e no internato de enfermagem, até o ano 2000, não houve qualquer participação dos serviços e da comunidade na 
definição do trabalho dos PINs, apesar de ambos acharem "que seria muito mais interessante e produtivo se fosse diferente". (Grupo focal dos profissionais dos serviços, professores de outras carreiras e da comunidade $L$ ).

A entrada da enfermagem e a nova mudança de orientação política na secretaria da saúde configuraram um cenário mais favorável para os PINs a partir de 2001. Atualmente está havendo um processo de reconstrução dos PINs, feito de maneira conjunta entre os dois cursos e os profissionais dos serviços de saúde.

Primeiramente um grupo de docentes da medicina e da enfermagem iniciou a discussão; considerou-se que o contexto atual de implantação generalizada da Saúde da Família em Londrina abria uma possibilidade imperdível de se aproximarem das idéias perseguidas há tantos anos.

Depois, foram constituídas equipes mistas, com a participação dos profissionais dos serviços, para a construção dos objetivos e das propostas de trabalho do PIN para cada série. No entanto, ainda faltaria incorporar a comunidade...

Numa definição bem curta, o conteúdo da proposta atual é: "integrar os estudantes às equipes de Saúde da Familia, sendo que seu trabalho seria: no primeiro ano na comunidade e até o portão das casas; no segundo ano do portão até à sala e à cozinha das casas; no terceiro ano da sala até o quarto dos acamados e doentes da casa e quarto ano nos ambulatórios das Unidades de Saúde da Familia..." (UNIVERSIDADE, 2002c).

Ou seja, no primeiro ano seria trabalhado o território e o diagnóstico de problemas e recursos de saúde, basicamente através da territorialização, do diagnóstico dos problemas ambientais, dos mapas vivos, dos mapas de risco e do trabalho em equipamentos como escolas, creches, entidades comunitárias etc.

No segundo ano, começaria a abordagem familiar tanto nas unidades de saúde como nas casas, participando das ações de promoção e prevenção. No terceiro ano já se avançaria para o desenvolvimento de habilidades clínicas, do trabalho em equipe, acolhimento, responsabilização, anamnese ampliada e redação científica, fundamentalmente através da atenção aos pacientes atendidos em casa. 
No quarto ano, o estudante participaria de todos os tipos de atividades desenvolvidas em relação ao tema hipertensão - atendimento clínico, grupos, complicações, promoção à saúde etc. Como mencionado, essa proposta ainda está em elaboração.

\subsubsection{As práticas para o desenvolvimento de habilidades}

Inicialmente as habilidades eram uma atividade voluntária. A idéia era que os estudantes buscassem as atividades de acordo com suas necessidades específicas de treinamento e capacitação. Esse esquema vigorou apenas no $1^{\circ}$. ano da implantação, diante da baixa adesão dos estudantes, que não conseguiam identificar a importância dessa área - descolada que estava das outras.

A partir do segundo ano, as habilidades se tornaram obrigatórias, num período semanal de quatro horas. O programa compreende habilidades em acesso à informação médica e de exame físico ( $50 \%$ da carga horária), habilidades de comunicação social $(25 \%)$, de procedimentos médicos $(10 \%)$ e de realização de exames complementares (15\%) (UNIVERSIDADE, 1998a).

O trabalho com as habilidades está sob a coordenação de uma Comissão Geral e de três subcomissões. A comissão geral é composta pelo coordenador do Laboratório de Habilidades (que é da Clínica Médica), pela coordenadora geral das Habilidades (Pediatria) e pela vice-coordenadora das Habilidades (Saúde Coletiva) - além de um representante de cada subcomissão: de comunicação (psiquiatra do departamento de clínica médica), de semiologia (representante da antiga disciplina de semiologia da clínica médica) e de procedimentos (representante do PALD).

Cada uma das subcomissões trabalha de maneira diferente. Na comunicação, é que se discutem a relação médico-paciente, situações complexas como a relação com pacientes graves e terminais, a abordagem da família e alguns outros temas éticos. Seu planejamento é realizado por um grupo diferente para cada ano do curso, sendo que a coordenadora (psiquiatra) divide sua coordenação com uma psicóloga. No planejamento do trabalho com o $4^{\circ}$ ano, por exemplo, 
contribuem uma assistente social do Hospital Universitário, (que tem experiência com os pacientes HIV positivos) e uma enfermeira, do Depto. de Enfermagem, que tem experiência no cuidado com pacientes terminais da oncologia.

As habilidades de comunicação são desenvolvidas também no Laboratório de Habilidades, bem como e nos ambulatórios e enfermarias. As habilidades de busca de informação e de leitura crítica são desenvolvidas na Biblioteca, no Laboratório de Informática e em salas para trabalho e discussão em grupo.

O trabalho da subcomissão de semiologia é planejado principalmente pelos professores da antiga disciplina de semiologia, do Depto de Clínica Médica, com algumas contribuições de disciplinas específicas - oftalmologia, otorrinolaringologia, dermatologia, cirurgia vascular - na programação das atividades dos últimos anos. As atividades são desenvolvidas inicialmente no Laboratório de Habilidades (através de simulação e exercício inter-pares) e posteriormente nos ambulatórios do Hospital das Clínicas e enfermarias do Hospital Universitário.

Os coordenadores oficiais da área de procedimentos clínicos são um professor de hematologia do laboratório de análises clínicas e uma professora da microbiologia do CCB. Eles trabalham com o apoio do coordenador do Laboratório de Habilidades e da coordenadora geral de Habilidades, que é quem efetivamente articula e organiza todas essas atividades ao longo dos quatro anos, que são múltiplas e variadas. Envolvem desde professores do departamento de microbiologia do CCB, até o pessoal da UTI e da técnica cirúrgica, passando pelos departamentos de enfermagem, de patologia aplicada, e as disciplinas de radiologia, ortopedia, entre outros.

As habilidades em procedimentos clínicos são desenvolvidas no Laboratório de Habilidades, nos laboratórios específicos que forem apropriados e também nas enfermarias e ambulatórios.

No ano 2000, as habilidades em semiologia foram alvo de intensas críticas e questionamento por parte dos estudantes, especialmente pela baixa qualificação 
dos instrutores e pela descontextualização da aprendizagem e treinamento das habilidades de semiologia. Os estudantes consideraram que se a aprendizagem das habilidades não estiver inserida num processo real de aproximação e interação com o paciente, o potencial de aproveitamento fica muito reduzido (FORUM, 2000).

Um outro aspecto considerado crítico pelos estudantes foi a ausência de uma definição clara - conhecida pelos estudantes - a respeito de quais são as habilidades que a formação geral do médico implicaria desenvolver. Solicitaram a elaboração de uma manual geral, que possibilitasse a identificação da progressão dos conteúdos ano a ano, com referências bibliográficas e roteiros de atividades (FORUM, 2000).

\subsubsection{As práticas dos módulos}

São atividades propostas pela equipe organizadora do módulo, consideradas essenciais para a abordagem do tema em questão. Podem ser atividades em laboratórios básicos (anatomia, microbiologia, fisiologia, farmacologia), no laboratório morfo-funcional, práticas integradas das várias disciplinas básicas em laboratórios, laboratório clínico, práticas ambulatoriais pediatria, obstetrícia, geriatria, oftalmologia - visitas ao Sistema Integrado de Atenção ao Trauma e Emergências (SIATE), ao CCI, à Maternidade Municipal, a instituições asilares, a órgãos de informação em saúde, ao serviço de fisioterapia e ao serviço social do Hospital Universitário, práticas nas enfermarias do Hospital Universitário, reuniões anátomo-clínicas etc.

As mais freqüentes - presentes em todos os módulos - são as práticas em laboratórios básicos e nos ambulatórios do Hospital Universitário. 


\subsubsection{As eletivas}

O módulo de eletivas é desenvolvido anualmente, geralmente durante 4 semanas. Inicialmente, como comentado, os estudantes podiam optar entre uma lista de atividades oferecidas pelos docentes - laboratoriais, de investigação, prática clínica etc.

Assim foi nos dois primeiros anos de implantação, mas já no terceiro ano deixou de haver um "cardápio restrito", de modo que os estudantes puderam apresentar propostas e desenvolver as atividades eletivas em qualquer cenário, inclusive fora de Londrina, desde que a proposta fosse aprovada pelo Colegiado. Houve de tudo: acompanhamento de profissionais médicos da cidade em todas as suas atividades, adesão ao estágio de UBS realizado pela Universidade Federal de São Paulo, estágios em laboratórios, estágios dentro do HU sob supervisão docente etc.

No quarto ano ainda não se chegou a realizar as eletivas por conta da greve, mas havia uma expectativa de que os estudantes optassem por cenários como o SIATE, a Maternidade Municipal etc., já que há uma resolução do Colegiado determinando que as práticas eletivas não sejam realizadas no Hospital Universitário, numa tentativa de reforçar a efetiva diversificação dos cenários.

Não existe informação sistematizada sobre as eletivas que possa ser utilizada para uma análise mais cuidadosa, tais como a lista das possibilidades, distribuição dos estudantes, análise dos relatórios produzidos pelos estudantes ao final do período etc.

\subsubsection{O Internato}

À época da aprovação da mudança, para garantir a aprovação do currículo novo, fez-se um compromisso em torno da manutenção da estrutura e do conteúdo do internato. 
Apesar de os estudantes trabalharem em pequenos grupos e de a aprendizagem se dar em torno da prática, desde a mudança curricular resultante da passagem do regime de créditos para o regime seriado (em 1992), o internato havia ficado totalmente hospitalar e muito fragmentado, havendo estágios em várias subespecialidades clínicas e cirúrgicas.

“...esse novo internato que saiu, que desde o início desse que está ai agora, a gente teve críticas violentas a ele, né, a gente achava que o outro internato era muito melhor ...". [...] "... nesse internato que está ai agora, e eu acho o que é 0 grande pecado dele, é que disciplinas, que já tinham sido votadas, até nos fóruns do internato, como não sendo necessárias, tipo cirurgia plástica, tipo anestesia, etc., que [...] no outro internato elas eram ofertadas como opcionais; o aluno [...] escolhia. Só que, agora, a partir de agora, esse internato passa a oferecer como disciplina obrigatória" (entrevista com docente D in TURINI,2000).

"...em relação ao internato médico, que foi posteriormente discutido, ai sim, realmente o que houve, foi uma modificação para pior. O internato literalmente andou para trás, em função da institucionalização de alguns estágios opcionais, de especialidades que não existiam, e que foram instituídos como estágios obrigatórios. Na verdade essa foi a questão que completou a deformação curricular" (entrevista com docente A in TURINI, 2000).

Sabia-se, portanto, que esse internato tinha problemas, mas havia a expectativa de que ao longo de 4 anos haveria tempo suficiente para acumular força e massa crítica favoráveis a mais essa mudança. Não foi o que aconteceu. Neste ano de 2002 a primeira turma do novo currículo iniciará as atividades sem que se tenha conseguido introduzir nenhuma alteração sequer na sua conformação, dinâmica e conteúdos.

O internato se converteu no "bastião" dos opositores à mudança, concentrados principalmente na Clínica Cirúrgica. Nos últimos dois anos eles controlaram a preceptoria do internato, geraram alguns conflitos com o Colegiado de medicina (a quem estão subordinados) e recusaram qualquer alteração por 
múnima que fosse. Nem mesmo estágios no SIATE e na Internação Domiciliar, serviços de qualidade reconhecida por todos, foi possível incluir na estrutura atual.

Mas existem alguns elementos interessantes dentro e fora do hospital que podem favorecer mudanças. Na Clínica Médica, por exemplo, já há embriões de reflexão crítica sobre a prática clínica exercida no hospital. No grupo focal dos professores, reconheceu-se explicitamente "que a prática dominante no hospital não inclui história e exame fisico adequados, já que tudo isso foi substituido pelos exames complementares" e que essa situação era grave entre os internos e entre os residentes.

Foi constituído um grupo-tarefa, interdisciplinar, sob a direção do coordenador do colegiado de medicina, para trabalhar na elaboração da proposta de Londrina para candidatar-se ao Programa de Incentivos às Mudanças nos Cursos de Medicina ${ }^{6}$ lançado em dezembro pelo Ministério da Saúde e pelo MEC.

No diagnóstico desse Grupo sobre a situação atual do curso de medicina da UEL, diz-se que "o internato é hospitalocêntrico (hospital terciário). A especialização precoce, sem visão do atendimento mais básico, contraditoriamente, se acentuou com o desenvolvimento da rede de atendimento primário e secundário da cidade, pois os alunos têm pouco acesso a casos simples (ex: tuberculose, pneumonia)" (UNIVERSIDADE, 2002b).

Nesse mesmo diagnóstico, identificou-se a existência de um movimento pela humanização da atenção no hospital, que envolve a participação dos usuários na avaliação da atenção prestada e que está sendo coordenado pelo professor de bioética (que é membro do grupo-tarefa). Por enquanto esse trabalho teve maior impacto sobre a enfermagem, mas há "planos de expansão", o que certamente será uma boa oportunidade para problematizar práticas e cenários (UNIVERSIDADE, 2002b).

\footnotetext{
${ }^{6}$ Programa de Incentivos às Mudanças nos Cursos de Medicina (PROMED) - O programa pretende oferecer apoio técnico e financeiro para as escolas médicas que se dispuserem a entrar em processos de mudança que levem a um trabalho articulado com os serviços de saúde, à adoção de metodologias ativas de ensinoaprendizagem e à formação geral, crítica e humanista.
} 
A Secretaria Municipal da Saúde vem fazendo forte crítica à maneira como o Hospital Universitário e o Hospital das Clínicas estão inseridos no sistema de saúde. Basicamente há uma demanda no sentido de que sejam eliminadas as barreiras de acesso para que os serviços universitários realmente sirvam de retaguarda secundária e terciária (UNIVERSIDADE, 2002b).

Há também muitas expectativas em relação ao papel que os estudantes do novo currículo, com sua capacidade de crítica, de proposição e de pressão, vão cumprir dentro do processo de estimular as mudanças no internato (grupo focal dos docentes L).

Também há planos para a manutenção e a conquista de postos importantes dentro do hospital: a superintendência, a coordenação do internato, a chefia da preceptoria... (entrevistado L1).

Ou seja, já há planos, há aliados estratégicos e pistas sobre questões que podem servir como porta de entrada para a reorganização das práticas no hospital. Talvez esse seja o melhor caminho para chegar às necessárias mudanças no internato.

\subsubsection{A avaliação}

\subsubsection{A avaliação dos estudantes}

Esse tem sido um ponto polêmico no trabalho dentro do novo modelo, especialmente em relação à avaliação cognitiva.

Todas as possíveis técnicas propostas à época da aprovação do currículo efetivamente estão sendo utilizadas. No entanto, apesar de existir avaliação formativa e somativa, a postura geral - de docentes e de estudantes - frente à avaliação é bastante complicada; há de tudo um pouco - inseguranças, inexperiência, concepções contraditórias, inércia. 


\section{Avaliação formativa}

É realizada através da autoavaliação, da avaliação interpares e da avaliação do tutor em cada sessão tutorial e ao final de cada módulo. Gera muitas polêmicas: "Para que serve?" "Os docentes não querem se comprometer, então fica todo mundo no 4 ou 5 - só em casos extremos aparece um 1 ou 2" "Tenho dificuldades em praticá-la". (Grupo focal dos docentes L). "Os estudantes são corporativistas e não entendem o papel da avaliação formativa" (Entrevistado L4).

Em primeiro lugar, existem muitos docentes que não se consideram preparados para a avaliação formativa. Num levantamento feito no processo de repensar o processo de capacitação docente, somente $32 \%$ dos docentes se consideraram preparados para utilizar os instrumentos de avaliação dos alunos. Os demais 68\% ficaram "neutros" (38\%) ou disseram que não estão preparados (30\%) (AGUIAR, 2001).

"Essa modalidade de avaliação serviria somente para ajudar a mudar determinadas caracteristicas comportamentais dos estudantes?" - pergunta uma docente (Grupo focal dos docentes L). Outra diz que "muitos não percebem que ela seria um instrumento fundamental para acompanhar o processo de aprendizagem de cada aluno $e$ o próprio processo de ensino - aprendizagem". Outros percebem a importância e acham que é uma questão de tempo para haver uma adaptação de todos (Grupo focal dos docentes L).

Os professores, entretanto, reconhecem também que houve progressos, que atualmente todos se preocupam com o tema da avaliação, que antes costumava ser "evadido": "no velho esquema, os professores fingiam que ensinavam e que não viam os problemas, os estudantes fingiam que aprendiam e todos ficavam felizes com a média 5 . Ninguém se responsabilizava por nada". (Grupo focal dos docentes L)

Reconhecem também que os problemas, ou melhor, os "alunos-problema" (um caso de esquizofrenia, por exemplo) são identificados mais rapidamente e acompanhados com maior cuidado. Estão de acordo também que "o mais importante na avaliação formativa não é a "nota", mas a discussão a respeito de sua justificativa" (Grupo focal dos docentes L). 
Um segundo problema é conceitual. Diz respeito ao fato de o resultado da avaliação formativa ser utilizado para compor a nota final dos estudantes, o que acaba, na prática convertendo-a em uma outra modalidade de avaliação somativa. Esse problema já havia sido identificado previamente em fóruns de avaliação e por consultores externos:

"Make a clear distinction between program and student evaluation. Make a clear distinction between formative and summative assessment tools. You may use results of summative assessment for formative purposes, but do not use later the formative assessment for summative purposes" (SNELLEN-BALENDONG \& GOEIJ, 1999).

Apesar de identificados há bastante tempo, também esses problemas na avaliação não foram resolvidos e foram se agravando. No ano 2000, como mencionado, o Fórum de Debates dos estudantes foi organizado para discutir mais profundamente os (por eles considerados) dois problemas mais importantes do curso: a avaliação e as habilidades em semiologia. Em relação à avaliação formativa, destacaram que:

- "a avaliação formativa é ótima, contribui para melhorar o aluno/grupo/tutor"

- “incentiva o aluno em seus estudos constantes e não só na véspera da prova"

- "serve para corrigir falhas durante o processo e exige muita maturidade"

- "tira o caráter punitivo da avaliação"

- "os tutores deveriam ser melhor preparados para realizá-la"

- "deveria ser anônima"

- "não deveria valer nota"

- "serve para compensar as baixas notas da prova somativa" (FORUM, 2000).

No grupo focal dos estudantes esse tema apareceu também com grande importância. Foi dito que: 
"Os estudantes entendem a importância da avaliação formativa. Valorizamna, sendo sinceros na avaliação oral. Mas o que dizem não tem nada a ver com a nota que escrevem no papel, porque estão usando a avaliação interpares e a autoavaliação para se protegerem dos maus resultados na avaliação cognitiva" (Grupo focal dos estudantes L).

Todos os entrevistados também mencionaram a questão da avaliação como um problema importante e não adequadamente resolvido. O Entrevistado L4 considera que as dificuldades são parte do processo e vão ser superadas. Já o Entrevistado L2 diz que uma das razões para essas dificuldades na avaliação são as normas da universidade, que continuam exigindo uma nota e uma qualificação em relação à aprovação do aluno ao final do módulo:

"uma explicação para esses problemas é o fato de não havermos conseguido mudar as normas da universidade, que exigem nota - e o CCS não tem força para tanto - e nem havermos encontrado uma maneira de compatibilizar o espírito da nova proposta de avaliação com esse sistema arcaico - isso seria possivel fazer junto com a CAE, mas nem se tentou". (Entrevistado L2)

Outras normas da universidade foram mudadas para viabilizar a implantação das mudanças nos cursos de medicina e de enfermagem. Quais as razões, então, para não haverem tentado mudar essas normas? Provável falta de clareza conceitual, divergências conceituais em torno do tema dentro do próprio CCS, falta de debate mais sistemático sobre o assunto foram algumas das explicações aventadas pelos entrevistados e pelos docentes (Entrevistados L2, L4 e L5); (Grupo focal dos docentes L).

\section{Avaliação somativa}

Também neste caso todas as modalidades imaginadas estão sendo utilizadas e também aqui há muitas polêmicas e discussões.

Em relação à avaliação cognitiva, o Fórum de Debates propôs que: 
- "Deve ser feita, em sua totalidade, na forma de casos clínico ou na forma de problemas;.

- Conteúdo cobrado deve abranger os objetivos propostos e atingidos pelos grupos tutoriais;

- Todas as questões devem ser interdisciplinares e contextualizadas na prática clínica. Devem ter relevância para a formação do médico generalista.

- O grupo de planejamento do Módulo deve ser o responsável pela elaboração da prova, sendo que este também deverá verificar se os objetivos atingidos estão sendo contemplados nas questões.

- A Comissão de Avaliação deve ser criteriosa na revisão da Avaliação Cognitiva, para que o conteúdo relevante seja cobrado e as "minúcias do conhecimento" descartadas.

- Feedback com a prova logo em seguida da realização da avaliação, feito pelo grupo de planejamento do Módulo.

- Emissão de relatórios individuais sobre os objetivos não alcançados pelo aluno com base nas questões erradas" (FORUM, 2000).

Em relação à OSCE, os estudantes propuseram que essa não fosse a única modalidade de avaliação das habilidades e que se desenvolvessem mecanismos formativos - como um instrumento que apontasse os erros e as soluções - para possibilitar o retreinamento de procedimentos deficitários. Para as avaliações práticas sugeriram também maior coerência entre os conteúdos cobrados e os objetivos atingidos pelos módulos, além de maior contextualização das situações na prática clínica (FORUM,2000).

\subsubsection{A avaliação do currículo}

Durante o primeiro ano, a Comissão de Avaliação realmente utilizou as informaçōes recolhidas através de várias fontes para uma avaliação sistemática dos problemas, dos módulos, produzindo pequenos relatórios analíticos, que eram 
discutidos entre todos - docentes, estudantes, coordenadores etc (COMISSÃO, 1998a); (COMISSÃO, 1998 b).

Logo ao início do segundo ano, no entanto, o sistema de processamento dos dados da avaliação entrou em colapso; os dados continuaram a ser colhidos, mas deixaram de ser processados e analisados. Esse problema da informática até hoje não foi resolvido.

Durante algum tempo a análise dos problemas continuou sendo feita, ainda que as informações tivessem que ser processadas manualmente, mas depois foi abandonada.

$\mathrm{Na}$ verdade, os coordenadores de cada módulo examinam o material da avaliação e compartilham as informações com os participantes daquela unidade especificamente. As reformulações de cada módulo e dos problemas (que ocorrem todos os anos) são feitas com base nessa análise informal e, principalmente, com base nas informações expressas oralmente nas sessões de avaliação (Entrevistado L5).

Além disso, ao final de cada módulo, o coordenador reúne todos os participantes para uma avaliação a respeito de todos os aspectos envolvidos, desde a infraestrutura, passando pela qualidade dos materiais utilizados - peças, impressos, manuais - pelos instrumentos de avaliação, os estágios e atividades práticas, as conferências, os problemas, os tutores. Avaliam-se os objetivos (pertinentes ou não; abrangentes ou não, precisos ou não), se foram atingidos e por que.

Apesar de muito úteis, essas sessões não possibilitam uma análise mais profunda de cada um dos aspectos mencionados. É possível que problemas importantes não sejam valorizados, pois muitas observações ficam no terreno das opiniões, sem evidências, sem documentação e podem ser tratadas como diferenças de ponto de vista e nada mais.

Anualmente, também têm sido realizados Seminários de Avaliação, que contam com importante participação de estudantes e professores. Nesses 
seminários todos os aspectos do currículo têm sido avaliados, os principais problemas são identificados e são propostas soluções. Nem sempre, no entanto, as propostas chegam a ser implementadas na prática.

\subsubsection{A gestão do processo de mudança}

Foi um processo complexo a construção da estratégia para aprovação da nova proposta. Apesar de haver uma importante e significativa massa crítica de docentes e estudantes não somente favoráveis à mudança, mas extremamente mobilizados para levá-la à prática, havia também um contingente importante de docentes indiferentes (especialmente na clínica médica) e outro significativo grupo que se opunha às mudanças (explicitamente na clínica cirúrgica).

A oposição era minoria, mas significativa. Não tinha poder suficiente para impedir a mudança, mas era suficiente para interferir no conteúdo da proposta. Essa situação exigiu, como mostrado, uma complexa engenharia política e a construção de alianças envolvendo a saúde coletiva, pediatras, clínicos e cirurgiões fundamentalmente.

\subsubsection{A Comissão de Implantação}

A Comissão de Implantação reunia figuras notáveis, que haviam cumprido um papel destacado na construção da proposta de mudança e em sua viabilização política e por isso mesmo haviam ocupado funções estratégicas no novo currículo. Tinha uma composição "enxuta", que deveria conferir-lhe agilidade, mas não tinha vínculos orgânicos com o corpo docente, pois, com exceção do coordenador e do vice-coordenador do colegiado, seus membros não haviam sido eleitos - haviam ocupado essas posições, em determinado momento do processo, por razões de mérito e de poder (alguns deles, juntamente com o diretor do CCS, hipoteticamente deveriam cumprir um papel fundamental na conquista da adesão dos clínicos). 
Criada pelo Colegiado, com poderes por ele delegados, a Comissão começou a funcionar como um poder paralelo, tomando decisões e contrapondo-se ao Colegiado em determinados momentos.

Apesar de muitas outras pessoas haverem sido capacitadas nas novas metodologias ativas e em outras áreas de "expertise", que eram necessários à implementação da nova proposta, vários membros da Comissão comportavam-se como se fossem os únicos detentores do "verdadeiro" saber sobre os elementos conceituais da mudança. Como eles ocupavam a coordenação das comissões de trabalho (Avaliação, Capacitação etc.), sua postura contribuiu para a impermeabilidade desses organismos às sugestões oriundas dos fóruns democráticos de avaliação, que sempre foram periodicamente realizados.

Durante o ano de 99, alguns membros da Comissão de Acompanhamento chegaram a contestar a competência técnica do colegiado para discutir assuntos relativos ao novo currículo. Sugeriram que eles deveriam, antes de opinar, ser melhor expostos à proposta e capacitados. No entanto, os membros do Colegiado já se haviam convertido há muito tempo em ativos participantes do processo. Levantamento, feito à época, mostra que dos 18 membros do colegiado, 10 já haviam participado do planejamento de módulos, 10 já haviam sido tutores, 9 já haviam sido consultores, 6 já haviam coordenado ou sub-coordenado módulos, 3 já tinham sido conferencistas e 1 tinha ficado encarregado das eletivas. Também haviam dado conta de construir e aprovar - no colegiado e no CEPE - todas as novas normas necessárias ao funcionamento do novo currículo (UNIVERSIDADE,1999a).

Diante dessa situação de disputa, os coordenadores do colegiado optaram, então, por uma política radical de transparência, ampliação e democratização de todas as discussões, fortalecendo a possibilidade de múltiplos atores assumirem protagonismo dentro do processo. Boletim do colegiado, publicação e divulgação das atas de todas as reuniões, criação de espaços coletivos de debate, agilidade no encaminhamento das questões práticas e políticas. 
O ápice do conflito entre Comissão de Implantação e Colegiado deu-se em uma polêmica em torno da possibilidade de professores não vinculados ao antigo currículo de medicina poderem ou não exercer o papel de tutores - a polêmica se originara pelo fato de esses docentes não serem da área da saúde e principalmente por não serem médicos. A Comissão num primeiro momento vetou essa participação, o Colegiado decidiu o contrário. Numa nova reunião, muito tensa, em que houve ameaças em relação à manutenção das alianças políticas, a Comissão reiterou sua posição anterior (COMISSÃO DE IMPLANTAÇÃO, 1999a).

$\mathrm{Na}$ semana seguinte, o assunto voltou à pauta, com a presença dos coordenadores dos módulos em questão e também com a presença do diretor do CCS. Apesar de muita resistência de alguns membros, a decisão foi revertida, acatando-se o posicionamento do colegiado. Foram nomeados os co-tutores para os referidos módulos e foi assegurada a participação dos professores de fora da área da saúde como tutores.

Esse conflito - que fragilizou a Comissão - e uma forte mobilização dentro e fora do colegiado no sentido de que o vice-coordenador assumisse a candidatura a coordenador do colegiado, liquidaram a possibilidade - até então crescente - de que um dos membros da Comissão de Implantação postulasse esse posto.

Depois desse episódio, houve uma perda importante de poder e prestígio da Comissão e, a partir do ano 2000, foram diminuindo as disputas entre a Comissão de Implantação e o Colegiado. O novo coordenador do Colegiado fez com que a Comissão se ativesse a seu papel executivo de acompanhar as tarefas práticas do processo de implantação.

Em 2002, já que estará terminado o processo de implantação das 4 séries, a Comissão se extinguirá automaticamente. E todas as novas funções de coordenação e mobilização serão cumpridas através do Colegiado (que também estará sob nova direção). Mas, há muita dúvida a respeito da estrutura que o Colegiado deveria assumir para não perder a ligação com os Departamentos e ao mesmo tempo dar cabida à nova estrutura de gestão do curso. 


\subsubsection{A falta de uma direção estratégica}

Foram muito dinâmicos os dois primeiros anos de implantação, marcados por forte mobilização, por grande esforço para a superação dos desafios técnicos e políticos que a nova proposta trazia.

O Colegiado conseguiu tratar e equacionar muitas das questões críticas relacionadas com as normas necessárias para a operação do novo currículo. A participação direta de seus componentes no processo de implantação foi estratégica para que fossem encontradas maneiras de superar resistências dentro dos departamentos, com exceção da Clínica Cirúrgica.

Algumas outras decisões, que dependiam da direção do Centro, tardaram a ser tomadas ou nunca o foram. Problemas de infraestrutura - como o do processamento das informações geradas através do processo de avaliação - nunca foram resolvidos e acabaram tendo uma repercussão importante.

Nunca ficou claramente estabelecida a competência de acompanhar, cuidar do processo como um todo. Seria do diretor do Centro - porque ele é médico? Seria do Colegiado? Essa indefinição contribuiu para o não enfrentamento de problemas críticos como a adesão dos clínicos, a capacitação docente e a avaliação.

\section{A adesão dos clínicos}

O grande problema da adesão dos clínicos (professores da clínica médica, da cirurgia, da pediatria e da ginecologia-obstetrícia), que era político e administrativo e exigia a ação da direção do Centro, foi arrastado até o limite e tratado exclusivamente no campo administrativo. Basicamente foi resolvido através de negociações miúdas, caso a caso. Somente no final de 2001 é que finalmente se decidiu pela implantação das planilhas de carga horária - que haviam sido propostas pelo Colegiado há 2 anos - para dar conta de colocar esses professores para trabalhar na graduação. 
Havia uma expectativa de que através do trabalho de capacitação docente se poderia chegar a conquistar a adesão os clínicos. Mas seria um equívoco imaginar que se poderia converter os clínicos somente com a capacitação docente, pois isso correspondia a reduzir a abrangência da mudança. Pois, como diz TURINI (2000), a mudança na medicina não é apenas uma mudança de metodologia pedagógica (método tradicional, pedagogia da transmissão $X$ metodologia ativa de ensinoaprendizagem, PBL e problematização).

Ou seja, para conquistar os clínicos para uma proposta de mudança será necessário discutir a prática clínica, entrar no hospital, repensar sua inserção no SUS, repensar não somente a organização dos estágios do internato, mas as relações que se estabelecem aí dentro (com os pacientes, entre internos e docentes, entre todos os profissionais). Então, a oposição está certa: a reforma está se aproximando de terrenos sagrados - o hospital, a organização da prática clínica, o papel das especialidade - parece que eles percebem isso com clareza.

E como se comporta(m) a(s) corrente(s) mudancista(s)?

Conhecendo a correlação de forças que havia à época da aprovação das mudanças, houve uma opção por não precipitar qualquer colisão com a oposição à mudança (daí o acordo em relação ao internato, por exemplo). Esperava-se que com o tempo, com a implementação da mudança, fosse possível ir ampliando a adesão, para mais tarde se poder partir para determinados e inevitáveis confrontos. Esse cálculo estava corretíssimo.

O problema foi que, ao perceber que os passos imaginados não estavam acontecendo, o grupo condutor da mudança tenha ficado esperando que alguma coisa espontaneamente acontecesse. Ou seja, a estratégia originalmente imaginada não funcionou, mas não se colocou outra no lugar...( FEUERWERKER, 2000).

Se uma parte significativa do corpo docente da área clínica está inserida na universidade para cumprir funções assistenciais, os caminhos para levá-los a uma reflexão clínica não poderiam estar situados somente no campo da docência e da investigação. Se a prática privada dos médicos em Londrina é importante e 
continua sendo a principal referência de qualidade para os clínicos, estratégias baseadas exclusivamente em ações no sistema público tenderiam a não mobilizar ou entusiasmar esses profissionais. Se a correlação de forças internamente à universidade não era favorável a determinados aspectos do processo de mudança, seria importante voltar a utilizar a potência da parceria para colocar outros atores estratégicos em cena e reconstruir o cenário.

Num seminário da Rede UNIDA, realizado em Londrina no ano 2000, chegou-se à conclusão de que para conseguir efetivamente mudar, seria indispensável ultrapassar os limites da "reforma acadêmica de graduação" e avançar para o terreno da organização da prática médica e da formação médica como um todo (REDE UNIDA, 2000c).

Mas nada foi feito, pois prevaleceu o já descrito imobilismo diante das questões críticas, que se explica por uma análise limitada da correlação de forças. Ante a evidência de que existia uma oposição, considerou-se não haver força política para qualquer iniciativa: se o equilíbrio a favor da mudança era delicado, ele não resistiria a nenhum tipo de confronto. $O$ resultado foi que as forças mudancistas deixaram de ocupar espaços estratégicos e ficaram acuadas.

Existe oposição, mas também existe poder de atração. Ações mais ousadas de atração, sensibilização e mobilização poderiam explicitar o conflito latente, mas levariam a acumular poder e poderiam mudar a correlação de forças.

Seria importante entender que os "clínicos" não são homogêneos; que uma parte deles, que era "indiferente", agora está sinceramente interessada em participar da nova proposta e pode ser ganha com novas estratégias:

"Agora não tem mais onde especializar... O que está acontecendo do ponto de vista da prática é exatamente o contrário: a especialização chegou a tal ponto, que virou irracional, perdeu a capacidade de resolver os problemas.. Os pacientes não agüentam mais e muitos médicos também não. Por exemplo, o pessoal da geriatria surgiu com mais força, buscando por integração. Na prática deles e também no modo de ensinar...Lembra como foi o módulo de envelhecimento?" (grupo focal dos docentes L). 
Então eu acho que a gente tem uma grande coisa a favor, que é justamente o fato que do ponto de vista da realidade nunca teve tanto interesse por parte dos próprios clínicos de estarem recuperando certos conhecimentos, buscando uma ação mais integral" (grupo focal dos docentes L).

Isso diminuiria, sem dúvida, o poder de pressão do grupo oposicionista e aumentaria os graus de liberdade do grupo mudancista. A oposição sabe disso. Apesar de francamente minoritários, os professores que não aderiram ao novo curso atuam ativamente e fazem isso especialmente de duas maneiras.

Na primeira linha de ação, o alvo são os estudantes, que são bombardeados, com o objetivo de minar sua confiança na metodologia, na competência que estão adquirindo, através de ameaças literais em relação à sua entrada no hospital: "no internato esses estudantes vão ver o que é bom, vão ser testados para valer", sendo que os "juízes" são obviamente mal-intencionados: "eu fico até com dó deles (os estudantes), porque eles no internato vão ser jogados na boca do leão" (...) (grupo focal dos docentes L).

Na segunda, o alvo é a influência das especialidades na organização das práticas, que é defendida através do embargo sobre a discussão do internato, através da rejeição a um compromisso maior da UEL com a Saúde da Família, da rejeição às propostas dos estudantes para "renovar" o juramento de Hipócrates etc. (entrevistado L2); (UNIVERSIDADE, 1999a).

Eles ativamente agem e aumentam seu poder de fogo - que provavelmente nem corresponde à sua força real. Por exemplo, somente 8 a $10 \%$ dos professores declararam-se abertamente contra a nova proposta - achando que o ensino é pior que o tradicional, que é um retrocesso em relação ao que tinham antes (AGUIAR, 2001). A "ameaça" de retorno ao tradicional, portanto, praticamente não tem sustentação. 


\section{O trabalho de capacitação docente}

Há várias evidências de que o trabalho de capacitação docente não pode ficar restrito à capacitação de tutores. Existem outras novas funções neste novo currículo que também necessitam de apoio e de reflexão crítica: construção dos módulos, consultoria, instrução em habilidades, instrução no PIN, por exemplo (AGUIAR, 2001).

Se pensada nos moldes da educação permanente, a capacitação docente poderia ser um interessante espaço de reflexão crítica sobre a prática e de construção de propostas inovadoras.

A capacitação docente também poderia cumprir um papel chave na realimentação do debate educacional dentro do curso de medicina e do CCS, que é uma necessidade urgente (entrevistado L2).

A pobreza do debate atual e a falta de estudo a respeito podem levar a um empobrecimento da proposta pedagógica e a uma mistura inaceitável de conceitos. Uns falam em pedagogia para aprendizagem de adultos, em Paulo Freire, em educação transformadora (CAMPOS \& BADUY, 2000); outros falam em andragogia (uma "pedagogia" do adulto, ramo que tem maior desenvolvimento na última década, impulsionado pela necessidade da educação continuada e do desenvolvimento do capital humano pelas empresas) e dizem que o aprendizado independente é estimulado e recompensado (UNIVERSIDADE, 1997). Afinal, pedagogia crítica não combina muito com estímulo e recompensa...

\section{O trabalho de avaliação}

Se há problemas na concepção e prática da avaliação dos estudantes, em relação à avaliação sistemática do programa há um vazio completo.

Dentro da Comissão de Avaliação não há pessoas com formação específica em avaliação e, portanto, faltam elementos para avançar no trabalho em relação aos estudantes e na avaliação do programa. 
A avaliação poderia cumprir um papel decisivo para a criação de diversos momentos e espaços de reflexão, avaliação e construção coletiva das propostas de mudança, envolvendo a maior participação possível a cada momento.

Ao início do projeto UNI, houve muito cuidado e compreensão a respeito da necessidade de a mudança ser um processo participativo, mas houve descuido desse trabalho durante os últimos tempos da implantação (grupo focal dos docentes L); (entrevistados L2, L3 e L5).

Após o final da greve, abriu-se um período de importantes sucessões dentro do CCS, do Hospital Universitário e de toda a universidade. A sucessão, os jogos de poder, o PROMED, a possibilidade de real inserção do HU na rede de serviços, a aliança com os serviços na capacitação em saúde da família e na educação permanente dos profissionais da rede são todos elementos que podem favorecer a construção de um cenário mais favorável.

O desafio agora é sair do imobilismo. 


\section{O processo de mudança em Marília}

\subsection{A cidade de Marília}

A região em que se encontra Marília, no oeste de São Paulo, começou a ser ocupada em 1923, quando forasteiros, principalmente paulistas, buscaram a área, atraídos pela terra de boa qualidade. Sucessivamente, foram sendo estabelecidas fazendas, depois foi se configurando um conglomerado, de modo que já em 1926 havia uma comarca e finalmente o município em 1929.

A atividade econômica básica era agrícola; cultivava-se particularmente o café e depois o algodão. Já na primeira metade dos anos 30 instalaram-se ali as duas primeiras indústrias - de óleo - que provocaram um salto no processo de urbanização local e no desenvolvimento da cidade como pólo regional.

$\mathrm{Na}$ década de 60/70 Marília sofreu uma retração do incremento populacional em função da decadência das culturas de café, algodão e amendoim. Desde então, passou a haver predomínio da pecuária em relação à agricultura.

Um novo ciclo industrial iniciou-se em meados dos 70 , em razão principalmente da instalação de indústrias de alimentos. Nos últimos anos, a cidade tem crescido como pólo regional de serviços, setor intensamente reforçado pela instalação das universidades na cidade.

Atualmente há 400 indústrias (as mais importantes, de metalurgia e alimentos) e 1227 propriedades rurais ( $74 \%$ das quais menores que 100 hectares). Pessoal Ocupado na Indústria: 12.018; Pessoal Ocupado no Comércio: 9.700 e Pessoal Ocupado em Serviços: 16.600.

Segundo o Censo de 2000, são 197.153 habitantes, dos quais $96 \%$ na zona urbana. A taxa de crescimento populacional é de 2,46 e já há 9,7\% de idosos. São 49.018 moradias, $99 \%$ das quais servidas por água encanada e $95 \%$ por esgoto.

Os principais problemas ambientais estão concentrados na zona periférica da cidade, motivados por acumulação de lixo e por contaminação da água por esgoto doméstico. 
Segundo dados da Fundação Seade, Marília no final da década de 90 tornou-se um município-pólo de desenvolvimento, com as dimensões de longevidade e escolaridade superiores às do estado de São Paulo (SEADE,2002).

\section{Educação}

Há 40 estabelecimentos de ensino pré-escolar com 8.995 alunos, 53 de educação fundamental com 30.700 alunos, 20 de ensino médio com 10.531 alunos e 4 de nível superior com 18.000 alunos (muitos estudantes vindos de fora, de outras áreas de São Paulo e de outros 15 estados). A taxa de analfabetismo é de 13,3\%.

Saúde

Marília dispõe de uma boa rede de serviços de saúde, capaz de dar cobertura às necessidades da população. São 17 UBS e 8 USF; 2 pronto-socorros e 1 pronto-atendimento, sendo que os leitos de urgência e emergência são controlados por uma Central, gerenciada pela Secretaria Estadual de Saúde. Há também 7 unidades de atendimento especializado, 5 hospitais para atenção de nível secundário e terciário, 3 dos quais privados sem fins lucrativos.

$O$ coeficiente de mortalidade infantil vem diminuindo significativamente em Marília desde a década de 80 : de valores acima de 50 por mil nascidos vivos passou-se a 17,65 no ano 2000. A Figura 22 mostra essa evolução: 
Figura 22 - Evolução da Mortalidade Infantil e seus componentes em Marília de 1980 a 2000.

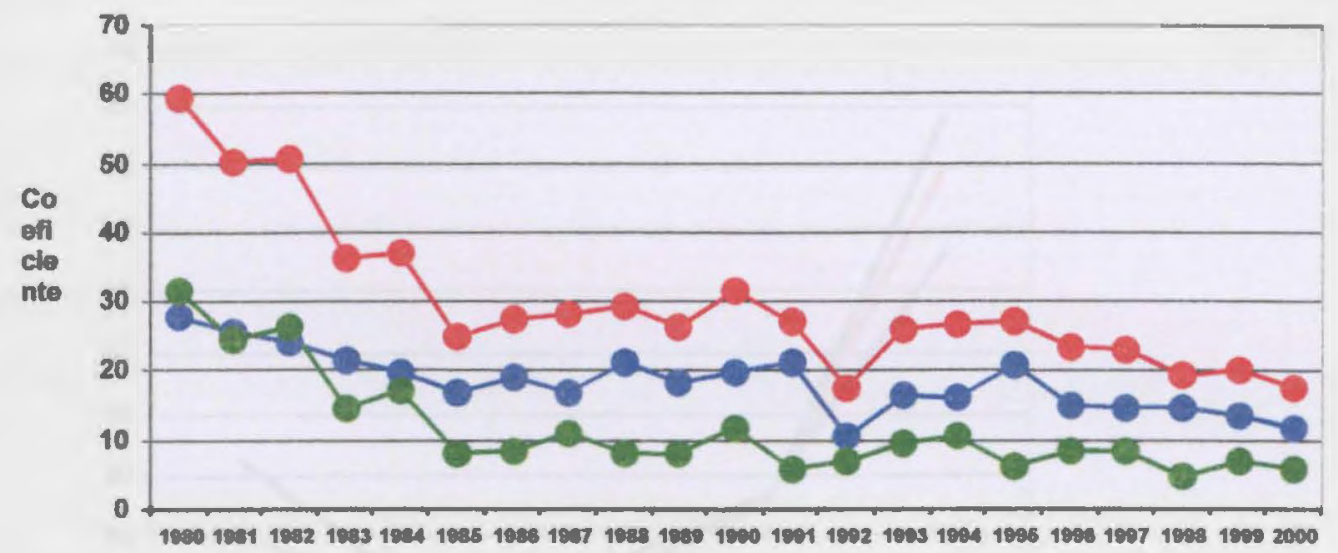

fonte: $80-89$ SEADE

90-98 DIR 14 MARILIA

99 EM DIANTE SMHS MARILIA

$$
\rightarrow \text { M. Infantll } \rightarrow \text { M. Neo-natal } \rightarrow \text { M. InfantII tardia }
$$

Apesar do progresso evidente, o coeficiente de mortalidade infantil de Marília ainda está acima do coeficiente do estado de São Paulo, que é de 16,97 por mil nascidos vivos no ano 2000 .

No ano 2000, as doenças cardio-circulatórias foram a principal causa de morte (24,41\%); as neoplasias ficaram em segundo lugar entre as causas conhecidas, seguidas pelas causas externas.

A figura 23 mostra a evolução da mortalidade proporcional de 1990 a 2000 , com progresso positivo das relaçôes: 
Figura 23 - Mortalidade proporcional - Curvas de Nelson de Moraes em Marília nos anos de 1980, 1990 e 2000.

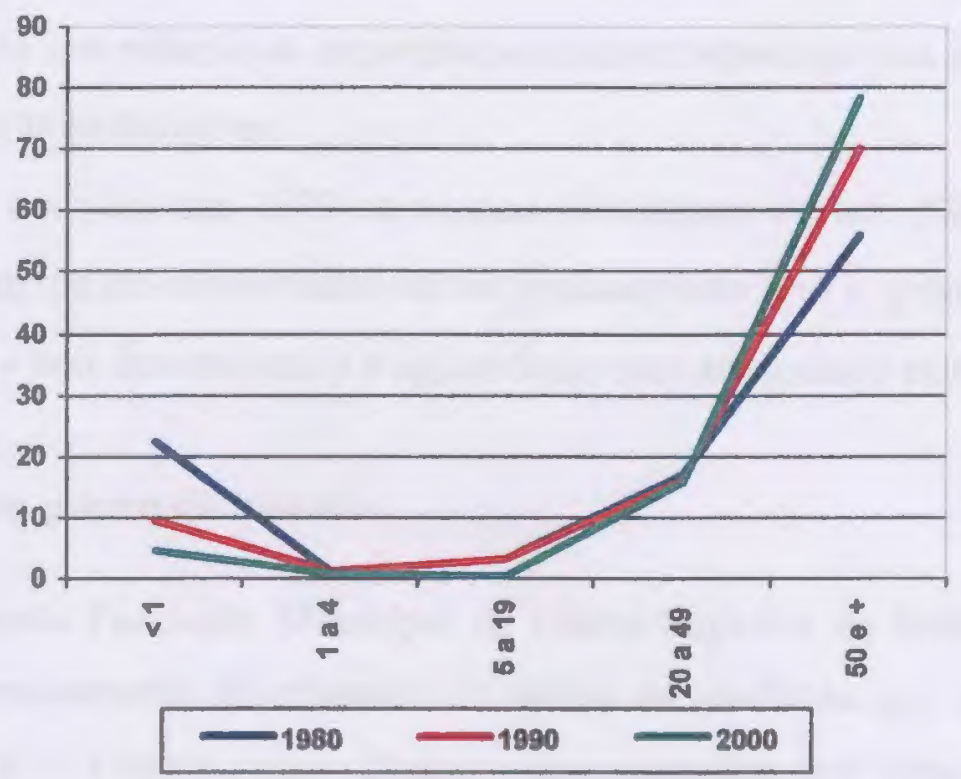

Concluindo o perfil

É uma cidade com economia dinâmica e bons padrões de qualidade de vida. Foi a cidade que mais cresceu no estado de São Paulo em 1999.

\subsection{A FAMEMA}

A FAMEMA (Faculdade de Medicina de Marília) é uma faculdade estadual, vinculada diretamente à Secretaria Estadual de Ciência e Tecnologia, que oferece cursos de medicina e de enfermagem, com 80 e 40 vagas, respectivamente. Além dos cursos de graduação, atualmente há 24 programas de residência médica, duas especializações e dois cursos de aprimoramento.

Conta atualmente com 234 docentes, dos quais 16 estão em dedicação exclusiva, 107 são contratados por 40 horas semanais, 96 têm contratos de 20 a 30 horas e 13 são contratados por menos de 20 horas semanais. Atualmente 112 dos 
docentes são especialistas, 69 mestres, 48 doutores, 3 pós-doutores e 3 livredocentes.

$\mathrm{Na}$ avaliação das condições de oferta, a FAMEMA foi qualificada como tendo $\mathrm{CB}$ (condições boas) em qualificação do corpo docente, CMB (condições muito boas) em relação à organização didático-pedagógica e $\mathrm{CB}$ (condições boas) em relação às instalações.

No provão, em 1999 os alunos obtiveram A, em 2000 B e em 2001 C. A primeira turma do novo curso vai se graduar este ano e, portanto, vai submeter-se ao Provão - seu desempenho é aguardado com ansiedade por todos.

\subsubsection{Um pouco de história}

A então Fundação Municipal de Ensino Superior de Marília foi criada em 1967 dentro do movimento de expansão do ensino de medicina que ocorreu nessa época. A Faculdade e o Hospital das Clínicas eram mantidos por uma Fundação Municipal, composta por uma Diretoria (de 4 membros, não ligados à área acadêmica) e por um Conselho de Curadores (com 18 membros). Essa Fundação apresentou desde logo importantes dificuldades gerenciais e financeiras (PADILHA, 1996).

A Faculdade, em si, enfrentava os mesmos problemas que todas faculdades de medicina privadas criadas nesse período: muitos docentes de tempo parcial, com enormes dificuldades para atualização e com baixa qualificação, biblioteca limitada e desatualizada, poucos laboratórios, equipados de maneira muito limitada, baixíssimo desenvolvimento das atividades de investigação e também da pós-graduação (SILVA FILHO, 1994).

Como ponto forte, um grupo dirigente que assumia compromissos com a saúde pública, que deu início à criação dos serviços básicos de saúde na cidade e manteve relações de cooperação com a secretaria municipal de saúde desde sua criação.

$\mathrm{Na}$ década de 80 foram desenvolvidas, de maneira sistemática, experiências de integração docente-assistencial e uma aproximação com o movimento IDA (PROJETO PIDA), o que ajudou a dinamizar o debate e as buscas de alternativas dentro da escola (KOMATSU et al, 1997b). Particularmente no curso de enfermagem houve uma opção radical pela integração com os serviços e as docentes cumpriam metade de sua jornada na 
faculdade e a outra metade nos serviços (básicos ou hospitalares), contribuindo para ampliar a capacidade gerencial da rede.

No início dos anos 80 , em meio a uma importante crise financeira da Fundação, houve uma importante mobilização dos docentes, que decidiram ser fundamental uma participação mais ativa na direção da Fundação. Depois de uma greve prolongada, essa articulação foi conseguida. Em 1983, foi mudada a composição da diretoria da Fundação, que passou a ser composta por professores da FAMEMA, tornando possível mobilizar todo o corpo docente para a solução dos problemas e trabalhar de maneira articulada a gestão dos aspectos acadêmicos e administrativos (KOMATSU et al, 1997b).

A partir de 1983, portanto, um grupo mais dinâmico assumiu a liderança da faculdade. Esse grupo, inicialmente coeso, diante das dificuldades para encontrar soluções para os problemas da instituição, foi se dividindo ao longo do tempo e deixando marcada a história da FAMEMA por importantes conflitos e disputas de poder (entrevistado M1).

Durante a campanha eleitoral para governador em 1990, o candidato mais tarde eleito havia assumido compromisso público com a estadualização da faculdade. Essa era uma antiga reivindicação e uma possibilidade de encontrar saídas para a crônica falta de recursos que a instituição enfrentava.

Com base nessa promessa, em 1993 foi desencadeado pelos estudantes, com apoio da direção da instituição e de alguns poucos docentes, o movimento pela estadualização. Os estudantes organizaram-se para "perseguir" o governador: onde quer que ele fosse havia um grupo de estudantes de Marília, com faixas e cartazes, reivindicando a estadualização, relembrando o compromisso assumido (entrevistado M1).

Ao longo da mobilização, já com a participação efetiva da direção da faculdade, foi incluída, na reivindicação junto ao governo, a estadualização da Faculdade de Medicina de Rio Preto, com objetivo de aumentar a força política da demanda. A pressão foi tanta que finalmente foram abertas negociações. 
Com o apoio de assessoria jurídica contratada pelo movimento, foi elaborado o projeto de lei que o governador finalmente apresentou à Assembléia Legislativa, com pedido de urgência, já que se aproximava o final de seu mandato (entrevistado M1).

Outra vez houve intensa mobilização dos estudantes (vários ônibus) e de alguns docentes, incluindo a direção da faculdade: acampamento na Assembléia, discussão com cada um dos deputados e com as direções partidárias, mobilização dos representantes da região. Finalmente, no final de 94, a estadualização foi aprovada e conseguiu-se que a faculdade fosse incluída no orçamento estadual do próximo exercício (entrevistado M1).

Nos primeiros anos após a estadualização, houve de fato um importante afluxo de recursos e a possibilidade de uma profunda reformulação institucional. Em razão de problemas políticos na relação com o governo estadual (motivados principalmente pela forte aliança da faculdade com a secretaria municipal de saúde em gestão que entrou em vários choques com a esfera estadual), em 2000 e 2001 voltaram a ocorrer problemas financeiros, motivados pelo não repasse de recursos. Em 2002, sob nova direção, foram dados alguns passos importantes na superação dessas dificuldades nas relações político-insitucionais e nos repasses financeiros.

\subsection{O projeto UNI}

Em 1991, quando chegou a carta convite para postular ao Programa UNI, a direção da faculdade enfrentava dificuldades políticas internas (pelo estilo de condução) e nas relações com a secretaria de saúde (porque havia disputas em torno da orientação das políticas de saúde entre grupos da faculdade e a prefeitura). Assim, a responsabilidade por articular a resposta à carta foi delegada a dois professores da Medicina Preventiva, um dos quais havia sido o diretor da faculdade no período imediatamente anterior (entrevistado M1). 
Com grande esforço se fez a articulação entre os docentes, com a secretaria municipal de saúde e com outras duas faculdades - a Faculdade de Saúde Pública da USP e a Faculdade de Educação da UNESP (Campus de Marília), com o objetivo de ampliar o espectro multiprofissional e dar maior consistência política à articulação (entrevistado M1).

Selecionados para uma primeira fase, foi necessário um grande esforço para ampliar a discussão dentro da faculdade e reunir elementos para a construção de uma proposta de trabalho, apesar do apoio recebido através de seminários e de consultores.

\subsubsection{A construção da parceria do ponto de vista político}

O primeiro ano de operação foi muito improdutivo. Apesar do enorme esforço para construir o projeto apresentado à Fundação Kellogg, não se havia conseguido traçar linhas claras de ação. Havia enormes dificuldades operacionais, falta de coesão política e de clareza em relação aos caminhos que se deveria seguir. Todos esses problemas afetavam tanto a construção da parceria como o trabalho de cada um dos segmentos (PROJETO, 1994).

Ao final de 1993, houve novas eleições para a direção da FAMEMA e, numa ampla aliança progressista, o primeiro coordenador do processo de articulação do UNI foi novamente eleito diretor, desta vez com uma expressiva maioria, que incluiu a unanimidade dos votos estudantis.

O primeiro passo então foi fazer um novo diagnóstico a respeito da situação da FAMEMA: os problemas em relação à qualidade dos cursos continuavam muito graves e, além disso, como já descrito anteriormente, havia uma séria crise financeira. A perspectiva que se colocou então foi "está tudo muito ruim. Se for para continuar assim, melhor fechar. Só há perspectiva de futuro se formos capazes de uma mudança radical, com muita qualidade" (entrevistado M1). 
Perseguindo esse objetivo, foi feita uma reorganização da estrutura do projeto, que buscava fortalecer a parceria no processo de decisão e dinamizar os processos. Foi eliminada uma instância intermediária que havia entre o Conselho Gestor e o nível operativo; fortaleceu-se a representação da comunidade através da incorporação de um representante do Conselho de Associações de Moradores e outro do Conselho Municipal de Saúde.Também foram feitas mudanças no núcleo de coordenação dos componentes, buscando maior articulação entre eles através da participação de representantes dos três componentes em todos os núcleos (PROJETO, 1994).

Novos quadros técnicos, basicamente pessoas que haviam se formado na FAMEMA e saído para novas experiências de trabalho e de formação, foram agregados ao projeto com o objetivo de tornar mais dinâmico e coeso o grupo dirigente (entrevistado M1).

Houve uma reestruturação e fortalecimento da área de avaliação, que a partir desse momento passou a cumprir um papel estratégico de apoio à gestão, principalmente da academia e dos serviços.

O planejamento estratégico passou a ser trabalhado em conjunto e foram definidas novas linhas de ação orientadas à superação de alguns dos problemas mais graves de cada componente, baseadas sempre no trabalho em parceria. Os diferentes núcleos foram apoiados na construção de suas linhas de ação e no planejamento das atividades, que passaram a ser acompanhadas cotidianamente pela equipe de avaliação (PROJETO, 1994).

Ao final de 1994 um acontecimento marcou profundamente a vida do projeto: a já mencionada estadualização da FAMEMA. A estadualização produziu uma importante mudança de ânimo no corpo docente, pois surgiram reais perspectivas profissionais e de futuro para a instituição. Novos recursos financeiros permitiram a resolução de alguns problemas crônicos de infraestrutura da instituição. A direção da faculdade tomou, como oportunidade para a implantação de mudanças, a necessidade de adequação da estrutura da faculdade 
às normas estaduais; nesse momento, os recursos e as idéias do projeto UNI foram usados como insumo fundamental para a orientação e construção das novas propostas (entrevistado M1).

Em 1995, foram oficialmente excluídos do projeto as Faculdades de Saúde Pública da USP e de Educação da UNESP, que nunca se haviam integrado efetivamente ao processo. Nessa época também o projeto foi novamente reestruturado, sendo adotada uma estrutura matricial, que implicava a existência de um Conselho Gestor, apoiado por um Núcleo de Apoio específico e mais três núcleos: de Apoio à Academia, aos Serviços e à Comunidade. Cada uma dessas instâncias contribuía com participantes para o desenvolvimento de 34 subprojetos. (PROJETO,1995).

Alguns meses depois, essa dinâmica foi reavaliada. Considerou-se que:

"o número de subprojetos dificultava o gerenciamento, embora tivesse possibilitado a participação ativa de um número significativo de novos atores. A grande diversidade dos projetos e a grande descentralização de poder contribuíram para um desenvolvimento pouco harmônico, implicando numa sobrecarga de trabalho para o núcleo de apoio à gestão" (PROJETO, 1996).

Decidiu-se então reduzir o número de subprojetos para 12. Todos os coordenadores dos 34 subprojetos participaram de uma oficina de trabalho para apropriação do método de análise de projetos. A partir desse marco, em mais três oficinas de trabalho, os subprojetos foram reescritos, alguns se converteram em linhas de ação de subprojetos redefinidos (PROJETO, 1996).

A secretaria municipal de saúde no período de 1993 a 1996 não tinha a dinamicidade e a criatividade como características importantes. Não havia interesse em avançar, por exemplo, na gestão do SUS e o município permanecia em gestão incipiente. A secretaria participava do projeto, abria espaço e aprovava as ações, mas não tinha projeto próprio para a organização do sistema. Academia e 
comunidade, então, davam o tom das ações desenvolvidas nas unidades básicas de saúde.

Em 1996 terminou a primeira fase do projeto UNI e houve uma grande mobilização para a construção da proposta para a segunda fase. Em função da estadualização e das estratégias de mobilização e formação que haviam sido adotadas, havia poder e massa crítica mobilizada, o que possibilitou que, para o segmento academia, fosse adotada a opção por uma mudança radical do modelo pedagógico e dos currículos dos cursos de medicina e de enfermagem.

No final desse mesmo ano, ocorreram eleições municipais e houve troca do partido no poder. Foi então nomeado secretário de saúde um professor da FAMEMA, sanitarista histórico, que havia tido ativa participação tanto na reforma sanitária como nos processos de mudança dentro da FAMEMA. Também na FAMEMA houve eleições, disputadas, e foi reeleito o então diretor pro-tempore para um novo mandato.

Iniciou-se, então, um novo período na parceria. Por um lado havia grande coesão política no grupo condutor, particularmente entre o secretário municipal de saúde e o diretor da FAMEMA. Por outro lado, a secretaria de saúde passou a ter projeto próprio e começaram a existir conflitos, especialmente no âmbito operacional: academia e comunidade passaram a ter que negociar com a secretaria de saúde, que agora não mais se deixava "colonizar" (PROJETO, 1998).

Por outro lado, tanto academia como os serviços entraram em um processo intenso de transformação. E apesar da forte aliança estratégica entre academia e serviços persistir e ser a base para algumas decisões importantes que foram tomadas, ocorreu uma espécie de movimento de introspecção dos dois parceiros que levou a que ambos se voltassem para dentro na construção de suas respectivas mudanças.

Já o segmento comunidade sofreu um processo de desestruturação. Em conseqüência de conflitos com o poder municipal e também de problemas na gestão de recursos, houve um profundo desgaste do coordenador do Conselho das 
Associações de Moradores, que acabou afastando-se do cargo e da coordenação do componente comunidade (PROJETO, 1998).

O Conselho em seguida desestruturou-se e deixou de existir na cidade uma organização comunitária de nível secundário que pudesse representar a comunidade no projeto UNI. A coordenação do segmento e o núcleo coordenador passaram a ser compostos por pessoas que, individualmente, realizavam trabalhos junto às comunidades, mas que por sua inserção individual tinham representatividade e capacidade de mobilização coletiva limitadas.

Desde então, a possibilidade de influência efetiva do segmento comunidade na direção do projeto diminuiu. Foram desenvolvidas inúmeras estratégias para tentar fortalecer esse componente, com resultados limitados.

No ano 2000 houve eleições municipais, com reeleição do prefeito e manutenção do secretário de saúde. Deu-se, a partir desse momento, uma retomada da ação articulada especialmente entre academia e serviços, passando a existir progressivamente uma participação ativa dos dois componentes em ambos os processos de transformação.

Em 2001, nas novas eleições para a direção da FAMEMA buscou-se configurar um arranjo de forças mais favorável às negociações com o governo estadual. Foi eleito para o cargo o anterior vice-diretor, que por razões políticopartidárias, teria melhores possibilidades de relação com o governo estadual. Manteve-se basicamente o mesmo grupo no poder, mas saiu da cena mais ativa o ex-diretor, que cumpria um papel de coesão importante dentro do grupo condutor.

As relações orgânicas de parceria entre a faculdade e a secretaria municipal de saúde e em menor intensidade com a comunidade estão mantidas e há muitos projetos estratégicos sendo conduzidos e construídos em parceria.

Inicia-se um novo período em que o grupo gestor vai ter que encontrar uma nova dinâmica de trabalho, já que, sem a presença ativa do ex-diretor, os conflitos e disputas terão que ser resolvidos sem a sua mediação, que sempre foi fundamental. Também será importante encontrar outros núcleos propulsores, que 
sejam capazes de manter a dinamicidade do processo, porque esse também era um papel cumprido pelo ex-diretor.

\subsubsection{A construção da parceria na prática}

Como mencionado, o primeiro ano de desenvolvimento do projeto foi marcado por muitos impasses, indefinições e por uma profunda incapacidade de operacionalização.

Em 1994, partir das novas definições já mencionadas, foi feito um enorme esforço de mobilização e sensibilização, utilizando-se para isso de múltiplas ofertas de capacitação para todos os componentes, com temas variados, definidos em função das prioridades identificadas. Foram feitos também seminários viajeiros que são viagens programadas para possibilitar o conhecimento de outras experiências em áreas consideradas estratégicas - para outros projetos UNI dentro e fora do país (PROJETO, 1994); (PROJETO, 1995).

$\mathrm{Na}$ academia, como veremos mais detidamente mais adiante, os esforços foram dirigidos principalmente em três sentidos: capacitação pedagógica, criação de infraestrutura adequada para docência em novos moldes e desenvolvimento de atividades docentes nas unidades básicas de saúde, envolvendo atendimento ambulatorial nas áreas de clínica médica, ginecologia-obstetrícia, cirurgia (pequenas cirurgias) e psiquiatria. Para fortalecimento da articulação com os serviços, dois profissionais dos serviços foram incorporados às atividades docentes (PROJETO, 1994).

A rede de serviços públicos de saúde em Marília nessa época era composta por um número significativo de unidades, mas padecia de muitos problemas de qualidade, tanto na esfera da gestão como da atenção. Não havia descentralização efetiva, as unidades básicas não tinham gerência configurada (uma enfermeira era responsável simultaneamente pela gerência de 2 a 3 unidades), não havia 
planejamento do trabalho e os profissionais não estavam tecnicamente bem preparados (PROJETO, 1994).

Com o apoio do UNI, foram criadas gerências em cada unidade básica e desenvolvida capacitação nessa área através do GERUS. Foi feito trabalho de territorialização em todas as unidades e iniciado o debate sobre modelo assistencial.

Para o segmento comunidade, o investimento foi feito na criação de conselhos locais de saúde nas várias unidades, na subseqüente capacitação dos conselheiros e na abertura de espaços de participação direta no incipiente processo de planejamento local das unidades básicas de saúde (PROJETO, 1994).

Em 1995 houve a implantação do PIMEC (Programa Integrado de Medicina e Enfermagem com base comunitária), através do qual, tomando por base a experiência de Londrina no PEEPIN, os estudantes do $1^{\circ}$ ano das duas carreiras realizavam trabalhos sobre problemas prioritários de saúde e desenvolviam seus estudos através da metodologia da problematização (PROJETO, 1995).

Também houve um trabalho conjunto, entre academia e serviços, de redesenho da atenção em saúde materna, da criança e do adulto nas unidades básicas de saúde, buscando criar um cenário de atenção integral de melhor qualidade em que os estudantes do $4^{\circ}, 5^{\circ}$ e $6^{\circ}$ anos foram inseridos.

Foi desenvolvido por uma equipe da FAMEMA um novo sistema de informação para a rede de serviços de saúde, que foi totalmente informatizada. Sistema de informação inovador, integrador, que permite trabalhar os dados por unidade de saúde, foi utilizado mais tarde por vários outros municípios (PROJETO, 1995).

Em 1997, primeiro ano da nova gestão municipal e da implantação do novo currículo de medicina, uma assessoria técnica para a secretaria de saúde foi contratada com recursos do projeto. Foi possível, então, um intenso processo de modernização e atualização da secretaria, que rapidamente passou à gestão plena. 
Através desse processo foi possível também ao secretário de saúde retomar sua participação ativa no cenário nacional da construção do SUS.

Em 1999, com a implantação de várias equipes de saúde da famúlia no município, foi desenvolvida uma interessante estratégia em relação aos profissionais médicos da saúde da família. Eles receberam a capacitação para tutores - parte do necessário para a implantação da metodologia de Aprendizagem Baseada em Problemas - e participaram como co-tutores de todas as unidades da $4^{\mathrm{a}}$ série do curso de medicina, cumprindo papel bastante ativo na introdução do debate de elementos importantes para a atenção integral e para a contextualização da discussão dos casos clínicos.

Houve também um remanejamento dos médicos das unidades básicas de saúde, que foi planejado de maneira conjunta pela faculdade e pela secretaria e teve como objetivo garantir a presença de profissionais capacitados e com vocação didática em todas as unidades. Esses profissionais passaram a ser responsáveis pela supervisão do trabalho dos estudantes e a receber uma remuneração específica por esse trabalho.

Também no curso de enfermagem os profissionais dos serviços, tanto os chamados assistenciais como os gerentes, foram assumindo cada vez maior protagonismo no trabalho dos estudantes do $4^{\circ}$ ano. No final do ano 2001 , em oficinas de trabalho realizadas com docentes e profissionais de enfermagem dos serviços, ficou decidido que as profissionais da rede se encarregarão do acompanhamento do trabalho das estudantes e semanalmente haverá reuniões de supervisão com as docentes, das quais participarão todos, estudantes, docentes e profissionais dos serviços, para uma reflexão conjunta sobre as práticas realizadas.

O Hospital das Clínicas da FAMEMA foi totalmente integrado ao sistema municipal de saúde, participando do sistema de central de vagas para internação nas várias áreas e funcionando como retaguarda para consultas de especialidades.

Com a expansão do programa de Saúde da Família na cidade, surgiu a necessidade de intensificar o processo de capacitação profissional nessa área. A 
FAMEMA assumiu a criação de um curso de especialização, cujo conteúdo foi definido em parceria e que será desenvolvido em módulos, utilizando a metodologia da aprendizagem baseada em problemas, com ampla participação dos professores de todas as áreas da faculdade.

Sem organização própria e autônoma da comunidade que lhe garantisse sustentação, a participação popular nos conselhos de saúde sofreu um importante processo de enfraquecimento na maioria das unidades de saúde. São os agentes comunitários de saúde e outras lideranças, como as das associações de moradores, que cumprem o papel de trazer à tona os principais problemas de cada área.

Mais recentemente, o trabalho do segmento comunitário do projeto UNI concentrou-se fortemente numa iniciativa de desfavelamento (que foi proposta e é coordenada por esse componente) e em iniciativas de geração de renda, ambas bem sucedidas.

\subsection{O trabalho no segmento acadêmico}

\subsubsection{As estratégias}

As grandes fortalezas da FAMEMA, ao início do projeto UNI, eram sua história de compromisso com os serviços de saúde e a existência de pessoas com visão estratégica. $\mathrm{Na}$ proposta elaborada inicialmente para participação no programa UNI havia um diagnóstico muito claro a respeito dos problemas e das debilidades existentes.

No primeiro ano de implantação do projeto, investiu-se na construção de uma proposta alternativa de currículo, que, no segundo ano, sob nova gestão, foi abandonada. Fundamentalmente a rejeição a essa iniciativa se deu porque se considerou que uma proposta de mudança teria que ser construída com a participação ativa dos docentes e com uma base muito mais sólida em relação às concepções pedagógicas. 
Foi feita, então, em março de 1994, uma oficina de planejamento estratégico que definiu como linhas fundamentais de ação a capacitação pedagógica, o deslocamento de atividades docentes para as unidades básicas de saúde e o reequipamento da biblioteca (PROJETO, 1994).

A Clínica Médica realizava atividades nas unidades básicas com os alunos do $4^{\circ}, 5^{\circ}$ e $6^{\circ}$ anos por um período de no mínimo 6 e no máximo 15 semanas (no quarto ano). A Pediatria trabalhava com alunos do $4^{\circ}$ e do $5^{\circ}$ anos, com a mesma carga horária e a Cirurgia levava estudantes de $5^{\circ}$ e $6^{\circ}$ anos para atividades de pequena cirurgia e cirurgia ambulatorial por períodos de 8 e 6 semanas respectivamente.

Buscaram-se recursos de capacitação e assessoria na área pedagógica em diversos núcleos e centros nacionais e internacionais. Educação centrada no estudante, planejamento curricular, qualidade no ensino superior, estratégias de reforma curricular (realizado em Londrina), reflexão crítica sobre a prática pedagógica nos processos de capacitação nos serviços de saúde, formação de agentes de mudança foram alguns dos temas e das iniciativas de capacitação nessa área (PROJETO, 1994).

Foi criado também um Núcleo de Pesquisa e Epidemiologia Clínica e estabelecidos convênios que criavam condições para a capacitação progressiva de docentes nessa área. O principal objetivo dessa iniciativa era estimular nos docentes a capacidade de seleção de material, de leitura crítica, de aprendizagem independente e de investigação.

A biblioteca foi reformada, teve seu acervo ampliado e seu quadro de funcionários fortemente capacitado para que pudessem ser implantadas estratégias mais modernas de gestão da informação (PROJETO, 1994); (PROJETO, 1995); (PROJETO, 1996).

No segundo ano do projeto, constituiu-se o Grupo de Apoio ao Componente Acadêmico, composto pelos coordenadores dos subprojetos da área acadêmica e também por outros elementos interessados em educação médica. 
Coordenado pelo diretor da FAMEMA, o Grupo constituía-se numa estrutura informal, mas com caráter deliberativo. Através do trabalho desse grupo tornou-se possível "garantir direcionalidade ao Projeto Acadêmico; propiciar articulação das atividades, evitando as ações pontuais; integrar atividades dos cursos de medicina e enfermagem e constituir um fórum de estudo sobre educação médica" (PROJETO, 1995). As reuniões do grupo eram quinzenais e abertas à participação de todos os componentes.

Foram criados vários subprojetos para o desenvolvimento dos trabalhos nas áreas de revisão curricular; avaliação discente, docente e institucional; articulação ensino-serviço-comunidade; epidemiologia clínica. Vários desses subprojetos recebiam apoio de dois outros subprojetos - o de capacitação pedagógica e o de incorporação tecnológica.

As câmaras do ciclo básico, clínico e internato foram ampliadas com a participação de pessoas interessadas ou consideradas formadoras de opinião. Decidiu-se introduzir algumas mudanças na estrutura da $1^{\text {a }}$ e da $4^{\text {a }}$ séries, consideradas pontos críticos do currículo.

Na primeira série, a carga horária de Anatomia foi reduzida em 19\%, tempo esse que foi convertido em Áreas Verdes (seguindo a estratégia criada em Londrina), nas quais foram oferecidos cursos de inglês e de informática.

Na quarta série houve uma redução de $33 \%$ na carga horária, a introdução de novos conteúdos como epidemiologia do envelhecimento, interações medicamentosas, politraumatismo, depressão, fadiga, relação médico-paciente, avaliação nutricional etc. Além disso, foram destacadas 108 horas para a discussão de 27 grandes temas, que integravam 3 a 5 especialidades cada um (PROJETO, 1995). Houve também a tentativa de introduzir a discussão de conteúdos sob forma de problemas.

Essas inovações esbarraram com algumas dificuldades importantes como: "a inadequação do espaço físico para o trabalho com grupos menores de alunos, a insatisfação de alguns docentes com a perda de carga horária, a falta de articulação entre alguns docentes para a discussão dos grandes 
temas e a estrutura departamental que dificultava a gerência do processo" (PROJETO, 1995).

Foi definida também uma estratégia que buscava propiciar o envolvimento progressivo de toda a comunidade acadêmica na construção de uma proposta de mudança e que consistia na realização de uma pesquisa visando a revisão curricular. Essa estratégia foi adaptada de iniciativa semelhante realizada na Universidade Federal do Paraná (PROJETO, 1995).

Para tanto, foram realizados quatro seminários sobre o Perfil do Médico a ser formado, Modelo Pedagógico, Currículo Nuclear e Internato. Foram enviados convites individualizados para todos os docentes e houve dispensa formal das atividades de ensino e assistência para docentes e discentes nos períodos dos seminários. Foram também convidados a participar desses eventos os profissionais dos serviços de Marília e representantes dos projetos UNI de Londrina e de Botucatu.

Houve participação de $53 \%$ dos docentes (o que corresponde a 65 ), sendo que $7 \%$ participaram de todos os seminários, $12 \%$ participaram de três, $23 \%$ participaram de dois e $58 \%$ participaram de um. A participação dos estudantes foi mais expressiva no tema Perfil do Médico, mas em todos os casos contribuiu significativamente para o enriquecimento das discussões (PROJETO, 1995).

Todos os seminários foram gravados e posteriormente serviram de base para a elaboração de documentos-síntese, distribuídos para todos os docentes. A partir dos conceitos e temas discutidos nesses seminários, foi elaborado um questionário que teve como objetivo levantar os elementos fundamentais que deveriam nortear a elaboração do novo currículo.

A população-alvo da pesquisa consistia de: docentes (165), estudantes (489) e ex-alunos da faculdade (284), compondo um universo de 1028 pessoas (PROJETO, 1995). As perguntas investigavam a concordância ou discordância em relação a proposições inovadoras sobre perfil do profissional a ser formado, 
adoção de um currículo de base comunitária e da metodologia da aprendizagem baseada em problemas.

Foram enviados 938 questionários e recebidos de volta 360 (34\% dos questionários dos estudantes, 69\% dos docentes e 29\% dos ex-alunos) (PROJETO, 1996). A partir da análise das respostas, foi elaborada uma carta síntese, que foi distribuída a todos os estudantes e docentes. Também foi elaborado um documento analítico para ser discutido no Conselho Departamental (PROJETO, 1996).

Foi também realizada uma pesquisa junto aos docentes do básico, buscando identificar suas posições em relação à interdisciplinaridade, ao ensino baseado em problemas e à própria existência dos ciclos básico e profissionalizante.

Essas investigações serviram de substrato para a definição das estratégias para a construção e implementação do novo projeto acadêmico.

Prosseguiam também as atividades de capacitação pedagógica com "o objetivo de instrumentalizar os docentes para uma nova prática pedagógica e de articulação com os serviços de saúde e a comunidade e também para as atividades de pesquisa" (PROJETO, 1995).

Foram realizadas oficinas para a reflexão sobre a prática pedagógica, curso de formação docente, capacitação em problematização. Essas atividades envolveram em média a participação de 38-40 docentes e alguns deles foram depois incorporados ao Grupo de Apoio ao Componente Acadêmico.

Com o objetivo de instrumentalizar os docentes para as atividades de ensino-aprendizagem integradas com os serviços e comunidades foram realizados novos seminários-viajeiros, dos quais participaram 24 docentes de todas as áreas, com predomínio da enfermagem, da clínica médica e da cirurgia.

Progressivamente todos os docentes da área clínica foram sendo envolvidos em atividades na rede básica de serviços, desenvolvendo consultas, visitas e atendimento domiciliar, trabalhos em grupo e cirurgia ambulatorial. Houve dificuldades operacionais e também nas relações entre docentes e profissionais dos serviços. Uma das estratégias adotadas para sua superação foi a participação 
conjunta dos dois grupos de profissionais tanto no planejamento do programa docente como na elaboração do plano de trabalho das unidades (PROJETO, 1995).

Conforme foi havendo maior definição a respeito do modelo pedagógico e da proposta acadêmica que se pretendia adotar, as capacitações começaram a ser mais dirigidas. Passaram a ser orientadas basicamente para a construção de um currículo nuclear e para a metodologia da aprendizagem baseada em problemas (PROJETO, 1996).

Também as visitas e os seminários viajeiros foram orientados a esses objetivos. Foram feitas uma viagem a Maastricht (Holanda) e várias à Universidade de MacMaster, Canadá, com a qual se estabeleceu um convênio de cooperação técnica. Com base nesse convênio, dois professores dessa universidade passaram a visitar Marília com grande freqüência para prestação de assessoria técnica.

Esse trabalho se iniciou com uma oficina de trabalho, em dezembro de 95, sobre Aprendizagem Baseada em Problemas no ensino médico, que contou com a participação de 76 docentes, 15 alunos e alguns representantes do projeto UNI de Londrina. A segunda oficina de trabalho foi orientada à formação de tutores e a terceira ao desenvolvimento do processo avaliativo (PROJETO, 1996).

Paralelamente foi implantado o currículo nuclear, que implicou em um intenso processo de negociação e conflito, já que havia a necessidade de diminuir cargas horárias, redistribuir responsabilidades e integrar conteúdos. Mas foi nesse momento que os docentes se deram conta de que o movimento de mudanças era para valer e começaram a se interessar mais pelas discussões sobre currículo (entrevistado M3).

Foi criado um grupo ( 6 docentes do curso médico e 1 da enfermagem) que se submeteu a um processo de capacitação intensiva em ABP. Esse grupo, numa segunda fase, funcionou como multiplicador. Foram formados 8 novos grupos para desenvolvimento de sessões tutoriais, coordenados pelo grupo condutor (nesta altura já estavam envolvidos 47 docentes da medicina e 1 da enfermagem). 
Foi realizada então a oficina de trabalho para elaboração do projeto de implantação do ensino baseado em problemas na FAMEMA, que contou com a participação de 70 pessoas, entre docentes e estudantes.

Nesse processo, foi elaborada a nova proposta pedagógica e de organização curricular que pretendia ser implantada em 1997 e que

"representa o movimento concreto da academia em direção à institucionalização do ideário UNI, uma vez que compacta, integra e racionaliza informações básicas, incorporando um processo ativo de aprender a aprender $e$ buscando a articulação do conhecimento, comportamental e sócia, ale de propiciar a interação semanal, em todos os momentos do curso, com a comunidade" (PROJETO, 1996).

Paralelamente, como apoio à implementação do novo modelo de ensinoaprendizagem, havia atividades para o desenvolvimento de novas habilidades na academia. Eram parte dessas atividades os seguintes núcleos de trabalho: capacitação em informática, desenvolvimento da biblioteca, epidemiologia clínica, capacitação de lideranças estudantis, línguas e laboratório de simulação (PROJETO, 1996).

Além de realizar atividades junto ao corpo docente e de alunos, esses núcleos foram construindo as propostas de trabalho em cada uma dessas áreas e identificando os recursos necessários para a implementação do novo projeto.

Houve capacitação maciça de docentes, estudantes e funcionários em informática. A Biblioteca teve sua área física novamente ampliada e também foi equipada para atender as necessidades da nova proposta pedagógica. Foi criado o Laboratório de Simulação que passou a ser utilizado pelos alunos dos cursos de medicina, enfermagem e auxiliar de enfermagem.

Também o curso de enfermagem realizava atividades específicas de capacitação docente e de integração com os serviços de saúde e caminhava para uma reformulação curricular, que se consolidou um ano depois num currículo integrado baseado na metodologia da problematização. 


\subsubsection{Os espaços de poder}

Logo após a inclusão de Marília dentro do grupo UNI, houve uma ruptura entre a direção da faculdade e parte da equipe que coordenara a armação da proposta, havendo uma mudança na responsabilidade pela condução do projeto.

Ao longo do primeiro ano de implantação do UNI, o isolamento e o desgaste da direção da faculdade foram se acentuando de maneira importante. Como mencionado, ao final de 93, uma aliança, que reuniu todas as forças progressistas da faculdade, reconduziu o primeiro coordenador da proposta UNI à direção da FAMEMA (entrevistados M1, M4).

Ao longo do segundo ano de trabalho da nova gestão, ao mesmo tempo em que se começavam a se fazer visíveis os resultados do grande esforço para mobilizar os docentes e para encontrar saídas para a faculdade, disputas políticas ao interior do departamento de medicina preventiva fizeram com que a maior parte dos componentes desse departamento fossem para a oposição.

Apesar dessa defecção, o poder acumulado através da conquista da estadualização e da mobilização docente em torno das mudanças foi suficiente para garantir a necessária coesão para aprovar a proposta de mudança no Conselho Departamental e nas outras instâncias da faculdade.

Como havia a necessidade de reestruturação da FAMEMA para adaptar-se às exigências das normas estaduais, a direção da faculdade decidiu aproveitar o momento para radicalizar a transformação, apresentando a proposta de extinguir os departamentos e reorganizar os docentes em torno de Grupos Interdisciplinares de Trabalho. A proposta foi aprovada, mas gerou resistências importantes (entrevistado M1).

Com base em acusações de irresponsabilidade, falta de democracia e centralização, a oposição lançou uma chapa para as eleições que se realizaram imediatamente a seguir (final de 1996). A disputa foi dura, mas a direção foi reeleita, basicamente em razão de haver conquistado grande legitimidade entre os 
docentes e ampliado o espectro de forças na aliança que sustentava as mudanças (entrevistado M1).

Nos anos que se seguiram, o grupo da Medicina Preventiva manteve-se em oposição intensa e permanente. Assim sendo, o novo currículo foi construído com base em uma forte adesão dos professores da área básica e, posteriormente, da área clínica. Apesar de manter-se em confronto, o grupo de oposição foi se integrando às equipes de trabalho, mas manteve colaboração preferencial com o curso de enfermagem (entrevistados M1, M4 e M5).

A nova proposta político-pedagógica foi sendo implantada e ganhou legitimidade crescente dentro e fora da FAMEMA. A partir de 1999, a FAMEMA começou a ser reconhecida como referência no movimento nacional por mudanças na educação médica - o que, sem dúvida, reforçou o processo interno.

A partir do ano 2000, uma nova crise financeira da FAMEMA produziu uma prolongada situação de dificuldades e desgastes, que, no entanto, não chegaram a comprometer a implantação da nova proposta.

Nas eleições realizadas no início de 2001 houve nova disputa difícil, nova vitória do mesmo grupo. Outra vez com base no apoio maciço que lhes brindou o corpo docente. Foram conquistados, portanto, mais quatro anos para consolidar o processo de mudança.

\subsubsection{O trabalho em outros âmbitos}

Inicialmente muitos dos movimentos externos da FAMEMA foram no sentido de buscar idéias, experiências interessantes, referências que pudessem ser úteis. Depois surgiram as iniciativas com o objetivo de divulgar as experiências que iam sendo desenvolvidas.

Conforme foram sendo definidos mais claramente os objetivos estratégicos em termos da parceria e das mudanças acadêmicas, o UNI Marília foi intensificando sua exposição e a produção. Inicialmente eram principalmente 
folders, posters e outros materiais de divulgação; depois artigos e revistas (PROJETO, 1995).

O UNI Marilia esteve sempre presente nas articulações entre os projetos UNI brasileiros e tornou-se participante cada vez mais ativo da Rede IDA e depois da Rede UNIDA.

Presença constante e crescente nos encontros de educação médica paulistas e nacionais - foi sempre participante ativo dos fóruns e do processo de avaliação da CINAEM. Na terceira fase do projeto CINAEM dois docentes de Marília compuseram a equipe técnica ampliada que conduziu o trabalho. Também foi crescendo a participação em eventos internacionais de educação médica: Maastricht, Durban, México, Novo México etc (PROJETO, 1995), (PROJETO, 1996)

A FAMEMA e vários de seus docentes foram conquistando respeito e admiração no ambiente da educação médica em função de sua seriedade técnica, coerência, postura crítica e abertura.

Com o tempo, a FAMEMA conquistou o posto de referência nacional em relação às mudanças na formação dos profissionais de saúde e como um exemplo de parceria bem-sucedida entre academia e serviços, pois também o trabalho da secretaria de saúde ganhou destaque nacional (PROJETO, 2001).

Em 1999 um representante da FAMEMA ocupou pela primeira vez um posto na diretoria nacional da $A B E M$ e o secretário municipal de saúde foi eleito no ano 2000 o presidente do COSEMS-SP e em 2001 membro da diretoria do CONASEMS.

Atualmente o ex-diretor da FAMEMA e coordenador do projeto UNI assumiu a coordenação do PROMED (o programa de incentivo às mudanças curriculares nos cursos de medicina). 


\subsection{O novo curso}

A nova proposta foi chamada FAMEMA 2000. Inicialmente as definições sobre seu conteúdo eram bastante genéricas, como se pode observar nas formulações que serviram de base para a apresentação pública do Projeto FAMEMA 2000:

“A nova proposta institucionaliza as iniciativas promovidas pelo Projeto UNI Marilia, possibilitando e potencializando o desenvolvimento de um aluno ativo, crítico e partícipe na construção do conhecimento, com momentos semanais e contínuos de interação com os serviços de saúde e a comunidade, que serão desenvolvidos com complexidade crescente durante 0 curso de graduação" (LIMA et al, 1996).

"O novo currículo terá os alunos trabalhando em pequenos grupos, orientados por dois docentes, cujo papel será de facilitador do processo de ensino-aprendizagem" (...) "a diversificação dos recursos educacionais passa a ter um peso expressivo"..." a avaliação passa a ser sistemática, com caráter formativo, envolvendo grandes eixos como a aquisição de conhecimentos, atitudes, conduta ética e qualidades pessoais" (LIMA et al, 1996).

"Com base nas experiências desenvolvidas por docentes das $1^{a}, 4^{a}, 5^{a}$ e $6^{a}$ séries do curso médico e da $1^{a}$ a $4^{a}$ séries do curso de enfermagem junto às Unidades Básicas de Saúde e à comunidade, foi possível estruturar para o novo currículo atividades de interação semanal entre universidade, serviços e comunidade. Essas atividades envolvem docentes de 8 disciplinas do curso de medicina e 4 disciplinas do curso de enfermagem (ou sejam, envolvem a participação de 8 dos 10 departamentos que existem na FAMEMA) (LIMA et al, 1996). 
Nesse momento, previa-se, além das unidades longitudinais, representadas pela Interação Comunitária e de Habilidades - realizadas ao longo de todo ano ao longo das 4 primeiras séries - a existências das seguintes Unidades Educacionais:

Figura 24. Unidades educacionais do novo curso de medicina da FAMEMA em 1997.

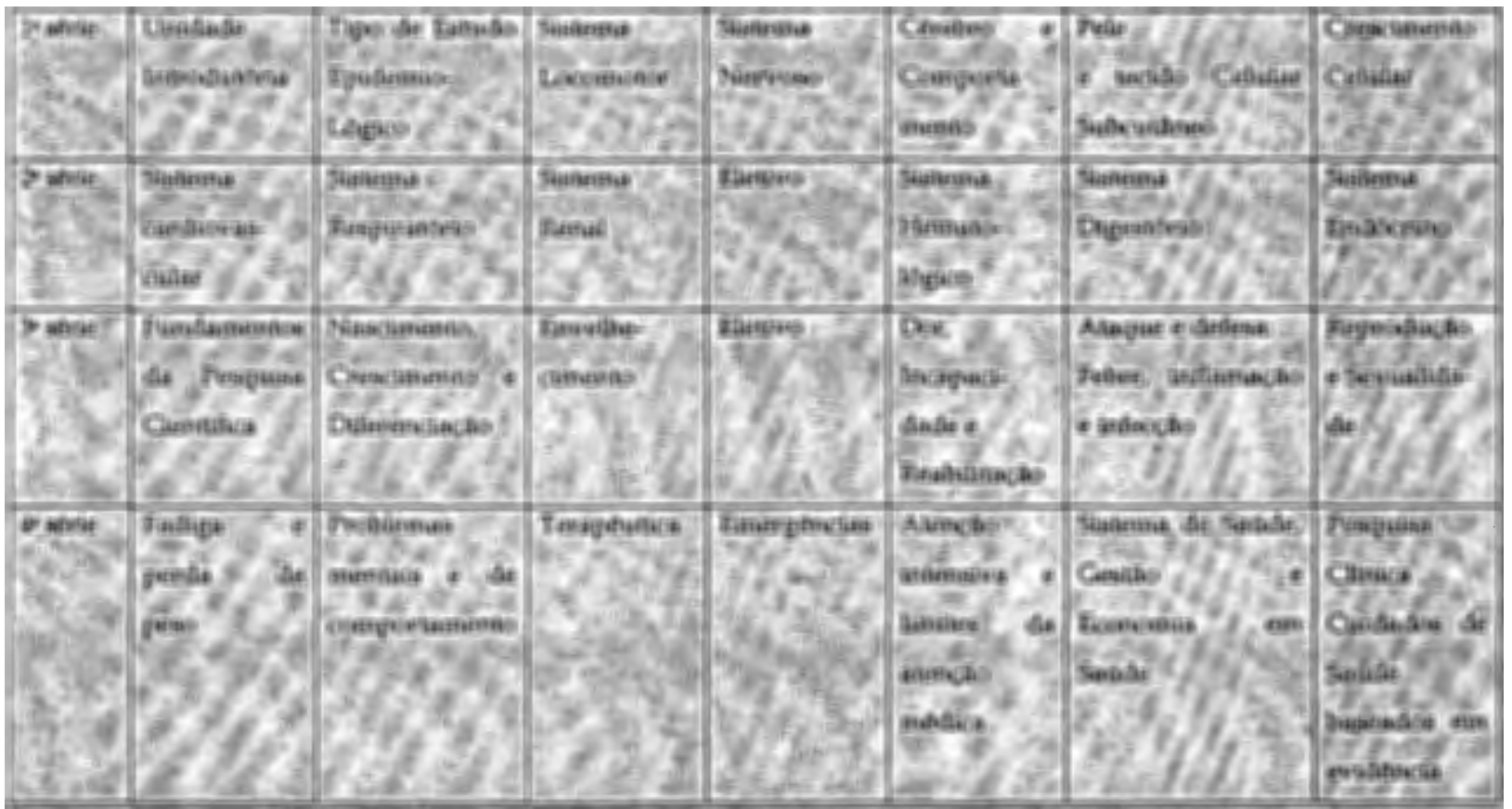

Fonte: LIMA et al, 1996

A próxima figura ilustra a semana padrão do primeiro ano de medicina, implantado a partir de 1997.

Figura 25. Semana Padrão do Curso de Medicina da FAMEMA em 1997.

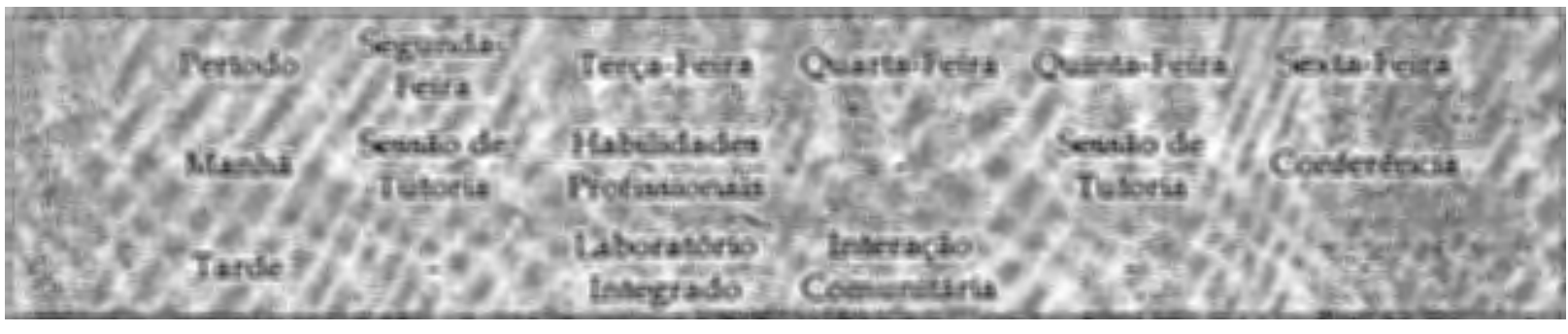

Fonte: Projeto FAMEMA 2000 (FACULDADE, 1997).

Já em 1997, quando iniciada a implantação do novo modelo, as definições a 
respeito da nova proposta estavam um pouco mais elaboradas. Definiam a nova proposta como um "Programa de Ensino-Aprendizagem Centrado no Estudante, Baseado em Problemas e Orientado à Comunidade". Ao longo dos primeiros 4 anos essa proposta se concretizaria através do trabalho sobre problemas organizados nas unidades educacionais integradas, das eletivas, de conferências e workshops, das atividades de Interação Comunitária e dos laboratórios interdisciplinares de ensino (FACULDADE, 1997).

No $5^{\circ}$ e $6^{\circ}$ anos, no internato, fundamentalmente ocorreria a "Aprendizagem Baseada na Prática", quando o paciente, na prática clínica, propõe o problema que leva o estudante a buscar e integrar conhecimentos; as atividades práticas sob supervisão ocorreriam na Comunidade, no Hospital Secundário e no Hospital Terciário. Também nessa etapa haveria eletivos, a serem realizados necessariamente em alguma das "grandes áreas" (clínica médica, cirurgia geral, gineco-obstetrícia, pediatria e saúde coletiva). Nesse caso, a existência dos eletivos teria como importantes objetivos a incorporação e o desenvolvimento efetivo do "currículo oculto". Estava prevista uma carga horária teórica mínima, concretizada através de trabalho em pequenos grupos, conferências, seminários, reuniões clínicas, que teriam como principal ênfase no Diagnóstico, Terapêutica e na Prática Baseada em Evidências (FACULDADE, 1997).

Definiam como centrais na nova proposta a interdisciplinaridade, a articulação teoria e prática e o estímulo à aprendizagem ativa, tanto através dos "problemas de papel", como da prática, como ilustra a próxima figura: 
Figura 26 . Integração básico-clínico e teoria-prática no novo currículo de medicina da FAMEMA em 1997.

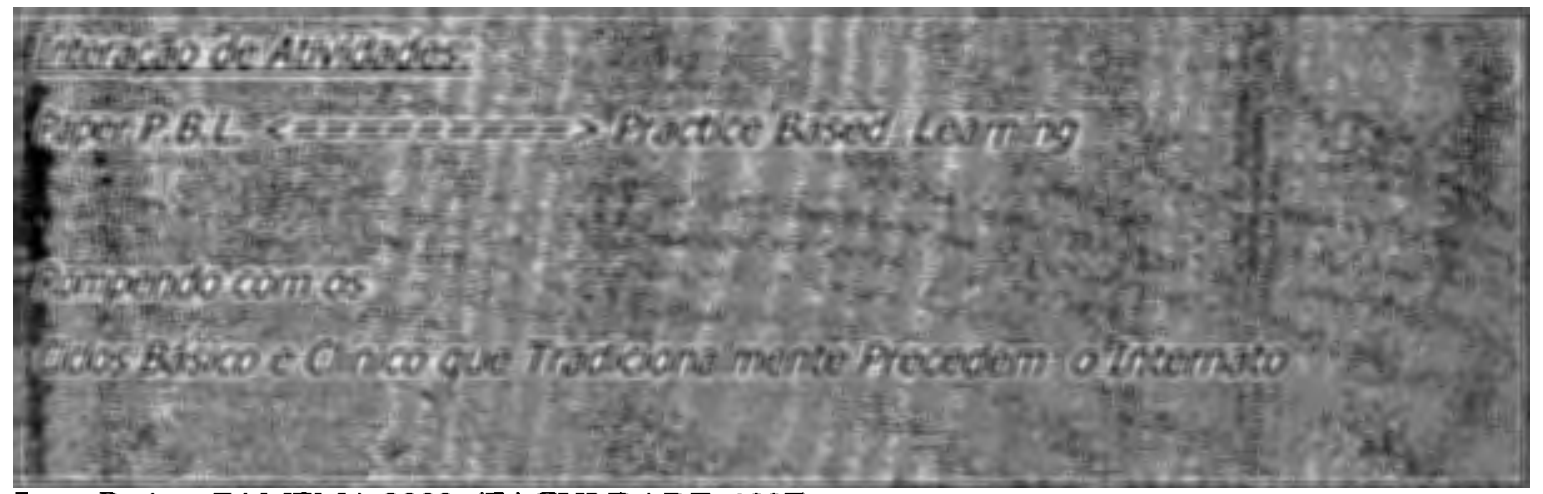

Fonte: Projeto FAMEMA 2000, (FACULDADE, 1997).

O processo de construção de conhecimento pelos estudantes estaria baseado em um "Salto Triplo", composto pelos seguintes elementos:

- "IDENTIFICAÇÃO DO PROBLEMA: possibilita ativar o conhecimento anterio; permite ao estudante estabelecer seus proprios objetivos e prioridades; favorece o intercâmbio de conhecimentos entre pessoas com diferentes experiências.

- BUSCA DA INFORMAÇÃO: promove o desenvolvimento de métodos de estudo pessoais e a descoberta; permite ao estudante selecionar e aprender a utilizar uma ampla variedade de recursos didáticos: pessoas, materiais audiovisuais, laboratórios, livros, revistas, softwares, etc.

- APLICAÇÃO DA EXPERIÊNCIA: possibilita a construção da síntese do conhecimento, bem como a avaliação crítica do produto obtido, além da construção de propostas para solução do problema"(FACULDADE, 1997).

A unidade de interação comunitária, desenvolvida em um período semanal ao longo dos primeiros anos dos cursos de medicina e enfermagem pretendia:

“... contribuir para formação de estudantes de Medicina e Enfermagem, de modo a desenvolver um olhar crítico, que permita ao aluno compreender a saúde enquanto processo. Para tanto, esses mesmos estudantes deverão desenvolver um conjunto de 
capacidades e habilidades, permeadas pelo compromisso ético, que lhes possibilite intervir, em equipe, nos problemas de saúde individuais e coletivos. Quer-se, enfim, que o conjunto dessas ações e intervenções tenha, sobretudo, uma orientação para e pela comunidade. (FACULDADE, 1997)

A figura 27 mostra como se pretendiam integrar conhecimentos e abordagens ao longo dos 4 anos da Interação Comunitária:

Figura 27 . As dimensões da Interação Comunitária na FAMEMA em 1997.

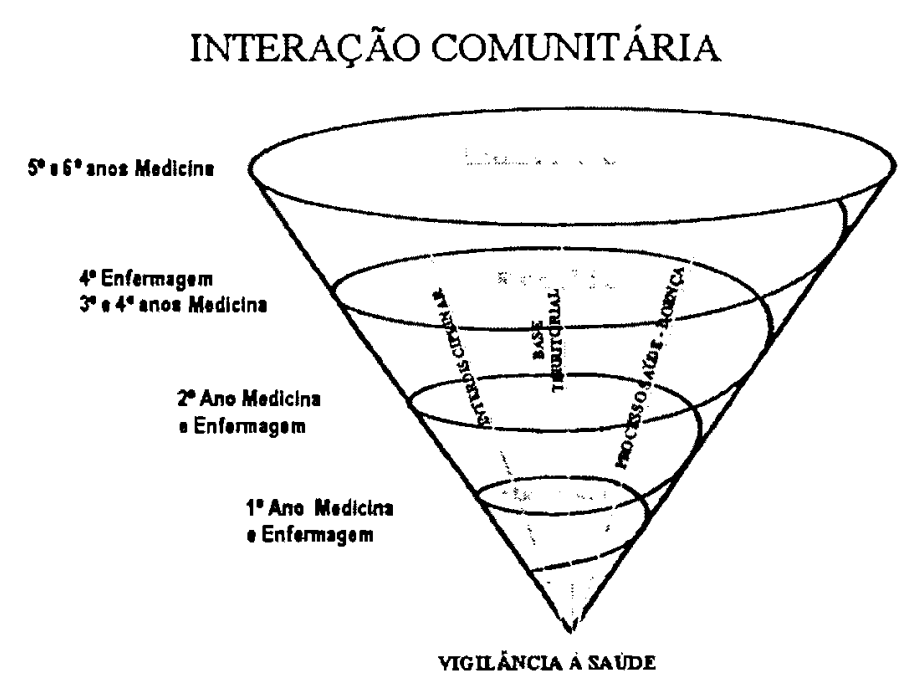

Fonte: Projeto FAMEMA 2000. (FACULDADE, 1997)

Propunham também a adoção da Avaliação Formativa Sistemática, "que implicaria a avaliação do conhecimento, da capacidade de crítica e de resolução de problemas, de atitudes, da conduta ética, das destrezas educacionais, das qualidades pessoais. Seriam utilizados os conceitos de Satisfatório, Satisfatório Condicional e Insatisfatório para qualificar desempenhos observados através de:

- Avaliação em tutoria: contínua, auto-avaliação ao final de cada sessão

- Análise das necessidades pessoais de cada estudante

- Exercicios escritos" (FACULDADE, 1997). 


\subsubsection{O projeto político-pedagógico}

Os problemas $\mathrm{e}$ as necessidades da comunidade deveriam nortear $\mathrm{o}$ estabelecimento dos objetivos educacionais e de aprendizagem. $\mathrm{O}$ objetivo principal do curso médico seria prover aos estudantes uma qualificação profissional, buscando capacitar os estudantes para:

- "o processo contínuo de aprender a aprender;

- prestar atenção aos pacientes;

- desenvolver o entendimento da saúde individual inserida em um contexto sócioeconômico de uma determinada população;

- desenvolver as habilidades técnicas efetivas para o gerenciamento dos problemas de saúde dos pacientes e da população;

- adotar comportamento profissional ético e humanistico;

- desenvolver a capacidade de trabalhar em equipe e atuar para a melhoria de saúde da população;

- desenvolver prática baseada em evidências" (KOMATSU et al, 1997a).

Os quatro princípios centrais que orientavam a proposta eram a aprendizagem auto-dirigida, a aprendizagem baseada em problemas, a aprendizagem em pequenos grupos e a aprendizagem orientada à comunidade.

\section{Aprendizagem Auto-dirigida}

De acordo com a nova proposta, o estudante deveria preliminarmente compreender que "a aprendizagem auto-dirigida não é sinônimo de aprendizagem autoindulgente." (RAMSDALE, 1996) e conhecer os primeiros passos do caminho para aprender a aprender. 
Como busca e aquisição de conhecimentos são processos contínuos, que persistem ao longo da vida de cada indivíduo, pretendia-se que "os estudantes durante o Curso de Medicina sejam encorajados a definir seus próprios objetivos de aprendizageme tomar a responsabilidade por avaliar seus progressos pessoais em relação a quanto estão se aproximando dos objetivos formulados" (FACULDADE,1997).

Esta avaliação deveria incluir "a habilidade de reconhecer necessidades educacionais pessoais, desenvolver um método próprio de estudo, utilizar adequadamente uma diversidade de recursos educacionais e avaliar criticamente os progressos obtidos" (KOMATSU et al, 1997a).

Cada estudante deveria considerar cada opção existente para a aprendizagem autodirigida e "identificar quais atitudes estão mais adequadas ao seu próprio estilo. Deveria, então, discutir suas características pessoais de aprendizagem com seu tutor e/ou orientador" (KOMATSU et al, 1997a).

\section{Aprendizagem Baseada em Problemas}

Parte-se do pressuposto de que o significado da aprendizagem aumenta quando o estudante consegue aplicar o conhecimento em seu cotidiano ou quando ele reconhece, em sua vida e em suas atividades, situações semelhantes às estudadas. Na nova proposta, o problema - uma situação ou questão de atenção à saúde - seria utilizado como estímulo à aquisição de conhecimento e compreensão de conceitos e também para o desenvolvimento de raciocínio clínico, de habilidades e atitudes (KOMATSU et al, 1999). Nenhuma exposição formal prévia de informação seria oferecida e era recomendada a seguinte seqüência de passos:

1. "Aclarar o problema oferecido, explorando-o e refletindo se existe alguma pergunta sobre a descrição do problema que possa ser formulada.

2. Resumo dos dados oferecidos no problema, especificando: o que é o problema? do que trata o problema?

3. Identificação de áreas/pontos importantes ao problema, através da definição de quais são as áreas relevantes de conhecimento dentro das três dimensões: , biológica, 
psicológica e populacional, considerando os objetivos de aprendizagem em cada unidade educacional.

4. Identificação do conhecimento atual relevante para o problema, através da busca dos conhecimentos relevantes frente aos objetivos de aprendizagem propostos.

5. Desenvolvimento de hipóteses, a partir da explicação os dados apresentados no problema.

6. Identificação do conhecimento adicional requerido para melhorar a compreensão do problema, baseado nas necessidades de aprendizagem individual e/ou do grupo.

7. Identificação dos recursos de aprendizagem apropriados, dentre uma diversidade: livros, periódicos (revistas), bases locais de dados (Medline, Lilacs) ou remotas (Internet, BIREME), programas interativos multimidia, entrevistas com professores, profissionais ou usuários, vídeos, slides, laboratórios, serviços de saúde, comunidade; isto é, quais são as fontes de recursos mais apropriadas à exploração deste problema?

8. Procura de novos conhecimentos, utilizando recursos de aprendizagem apropriados, o que implica em ampliar os horizontes de busca além dos limites institucionais (outras bibliotecas, outros acervos, outros locais passiveis de utilização no processo ativo de ensino-aprendizagem).

9. Sintese de conhecimentos prévios e novos em relação ao problema; isto é, baseado em sólidas evidências científicas, como se pode explicar o problema agora?

10. Repetição de alguns ou todos os passos anteriores, se for necessário.

11. Reconhecimento do que foi identificado como uma necessidade de aprendizagem, mas que não foi adequadamente explorada, para incursões complementares.

12. Sintese dos conhecimentos auferidos, e se possivel, testar a compreensão do conhecimento adquirido por sua aplicação em outra situação ou problema" (KOMATSU et al, 1997a). 
Aprendizagem Baseada em Pequenos Grupos

A Aprendizagem Baseada em Problemas pode ocorrer tanto de maneira individual como em pequenos grupos, porém, segundo a nova proposta,

"é no grupo de tutoria que o pensamento crítico pode ser encorajado, pois aí argumentos levantados, idéias podem ser construidas de maneira criativa, novos caminhos podem ser estabelecidos, permitindo a análise coletiva de problemas que espelhem a prática profissional futura" (KOMATSU et al, 1997a).

O estudante deveria "desenvolver competências para tornar-se um ativo integrante com contribuições para o grupo, seja este um grupo de aprendizagem, de pesquisa ou de trabalho, formado por profissionais" (KOMATSU et al, 1997a).

Orupo de tutoria representaria, portanto, um laboratório para aprendizagem sobre a interação e integração humana, em que estudantes poderiam

“desenvolver habilidades de comunicação e relacionamento interpessoal e a consciência de suas próprias reações no trabalho coletivo, constituindo uma oportunidade para aprender a ouvir, a receber e assimilar críticas, e por sua vez, oferecer análises e contribuições produtivas ao grupo" (KOMATSU et al, 1997a).

O tutorial seria um fórum em que os recursos dos membros do grupo são mais efetivos que a somatória das atividades individuais e que promoveria a oportunidade para a autoavaliação, através da qual o estudante poderia comparar informalmente seu progresso com o de seus parceiros.

\section{Aprendizagem Orientada à Comunidade}

Segundo a nova proposta, existia um amplo acordo internacional a respeito da necessidade de diversificar os cenários de ensino-aprendizagem de modo a oferecer aos estudantes oportunidades para desenvolver conhecimentos, 
habilidades e atitudes compativeis com as exigências dos tempos atuais. Um programa de ensino-aprendizagem orientado à comunidade seria uma das possibilidades fortemente consideradas para concretizar essa mudança. A orientação à comunidade "consistiria em proporcionar atividades de ensino-aprendizagem que utilizam extensivamente a comunidade como ambiente de aprendizagem", possibilitando o conhecimento da realidade e o trabalho multiprofissional, já que

“atualmente não é mais possivel um médico se responsabilizar sozinho pela saúde do indivíduo e da comunidade, pois essa responsabilidade deve ser assumida conjuntamente com os pacientes, com outros profissionais de saúde e com a familia" (FACULDADE, 1997).

A Interação Comunitária, uma unidade desenvolvida semanal e continuamente em todas as séries do currículo de graduação, seria parte fundamental dessa proposta educacional baseada na comunidade, com trabalho em equipe multiprofissional e interdisciplinar. Nessa unidade participariam estudantes dos cursos de Enfermagem e Medicina com atividades conjuntas.

Pretendiam que a Interação Comunitária possibilitasse ao estudante "trabalhar com membros da comunidade, não se restringindo à temática médica estrita, mas abordando outros setores afins aos problemas de saúde existentes ou potenciais" (FACULDADE, 1997).

Os estudantes, organizados em equipes, realizariam pesquisas na comunidade e várias outras ações que permitissem a eles "adquirir experiências em vigilância à saúde e em análise e solução de problemas, bem como habilidades clínicas relacionadas aos cuidados de saúde da comunidade, possibilitando que no futuro sejam participantes ativos de programas de base comunitária" (FACULDADE, 1997)

\subsubsection{A concepção de currículo}

Segundo a nova proposta, a relevância de um programa de ensinoaprendizagem define-se pela orientação da prática profissional às necessidades dos 
pacientes, seus familiares e da comunidade. São os problemas existentes nestes diferentes contextos que devem servir de orientação para a definição dos objetivos e conteúdos do programa, bem como as propostas de intervenção a serem construídas em parceria com os serviços de saúde e a comunidade. Os problemas permitiriam a abordagem integrada do conteúdo de várias disciplinas e possibilitariam a articulação das dimensões biológica, psicológica e social (KOMATSU et al, 1999).

Cada unidade educacional deveria ter seus objetivos específicos definidos de maneira articulada com os objetivos terminais do curso. Uma equipe de docentes, oriundos das várias disciplinas que podem contribuir para o desenvolvimento do tema em foco, ficaria responsável pela elaboração dos objetivos, dos conteúdos, dos problemas e pela definição dos principais recursos educacionais necessários para a aprendizagem (PROJETO, 1998).

Propunham também que o currículo propiciasse aos estudantes a organização do conhecimento através da exploração de cada situação ou problema em torno de três perspectivas, que consideravam indissociáveis na formação dos profissionais de saúde: a biológica, a psicológica e a populacional. Para que se atingissem os objetivos educacionais, cada uma dessas perspectivas implicaria na articulação da contribuição de diversas disciplinas e campos de conhecimento (KOMATSU et al, 1997a).

No plano biológico são mencionadas explicitamente: anatomia humana, biologia celular, histologia, embriologia, genética e evolução, fisiologia, biologia molecular, bioquímica, farmacologia, patologia, parasitologia, microbiologia, imunologia, nutrição, clínica médica, cirurgia, ginecologia, obstetrícia e pediatria (KOMATSU et al, 1997a).

No plano psicológico, são apontadas as ciências comportamentais, como a psicologia, a psiquiatria, sociologia, antropologia, filosofia e ética. Neste caso são identificados os elementos considerados de contribuição fundamentais dessa área: a dinâmica da comunicação interpessoal, o poder da relação médico-paciente, as 
questões éticas na tomada de decisões, o respeito à autonomia do paciente, o segredo médico e o impacto da doença no estilo de vida do paciente e na dinâmica familiar (KOMATSU et al, 1997a).

No assim chamado plano populacional, são mencionadas: epidemiologia, epidemiologia clínica, bioestatística, saúde coletiva, economia em saúde, sociologia, antropologia, direitos difusos e legislação e bioética. Foram destacadas as seguintes habilidades a serem desenvolvidas nesse campo: identificação dos fatores subjacentes à saúde de uma pessoa ou população, aprender trabalhar em equipe em prol das condições do paciente, aprender a intervir precocemente na cadeia causal das doenças, conhecer como funciona e se articula a rede de serviços disponíveis, aprender a defender interesses e ideais de pacientes e populações, aprender a encontrar soluções na comunidade e não somente dentro do consultório (KOMATSU et al, 1997a).

Consideravam que o desenvolvimento curricular deveria ser permanente e para tanto a avaliação constante do programa e a existência de espaços de debate e reflexão crítica sobre cada unidade educacional seriam fundamentais. Desse modo, não haveria necessidade de que esse desenvolvimento ocorresse "aos saltos, somente através de reformas curriculares", pois o aperfeiçoamento iria sendo feito ao longo do tempo, em processo (KOMATSU et al, 1998).

A capacitação docente também foi identificada como uma estratégia importante para que o aperfeiçoamento da proposta fosse contínuo. A nova proposta político-pedagógica implicaria novas funções e papéis para os docentes, muito diferentes das tradicionais, e pretendia-se usar a capacitação como estratégia para possibilitar "essa mudança cultural". Foram criadas oficinas de capacitação para cada uma das novas funções - tutoria, orientação de estudantes, consultoria e incentivada a qualificação mais ampla dos docentes na área da educação de profissionais de saúde através de programas de pós-graduação em instituições internacionais (Dundee, Maastricht, Chicago) e nacionais (UNESP) (KOMATSU et al, 1998). 
A flexibilidade curricular era considerada fundamental para que se pudesse atender ao princípio de o currículo ser "centrado nas necessidades do aluno" e as disciplinas eletivas são parte importante dessa flexibilidade.

"São estágios de livre escolha de cada estudante, com duração de 6 semanas do $2^{\circ}$ ao $4^{\circ}$ ano do curso. $O$ único requisito é que respondam aos interesses comuns entre estudante e programa (materializado nas figuras do coordenador de série e do coordenador do curso). O objetivo é possibilitar ao estudante personalizar sua capacitação, aliando oportunidade e interesse" (KOMATSU et al, 1998).

\subsubsection{Os cenários de aprendizagem e os conteúdos das práticas}

São chamados de recursos de aprendizagem e aí estão incluídos todos os ambientes que propiciam aos estudantes $o$ acesso às informações relevantes para seu processo de aprendizagem, especialmente a auto-aprendizagem.

Consideram que inexiste aprendizagem sem a prática e sem a realidade: os problemas de papel, portanto, podem antecipar, desafiar e motivar para a prática e a realidade. Portanto é fundamental que a aprendizagem baseada em problemas esteja integrada e complementada com a aprendizagem baseada na prática, procurando atingir uma aprendizagem baseada na realidade.

O espaço de interação ensino-serviço-comunidade e o contato e relação interpessoal com colegas, tutores, consultores, orientadores, profissionais de saúde, técnicos e pacientes são considerados como os grandes ambientes de aprendizagem oferecidos aos estudantes desde o primeiro dia e ao longo de todo o curso. Através das relações e interações com pessoas e com a comunidade que esses dois ambientes propiciam, pretendia-se conferir amplitude, humanidade e realidade ao processo de ensino-aprendizagem, tornando-o muito mais rico e dinâmico (KOMATSU et al, 1998).

Os espaços de integração entre ensino-serviço-comunidade, considerados fundamentais para a aprendizagem, incluiriam: as casas das pessoas, espaços 
comunitários, escolas, creches, unidades básicas de saúde, unidades de saúde da família, ambulatórios de especialidades, enfermarias e pronto-socorros.

Além desses, são considerados também espaços fundamentais, preparados intensamente no período que antecedeu a mudança e atualizados ao longo de sua implantação, a Biblioteca e os Laboratórios de Aprendizagem (Informática, Morfofuncional e Habilidades Clínicas) (KOMATSU et al, 1998).

A Biblioteca havia sido ampliada e equipada para poder oferecer aos estudantes a possibilidade de consulta intensiva a todos os materiais considerados relevantes para seu processo de aprendizagem: tanto os fisicamente presentes no acervo, como os disponíveis a distância através da Internet (KOMATSU et al, 1998).

Ferramenta fundamental para a busca de informações à distância, o acesso e treinamento no campo da informática haviam sido trabalhados anteriormente $\mathrm{e}$ seriam recursos oferecidos amplamente aos estudantes em seu processo de formação.

Os Laboratórios de Aprendizagem ofereceriam aos estudantes ambientes integrados e dinâmicos, que reuniriam elementos fundamentais para atividades didáticas e também para a auto-aprendizagem: peças, lâminas, simuladores, bonecos, filmes, aparelhos de ultrassonografia, salas para exame físico e para procedimentos básicos de patologia clínica etc (KOMATSU et al, 1998).

Para o internato (duas últimas séries do curso) estavam previstas atividades na esfera da atenção primária (na $5^{\mathrm{a}}$. série) - o chamado externato - e também atividades nas grandes áreas clínicas e em urgência/emergência em âmbito hospitalar.

A Unidade de Interação Comunitária consistiria em um dos elementos fundamentais para definição do conteúdo das práticas desenvolvidas ao longo de todo o curso. Pretendia-se que através desse trabalho contínuo fosse possível proporcionar aos estudantes os conhecimentos, habilidades e práticas necessárias ao trabalho em atenção primária à saúde (KOMATSU et al, 1997a). 
O programa de habilidades envolveria não somente as habilidades clínicas, mas também as habilidades de aprendizagem e de raciocínio crítico.

As habilidades clínicas envolveriam tanto as habilidades de comunicação como as de exame físico, de realização de procedimentos específicos, de formulação de hipóteses e de raciocínio clínico. Seriam fundamentais para capacitar o estudante a adquirir, sintetizar, interpretar e registrar informações clínicas. As principais habilidades a serem desenvolvidas seriam: comunicação médico / paciente / cuidador / família, coleta de dados clínicos, geração de hipóteses, tomada de decisões clínicas e comunicação interprofissional. Cada unidade educacional estabeleceria um programa de atividades para a aquisição das habilidades correspondentes (KOMATSU et al, 1997a).

As habilidades de raciocínio crítico envolveriam o desenvolvimento de capacidades para abordagem crítica e questionadora das informações e dos estudos - definição clara de um problema e de estratégias para conhecê-lo; desenvolver várias estratégias de pesquisa de informações; avaliar dados e informaçōes, sendo capaz de compreender metodologia e análise estatística; avaliação crítica das evidências.

As oportunidades para o desenvolvimento dessas habilidades ocorreriam durante o trabalho com os problemas nas sessões tutoriais e no contato com os pacientes (KOMATSU et al, 1997a).

As habilidades de aprendizagem seriam fundamentais para que o estudante pudesse aprender a aprender, um dos objetivos centrais da nova proposta. Algumas dessas habilidades seriam: fazer perguntas apropriadas; ser capaz de estabelecer objetivos de aprendizagem apropriados; estabelecer prioridades; organizar o tempo; utilizar vários recursos e selecionar material de aprendizagem apropriado; conhecer onde e quando aprender melhor; ser capaz de organizar e processar as informações; ser capaz de apresentar essas informações de maneira clara e organizada. Essas habilidades seriam desenvolvidas tanto nos tutoriais como nas atividades de habilidades clínicas (KOMATSU et al, 1997a). 
Em relação ao comportamento profissional, buscava-se o desenvolvimento de atitudes adequadas. Considerado também fundamental, seria estabelecido como uma das áreas de avaliação do processo de ensino-aprendizagem, envolvendo: respeito, responsabilidade, comunicação e capacidade de autoavaliação.

Essas temáticas seriam abordadas ao longo de todo o curso, sendo espaços privilegiados para o seu desenvolvimento as sessões de tutoria e as oportunidades de atendimento a pacientes ao longo de todas as séries. Os estudantes seriam estimulados a perceber como seu comportamento provoca impacto nas outras pessoas e como a avaliação dessas situações pode ajudar na construção de um comportamento profissional adequado (KOMATSU et al, 1997a).

\subsubsection{A avaliação}

Considerada atividade fundamental para a mudança proposta. Foi, então, conformada uma equipe de avaliação com 8 docentes do curso de medicina, 4 do curso de enfermagem, uma psicóloga do núcleo de apoio ao discente e um estudante representante de cada curso (medicina e enfermagem). A coordenação dessa equipe e outros 3 docentes também participavam da equipe de avaliação do projeto UNI (PROJETO, 1998).

Previa-se que a comissão se reunisse semanalmente para planejamento e análise da avaliação do estudante, do tutor-docente, das atividades educacionais, dos recursos educacionais e também da avaliação curricular. A maior responsabilidade do grupo seria a análise dos processos de implementação dos novos currículos e do ensino-aprendizagem.

Em relação à avaliação somativa, a atuação da equipe seria de caráter consultivo e de orientação aos coordenadores das unidades, das séries e dos cursos (PROJETO, 1998). 


\subsubsection{A avaliação do estudante}

O sistema proposto levava em conta alguns princípios:

- a competência deveria ser medida de acordo com os objetivos de aprendizagem para cada unidade e para cada série, que deveriam ser compatíveis com os objetivos gerais do programa como um todo. Além disso, os alunos deveriam ser fortemente estimulados a estabelecer objetivos individuais, baseados em suas próprias necessidades e interesses. Previa-se também que

“o alcance dos objetivos deveria ser avaliado em comparação com um perfil minimo esperado. A avaliação do alcance dos objetivos também seria importante para auxiliar os estudantes no uso dos recursos educacionais disponiveis segundo suas caracteristicas, necessidades e aspirações" (KOMATSU et al, 1997a).

- os métodos de avaliação deveriam ser compatíveis com os objetivos de aprendizagem, portanto

"os métodos avaliativos deveriam ser concebidos de acordo com a concepção da aprendizagem baseada em problemas e na resolução de problemas, o que implica a integração de conceitos de diversas disciplinas, de acordo com os objetivos do curso" (KOMATSU et al, 1997a)

- as informações para a avaliação deveriam ser provenientes de várias fontes. Seriam consideradas fontes:

"o tutor, o próprio estudante, seus colegas de grupo, outros membros da faculdade e os pacientes, pois cada um deles contribui com diferentes pontos de vista sobre uma mesma experiência e sobre várias experiências. Há uma definição mínima de fontes que deverão ser usadas em todas as unidades $e$ que incluem a observação das sessões de tutoria e o exercicio de avaliação baseado em problemas. As demais fontes serão acrescidas de acordo com a pertinência em relação aos objetivos educacionais das unidades" (KOMATSU et al, 1997a). 
Destacava-se como fundamental que "o estudante conhecesse todas as informações nas quais estará baseada sua avaliação e que fosse permitido a ele comentá-las" (KOMATSU et al, 1997a).

- a avaliação deveria ser contínua, portanto, além da avaliação do produto final (quando se mede em que grau foram alcançados os objetivos), também seria fundamental avaliar o processo, ou seja o desenvolvimento do binômio ensinoaprendizagem.

Para tanto, "o trabalho dos estudantes nos grupos de tutoria deveria ser continuamente avaliado e registrado em um documento sintese na metade e ao final de cada unidade" (KOMATSU et al, 1997a).

A avaliação seria consolidada em um resumo final e todo o processo deveria ser apresentado e discutido com o estudante.

Como já mencionado, haviam sido propostos três critérios de progressão: satisfatório, satisfatório condicional e insatisfatório. O estudante que obtivesse uma avaliação satisfatória condicional ou insatisfatória seria " avaliado por uma comissão formada pelo professor responsável pela unidade, pelo professor orientador, o tutor e o próprio aluno para uma análise das dificuldades e delineamento das estratégias de superação" (KOMATSU et al, 1997a).

Ao final da unidade subseqüente, o aluno que recebesse qualificação satisfatória condicional teria uma segunda oportunidade para melhorar seu desempenho em relação ao conteúdo da unidade anterior. $O$ aluno que recebesse qualificação insatisfatória em uma unidade teria oportunidade de repeti-la para reposição de atividades, como parte de um plano prioritariamente de autoaprendizagem. Duas qualificações insatisfatórias implicariam reprovação na série (KOMATSU et al, 1997a). 


\subsubsection{A avaliação do programa}

Pretendia-se que fosse feita continuamente e que estivesse a cargo da Equipe de Avaliação. Para tanto foram criados formatos para avaliação do desempenho do tutor, das unidades educacionais e dos recursos educacionais utilizados em cada unidade.

Os instrumentos para avaliação das unidades eram quantitativos e qualitativos e pretendiam avaliar os objetivos educacionais, os problemas, a organização da unidade e a consultoria. Também foi previsto o mesmo processo para avaliação da Interação Comunitária. Os recursos educacionais seriam avaliados através de formatos basicamente quantitativos.

Pretendia-se oferecer um feed-back contínuo aos responsáveis ao final de cada etapa de trabalho.

\subsubsection{Os instrumentos de avaliação}

Inicialmente estavam previstos os seguintes instrumentos e documentos:

\section{Avaliação do estudante:}

- Formato 1 - resultado final da avaliação

- Formato 2 - Consolidação das diversas fontes de avaliação

- Formato 3 - Avaliação da perfomance do estudante nas sessões de tutoria

- Exercício de avaliação baseada em problema (EABP)

- Teste de Múltipla escolha e/ ou Prova Escrita (TME/PE)

- Prova Prática (P.P.)

\section{Avaliação do tutor}

- Formato 6 - Avaliação da performance do tutor 


\section{Avaliação dos recursos educacionais}

- Formato 7 - Avaliação do LEP - Laboratório Morfo-funcional

- Formato 8 - Avaliação do Laboratório de Informática

- Formato 9 - Avaliação da Biblioteca

\section{Avaliação das unidades}

- Formato 10

O cronograma de avaliação do estudante seria o seguinte:

Figura 28. Cronograma das atividades de avaliação no curso de medicina da FAMEMA em 1997.

\begin{tabular}{|l|c|c|c|}
\hline & $\begin{array}{l}\text { Metade da unidade } \\
\text { Todos os estudantes }\end{array}$ & $\begin{array}{l}\text { Final da unidade } \\
\text { Todos os estudantes }\end{array}$ & $\begin{array}{l}\text { Final da unidade } \\
\text { subsequiente } \\
\text { Estudantes com } \\
\text { satisfatório } \\
\text { condicional }\end{array}$ \\
\hline Formato 1 & - & $\mathrm{x}$ & $\mathrm{x}$ \\
\hline Formato 2 & - & $\mathrm{x}$ & $\mathrm{x}$ \\
\hline Formato 3 & $\mathrm{x}$ & $\mathrm{x}$ & - \\
\hline EABP & - & $\mathrm{x}$ & $\mathrm{x}$ \\
\hline TME/PE $(\mathrm{S} / \mathrm{N})$ & - & $\mathrm{x}$ & $\mathrm{x}$ \\
\hline PP (S/N) & - & $\mathrm{x}$ & $\mathrm{x}$ \\
\hline
\end{tabular}

Fonte: Guia do Processo de Ensino-Aprendizagem da FAMEMA (KOMATSU et al,1997a).

$\mathrm{S} / \mathrm{N}$ - se necessário

As unidades, bem como os recursos educacionais utilizados em cada uma delas, seriam avaliadas por professores e estudantes, imediatamente após o seu término.

\subsubsection{A gestão do processo de mudança}

Como comentado, aproveitou-se a oportunidade da estadualização para realizar uma ampla reforma administrativa que levasse à existência de estruturas 
de gestão coerentes com a nova proposta político-pedagógica adotada pela instituição.

De acordo com os novos estatutos pós-estadualização, o Diretor-Geral da FAMEMA era responsável pela administração geral, acadêmica e financeira da instituição.

Os orgãos diretivos da instituição eram a Congregação e as Câmaras (como a de Graduação, por exemplo), compostos por representantes do corpo docente, discente e da área técnico-administrativa (KOMATSU et al, 1997a).

Os departamentos seriam substituídos por Grupos Interdisciplinares de trabalho, que estariam responsáveis pela organização e operacionalização das atividades didáticas, científicas e de atenção à saúde.

A coordenação geral dos dois cursos - medicina e enfermagem - era feita pela Diretoria de Graduação, assessorada pelo Grupo Interdisciplinar de Trabalho de Educação em Ciências da Saúde e pelas equipes de Avaliação, Desenvolvimento Curricular do Curso Médico, Desenvolvimento Curricular do Curso de Enfermagem, Treinamento e Capacitação de Tutores, Interação Comunitária, Professores Responsáveis pelas Unidades Educacionais (KOMATSU et al, 1997a).

Cada série contaria com um coordenador e as unidades seriam construídas por grupos conformados por um docente responsável e grupos interdisciplinares de trabalho. Como áreas de apoio, estariam a Biblioteca e os vários Laboratórios (KOMATSU et al, 1997a).

O novo regulamento da instituição incluiu todas as mudanças necessárias à implantação do novo currículo: definição dos papéis e do trabalho docente, sistema de avaliação baseado em critérios como satisfatório e insatisfatório e não em notas etc.

\subsection{O que aconteceu na prática}

A implantação da nova proposta pedagógica e curricular implicou um grande esforço de mobilização. O nível necessário de apropriação, em termos 
conceituais e metodológicos, para construir e implantar a nova proposta foi sendo atingido na prática.

Existia clara consciência acerca das limitações que enfrentavam em termos de consistência conceitual e de experiências acumuladas. O grupo coordenador do processo investiu profundamente em capacitação (na sua própria - estavam organizados em grupos de estudos - e na dos demais docentes). Além disso, desde sempre foi buscada ajuda conceitual e prática - através de consultorias, algumas pontuais e outras permanentes.

Desde o último semestre de 96, o trabalho de construção das unidades, dos problemas e de capacitação de tutores estava sendo feito com estreita colaboração de dois consultores da MacMaster University. Um desses professores foi depois contratado (com suporte do programa de apoio do UNI e dos projetos de Londrina e Botucatu) para um ano de trabalho presencial no Brasil (principalmente em Marilia, mas também em Londrina e, em menor grau, em Botucatu), durante seu ano sabático. Mais adiante, a colaboração desse professor foi importante no desenvolvimento do trabalho de habilidades e de capacitação docente (PROJETO, 1998).

Também o Núcleo de Tecnologia Educacional para a Saúde, da Universidade Federal do Rio de Janeiro, foi chamado a dar sua colaboração permanente, assessorando outros aspectos da construção das unidades e da articulação entre trabalho e formação (PROJETO, 1998).

Foram também buscadas outras ferramentas consideradas essenciais para a gestão do processo: imersão no planejamento estratégico através de um curso intensivo com Carlos Matus, ao final do qual saíram com um plano de ação para a implantação da nova proposta em seus vários aspectos. De acordo com o entrevistado M1, não importou muito se o plano elaborado nesse momento terminou sendo seguido ou não: o mais importante foi que aprenderam a identificar as variáveis que influíam no processo e a desenvolver estratégias para enfrentá-las de maneira organizada e antecipada. 
No primeiro ano de implantação, todo o grupo gestor se envolveu diretamente na construção prática dos trabalhos. "Os tutores do primeiro ano tinham um compromisso impressionante. Eles abraçaram a causa quase como religião; era como se fosse uma questão de vida e morte. A avaliação dos estudantes em relação a eles é impressionante" (entrevistado M5).

O curso foi crescendo; os professores, no início majoritariamente das disciplinas básicas, foram se envolvendo. Os dois principais mecanismos de inclusão na nova proposta, em um primeiro momento, foram a tutoria e a participação na construção das unidades. Aliás, o desenho das unidades, por sistema, havia sido uma opção feita para facilitar a participação e a adesão dos docentes, que desse modo "conseguiam enxergar qual era seu lugar nesse novo currículo" (entrevistados M1, M2, M3).

Cada tema era debatido com muito entusiasmo e seriedade conceitual: aprendizado ou aprendizagem, tutoria com tempo estabelecido ou livre, eletivos com opções fechadas ou totalmente abertos e negociados, indicação bibliográfica ou não, critérios de progressão etc.

Havia um acompanhamento muito próximo, tanto em termos da avaliação das unidades e dos tutores, como através de reuniões periódicas e freqüentes com os estudantes (entrevistados M3 e M5). "Era como se fosse um bebê, muito cuidado" (entrevistado M5).

Logo no primeiro ano de implantação, quando tiveram uma noção mais clara a respeito da distribuição dos conteúdos, foi feita a primeira mudança na estrutura curricular: as unidades da quarta série passaram a ser concebidas como de "Apresentações Clínicas", várias unidades tiveram seu lugar trocado e a grade curricular ficou assim redefinida: 
Figura 29. Grade Curricular Curso de Medicina da FAMEMA em 1998.

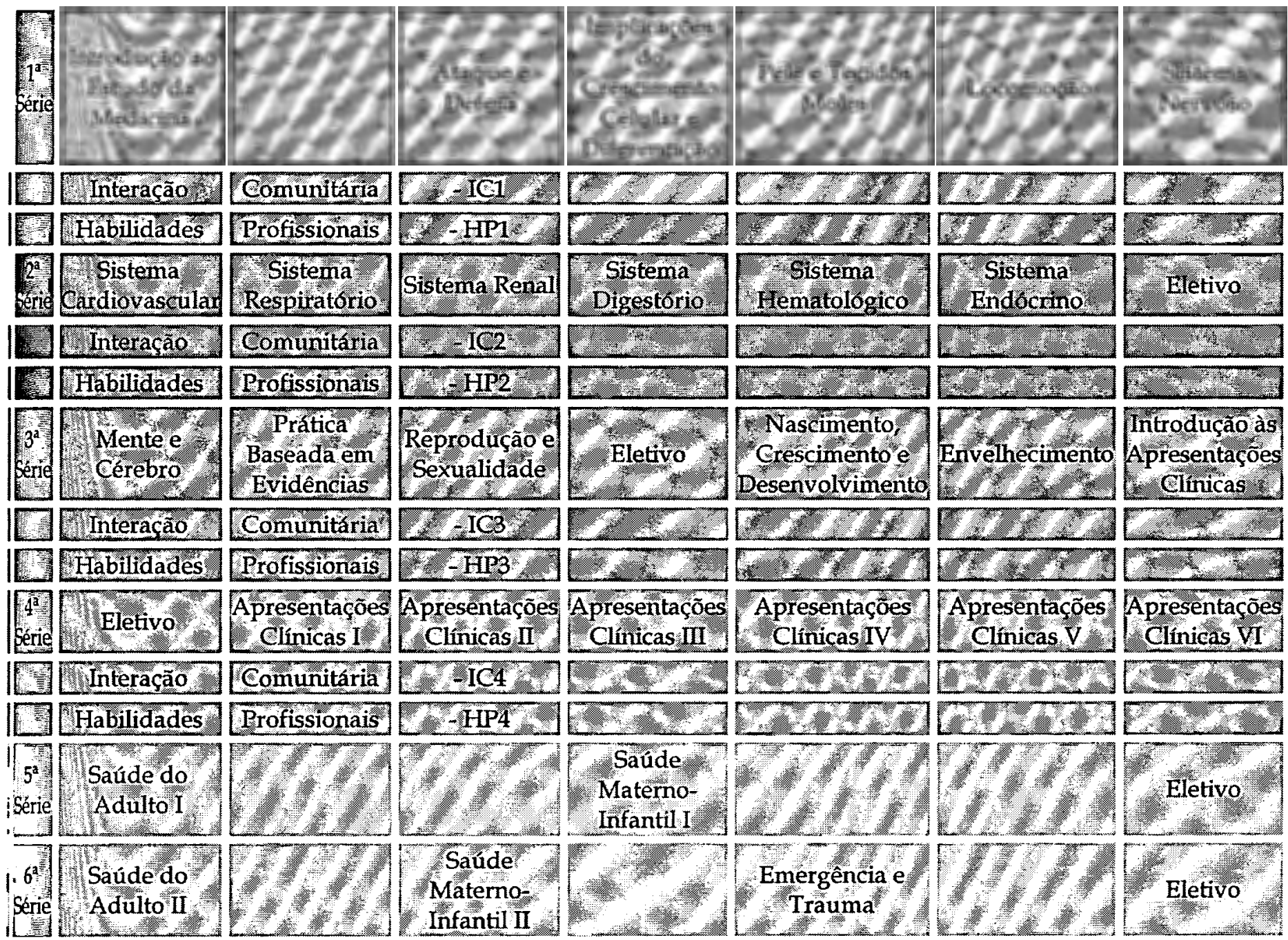

Fonte: Aprendizagem Baseada em Problemas (KOMATSU et al, 1998)

A participação dos docentes como tutores foi identificada como o principal mecanismo "de conversão", de adesão dos docentes à nova proposta. Essa foi explicitamente uma opção para conquistar governabilidade, pois era mais fácil convencer os docentes a respeito da necessidade de uma mudança metodológica (já que havia uma grande insatisfação com a metodologia tradicional) (entrevistados M1, M2, M3).

A capacitação docente continuou sendo, como nos primeiros anos do UNI, uma das principais estratégias de convencimento dos docentes. Inicialmente a 
capacitação estava muito centrada na tutoria: capacitação básica e depois avançada de tutores.

Em 1999 o curso de capacitação básica era composto fundamentalmente por atividades de tutoria (65\% do tempo) e por capacitação em áreas como: reflexão sobre "ser docente"; princípios da educação de adultos; a metodologia da aprendizagem baseada em problemas; o papel do tutor; o novo curso médico: objetivos gerais e grade curricular; a integração dos vários componentes do currículo; dinâmica de grupo; avaliação; medicina baseada em evidências; bioética. A capacitação avançada nesse momento consistia em 40 horas de atividades, aprofundando os temas de dinâmica de grupo; avaliação; bioética e medicina baseada em evidências. A participação em algum tipo de capacitação era inicialmente compulsória para todos os docentes.

A Figura 30 mostra como, em 1999, terceiro ano da implantação, foi a participação dos docentes nas atividades de capacitação.

Figura 30. Participação dos docentes segundo núcleo disciplinar de origem nas atividades de capacitação de tutores na FAMEMA em 1999.

\begin{tabular}{|l|c|c|c|}
\hline $\begin{array}{l}\text { Núcleo } \\
\text { disciplinar }\end{array}$ & $\begin{array}{l}\text { Número total de } \\
\text { docentes }\end{array}$ & \multicolumn{1}{c}{$\begin{array}{l}\text { Número de docentes na } \\
\text { Capacitação Básica }\end{array}$} & $\begin{array}{l}\text { Número de docentes na } \\
\text { Capacitação avançada }\end{array}$ \\
\hline Básicas & 23 & 4 & 15 \\
\hline Clínica Médica & 67 & 18 & 13 \\
\hline Clínica Cirúrgica & 50 & 11 & 3 \\
\hline Pediatria & 20 & 4 & 3 \\
\hline G-Obstetrícia & 9 & 2 & 7 \\
\hline Saúde Coletiva & 21 & 5 & 5 \\
\hline Saúde Mental & 20 & 2 & 1 \\
\hline Informática & 1 & 0 & \\
\hline
\end{tabular}

Fonte: PROJETO UNI MARILIA. Relatório de avaliação do período maio/98 a julho/99. (PROJETO, 1999).

A figura 31 mostra a participação dos docentes nas várias atividades do novo currículo no terceiro ano de implantação: 
Figura 31. Participação dos docentes segundo núcleo disciplinar de origem nas atividades do novo currículo de medicina da FAMEMA em 1999.

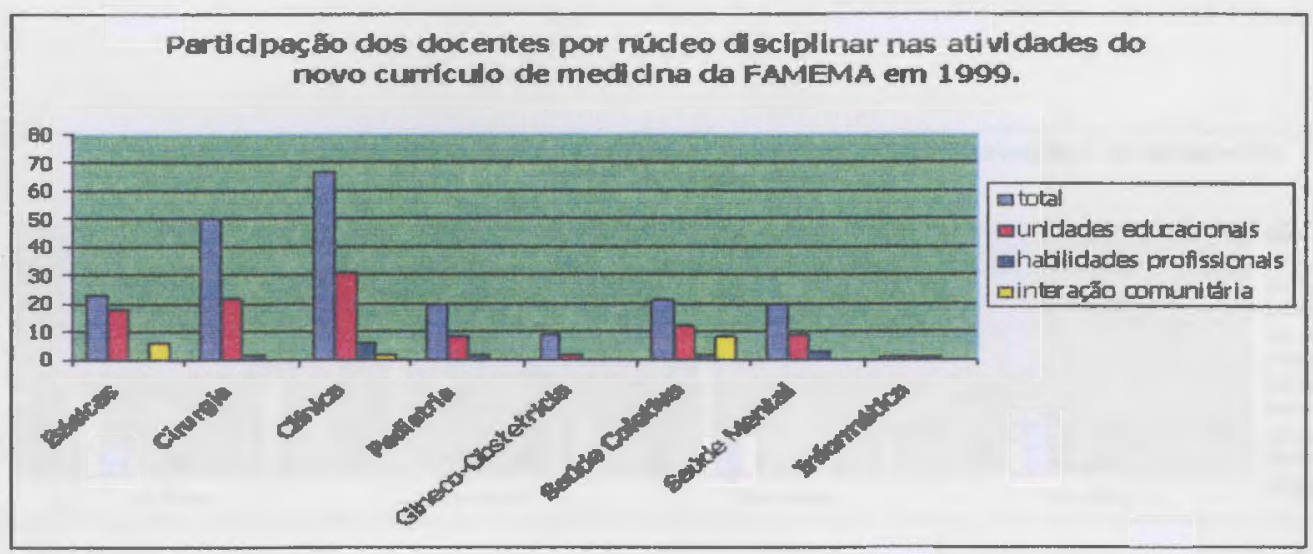

Fonte: PROJETO UNI MARILIA. Relatório de avaliação do período maio/98 a julho/99 (PROJETO, 1999).

Como se vê, havia, proporcionalmente, uma participação mais significativa dos docentes das áreas básicas, da saúde mental e da saúde coletiva. Com o tempo essa participação foi se equilibrando.

Em 2001, por exemplo, a participação dos docentes nas unidades de todas as séries (com exceção da $4^{\mathrm{a}}$.) já estava mais homogênea. Como se vê na próxima figura, no cômputo geral, as duas áreas com menor participação são a Pediatria e a Ginecologia-Obstetrícia; na 4a .série, ao contrário das demais, não há tutores da área básica. 
Figura 32 Distribuição dos docentes por núcleo disciplinar de origem nas atividades de tutoria por série do curso de medicina da FAMEMA em 2001.

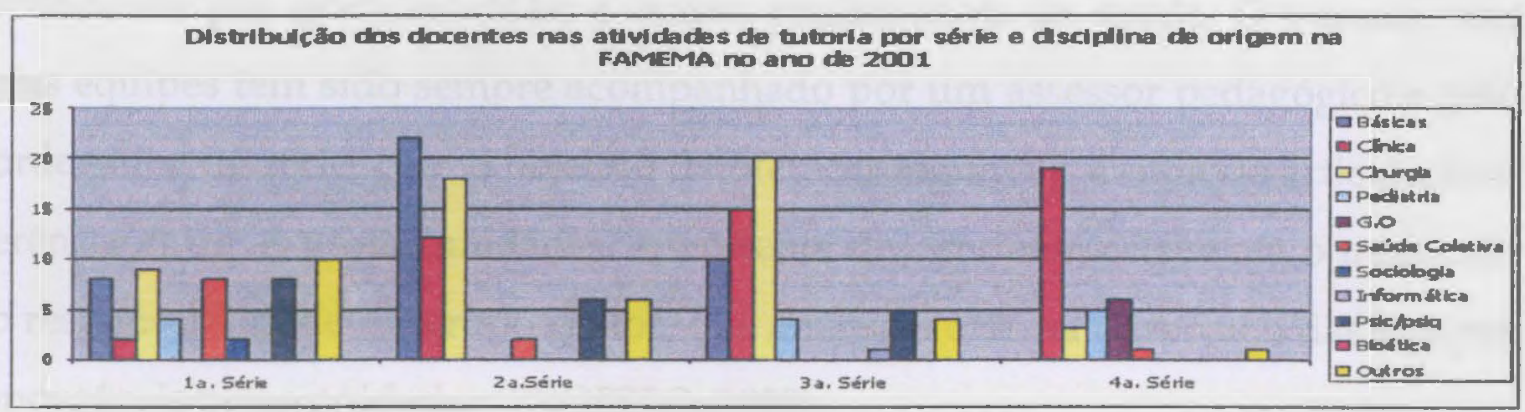

Fonte: Manuais das unidades educacionais. (FACULDADE, 2001a)

Segundo o entrevistado M3, um número importante de docentes era cético em relação às mudanças no início da implantação. "Mas ao verem que a coisa era para valer, foram se incorporando e rapidamente ficando entusiasmados" com as novas práticas a as novas abordagens.

O grupo de oposição estava majoritariamente concentrado na Saúde Coletiva e manteve, durante toda a implantação, uma participação limitada no currículo. Estiveram sempre mais inseridos no novo curso de Enfermagem. Mesmo eles, entretanto, foram progressivamente assumindo responsabilidades, como, por exemplo, na área da Epidemiologia Clínica.

\subsubsection{O projeto político-pedagógico}

Com a implantação do Projeto FAMEMA 2000, foram estabelecidos nova dinâmica, novos papéis e novas relaçð̃es de poder dentro do curso médico. $\mathrm{O}$ 
planejamento curricular passou a ser coordenado pelo grupo gestor do curso, que deveria agregar todas as coordenações de séries, do internato, as coordenações das unidades longitudinais e da avaliação (PROJETO, 1999).

O processo de construção curricular obedece a duas dinâmicas: uma ascendente e outra descendente. $\mathrm{Na}$ vertente ascendente participam os docentes responsáveis pelas unidades (representantes das disciplinas, especialistas, responsáveis por grandes áreas) e outros profissionais da saúde. $O$ trabalho das várias equipes tem sido sempre acompanhado por um assessor pedagógico e pelo coordenador de série, com o objetivo de oferecer alguma garantia de articulação e coerência entre as várias unidades. A vertente descendente esteve até o momento sob responsabilidade do grupo gestor, que analisa e orienta o trabalho das equipes responsáveis pelas unidades (PROJETO, 1999).

Em setembro de 2001, o Fórum de Desenvolvimento Curricular, que contou com a participação de aproximadamente 70 docentes, identificou as limitações dessa dinâmica, considerando que ela não estava sendo suficiente para garantir integração e articulação entre as unidades. Foram propostos, então, alguns mecanismos novos para revisão e reconstrução das unidades, como a ativação da Câmara de Graduação (ou Colegiado) para discussão e definição de princípios, o estabelecimento de um espaço de integração entre os coordenadores de unidades de cada série para definição de conteúdos, construção conjunta de algumas unidades, assessoria pedagógica mais efetiva no processo de construção das unidades, entre outros (FORUM, 2001).

Além da revisão da grade curricular, houve também uma reconstrução dos objetivos perseguidos pelo processo de mudança. Através de duas oficinas de trabalho, utilizando uma adaptação da técnica Delphi, foram construídas a missão do curso médico e as competências pretendidas pelo programa (PROJETO, 1999).

A missão ficou assim definida: "Desenvolver elevados padrōes de excelência no exercício da medicina, na geração e disseminação do conhecimento científico e de práticas de 
intervenção, que expressem efetivo compromisso com a melhoria da saúde e com os direitos das pessoas" (PROJETO, 1999).

As competências para o curso médico foram agrupadas em cinco áreas: ética e relacionamento interpessoal e educação permanente (consideradas institucionais), prática clínica (considerada específica da carreira médica), gestão e planejamento e contexto da prática profissional (consideradas específicas das equipes de saúde).

As competências institucionais são as que devem ser desenvolvidas por todos os profissionais da instituição, embora com diferentes graus de profundidade e autonomia. As competências específicas da carreira diferenciam e particularizam a ação profissional e as competências das equipes de saúde são aquelas que são produto de um processo de interação e troca de conhecimentos entre as várias profissões, possibilitando melhor compreensão e propostas mais potentes de intervenção sobre a realidade (PROJETO, 1999).

Vale a pena explicitar as definições das várias competências:

"Ética e relacionamento interpessoal:

- Orientar o exercício profissional para as necessidades dos pacientes e seus familiares, estabelecendo uma relação baseada no reconhecimento dos valores e manifestações sócio-culturais nelas envolvidos;

- Posicionar-se ética e humanisticamente nas diferentes dimensões do exercicio profissional, que envolvem a atenção ao indivíduo, à comunidade e a relação com outros profissionais;

- Reconhecer-se integrante da complexa relação estabelecida entre profissionais e outros membros da equipe de saúde

- Comunicar-se com eficiência em contextos de natureza diversa: interpessoal, organizacional e de pequenos grupos.

Educação permanente:

- Acompanhar e avaliar de forma contínua e crítica o desenvolvimento do conhecimento e da tecnologia em saúde para orientar propostas inovadoras e comprometidas com a qualidade do cuidado às pessoas 
- Entender o processo permanente de aprendizagem vivenciado no exercício profissional, reconhecendo suas dificuldades, erros $e$ limitações do conhecimento.

Prática clínica

- Identificar, integrar e avaliar sob a perspectiva clínica e epidemiológica dados colhidos na história clínica e de vida do paciente, no exame fisico e na exploração diagnóstica complementar.

- Realizar procedimentos clínico-terapêuticos essenciais no atendimento às urgências/emergências e calamidades, principalmente aqueles envolvidos na preservação e na qualidade de vida.

Contexto profissional

- Identificar as possibilidades de intervenção em relação à promoção, prevenção, tratamento e reabilitação nos planos individual, familiar $e$ comunitário, segundo a ocorrência, distribuição e impacto dos problemas de saúde da comunidade.

- Escolher de forma compartilhada com o paciente e outros profissionais da equipe os procedimentos diagnósticos e terapêticos mais apropriados, com base nas relações de risco, custo e beneficio e no consentimento informado.

- Reconhecer os limites e possibilidades do trabalho em saúde na transformação de sua área de atuação, interpretando as implicações da organização dos sistemas nacional e local de saúde na prática profissional e na gestão em saúde.

Gestão e planejamento

- Planejar o acompanhamento e/ou encaminhamento do paciente usando como referência as necessidades e possibilidades deste e de seus familiares, assim como os recursos assistenciais disponíveis.

- Intervir nos problemas de saúde identificados em sua área de atuação, utilizando instrumental de planejamento e programação em saúde" (PROJETO, 1999). 
Essa foi, na verdade, uma redefinição mais profunda, completa e organizada, do que se pretendia alcançar com o processo de mudança. Embora essas sejam definições situadas no campo das intenções, do dever ser, elas tiveram influência prática importante nas redefinições e caminhos escolhidos para continuar implementando a mudança.

Esses novos conteúdos claramente se refletem na opinião dos diversos atores a respeito de qual a principal característica da nova proposta. Os docentes consideram que o novo currículo está "muito mais comprometido com as necessidades dos estudantes (embora haja polêmicas em relação ao conceito de "centrado no estudante"), é "baseado em problemas" e "busca uma articulação das dimensões biológicas, psicológicas e sociais na abordagem do processo saúde -doença", "busca essencialmente uma formação mais humanista", "parte do conhecimento que o aluno já tem e estimula sua busca por novos conhecimentos", "provocou uma mudança na dedicação do professor à docência", "estimulou os docentes a estudar e a aprender a aprender" (grupo focal de docentes M).

Os estudantes consideram que as principais características da nova proposta são "desenvolver nos estudantes responsabilidade e visão crítica", "desenvolver visão integral, tratando o paciente como um todo e não como uma doença", "estimular o estabelecimento de uma relação médico-paciente menos restrita e mais respeitosa", "estimular o raciocinio clínico", "possibilitar uma visão integrada das matérias", "aprender a buscar o conhecimento, já que o médico vai ter que aprender a vida toda" (grupo focal dos estudantes M).

Para os profissionais dos serviços e os representantes da comunidade, a nova proposta possibilita "que os estudantes tenham uma visão mais ampla da saúde", "que estejam mais próximos da comunidade e mais integrados com os serviços de saúde", "formar profissionais com prática mais humanizada, com maior compromisso com o trabalho que fazem junto à comunidade","que os estudantes sejam mais críticos em relação às práticas tradicionais", "também contribui para a mudança que está acontecendo nos serviços de saúde, reforçando a mudança do modelo". (grupo focal dos profissionais dos serviços e representantes da comunidade $M)$.

As novas definições a respeito da missão institucional e das competências que se pretende desenvolver também foram essenciais para que se iniciasse um 
trabalho exaustivo de busca da integração entre as dimensões biológicas, psicológicas e sociais na nova proposta.

Foram também orientadoras dos novos rumos que assumiu o processo de capacitação docente. Na prática, durante a implementação do currículo, foi ficando claro, para o grupo gestor que, para atingir os objetivos desejados, o processo de mudança tinha que ser muito mais profundo e envolvia muitas outras esferas além da pedagógica. Mais uma vez a capacitação foi eleita como uma das estratégias centrais para possibilitar aos docentes a reflexão não somente sobre a construção curricular e sobre sua prática pedagógica, como também sobre outras esferas de sua prática.

Como conseqüência, em 2001 a proposta de capacitação docente avançada foi radicalmente transformada. Passou a ser concebida como processo de educação permanente dos docentes e, portanto, a envolver as várias esferas da atuação docente e não somente o trabalho de tutoria.

São duas as modalidades de intervenção propostas para o programa: uma através de cursos, de aproximadamente 20 horas de duração cada um, "que abordam temas específicos considerados relevantes para o aprofundamento e sedimentação dos conhecimentos exigidos para fazer frente às novas exigências do projeto politico- pedagógico da faculdade". (FACULDADE, 2002).

Cada docente deve eleger no mínimo dois módulos para frequientar ao longo do ano. Em 2001 foram oferecidos os seguintes módulos (PROJETO, 2001):

- (Re)pensando o currículo: em busca do desenvolvimento curricular permanente.

- Prática baseada em evidências

- Bioética

- Avaliação formativa do estudante

- Dinâmica de grupo

- Acesso à informação em saúde

- Refletindo sobre a problematização 
- (Des)construindo unidades educacionais em ABP

- Educação em saúde.

A outra vertente do Programa de Educação Permanente busca oferecer oportunidades de reflexão organizada e sistemática sobre a prática em cada um dos espaços de atuação docente. De acordo com esse espírito, no ano 2002 estão previstas as seguintes linhas de trabalho (FACULDADE, 2002):

- Junto aos tutores

- assessoria para seu aprimoramento através de reuniões sistemáticas ao longo do desenvolvimento das unidades, favorecendo a compreensão da proposta metodológica, seus fundamentos e implicações

- devolutiva das avaliações de desempenho em sessões de tutoria através do debate acerca do produto obtido pela análise de conteúdo desse material

- Junto aos preceptores do internato

- Oficinas de trabalho para construir as novas diretrizes para o trabalho dos preceptores em coerência com os princípios da nova proposta, partindo de uma reflexão sobre o processo de ensinoaprendizagem no internato;

- Oficinas de trabalho sobre o processo de avaliação, buscando introduzir as bases para a avaliação de desempenho;

- Assessoria aos preceptores através de reuniões semanais com o objetivo de oferecer suporte específico de acordo às necessidades identificadas ao longo do desempenho da função.

- Junto aos orientadores de estudantes de medicina

- Resgatar, rediscutir, refletir e reconstruir com os docentes do curso de medicina a função de orientação no programa educacional da FAMEMA. 
- Junto aos docentes do curso de enfermagem

- Assessoria em reuniões semanais para reflexão sobre a prática docente, criando espaços coletivos para a reconstrução do projeto político-pedagógico do curso. O ponto de partida para o debate será a articulação teoria-prática e seu papel fundamental na metodologia da problematização.

Houve também uma mudança importante nas normas institucionais no campo das definições e exigências em relação ao trabalho docente. Segundo as novas regras, todos os docentes têm que dedicar ao menos $50 \%$ de sua carga horária para a docência, quando antes dedicavam menos de $20 \%$ para o trabalho do $1^{\circ}$ ao $4^{\circ}$ ano (grupo focal dos docentes $\mathrm{M}$ ).

Há uma importante mudança de qualidade na dedicação e na compreensão dos docentes acerca de seu trabalho:

"Existe hoje um envolvimento dos docentes com a causa educacional. Em função das relações mais horizontais e próximas com os estudantes, há mais compromisso e responsabilidade. Entrou na pauta deles discutir a educação, a didática, os métodos. Neste ano a adesão ao processo de capacitação foi voluntária: isso fez muita diferença porque as pessoas puderam escolher as áreas realmente de interesse e o grupo chegava muito mais motivado para a discussão" (entrevistado M5).

“O mapa (das atividades docentes) também foi um avanço enorme em termos de organização desta instituição. O ensino de graduação passou a ser realmente um compromisso coletivo. Antes os programas das disciplinas eram programas xerocados: só mudava o ano e mais nada. Agora o processo é incomparável: grupos de planejamento das unidades, montagem dos cadernos, montagem das avaliações, planos de recuperação, as correções". (entrevistado M5).

"Os docentes falam de coisas diferentes, se apropriam de outras áreas, trabalham em grupo, se conhecem. É muita diferença!" (entrevistado M5). 
Há também novas relações de poder em relação ao planejamento curricular, já que os conteúdos a serem abordados não são definidos mais de acordo com os desígnios dos departamentos ou do professor encarregado de cada disciplina.

Há um compromisso maior dos professores com o ensino, com o que está acontecendo com os estudantes. Muitos professores valorizam bastante os fortes vínculos que agora são possíveis entre professores e estudantes, bem como a possibilidade de conhecimento mais profundo em relação às necessidades de apoio requeridas pelos estudantes. Outros, no entanto, sentem "saudade" do tempo em que eram "conhecidos" por um número maior de estudantes, como se daquele modo sua possibilidade de influir fosse maior - apesar de a relação estabelecida com os grupos de 80 , em aulas magistrais, ser reconhecida por todos como mais superficial (grupo focal dos docentes $M$ ).

Os estudantes passaram a ocupar papel central na conformação do processo de ensino-aprendizagem e valorizam seu papel ativo na melhoria do curso. Alguns destacam a dinâmica de avaliação e mudanças constantes no currículo e na organização do processo de ensino-aprendizagem como prova do compromisso institucional com a qualidade, e outros reclamam do que chamam de "falta de definiçōes claras a respeito do projeto institucional - se mudam tanto, é porque não sabem para onde querem ir". Alguns apreciam muito sua nova liberdade e a responsabilidade na definição da dinâmica do processo de aprendizagem. Outros se mostram ansiosos e inseguros, "não tendo clareza de até onde é necessário chegar" (grupo focal dos estudantes M).

Há também novas relações de poder na definição das atividades realizadas junto aos serviços de saúde, pois existe planejamento conjunto, negociação e consideração de necessidades e possibilidades recíprocas. Os profissionais dos serviços reconhecem inclusive que têm um papel a cumprir na mudança das aspirações dos estudantes em relação à prática profissional futura: "tem todo um trabalho nosso, do serviço, de mostrar um modelo que funciona diferente, que funciona melhor, para 
o aluno poder comparar" (grupo focal dos profissionais dos serviços e representantes da comunidade $M$ ).

A comunidade participante do projeto aparece mais como expectadora do processo, tudo acompanhando, mas com dificuldades para identificar meios efetivos de intervenção. Houve muitas decepções em relação ao funcionamento dos Conselhos de Saúde e não foi lhes possível encontrar canais orgânicos para estar junto nesse trabalho desenvolvido por docentes, estudantes e profissionais dos serviços na esfera da atenção básica.

Na própria implantação da Saúde da Família essa dificuldade fica clara: “ $a$ gente tem poucos conselheiros que conseguiram fazer essa coisa de trazer realmente a demanda da população; então estamos fazendo movimentos de ligação direta, de convocação à participação direta da comunidade e está funcionando muito melhor" (grupo focal dos profissionais dos serviços e representantes da comunidade $\mathrm{M}$ )

O projeto UNI, entretanto, abriu possibilidades para outros tipos de trabalho para a comunidade, que agora surgem como possibilidades de campo de intervenção conjunta para os estudantes, para além do espaço específico da atenção à saúde, como por exemplo, o movimento de desfavelamento, a coleta seletiva de lixo e o trabalho de saneamento ambiental (grupo focal dos profissionais dos serviços e representantes da comunidade $\mathrm{M}$ ).

\subsubsection{A concepção de currículo}

A busca pela articulação interdisciplinar na construção dos conteúdos a serem trabalhados na graduação e na definição de linhas de investigação era algo importante na nova proposta, tanto que foi esse o eixo adotado para definir a reorganização da faculdade: os departamentos foram extintos e foram criados os Grupos Interdisciplinares de Trabalho.

Do ponto de vista da organização e da definição dos conteúdos curriculares houve um avanço importante, já que a construção de cada unidade passou a ser feita em conjunto por uma equipe de profissionais das várias áreas. As próximas 
figuras mostram como os docentes das várias disciplinas participaram da coordenação e do trabalho de planejamento das unidades.

Figura 33. Participação dos docentes segundo núcleo disciplinar de origem no trabalho de coordenação das unidades educacionais do $1^{\circ}$ ao $4^{\circ}$ ano do curso médico na FAMEMA em 2001.

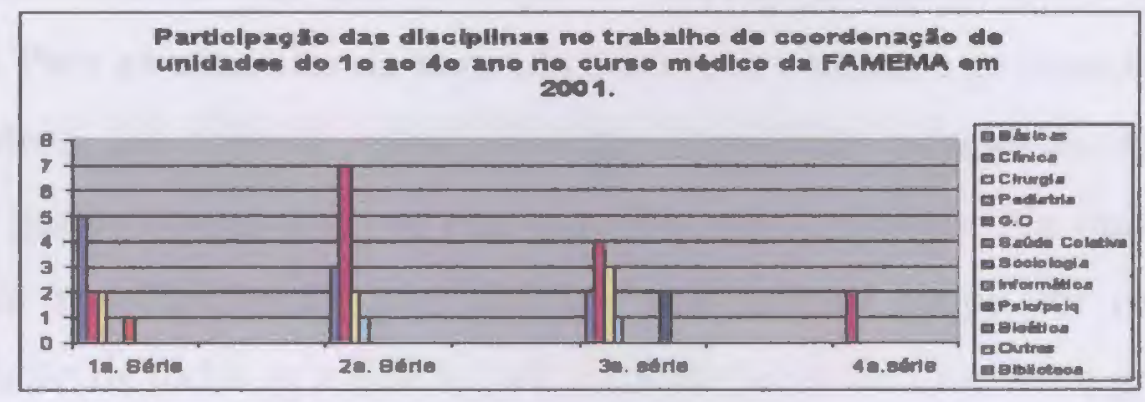

Fonte: Manuais das unidades educacionais. (FACULDADE, 2001a)

Figura 34 Participação dos docentes segundo núcleo disciplinar de origem no planejamento das unidades educacionais do curso de medicina da FAMEMA em 2001.

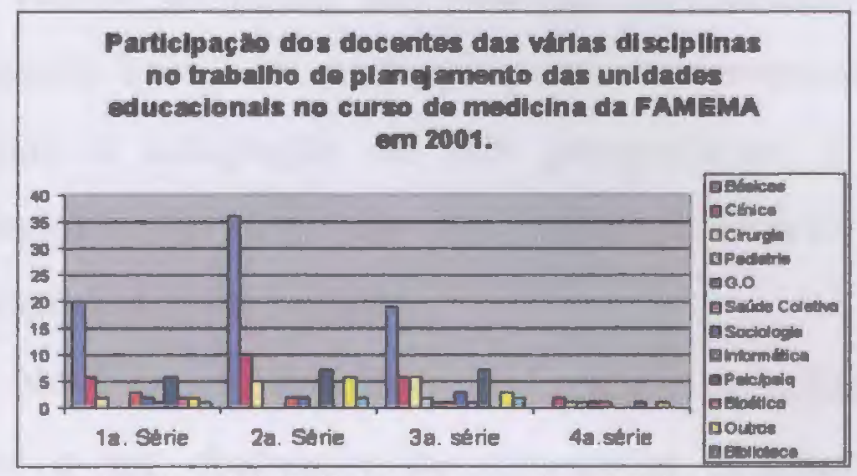

Fonte: Manual do Unidades EducaclonsIs.FAMEMA, 2001

Essa metodologia de construção das unidades favorece a articulação interdisciplinar dentro de um determinado tema, mas não assegura que exista articulação entre várias unidades, nem coerência entre os objetivos educacionais 
das unidades entre si e entre os objetivos de cada uma delas e os do programa como um todo.

Essa preocupação esteve sempre presente e essa era uma tarefa atribuída ao Comitê Gestor do Currículo. Para as unidades do primeiro ano houve a construção de orientações para facilitar a elaboração das unidades de acordo com os princípios gerais e essa construção (da orientação geral) foi responsabilidade fundamentalmente de dois professores (diretor de graduação e coordenador do curso). Para as unidades da segunda e a terceira séries, o processo foi mais solto, e a coerência foi buscada principalmente através de assessorias dos membros do grupo gestor aos grupos de planejamento das unidades. Na quarta série, que é baseada nas Apresentações Clínicas ${ }^{7}$, um mesmo grupo foi responsável pela construção de todas as unidades sob a coordenação do diretor de graduação.

Aparentemente o objetivo mais bem atingido com esse processo foi o de garantir que todos os conteúdos fundamentais estivessem presentes ao longo das 4 primeiras séries. Especialmente porque as revisões constantes e o processo permanente de avaliação das unidades ofereceram possibilidades para que as necessárias alterações fossem feitas e lacunas cobertas. Mas essa não foi uma construção do coletivo de professores.

Ainda do ponto de vista da articulação entre as disciplinas, desde a formulação inicial da nova proposta expressava-se com força a necessidade de propiciar a integração de três perspectivas: a biológica, a psicológica e a populacional. Ao longo dos dois primeiros anos de implementação houve também mudanças nessa formulação.

No Guia de Processo de Ensino-Aprendizagem de 1999, as perspectivas passam a ser chamadas de dimensões e houve mudanças significativas na

\footnotetext{
${ }^{7}$ Apresentações clínicas são representações de situações complexas, comuns ou importantes, em que pacientes ou coletivos requerem atenção dos profissionais de saúde e diante das quais espera-se que o graduado seja capaz de uma conduta adequada. Uma apresentação clínica deve, portanto, ser complexa o suficiente para exigir uma abordagem interdisciplinar e envolver extensa área de conhecimentos e habilidades (KOMATSU, 2001)
} 
formulação das dimensões psicológicas e das agora denominadas dimensões sociais.

A dimensão psicológica é definida como dizendo respeito "ao componente psicológico do ser humano, aos seus processos mentais (cognitivos, emocionais) que influenciam e/ou determinam o comportamento" e também "às inter-relações do ser humano com a sociedade - que altera as pessoas e é por elas alterada", assim como "o componente psicológico do ser humano, em suas interfaces com os processos biológicos, exerce e recebe influências - altera-os e por ele é alterado" (KOMATSU et al, 1999).

Diz-se também que a dimensão psicológica não deve ser vista apenas como "um dos aspectos que individualiza e identifica cada situação e que torna necessária uma constante apreensão da realidade", mas também "como um aspecto fundamental na compreensão da própria determinação do adoecer" ...e "como um determinante essencial do prognóstico, quando se observa como cada doente se relaciona com a própria doença, com as perdas e os ganhos secundários..." (KOMATSU et al, 1999).

E definida agora como fundamental para uma adequada apreensão da dimensão psicológica "uma compreensão abrangente sobre as influências e determinações dos aspectos genéticos, sociais (culturais, religiosos, econômicos), da dinâmica familiar e do seu desenvolvimento na estruturação da personalidade" (KOMATSU et al, 1999).

Diz-se também que:

"a identificação dessas características fundamentais, que dão sentido e distinguem o ser humano em seus processos intra $e$ interpessoais, são elementos básicos para o estabelecimento de uma relação médico-paciente baseada no respeito à autonomia do paciente e em uma adequada dinâmica de comunicação". (KOMATSU et al, 1999).

A dimensão social também é formulada de maneira diferente: parte-se da constatação de que "as doenças não se distribuem de forma homogênea e perfeitamente aleatória nos diferentes grupos e sociedades", sendo necessário, portanto, "explorar os determinantes que possam explicar essas diferenças". Reconhece-se que "as condições de saúde das pessoas $e$ dos grupos sociais são resultado de processos que se produzem socialmente", dependendo das 
condições em que vivem, moram e trabalham e das relações que estabelecem as pessoas e os diferentes grupos sociais (KOMATSU et al, 1999).

Destaca-se que as relações entre as várias dimensões do processo-saúde doença não são lineares, de modo que os processos históricos subordinam os sociais, que subordinam os epidemiológicos, que subordinam os clínicos e estes os fisiopatológicos (KOMATSU et al, 1999).

Há um esforço por traduzir a linguagem da saúde coletiva a expressões e explicações que sejam compreensíveis para os estudantes e para os médicos em geral, dizendo, por exemplo, que "o contexto precisa ser identificado para que melhoremos nossa capacidade de oferecer ações de saúde mais adequadas e necessárias para as pessoas, grupos de pessoas e para a sociedade" (KOMATSU et al, 1999).

Finalmente, diz-se que para compreender a dimensão social do processo saúde-doença é necessário lançar mão dos conhecimentos de várias disciplinas como a epidemiologia, economia em saúde, administração em saúde, sociologia, antropologia, bioestatística, ciências políticas, direito, ética, ciências clínicas e educação.

Destacam também que, ao procurar integrar essas três dimensões, o programa de medicina da FAMEMA busca a "formação de um profissional de saúde mais adequado às necessidades da sociedade, capaz de identificar sua história e determinantes e, acima de tudo, comprometer-se socialmente com essas pessoas, trabalhando para a melhoria de suas condições de saúde e de vida" (KOMATSU et al, 1999).

Apesar de haver essa firme disposição de integração, esse tem sido um desafio importante na implementação da nova proposta. De acordo com estudo de LIMA (2000), que analisou os objetivos das unidades educacionais da $1^{\mathrm{a}}$ e da $2^{\mathrm{a}}$ séries utilizadas no ano de 1998, no geral os objetivos específicos dirigidos à dimensão biológica apresentavam uma clara definição do conteúdo a ser explorado. Já os objetivos relacionados à dimensão social freqüentemente apareceram com redação mais vaga, com pouca delimitação do conteúdo a ser explorado e com redução das potencialidades para sua exploração. 
De acordo com esse mesmo estudo, a abordagem da dimensão social nas unidades educacionais foi "predominantemente percebida no manejo das doenças", "as condições sociais foram naturalizadas e desprovidas de seu caráter histórico" e "a ação dos profissionais de saúde nesse contexto ficou restringida às relações causais e mecânicas" (LIMA,2000).

A partir dessas constatações, foi desencadeado um processo sistemático e coletivo de reflexão em torno do tema, que inicialmente envolveu o grupo gestor e depois o coletivo de professores, especialmente no processo de construção das unidades e dos exercícios de avaliação cognitiva (que passaram a ser validados em função dos objetivos das unidades educacionais).

Vários aportes foram buscados, considerando que, apesar de haver o reconhecimento coletivo da importância dessa abordagem integral, havia profundas dificuldades para desenvolvê-la na prática. Um dos caminhos propostos foi o da clínica ampliada que, além de preconizar a organização das equipes de saúde em função das necessidades dos pacientes (o que implica articulação horizontal dos especialistas nas grandes áreas e matricial dos subespecialistas), também busca ampliar o "arsenal" dos profissionais das grandes áreas especialmente com alguns elementos da área da saúde mental (CAMPOS, 1999). Foi com essa lógica que se iniciou o planejamento do internato e uma reorganização do Hospital das Clínicas em 2001.

Outro caminho explorado foi o da conscientização do corpo clínico a respeito da diversidade cultural e de suas repercussões na maneira como diferentes grupos humanos compreendem e enfrentam os processos de viver, adoecer, sofrer e morrer e as dificuldades de comunicação que derivam dessas diferenças.

No final de 2001, a partir de uma demanda do Fórum de Desenvolvimento Curricular, a equipe de avaliação procedeu a uma primeira análise sistemática (quantitativa) dos objetivos educacionais e dos problemas utilizados em todas as unidades educacionais da $1^{\mathrm{a}}$ à $4^{\mathrm{a}}$ séries. 
Os objetivos educacionais da $1^{\mathrm{a}}$ à $4^{\mathrm{a}}$ séries foram classificados segundo os domínios cognitivo, afetivo e psicomotor, segundo o grau de complexidade do desenvolvimento de cada domínio e segundo as dimensões abordadas (biológica, psicológica e social) (PROJETO, 2001).

$\mathrm{Na} 1^{\mathrm{a}}, 2^{\mathrm{a}}$ e $3^{\mathrm{a}}$ séries houve um predomínio do domínio cognitivo. Na $4^{\mathrm{a}}$ série, houve uma maior presençă de objetivos classificados nos domínios afetivo e psicomotor, provavelmente porque as atividades predominantes nesse ano são estágios dos estudantes nas unidades básicas de saúde e unidades do programa da saúde da família (PROJETO,2001). Essa evolução está apresentada na Figura 35:

Figura 35 - Distribuição percentual dos objetivos educacionais segundo domínio nas 4 primeiras séries do curso de medicina da FAMEMA em 2001.

\begin{tabular}{|l|c|c|c|c|}
\multicolumn{1}{c}{ Domínio } & \multicolumn{1}{c}{$\mathbf{1}^{2}$ série } & $2^{2}$ série & $3^{\mathbf{a}}$ série & $\mathbf{4}^{\mathrm{a}}$ série \\
\hline C - Cognitivo & $74,8 \%$ & $79,8 \%$ & $83,0 \%$ & $53,3 \%$ \\
\hline A - Afetivo & $16,5 \%$ & $9,7 \%$ & $3,8 \%$ & $24,4 \%$ \\
\hline P - Psicomotor & $1,9 \%$ & $1,6 \%$ & $1,9 \%$ & $20,0 \%$ \\
\hline CP & $5,8 \%$ & $0,8 \%$ & $2,8 \%$ & $2,2 \%$ \\
\hline CA & - & $0,8 \%$ & - & - \\
\hline CAP & $1,0 \%$ & $7,3 \%$ & $8,5 \%$ & - \\
\hline
\end{tabular}

Fonte: PROJETO UNI MARILIA. Relatório de avaliação da fase de consolidação 2000- 2001 (PROJETO, 2001).

Em relação ao domínio cognitivo, conforme taxonomia de Bloom (1971), os objetivos educacionais voltados à memorização (taxonomia 1) tiveram maior peso proporcional nas unidades educacionais da $1^{\mathrm{a}}$ à $3^{\mathrm{a}}$ séries. Na $4^{\mathrm{a}}$ série, os objetivos classificados como taxonomia 2 e 3 (compreensão, aplicação, análise, síntese e avaliação) representaram 82,2\% do total. É o que mostra a Figura 36 . 
Figura 36 - Distribuição percentual dos objetivos educacionais segundo taxonomia do domínio cognitivo nas 4 primeiras séries do curso de medicina da FAMEMA em 2001.

\begin{tabular}{|c|c|c|c|c|}
\hline Taxonomia & $1^{a}$ série & $2^{a}$ série & $3^{\mathrm{a}}$ série & $4^{\mathrm{a}}$ série \\
\hline Memorização & $54,4 \%$ & $62,9 \%$ & $62,3 \%$ & $17,8 \%$ \\
\hline Compreensão & $19,4 \%$ & $16,1 \%$ & $8,5 \%$ & $28,9 \%$ \\
\hline Análise, síntese, avaliação & $26,2 \%$ & $21,0 \%$ & $29,2 \%$ & $53,3 \%$ \\
\hline
\end{tabular}

Fonte: PROJETO UNI MARILIA. Relatório de avaliação da fase de consolidação 2000- 2001 (PROJETO, 2001).

A classificação dos objetivos educacionais da $1^{\text {a }}$ a $4^{\text {a }}$ séries segundo dimensão utilizou inicialmente, além das três dimensões definidas no currículo (biológica, psicológica e social), todas as possibilidades de combinação entre essas dimensões. Após essa categorização, todas as dimensões não biológicas (social e psicológica) ou que combinassem duas ou mais dimensões foram consideradas como dimensão ampliada (biopsicológica, biossocial, psicossocial, biopsicossocial).

Dessa forma, os objetivos educacionais foram reagrupados em duas categorias - biológica e ampliada - revelando, com exceção da $2^{\mathrm{a}}$ série, um maior peso proporcional da dimensão ampliada:

Figura 37 - Distribuição percentual dos objetivos educacionais segundo dimensão nas quatro primeiras séries do curso de medicina da FAMEMA em 2001.

\begin{tabular}{|c|c|c|c|c|}
\hline Dimensão & $\mathbf{1}^{\mathrm{a}}$ série & $\mathbf{2}^{\mathrm{a}}$ série & $\mathbf{3}^{\mathrm{a}}$ série & $\mathbf{4}^{\mathrm{a}}$ série \\
\hline Biológica & $\mathbf{4 4 , 7} \%$ & $58,1 \%$ & $30,2 \%$ & $35,6 \%$ \\
\hline Ampliada & $55,3 \%$ & $41,9 \%$ & $69,8 \%$ & $64,4 \%$ \\
\hline
\end{tabular}

Fonte: PROJETO UNI MARILIA. Relatório de avaliação da fase de consolidação 2000- 2001 (PROJETO, 2001).

Uma hipótese para explicar essa diferença de possibilidades de integração entre as séries foi a de que a divisão das unidades da $2^{\mathrm{a}}$ série por sistemas orgânicos teria favorecido maior peso proporcional da dimensão biológica e da memorização. No Fórum de Avaliação foi manifestada a intenção de diminuir a fragmentação por sistemas e o excessivo enfoque biológico de algumas das unidades educacionais em questão (FORUM, 2001).

O curso médico utilizou 118 problemas educacionais ao longo das 4 primeiras séries de $2001 . \mathrm{Na} 1^{\text {a }}$ série foram analisados 28 problemas. O caso típico 
teve como objeto de estudo o indivíduo (89,3\%) do sexo masculino (56,5\%), menor de 12 anos (39,1\%), de raça não mencionada (91,3\%), com contexto de vida ausente $(52,2 \%)$ e atendido por profissional médico $(58,1 \%)$. Os temas biológicos foram, proporcionalmente, os mais mencionados $(49,2 \%)$. O cenário do cuidado foi preponderantemente o ambulatório primário $(41,2 \%)$, com enfoque no diagnóstico (27,9\%) e com doença definida (67,9\%) (PROJETO, 2001).

$\mathrm{Na} 2^{\mathrm{a}}$ série foram analisados 29 problemas. O caso típico teve como objeto de estudo o indivíduo (100\%), de ambos os sexos (50\% masculino e $50 \%$ feminino), de 20 a 49 anos $(46,7 \%)$, de raça não mencionada $(86,7 \%)$, com contexto de vida ausente $(53,3 \%)$ e atendido por profissional médico $(93,5 \%)$. Os temas biológicos foram preponderantes $(57,1 \%)$. Os cenários do cuidado proporcionalmente mais presentes foram a atenção primária $(28,2 \%)$ e o ambulatório secundário $(28,2 \%)$, com enfoque no diagnóstico $(49,1 \%)$ e com doença definida $(96,6 \%)$ (PROJETO, 2001).

$\mathrm{Na} 3^{\text {a }}$ série foram analisados 31 problemas. O caso típico teve como objeto de estudo o indivíduo (93,5\%), do sexo feminino (59,4\%), de 20-49 anos (37,9\%), de raça não mencionada (94,6\%), com contexto de vida pouco descrito $(46 \%)$ e atendido por profissional médico $(70,7 \%)$. Os temas biológicos foram proporcionalmente preponderantes $(44,4 \%)$. O cenário do cuidado de maior peso proporcional foi o ambulatório secundário $(40 \%)$, com predomínio de casos clínicos com doença definida $(69,7 \%)$ e enfoque no diagnóstico (35,5\%) (PROJETO, 2001).

$\mathrm{Na} 4^{\text {a }}$ série foram analisados 30 problemas. $\mathrm{O}$ caso típico teve como objeto de estudo o indivíduo (100\%), do sexo feminino (63,3\%), maior de 50 anos $(30 \%)$, de raça não mencionada (60\%), com contexto de vida ausente $(63,3 \%)$ e atendido por profissional médico $(90,9 \%)$. Houve uma maior proporção de temas biológicos $(68,2 \%)$. O cenário do cuidado mais freqüente foi de atenção primária $(40 \%)$, com enfoque no diagnóstico $(48,4 \%)$, de doença definida $(96,7 \%)$ (PROJETO, 2001). 
Foram analisados também os enfoques predominantes nos exercícios cognitivos realizados ao final das unidades. O Exercício de Avaliação Cognitiva (EAC) é composto de 4 a 5 problemas, que orientam 12 a 15 questões escritas sobre o conteúdo de cada unidade. Houve um predomínio da verificação do domínio cognitivo nessas avaliações, ao longo das quatro séries, como se vê na Figura 38:

Figura 38 - Distribuição percentual das questões do EAC segundo domínio nas quatro primeiras séries do curso médico da FAMEMA em 2001.

\begin{tabular}{|l|c|c|c|c|}
\multicolumn{1}{c}{ Domínio } & \multicolumn{1}{c}{$\mathbf{1}^{\mathrm{a}}$ série } & $\mathbf{2}^{\mathbf{a}}$ série & $\mathbf{3}^{\mathrm{a}}$ série & $\mathbf{4}^{\mathbf{a}}$ série \\
\hline C-Cognitivo & $91,8 \%$ & $92,0 \%$ & $98,3 \%$ & $100,0 \%$ \\
\hline A - Afetivo & $6,1 \%$ & $1,1 \%$ & $1,7 \%$ & - \\
\hline P- Psicomotor & - & - & - & - \\
\hline CP & - & - & - & - \\
\hline CA & $2,0 \%$ & $6,9 \%$ & - & - \\
\hline CAP & - & - & - & - \\
\hline
\end{tabular}

Fonte: PROJETO UNI MARILIA. Relatório de avaliação da fase de consolidação 2000- 2001 (PROJETO, 2001).

A análise da taxonomia do domínio cognitivo das questões do EAC mostrou o predomínio do nível de aplicação do conhecimento (compreensão, análise, síntese e avaliação), como mostra a Figura 39:

Figura 39 - Distribuição percentual das questões do EAC segundo taxonomia do domínio cognitivo nas quatro primeiras séries do curso de medicina da FAMEMA em 2001.

\begin{tabular}{|l|c|c|c|c|}
\hline Taxonomia & $1^{\mathrm{a}}$ série & $2^{\mathrm{a}}$ série & $3^{\mathrm{a}}$ série & $4^{\mathrm{a}}$ série \\
\hline Memorização & $26,5 \%$ & $39,1 \%$ & $35,6 \%$ & - \\
\hline Compreensão & $30,6 \%$ & $5,7 \%$ & $33,9 \%$ & $22,2 \%$ \\
\hline Análise, síntese, avaliação & $42,9 \%$ & $55,2 \%$ & $30,5 \%$ & $77,8 \%$ \\
\hline
\end{tabular}

Fonte: PROJETO UNI MARILIA. Relatório de avaliação da fase de consolidação 2000- 2001 (PROJETO, 2001). 
O predomínio da dimensão biológica diminuiu ao longo das séries, havendo quase um equilíbrio entre essa dimensão e a dimensão ampliada, como mostra a Figura 40:

Figura 40 - Distribuição percentual das questões do EAC segundo dimensão nas quatro primeiras séries do curso de medicina da FAMEMA em 2001.

\begin{tabular}{|c|c|c|c|c|}
\hline Dimensão & \multicolumn{1}{c|}{$\mathbf{1}^{2}$ série } & $\mathbf{2}^{2}$ série & $\mathbf{3}^{\mathrm{a}}$ série & $\mathbf{4}^{\mathrm{a}}$ série \\
\hline Biológica & $77,6 \%$ & $75,9 \%$ & $64,4 \%$ & $55,6 \%$ \\
\hline Ampliada $^{*}$ & $22,4 \%$ & $24,1 \%$ & $35,6 \%$ & $44,4 \%$ \\
\hline
\end{tabular}

Fonte: PROJETO UNI MARILIA. Relatório de avaliação da fase de consolidação 20002001 (PROJETO, 2001).

O enfoque segundo disciplina mostrou haver uma ampliação progressiva da articulação básico/clínica ao longo do programa:

Figura 41 - Distribuição percentual das questões do EAC segundo disciplina nas quatro primeiras séries do curso de medicina da FAMEMA em 2001.

\begin{tabular}{|c|c|c|c|c|}
\hline Disciplina & $1^{\mathrm{a}}$ série & $2^{\mathrm{a}}$ série & $3^{\mathrm{a}}$ série & $4^{2}$ série \\
\hline Básica(s) & $49,0 \%$ & $3,4 \%$ & $23,7 \%$ & - \\
\hline Básica/clínica & $51,0 \%$ & $96,6 \%$ & $76,3 \%$ & $100,0 \%$ \\
\hline
\end{tabular}

Fonte: PROJETO UNI MARILIA. Relatório de avaliação da fase de consolidação 2000- 2001 (PROJETO, 2001).

Muito embora ainda existam limitações no desenvolvimento das unidades e no processo de avaliação, há uma preocupação muito grande em avançar na complexidade da abordagem dos temas e em buscar coerência entre as várias partes e ações do novo currículo e os objetivos gerais pretendidos com a proposta. No Fórum de Desenvolvimento Curricular de setembro de 2001, foi questionado se as unidades e os problemas de papel seriam de fato o cenário ideal para concretizar a integração das dimensões. Argumentou-se que, apesar de a prática nos cenários reais ser mais favorável a essa articulação, se não houvesse uma 
mudança na prática dos docentes e em sua maneira de abordar os assuntos, tampouco nesses outros cenários ocorreria a ampliação da clínica.

Foi proposta a criação de um grupo multidisciplinar para assumir a coordenação de cada ano, rompendo os "muros das unidades" e tornando possível trabalhar os conteúdos de toda a série de acordo com as diretrizes curriculares. Sugeriu-se também a ampliação da participação dos professores na definição dos conteúdos, bem como sua capacitação para ampliar sua compreensão acerca das dimensões psicológica e social: "o biopsicossocial é essencial; só deixou de existir porque a medicina deixou de cumprir o seu papel e nós docentes temos uma formação e uma prática deformadas, que precisam ser transformadas".

Vale ressaltar que essa orientação contraria os interesses e apreciações manifestados por parcela significativa dos estudantes. Consistentemente ao longo dos anos, em sua visão, as unidades educacionais melhor avaliadas são aquelas que privilegiam a dimensão biológica em detrimento das demais e que focalizam exclusivamente o atendimento clínico/individual de pacientes com patologias de maior complexidade. Embora predominante, não é essa a única posição entre os estudantes, havendo aqueles que defendem a necessidade de ampliação da clínica e expansão do modelo biomédico (PROJETO, 2001).

A avaliação dos estudantes em relação às várias unidades educacionais no ano 2001 está apresentada a seguir, série por série, expressada através da porcentagem de estudantes que consideram satisfatórias essas atividades. A metodologia utilizada será discutida no item Avaliação. 
Figura 42 - Distribuição percentual de conceito satisfatório atribuído pelos estudantes às unidades educacionais na $1^{\text {a }}$ série do Curso de Medicina da FAMEMA em 2001.

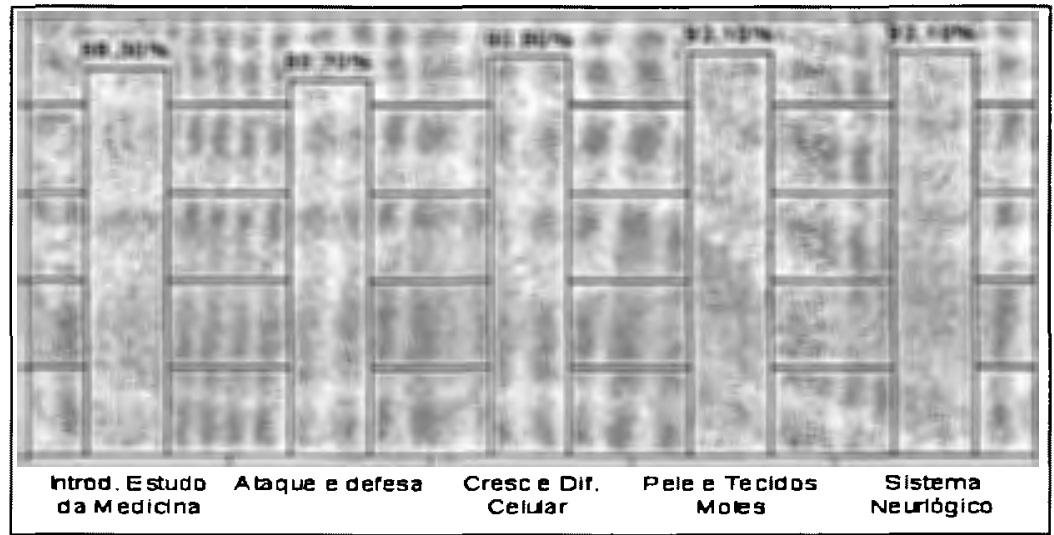

Fonte: PROJETO UNI MARÍLIA. Relatório de avaliação - fase de consolidação 2000-2001 (PROJETO, 2001).

Figura 43 - Distribuição percentual de conceito satisfatório atribuído pelos estudantes às unidades educacionais da 2" série do Curso de Medicina da FAMEMA em 2001.

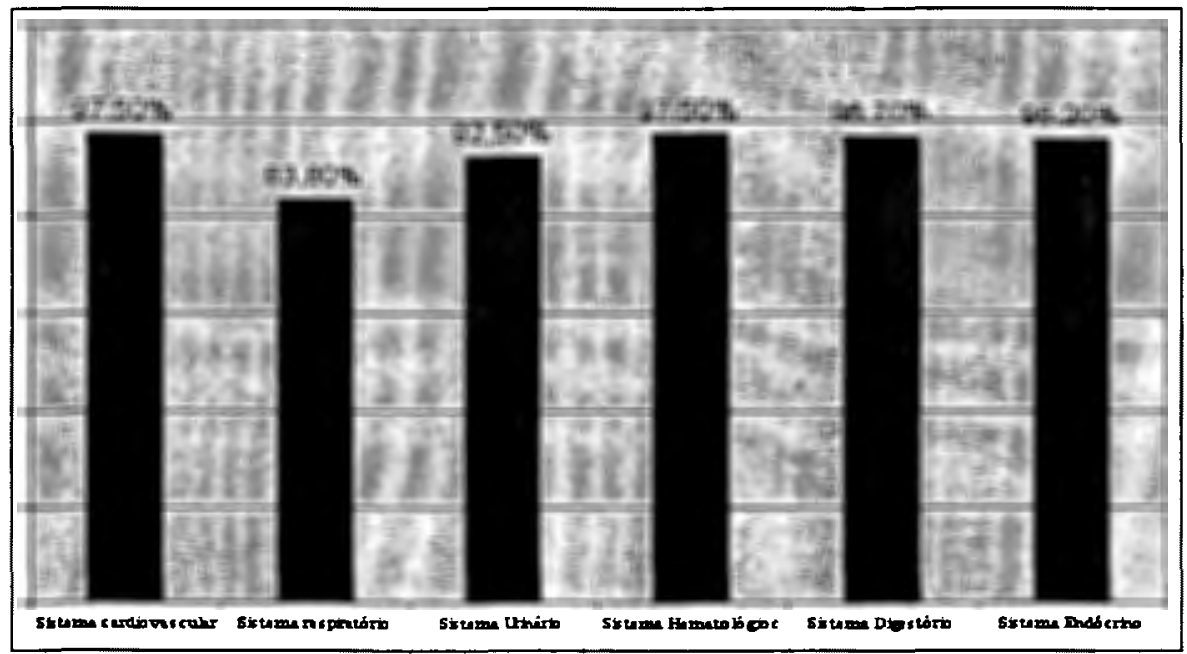

Fonte: PROJETO UNI MARÍLIA. Relatório de avaliação - fase de consolidação 2000-2001 (PROJETO, 2001). 
Figura 44 - Distribuição percentual de conceito satisfatório atribuído pelos estudantes às unidades educacionais na 3a série do Curso de Medicina da FAMEMA em 2001.

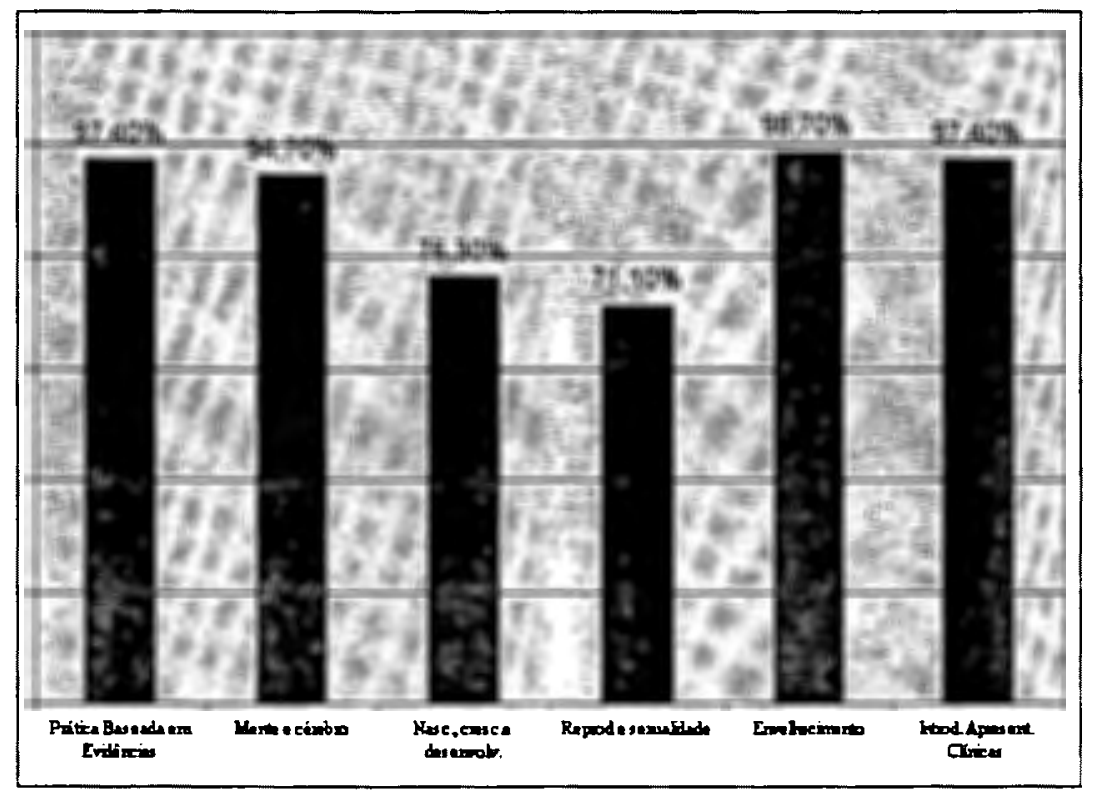

Fonte: PROJETO UNI MARÍLIA. Relatório de avaliação - fase de consolidação 2000-2001 (PROJETO, 2001).

Figura 45 - Distribuição percentual de conceito satisfatório atribuído pelos estudantes às unidades educacionais na $4^{2}$ série do Curso de Medicina da FAMEMA em 2001.

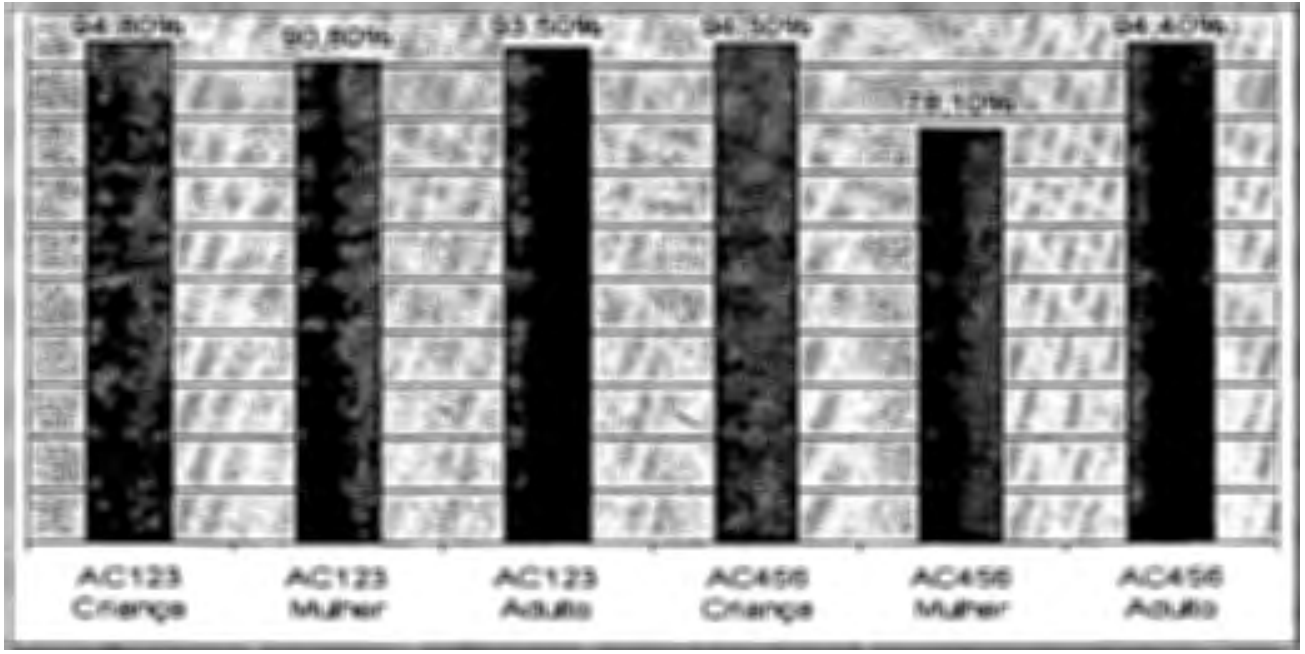

Fonte: PROJETO UNI MARÍLIA. Relatório de avaliação - fase de consolidação 2000-2001 (PROJETO, 2001). 
A dinâmica de avaliação permanente e de construção e reconstrução do currículo é coerente com a compreensão hoje predominante entre os docentes, de que o currículo deve estar em processo permanente de construção e que deve estar, cada vez mais, voltado às necessidades de aprendizagem dos estudantes.

Há algumas análises críticas a respeito da orientação curricular que vem sendo adotada na prática: o atual seria muito mais um currículo orientado por objetivos que realmente baseado em problemas (entrevistado M2). Outros docentes criticam a importância dada aos problemas de papel e propõem alternativas mais radicais de integração entre teoria e prática (grupo focal dos docentes).

Essas reflexões vêm junto com uma percepção das próprias limitações conceituais da proposta de aprendizagem baseada em problemas.

"Precisamos saber que essa foi uma proposta desenvolvida em 1969 por um grupo de docentes de medicina que nunca tinha lido Piaget, que nunca tinha trabalhado com educadores. Então há que identificar as potencialidades e também as limitações que o método apresenta" (entrevistado M2).

"Não estamos falando da Panacéia para o ensino da medicina. Estamos falando de uma proposta que avança muito em relação às concepções tradicionais, mas que ainda enfrenta limitações importantes" (entrevistado M2).

A interdisciplinaridade do ponto de vista da produção de conhecimentos ainda não conseguiu avançar de maneira significativa. Apesar de formalmente criados, os Grupos Interdisciplinares de Trabalho não adquiriram vida real. $O$ único GIT com perspectivas reais de se converter em produtor de conhecimento é o de Educação. Há também um grupo de professores que se agrupa em torno da Interação Comunitária, que tem potencial de desenvolver-se como grupo de investigação.

No primeiro grupo, já há 8 profissionais, com mestrado e doutorado na área de educação de profissionais de saúde, que estão profundamente dedicados ao 
estudo e à prática nesse terreno (entrevistado M5). No segundo grupo está havendo um trabalho intensivo de capacitação em metodologias de investigação e a construção de projetos de investigação sobre a realidade prática dos serviços de saúde (entrevistado M4).

O grande investimento feito na capacitação docente em Medicina Baseada em Evidências, que tinha também o objetivo de incentivar a prática de investigações pelo corpo docente, conseguiu até o momento mobilizá-los para o estudo e a aprendizagem permanentes, mas não para a investigação (entrevistados M2 e M3).

Há o desenvolvimento de investigações em alguns segmentos das áreas básicas (especialmente genética). Existe também um importante estímulo ao desenvolvimento da investigação pelos estudantes ao longo de todo o curso, especialmente no espaço da Interação Comunitária, que já começa a dar frutos significativo número de estudantes de Marília conquistou vagas no programa de bolsas para Investigação em Bioética que o Conselho Regional de Medicina de São Paulo está promovendo (Entrevistado M2).

Também tem sido significativa a presença de trabalhos produzidos - por docentes e estudantes - para apresentação em congressos nacionais e internacionais de educação médica (Entrevistado M2).

Vale a pena também destacar a evolução do número total de consultas empréstimos de monografias, periódicos e audiovisuais na Biblioteca da FAMEMA, já que ela ilustra a dinamicidade do processo de busca e construção do conhecimento que se instalou na instituição: 
Figura 46 - Total geral de consultas e empréstimos de monografias, periódicos e audiovisuais na Biblioteca da FAMEMA de 1996 a 2001.

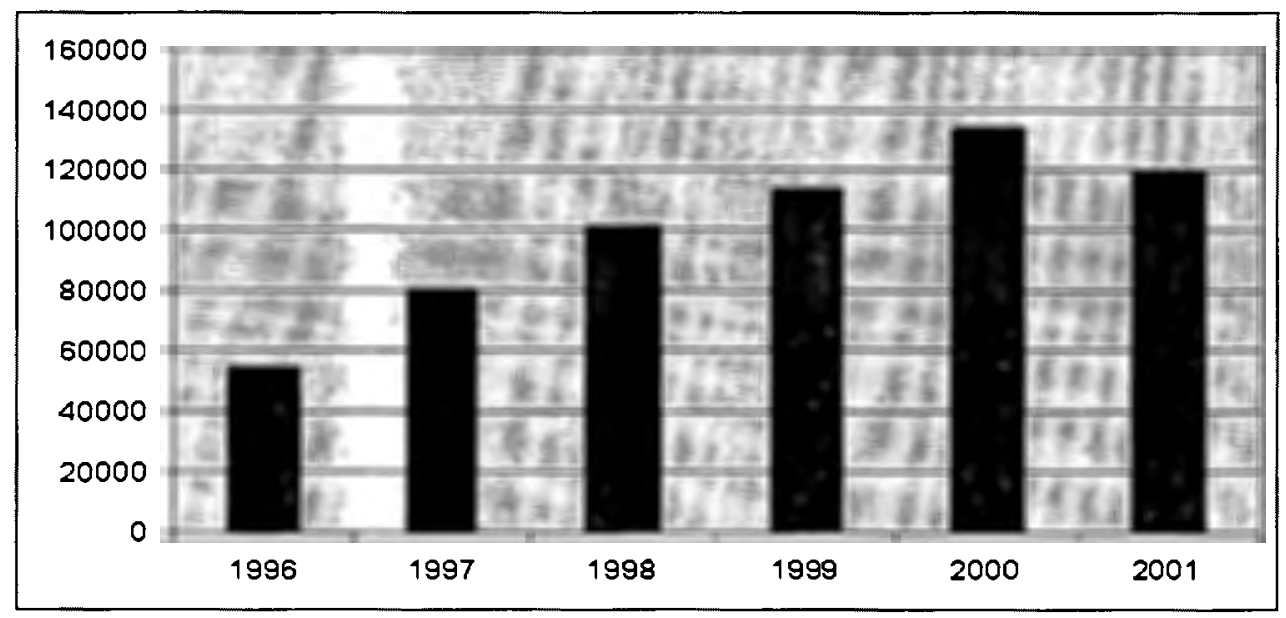

Fonte: PROJETO UNI MARILIA. Relatório de avaliação - fase de consolidação 2000- 2001, (PROJETO, 2001).

\subsubsection{Os cenários de aprendizagem e o conteúdo das práticas}

Os cenários de aprendizagem mantiveram-se os mesmos previstos na proposta original, embora a freqüência e o tipo de trabalho realizados na prática tenham sido modificados.

Vamos discutir especificamente a unidade de Interação Comunitária, a Unidade de Habilidades Profissionais e o Internato.

\subsubsection{A Interação Comunitária}

Nos primeiros anos de desenvolvimento a Interação Comunitária enfrentou grandes desafios teórico-conceituais e metodológicos. Dando seqüência ao trabalho realizado no PIMEC (experiência que havia sido de curta duração), inicialmente experimentou-se a idéia de trabalhar sobre os problemas da realidade, utilizando a metodologia da problematização. 
Os cenários privilegiados de trabalho dos estudantes eram dez Unidades Básicas de Saúde e suas respectivas áreas de abrangência. Pretendia-se que cada grupo de estudantes permanecesse na mesma área ao longo dos 4 anos do curso, possibilitando não só melhor conhecimento da área, como o estabelecimento de vínculos com a população e com os profissionais ali fixados.

Nos dois primeiros anos de implementação (1997 e 1998), a IC enfrentou uma série de problemas: alguns "intrínsecos" à IC e outros "extrínsecos". Os problemas "intrínsecos" diziam respeito a dilemas metodológicos e contextuais da própria construção da unidade. Os problemas "extrínsecos" tinham a ver com o lugar da IC dentro da proposta político-pedagógica da instituição e com sua relação com os dois cursos - medicina e enfermagem.

Os problemas intrínsecos nesse período eram:

a) o ator comunidade organizada não estava presente para fazer ouvir sua voz na identificação de problemas relevantes na área de abrangência de cada unidade de saúde (Entrevistado M4);

b) o ator serviços de saúde passava então a ocupar o papel de único interlocutor dos grupos de estudantes e docentes. Assim sendo, suas idiossincrasias repercutiam de maneira importante nas possibilidades de trabalho dos estudantes. Apesar do longo investimento na transformação do modelo de atenção, as práticas de prevenção a doenças e de promoção à saúde não estavam organizadas de maneira sistemática nas unidades, dificultando a inserção dos estudantes na ação prática (SILVA, 2000); (OFICINA, 1998);

c) apesar de a proposta ser trabalhar com a problematização da realidade, havia muita insegurança dos docentes em trabalhar com problemas tão desestruturados como os que se apresentavam nos cenários reais (SILVA, 2000);

d) havia a tendência de considerar que "os estudantes não estavam prontos para a ação" e se prolongava muito a fase da teorização, reduzindo 
excessivamente o tempo e as possibilidades de ação prática (OFICINA, 1998).

Os problemas "extrínsecos" eram:

a) apesar de haver uma decisão institucional a respeito da importância fundamental da IC dentro das novas propostas curriculares, a principal energia do grupo gestor era gasta na construção das unidades verticais e na implementação das tutorias. A tarefa de construir a IC, portanto era assumida por um grupo muito restrito de pessoas e em alguns momentos chegou a ser uma tarefa solitária da própria coordenação da unidade (SILVA, 2000);

b) havia uma separação radical entre a IC e os conteúdos e atividades que estavam sendo trabalhados nas outras atividades educacionais verticais do curso de medicina (OFICINA, 1998);

c) havia uma tendência a restringir os conteúdos e práticas da Interação Comunitária ao âmbito da Saúde Coletiva (OFICINA, 1998);

d) havia reticências do curso de enfermagem em relação à adesão à idéia da IC, já que se considerava que os conteúdos e práticas que poderiam ser concretizados nesse espaço já estariam contemplados em outros momentos de seu currículo; portanto investiam muito pouco em sua construção e viabilização (entrevistado M4).

Buscaram-se várias alternativas e recursos para enfrentar esses problemas (especialmente os intrínsecos). Planejamento estratégico como ferramenta para poder tomar decisões mais precisas em relação ao tema a ser trabalhado. Eleição de temáticas de trabalho que estivessem já na pauta de ação das unidades de saúde (bebê de risco, hipertensão, saúde da mulher) para diminuir a taxa de desestruturação. Capacitação intensiva dos docentes em dinâmicas de grupo e outras temáticas relevantes. Muito esforço e pequenos resultados. 
Em 1999, quando os serviços de saúde começaram a adquirir personalidade própria e a estabelecer uma intensa dinâmica própria de construção, houve conflitos, pois em determinados momentos o processo de planejamento do trabalho da IC não estava incluindo o parceiro "serviços", como originalmente planejado, e em outros momentos havia diferenças de tempos e de necessidades que tornavam difícil a articulação.

Finalmente, quando o município adotou a estratégia de saúde da família, surgiu um cenário mais favorável, menos inseguro e mais estruturante para a Interação Comunitária.

Numa oficina de sistematização do projeto UNI surgiu a proposta de levar os elementos centrais da estratégia de saúde da família também para as unidades básicas, de modo a cumprir dois objetivos de uma só vez: ampliar os espaços disponíveis para o trabalho dos estudantes na lógica da saúde da família (já que inicialmente não havia número de equipes suficiente para a inserção de todos os estudantes) e estimular a adoção de novas práticas sanitárias em todos os espaços de prestação da atenção básica (OFICINA, 1998).

A secretaria demorou um pouco mais que a faculdade para assumir a idéia, o que obrigou a novas adaptações, mas já agora num outro patamar de elaboração e de governabilidade.

Os dois eixos centrais da Interação Comunitária atualmente são a saúde da família e a investigação científica.

Instrutores e estudantes foram capacitados em saúde da família através do módulo introdutório usualmente oferecido para os profissionais que ingressam no programa. Desde o $1^{\circ}$ ano os estudantes são divididos por área de abrangência das unidades e estabelecem vínculos com população e profissionais com quem vão trabalhar ao longo de 4 anos.

Com os estudantes do primeiro ano trabalha-se, conjuntamente com os profissionais das unidades, com o objetivo de construir as bases para uma prática mais ativa e ampliada, dando oportunidade a que conheçam as diferenças entre as 
propostas e as práticas realizadas nas unidades básicas e nas unidades de saúde da família, para entender a participação social e a relação dos profissionais de saúde com a família. Os estudantes participam ativamente dos trabalhos de diagnóstico local, cadastramento de famílias, identificação de problemas, articuladamente com as equipes locais. Além disso, têm como tarefa a realização de uma investigação científica (um estudo descritivo) sobre algum aspecto relevante do diagnóstico de saúde realizado na área (FACULDADE, 2001b).

Com o segundo ano, o trabalho tem como objetivo contribuir para a melhoria da atenção à saúde de famílias através da implementação de ações prioritárias de prevenção e promoção à saúde, identificadas em conjunto com os gestores do sistema, profissionais das unidades e com a comunidade. Os estudantes também dão continuidade ao trabalho de investigação científica iniciado no ano anterior: focalizam dados em relação ao problema identificado, analisam os instrumentos disponíveis nos serviços para a identificação das ações prioritárias, cadastram indivíduos, constroem banco de dados etc. E elaboram um trabalho, agora individual, no qual já estabelecem comparações, caracterizando ainda melhor o problema abordado (FACULDADE, 2001c).

O terceiro ano, em 2001, deu continuidade ao trabalho que era feito em torno de Hipertensão Arterial e Atenção às Gestantes, construindo ativamente propostas de ações educativas no plano da prevenção e da promoção à saúde. $O$ trabalho científico proposto foi a análise da maneira como um programa de atenção específico (Atenção aos Hipertensos ou Pré-Natal) é desenvolvido naquela unidade específica e também no restante do município (FACULDADE, 2001d).

Do $1^{\circ}$ ao $3^{\circ}$ ano, os estudantes estão somente um período por semana nas unidades de saúde. No $4^{\circ}$ ano já são 4 períodos semanais de prática ao longo de todo ano (as sessões de tutoria, agora de Apresentações Clínicas, foram reduzidas a uma por semana e, como já mencionado, os profissionais da Saúde da Família trabalham como co-tutores nesse grupos). 
Em 2001 ainda não havia equipes de saúde da família suficientes para receber todos os estudantes, então, houve um rodízio - eles ficam 18 semanas inseridos no trabalho de uma UBS e outras 18 semanas em uma Unidade de Saúde da Família (mas a proposta no futuro é que todos os alunos possam se inserir em equipes de saúde da família).

Os estudantes participam de todas as atividades que são realizadas pela equipe local sob a orientação de um profissional dos serviços e supervisão semanal de um docente. Na linha da investigação científica estão encarregados de realizar um estudo de caso e realizar trabalho de evento sentinela com os casos de óbito de pacientes da área que hajam sido internados (FACULDADE, 2001e).

Com essas novas diretrizes a Interação Comunitária adquiriu consistência interna e maior aceitação junto aos estudantes.

"Antes havia rejeição dos alunos em relação à Interação Comunitária - que era chamada de "Chateação" Comunitária - um pouco porque havia problemas na implementação da proposta e outro pouco porque uma boa parte dos alunos da medicina tinham uma visão muito elitista de seu futuro profissional e não estavam interessados em ir para as unidades básicas e para a comunidade - mas agora parece que a coisa está mudando" (Grupo focal dos profissionais dos serviços e representantes da comunidade $\mathrm{M})$.

"No ano passado os alunos do primeiro ano fizeram o cadastro das familias, como se fossem agentes comunitários, em uma área e abrangência de uma UBS em que ainda não havia saúde da familia. Este ano nós tivemos que mudar a equipe da unidade do lugar e os estudantes concordaram em seguir junto com a equipe, mas "amarraram" com a outra turma de estudantes uma série de compromissos: que eles iam ter que ir cuidar do seu João, da dona Maria etc. Eles conheciam as pessoas pelos nomes, conheciam seus problemas, tinham estado por lá à noite, nos finais de semana, com um compromisso muito interessante" (Grupo focal dos profissionais dos serviços e representantes da comunidade $\mathrm{M}$ ). 
"A partir de um determinado momento o aluno começa a aceitar melhor a Interação, tipo pelo terceiro ano" (Grupo focal dos profissionais dos serviços e representantes da comunidade $\mathrm{M}$ ).

"A satisfação que o trabalho no PSF dá em termos de vínculos com a população, de respeito e de resultados é muito grande e reflete numa mudança de atitude e de compromisso dos profissionais. Os alunos percebem isso. Eles vão no mesmo barco" (Grupo focal dos profissionais dos serviços e representantes da comunidade $M$ ).

"Parece também que os alunos que hoje em dia vêm estudar aqui na FAMEMA já são diferentes: eles sabem muito bem onde estão entrando. Tanto em relação ao método de ensino como em relação a esse compromisso com a comunidade" (Grupo focal dos profissionais dos serviços e representantes da comunidade $\mathrm{M})$.

Embora a avaliação dos estudantes sobre as atividades realizadas na IC tenha progressivamente melhorado desde 1997, a abordagem coletiva ainda encontra muita resistência. Muitos dos estudantes de medicina consideram haver irrelevância do conteúdo da unidade para a formação médica.

A avaliação dos estudantes melhora sensivelmente na IC4 (4 $4^{\text {a }}$ série), uma vez que o enfoque do cuidado nas Unidades Básicas de Saúde prioriza o atendimento individual, centrado no médico. Por outro lado, quando esses estudantes passam pelas Unidades da Saúde da Família (nas quais há concretamente maiores possibilidades de realizar ações de promoção e prevenção), uma grande parcela ainda não reconhece esses desempenhos como apropriados para o trabalho médico.

Apesar dessas dificuldades, os estudantes reconhecem que:

"a IC é a unidade que favorece a inserção do estudante na realidade do trabalho na saúde" (grupo focal dos estudantes $\mathrm{M}$ ).

"Começou a ficar legal (a IC) no segundo semestre do ano passado e agora este semestre eu estou gostando. Antes a gente ficava sentado numa mesa discutindo o que é familia, enrolando... Mas depois a gente fez cadastro de 
familia (...) Tem uma familia que é uma história trágica (...) A gente vai lá, já fez um plano para a mãe que é hipertensa, agora está agilizando a aposentadoria de um dos filhos deficientes para ver se aumenta a renda da familia. Então eu adoro! E a gente tá aprendendo a cuidar de hipertensão, como é o protocolo, como se deve tratar e tal. Isso é muito legal nesse método" (grupo focal dos estudantes M).

O resultado da avaliação quantitativa da Interação Comunitária pelos estudantes é mostrado na próxima figura :

Figura 47 - Distribuição percentual de conceito satisfatório atribuído pelos estudantes à unidade de Interação Comunitária da $1^{*}$ à $4^{\boldsymbol{a}}$ série dos Cursos de Medicina e Enfermagem da FAMEMA em 2001.

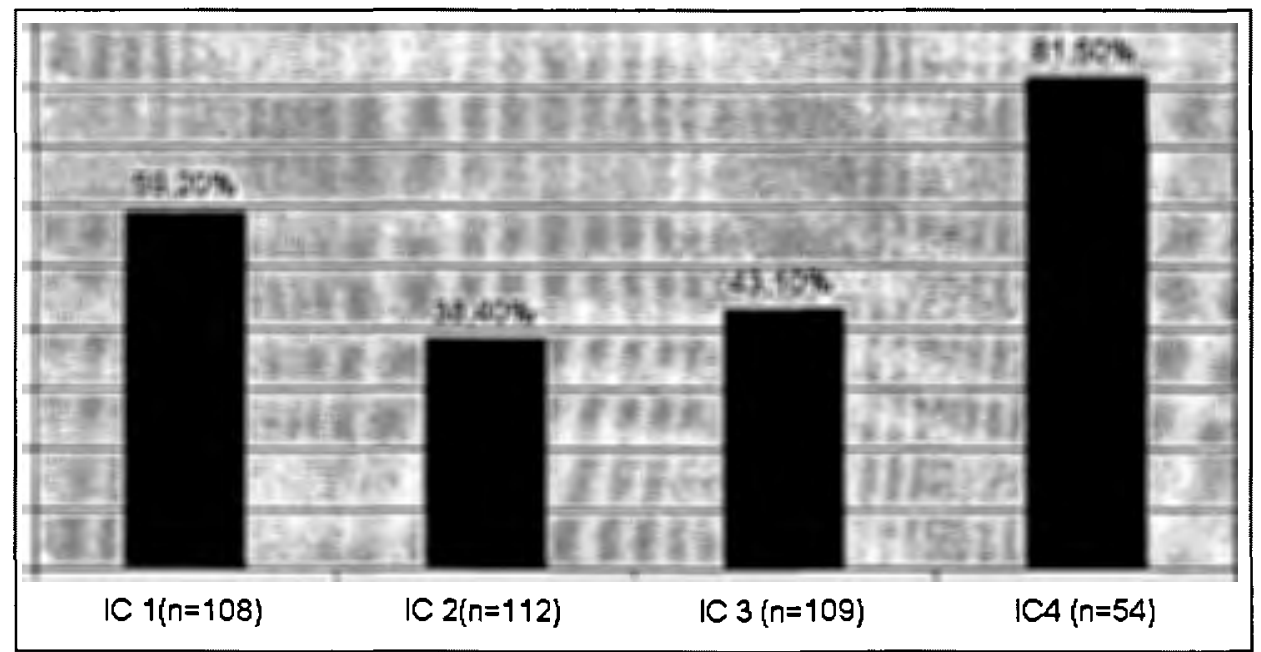

Fonte: PROJETO UNI MARILIA. Relatório de avaliação fase de consolidação 2000-2001 (PROJETO, 2001).

Agora a IC também é vista como um espaço estratégico dentro do curso: muitos atores identificam que há potencial de que nesse espaço a articulação entre as dimensões biológica, psicológica e social possa se dar de maneira cabal (Entrevistados M1, M2, M3) (FORUM, 2001).

Mas, para tanto, a IC não pode continuar correndo "em paralelo": é necessário construir pontes entre os três eixos do currículo. Com as Habilidades 
Profissionais, as possíveis conexões são mais evidentes: o cenário e os atores trabalhados na IC poderiam também ser o espaço do desenvolvimento das habilidades na prática. No entanto, com as unidades verticais as possibilidades de articulação não são tão claras, pois seu desenho por sistemas e seu tempo de duração limitado não ajudam na construção de interconexões com um espaço de prática necessariamente mais desestruturado (entrevistado M4).

\subsubsection{As habilidades profissionais}

O programa de desenvolvimento das habilidades profissionais para a primeira turma do novo currículo só foi introduzido a partir do segundo ano. Isso aconteceu por razões operacionais - o grupo gestor avaliou que não haveria condições práticas de enfrentar mais esse desafio, ao mesmo tempo em que trabalhavam na implantação das unidades e da IC e na conquista de apoio político para mudança. Para as turmas seguintes, as Habilidades foram introduzidas desde o primeiro ano.

Houve também várias dificuldades nesse campo. Primeiro porque a equipe que "naturalmente" se encarregou da tarefa - a responsável pela Semiologia no currículo anterior - tinha muitas dificuldades técnicas e conceituais para trabalhar a proposta de maneira satisfatória. Segundo, porque as habilidades começaram a ser desenvolvidas como uma linha independente, sem conexões com as unidades verticais: então um aluno estava estudando sistema nervoso nas unidades verticais e aprendendo semiologia do aparelho respiratório (entrevistado M1); (PROJETO, 2001).

Através de uma intervenção direta do grupo gestor essa desintegração foi resolvida e os conteúdos passaram a ser definidos e trabalhados de maneira articulada (PROJETO, 1999).

A unidade passou a ter como objetivo trabalhar a relação e a interação interpessoal como bases da prática médica, buscando instrumentalizar os 
estudantes para o reconhecimento das situações de saúde e para a definição das possibilidades e alternativas de intervenção visando a qualidade de vida.

A partir dessa ampliação da concepção acerca do que seriam as habilidades, os campos da comunicação e do desenvolvimento do raciocínio clínico ganharam destaque. Uma assessoria especial foi designada para acompanhar o trabalho e a equipe responsável ficou dividida em duas: uma, basicamente composta por clínicos, ficou responsável pelas habilidades clínicas e outra, basicamente composta por profissionais da área $\mathrm{psi}$, responsável pelas habilidades de comunicação. Essa fragmentação persiste até o presente momento.

Na primeira série, o objetivo fundamental das habilidades comunicacionais está no campo da comunicação com os colegas, com outros profissionais, com os clientes e seus familiares. Na área da semiologia, o objetivo é o exame físico normal (PROJETO, 1999).

Na segunda série, exame físico normal e alterado e habilidades de comunicação para desenvolver uma entrevista de forma empática (PROJETO, 1999).

$\mathrm{Na}$ terceira série, técnicas de anamnese, exame físico normal e alterado, raciocínio clínico e solução de problemas, além das habilidades de comunicação para a interação ética com os clientes no desenvolvimento de todas essas atividades.

Se o desafio da integração com as unidades verticais foi vencido, ainda persiste o da integração das Habilidades Profissionais com a Interação Comunitária. Atualmente todas as atividades práticas das habilidades são desenvolvidas nos laboratórios de simulação e nas enfermarias. Reconhece-se, no entanto, que essa aproximação "favoreceria o realismo no desenvolvimento das habilidades profissionais" (PROJETO, 2001).

Ainda há muitas reclamações dos estudantes especialmente em relação à heterogeneidade dos instrutores de semiologia: 
"Tinha um professor, que não é que ele fosse contra o PBL, ele simplesmente não conseguia trabalhar daquele jeito. O grupo dele chegava, sentava e o semiologista ficava falando..." (grupo focal dos estudantes $\mathrm{M}$ ).

"Precisa uniformizar mais os profissionais, os instrutores semiologistas, porque cada um está trabalhando de um jeito e isso é ruim" (grupo focal dos estudantes $\mathrm{M})$.

Mas já se reconhecem aspectos positivos e a evolução favorável:

"mas eu acho que de uns tempos para cá tem melhorado. Na sua época a semiologia começou no segundo ano. Para nós já começou no primeiro e isso é uma grande oportunidade de ficar grandes periodos trabalhando e se habituando...desde o primeiro ano, quando você não sabe nada e tudo é novidade...vai ganhando segurança" (grupo focal dos estudantes $\mathrm{M}$ ).

"o que é legal é que a gente vai estudando semiologia junto com as outras coisas" (grupo focal dos estudantes $\mathrm{M}$ ).

A avaliação quantitativa da unidade de Habilidades Profissionais pode ser vista na figura 48:

Figura 48 - Distribuição percentual de conceito satisfatório atribuído pelos estudantes às unidades de Habilidades Profissionais em Semiologia e Comunicação da $1^{\mathrm{a}}$ à $4^{\mathrm{a}}$ série do Curso de Medicina da FAMEMA em 2001.

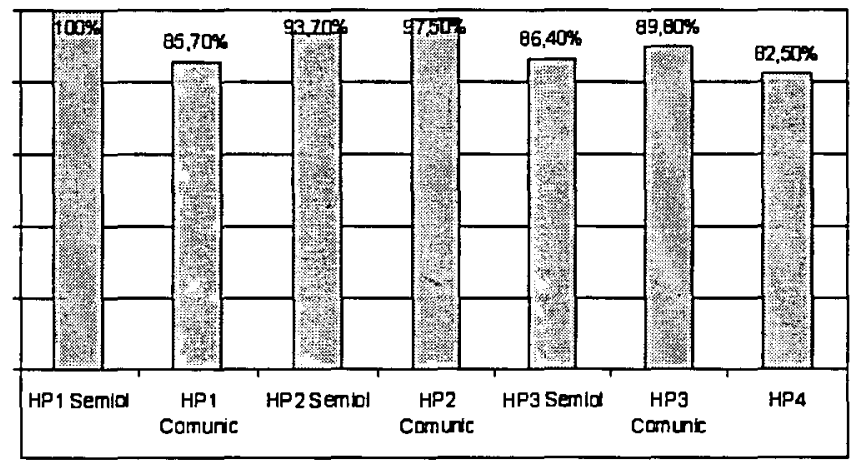

Fonte: PROJETO UNI MARILIA. Relatório de avaliação da fase de consolidação 2000-2001(PROJETO,2001). 


\subsubsection{O internato}

As formulações iniciais relativas ao internato $\left(5^{\circ}\right.$ e $6^{\circ}$ anos do curso de medicina) não implicariam maiores mudanças metodológicas, já que o trabalho dos estudantes já se dava em pequenos grupos e era orientado pela proposta de aprendizagem com base na prática. Previa-se somente mudança nos cenários de ensino-aprendizagem, especialmente no $5^{\circ}$ ano, que era definido como um "externato", pois o trabalho dos estudantes nas áreas de Saúde do Adulto e Saúde Materno-Infantil seria feito primordialmente em unidades de primeiro e segundo níveis, ficando para o $6^{\circ}$ ano o trabalho nas enfermarias e unidades de emergência do hospital terciário (KOMATSU et al, 1998).

No entanto, ao longo da implementação da nova proposta, a compreensão sobre o internato foi mudando substancialmente.

Em primeiro lugar, reconheceu-se a importância de ampliar os espaços de prática em espaços "reais" ao longo dos 4 primeiros anos do curso - originalmente previa-se apenas um período semanal de prática na Interação Comunitária.

A proposta de organizar a $4^{\text {a }}$ série em Apresentações Clínicas possibilitou ao mesmo tempo resolver uma série de problemas:

- construir as Apresentações Clínicas incluindo os temas relevantes como reza sua definição - mas também cobrindo eventuais vazios identificados através da análise dos conteúdos efetivamente abordados nas três séries anteriores;

- reduzir o tempo destinado às discussões teóricas e ampliar o tempo destinado às práticas em cenários reais

- articular cada uma das unidades de Apresentações Clínicas com o trabalho na Interação Comunitária, avançando na superação da dissociação entre teoria e prática existente nos anos anteriores

- ampliar efetivamente a participação dos profissionais dos serviços na construção e implementação do novo currículo para além da Interação 
Comunitária através da participação dos profissionais da saúde da família como co-tutores das unidades de Apresentação Clínica

O $4^{\circ}$ ano, com uma carga de atividades práticas de 16 horas semanais, converteu-se, portanto, no externato, antecipando a mudança que se havia planejado para a $5^{\text {a }}$ série.

Já havia amadurecido a compreensão de que para conseguir atingir os objetivos propostos para a FAMEMA, de propiciar uma formação integral e humanizada, respeitando a autonomia dos pacientes e levando em conta suas condições de vida e trabalho, seria necessário promover mudanças substanciais na prática clínica realizada por docentes e estudantes em todos os âmbitos e, principalmente, no Hospital das Clínicas (entrevistados M1, M2 e M3).

Retomando a idéia da clínica ampliada, foi proposta uma reorganização inicialmente das enfermarias. Propôs-se uma mudança da lógica da organização do trabalho: que ele fosse estruturado de acordo com as necessidades dos pacientes e não de acordo com a lógica das especialidades.

As enfermarias deixariam de ser clínicas ou cirúrgicas, pediátricas ou obstétricas. Passariam a ser enfermarias, cujos leitos estariam sob a responsabilidade de equipes nucleares compostas no caso da saúde do adulto por um clínico e um cirurgião e no caso da saúde materno-infantil por um pediatra e um ginecologista. A essa dupla seriam ainda agregados enfermeiros, auxiliares de enfermagem, além, é claro, dos estudantes do quinto ano de medicina e do quarto ano de enfermagem.

Essa equipe seria responsável pelos cuidados integrais aos pacientes que fossem internados nos leitos sob sua tutela, desde a sua admissão até seu acompanhamento ambulatorial e posterior encaminhamento para a rede básica de serviços de saúde. De acordo com as necessidades específicas de cada caso, seriam solicitados auxílio e participação dos demais especialistas, que entrariam na cobertura dos vários casos de acordo com uma lógica matricial. 
Diante das dificuldades de concordância e adesão, até mesmo dentro do grupo gestor, optou-se por restringir essas mudanças às enfermarias de retaguarda da emergência. E assim foi iniciado o internato em janeiro de 2001.

Depois de muitos e sérios conflitos (gerados pela resistência dos profissionais - os especialistas pela perda de espaço, os especialistas das áreas básicas pelo aumento do trabalho e da responsabilidade, os residentes porque perdiam sua primazia dentro da enfermaria), chegou a existir um período de acomodação e de bom funcionamento da nova dinâmica (entrevistados M1, M2 e $\mathrm{M} 3)$.

Diante, no entanto, de novas pressões, o grupo gestor recuou e o hospital voltou a funcionar praticamente de acordo com o esquema anterior - enfermarias de saúde do adulto divididas em leitos clínicos e cirúrgicos etc. Algumas equipes conseguiram ser preservadas e um embrião - de novas dinâmicas e relações entre profissionais e entre as equipes e os pacientes - está em operação (entrevistado M1); (PROJETO, 2001).

Para o ano de 2002, pela primeira vez existe um manual para o internato. E há alguns elementos interessantes no sentido da ampliação da clínica indicados, por exemplo, nos "Sete princípios do ensino-aprendizagem", quando se sugere ao preceptor que utilize questões para estimular os estudantes: 
Figura 49. Questões para estimular a articulação das várias dimensões do processo saúdedoençano internato do curso de medicina da FAMEMA em 2002.

\begin{tabular}{|c|c|}
\hline de questōes & Exemplos \\
\hline Questões abertas & $\begin{array}{l}\text { Quais são suas impressões sobre o paciente/ou caso? Quais aspectos do } \\
\text { problema foram de maior interesse para você? Por onde poderemos } \\
\text { começar? }\end{array}$ \\
\hline Questōes diagnósticas & $\begin{array}{l}\text { Qual a sua análise do problema? Quais os diagnósticos diferenciais? Que } \\
\text { conclusões você pode tirar dos dados obtidos? }\end{array}$ \\
\hline $\begin{array}{l}\text { Questões solicitando } \\
\text { informações atuais: }\end{array}$ & $\begin{array}{l}\text { Qual o resultado do hemograma? Qual a dose de digoxina? Já temos o RX } \\
\text { de tórax? }\end{array}$ \\
\hline $\begin{array}{l}\text { Questōes solicitando } \\
\text { informações } \\
\text { pregressas: }\end{array}$ & $\begin{array}{l}\text { Por que este paciente adoeceu? Qual o programa de atenção primária que } \\
\text { ele estava freqüentando? Qual a aderência do paciente ao plano de } \\
\text { cuidados que havia sido instituído para ele? Quais os motivos da não } \\
\text { aderência? }\end{array}$ \\
\hline Questões estimulantes & $\begin{array}{l}\text { A sua conclusão está baseada em que evidências? Quais argumentos } \\
\text { poderiam ser levantados contra a sua conclusão? Qual a hipótese ou } \\
\text { diagnóstico mais provável? }\end{array}$ \\
\hline \begin{tabular}{|l|}
$\begin{array}{l}\text { Questões } \\
\text { requerem ação: }\end{array}$ \\
\end{tabular} & $\begin{array}{l}\text { O que precisa ser feito para implementar um plano de tratamento para } \\
\text { este paciente? Que recursos da comunidade precisamos encontrar? }\end{array}$ \\
\hline \begin{tabular}{|l|} 
Questões \\
prioridade/seqüência:
\end{tabular} & $\begin{array}{l}\text { Diante do paciente com recursos limitados: qual o primeiro passo a ser } \\
\text { dado? Qual o segundo? }\end{array}$ \\
\hline Questões prognósticas & $\begin{array}{l}\text { Se suas conclusões são apropriadas, qual sua expectativa para os próximos } \\
\text { meses ou anos? O paciente vai conseguir executar a prescrição } \\
\text { recomendada? Onde e quem vai seguir este paciente? Que recursos da } \\
\text { comunidade estarão disponiveis? }\end{array}$ \\
\hline Questões hipotéticas & $\begin{array}{l}\text { Se o teste da função hepática for normal, como isso vai afetar seu plano de } \\
\text { tratamento? Como uma história familiar de coronariopatia alteraria seu } \\
\text { raciocínio? }\end{array}$ \\
\hline Questões de extensão & $\begin{array}{l}\text { Quais são as implicações de suas conclusões para o tratamento da asma } \\
\text { entre crianças da escola primária dessa comunidade? }\end{array}$ \\
\hline $\begin{array}{l}\text { Questões } \\
\text { integração } \\
\text { biopsicossocial }\end{array}$ & $\begin{array}{l}\text { Como as condições de trabalho influenciaram o processo atual? Quais as } \\
\text { implicações psicológicas e sociais do processo atual? }\end{array}$ \\
\hline Questões gerais & $\begin{array}{l}\text { Baseado na sua experiência e nos estudos de incidência de gravidez em } \\
\text { adolescentes, qual a melhor estratégia para os professores e conselheiros } \\
\text { de nossas escolas? }\end{array}$ \\
\hline
\end{tabular}

Fonte: Manual do Internato 2002. (TSUJI \& ZANOLLI, 2002)

Também só para o ano de 2002 é que foi possível definir critérios para avaliação do estudante, do preceptor e do estágio. A avaliação do estudante passou a focalizar o desempenho realizado (comparado a um critério de satisfatório) segundo áreas de competência. Todas as áreas de competência têm o mesmo peso na avaliação final do estudante, embora a área de atitudes profissionais apresente o critério mais rigoroso (PROJETO, 2001). 
Os estudantes do quinto ano em 2001 referiram sentir-se angustiados com a nova fase de trabalho:

"é dificil porque a gente se sente culpada, não tem como. Mas o tempo todo tem que lidar com o que você acha que tem que saber. A gente tem que aprender a não se exigir demais também. Para a nossa turma foi mais complicado porque foi a primeira. Então a gente sempre acha que tem que saber mais do que sabe e nunca está totalmente seguro do que sabe" (grupo focal de estudantes $M$ ).

No entanto, apesar de muito ansiosos por não saberem avaliar suas competências, reconhecem vantagens decorrentes do tipo de formação que receberam:

"Era unânime os professores falarem que a gente tinha uma visão muito mais geral das coisas e uma capacidade de raciocínio mais rápido" (grupo focal dos estudantes $M$ ).

"e foi engraçado perceber que durante todo esse periodo a gente tinha achado maçante esse negócio de psicossocial. Achávamos que não ia adiantar nada na hora da prática. Mas na hora que se fala na prática, enfermaria e ambulatório, faz diferença. Mesmo inconscientemente você lembra que tem que tratar o paciente com um minimo de dignidade" (grupo focal dos estudantes $M$ ).

“Uma colega minha que estava passando no pronto-socorro atendeu um paciente com uma sutura para fazer. Sutura, simples sutura...não se sabia a hora em que o ferimento tinha ocorrido e nem se havia sido provocado por algum objeto de ferro...Aí ela achou estranho porque era um paciente jovem e ele falou que havia caido no banheiro e acordado com o queixo sangrando. Ai ela achou estranho e foi conversar com a professora, que disse que provavelmente ele havia bebido. Ela perguntou se ele bebia e ele negou. Ela voltou para a professora e acabou pedindo um eletro. Quando chegou o eletro, tinha lá um bloqueio congênito, que geralmente não leva a nenhuma sintomatologia, provoca diretamente morte súbita. Ou seja, ele saiu do pronto-socorro direto para a Santa Casa para implantar um marca-passo permanente. Esse virou o acontecimento do dia no Pronto-Socorro $E$ eu 
tenho certeza de que se não fosse a visão integrada, ela não teria conseguido ler nas entrelinhas do que o paciente dizia" (grupo focal dos estudantes M).

Com o processo de educação permanente instituído no ano 2002 para os preceptores do internato, espera-se ser possível avançar na reflexão crítica, na transformação das práticas e assim conquistar apoio para voltar a implementar a reformulação do funcionamento do hospital e avançar na clínica ampliada.

No entanto, ficou claro pelas reações dos residentes, que será muito difícil reorganizar o funcionamento do hospital e do internato sem transformar também a lógica da Residência Médica. Assim, começam a se deparar com a necessidade de repensar a formação médica como um todo (entrevistado M1).

\subsubsection{A Avaliação}

Muito embora existisse uma proposta bem definida e consistente de avaliação, a implementação prática das várias metodologias levou rapidamente à proposição de mudanças. Ao final do segundo ano de implantação houve uma profunda reformulação do processo de avaliação, com a produção de um Caderno de Avaliação (LIMA et al, 1999), que apresentava de maneira sistemática os princípios e os documentos/instrumentos utilizados para a avaliação formativa dos estudantes, docentes e unidades e para a avaliação somativa dos estudantes.

Apesar de parecerem óbvios, alguns princípios gerais foram reafirmados, pois a prática havia levado a um certo distanciamento e a muitas críticas dos estudantes:

- o desempenho deve ser medido de acordo com os objetivos de aprendizagem

- em todas as etapas do curso a avaliação deve estar baseada nos objetivos pré-estabelecidos para cada unidade educacional e para o ano letivo 
- os objetivos do programa devem orientar a construção dos objetivos das unidades educacionais e conseqüentemente da avaliação de processo e dos resultados obtidos (LIMA et al,1999).

Também foi destacada a importância de quatro conceitos centrais para a escolha dos métodos de avaliação:

- realismo: a capacidade do método simular o desempenho tal como este ocorreria em situações da vida real;

- abrangência: a capacidade do método verificar os múltiplos aspectos envolvidos na aprendizagem (conhecimento, habilidades, atitudes), utilizando uma variedade de fontes integradas;

- factibilidade: tempo consumido para elaboração, aplicação e correção dos métodos;

- julgamento: objetividade e subjetividade na correção (LIMA et al, 1999).

\subsubsection{A avaliação do estudante}

No terceiro ano da implantação, pretendeu-se ampliar e diversificar os instrumentos utilizados para a avaliação somativa dos estudantes e foram introduzidos novos formatos, que incluíam Exercício de Avaliação Cognitiva, Exercício Baseado em Problema, Exercício de Investigação Científica, Exercício de Problema à Monografia, OSCE, Mini-ISCE a depender das atividades que estivessem sendo avaliadas.

No entanto, essa multiplicidade de instrumentos dificultava o controle de qualidade dos exercícios e tornava muito lento o processo de devolução das informações, comprometendo a construção dos planos de recuperação dos estudantes.

Foi então adotada uma sistemática intermediária, que inclui:

- os formatos 3 e 6 que servem para a avaliação de desempenho nas sessões 
de tutoria, nas atividades educacionais das unidades longitudinais e na prestação de cuidado ao paciente

- exercício de avaliação cognitiva, que é constituído por 4 a 5 problemas que servem para contextualizar 12 a 15 questões escritas sobre o conteúdo de cada unidade educacional e testes de múltipla escolha com casos clínicos, realizados ao final das unidades verticais

- OSCE e mini-OSCE para avaliação de desempenhos na unidade de Habilidades Profissionais (PROJETO, 2001).

Foram mudados também os critérios de progressão. Atualmente eles prevêem que a avaliação seja feita através da atribuição dos conceitos: Satisfatório e Insatisfatório. O conceito satisfatório é julgado através da comparação do desempenho do estudante com um critério (padrão) estabelecido.

Essa forma de avaliação, a avaliação referenciada segundo critérios, possibilita que cada estudante perceba em que situações ele teria apresentado um desempenho adequado e em quais necessitaria promover melhorias. Pretende-se com este tipo de avaliação eliminar a competição entre os estudantes, que é desencadeada pela comparação e pela classificação segundo notas. Também se pretende promover como referência o padrão de desempenho estabelecido pela escola, a ser utilizado para aspectos formativos no desenvolvimento do processo de ensino-aprendizagem (PROJETO, 1999).

A progressão ocorre através da obtenção do Conceito Satisfatório em todas as unidades de cada série anterior. Os alunos que obtêm conceito insatisfatório são submetidos a um Plano de Recuperação e a uma nova avaliação. Todo conceito insatisfatório é analisado pelo responsável da unidade e discutido com o estudante, e quando necessário com o orientador, para acertos em relação ao plano de recuperação. Identificadas as dificuldades, o plano com a prescrição individualizada para o estudante é acordado entre o estudante, o docente supervisor do plano e o responsável pela unidade. Em geral o percentual de recuperação gira em torno de 90 a 95\% (PROJETO, 1998). 
Existe um grande esforço para avançar na avaliação dos estudantes. A maioria dos entrevistados considera que houve progressos importantes, mas acham que ainda há problemas. Por exemplo, a fragmentação da avaliação das várias esferas (cognitiva, psicomotora e afetiva). "Às vezes conseguimos integrar um ou outro aspecto, mas no geral há fragmentação. Se vamos trabalhar no sentido da melhoria dos desempenhos, essa articulação seria fundamental" (Entrevistado M5).

Um outro problema é o trabalho que a avaliação implica para os docentes: "corrigir 80 provas escritas, com três possibilidades de recuperação para cada estudante - com prescrição individualizada - consome um tempo grande". Também em relação à qualidade das questões e dos casos há dificuldades: "está se buscando atingir taxonomias mais altas e maior articulação das dimensões, mas não tem sido fácil de fazer. Procuramos usar casos diferentes, mas nem sempre isso é possivel" (Entrevistado M5).

"Conseguimos desenvolver um sistema de avaliação razoavelmente compreensivo, sistemático, mas que em alguns aspectos beira o limite da factibilidade. É um processo complicado, trabalhoso, mas muito rico e inovador, que permite um bom feed-back para os estudantes" (Entrevistado M2).

"Na Interação Comunitária foram necessárias muitas mudanças. No comę̧o fazíamos um exercício de avaliação cognitiva e avaliação de performance como qualquer outra unidade. Mas esse esquema era muito rígido, considerando a variabilidade dos trabalhos que era possivel desenvolver. Fomos mudando o formato 3, adaptando às características da Interação; há também uma avaliação do trabalho do grupo e uma metodologia para avaliar o trabalho individual que eles produzem na $3^{a}$ e na $4^{a}$ séries. Um trabalhão, mas tem melhorado" (Entrevistado M4).

\subsubsection{Avaliação do programa}

Inicialmente percebeu-se que os formatos propostos (basicamente quantitativos) não ajudavam muito na avaliação das sessões de tutoria e das unidades. $\mathrm{O}$ preenchimento dos dados era mecânico e pouco discriminatório. As 
observações anotadas nos campos em aberto se revelaram muito mais significativas.

Foram adotados então formatos de campos abertos para registro das observações e uma metodologia de análise de conteúdos para analisar esses formatos.

O resultado era muito interessante, trouxe informações valiosas que foram levadas em conta na capacitação docente e na reconstrução das unidades. Mas a metodologia era muito trabalhosa e implicava um processo muito vagaroso de análise. Conforme foi se ampliando o número de unidades e de anos a avaliar, a equipe de avaliação passou a não ser capaz de dar retorno a respeito dos resultados dentro do tempo desejável.

Atualmente a avaliação docente e das unidades é realizada pelos estudantes ao final de cada unidade. Para essas avaliações a identificação dos estudantes é voluntária e existem formatos específicos, que permitem análises quantitativas e qualitativas.

A avaliação quantitativa tem sempre sido feita e processada. Antes o resultado era devolvido aos docentes e aos estudantes através de um relatório e às vezes através de apresentações ao início da unidade seguinte. Mas isso não tem mais sido possível - por falta de tempo. O retorno tem sido feito prioritariamente para os docentes envolvidos na construção da unidade.

Os resultados da avaliação quantitativa são interessantes, mas limitados "porque ela algumas vezes reproduz exatamente os valores que se pretende mudar. Por exemplo, algumas unidades são avaliadas como muito satisfatórias porque são as mais biológicas e algumas, que tem porcentagem de até $30 \%$ de insatisfatório, são as que procuraram introduzir de modo mais significativo o social e o psicológico. Mas essa distinção, a compreensão do significado da qualificação, só aparece na avaliação qualitativa" (Entrevistado M5). 
A avaliação qualitativa é feita por amostragem intencional. $O$ desenho amostral contempla os depoimentos de todos os docentes que atuaram na unidade e os depoimentos de $50 \%$ dos estudantes de cada grupo (metade que considerou os itens satisfatórios e metade que considerou os itens insatisfatórios). A metodologia para análise é baseada na Análise de Conteúdo, modalidade Temática. Os resultados da avaliação qualitativa têm servido como tema para debate em alguns módulos de capacitação docente e também no Fórum de Desenvolvimento Curricular, que pretende ser anual (PROJETO, 2001).

Neste campo de trabalho, a avaliação do programa, um dos problemas também tem sido o tempo e a sobrecarga de trabalho. São onze pessoas encarregadas de processar e analisar as informações dos dois cursos - medicina e enfermagem e não tem sido possível trabalhar os resultados da avaliação formativa como seria desejável (Entrevistado M5).

No entanto esse esforço é que tem tornado possível a análise e o debate mais profundos acerca de aspectos fundamentais do novo currículo: desvenda problemas ocultos, revela insuficiências, provoca tensões.

$\mathrm{Na}$ prática, por exemplo, a necessidade, identificada pela maior parte dos docentes, de aprofundar seus conhecimentos e compreensão no campo dos fundamentos pedagógicos é fruto desse trabalho incessante de não ficar satisfeito com o já conquistado, de identificar a reprodução das velhas idéias e dos velhos conceitos disfarçados dentro das novas propostas.

Todos os entrevistados concordam que, apesar de muitas vezes ser polêmica, a avaliação tem sido muito útil para repensar e reconstruir todas as atividades envolvidas na implantação da nova proposta.

\subsubsection{A gestão do processo de mudança}

Os cargos formais de direção acadêmica da FAMEMA, depois da estadualização, passaram a ser: a Direção Geral, a Diretoria de Graduação, as 
Coordenações de Curso; e as instâncias de deliberação: a Congregação e os Colegiados de Curso. A Congregação não existia antes e foi rapidamente constituída. Os colegiados levaram mais tempo para serem criados e mais ainda para começar a funcionar.

\section{Os espaços de participação e decisão}

O processo de mudança da FAMEMA, de 1994 até 2000, esteve sob a coordenação do Diretor Geral, que nucleou a constituição de um grupo, que se reunia semanalmente e que foi sendo ampliado ao longo do tempo. Nesse grupo é que se discutiam e definiam as estratégias, que depois eram implementadas ou levadas à aprovação na Congregação ou em outras instâncias pertinentes.

O Grupo de Apoio ao Componente Acadêmico - criado para o desenvolvimento do projeto UNI - foi o embrião desse grupo. Inicialmente o núcleo era constituído pelos coordenadores dos subprojetos acadêmicos, sempre com a participação de representantes dos serviços e da comunidade. Quando o processo de reflexão e construção da mudança acadêmica começou a se intensificar e ganhar direcionalidade, o grupo organizou-se para estudar - dividiram-se por áreas temáticas - e para delinear os vários aspectos de uma proposta políticopedagógica para a instituição (construção de currículo, capacitação, avaliação, tutoria etc). Além de contar com a participação de seus componentes "oficiais", o grupo foi incorporando várias outras pessoas - no geral figuras interessadas na discussão acadêmica ou que podiam cumprir um papel importante no processo de mudança (PROJETO, 1996).

Em 1996, participavam desse Núcleo de Apoio o diretor de graduação, que cumpria a função de coordenador, 4 docentes da medicina, 2 docentes da enfermagem, 2 estudantes, a chefe da Biblioteca, o coordenador do componente serviços do projeto UNI e um representante do Conselho Municipal de Saúde (na figura de um representante dos usuários) (PROJETO,1998). 
Os critérios de definição para participação formal no grupo eram os cargos e funções que as pessoas desempenhavam no processo: um coordenador do grupo de trabalho de revisão curricular da medicina, outro da enfermagem, as coordenações da Interação Comunitária, da Avaliação, da Biblioteca, do Laboratório de Informática, do Laboratório Morfofuncional; cada um dos estudantes representava respectivamente os alunos de medicina e de enfermagem (PROJETO, 1998).

A partir de julho de 1997, a equipe operacional de planejamento e implementação do projeto FAMEMA 2000 passou a ocupar o espaço do Núcleo de Apoio ao Componente Acadêmico. Essa mudança ocorreu de modo informal e teve como objetivo, segundo seu coordenador, aumentar a eficiência na tomada de decisões e na operacionalização das ações (PROJETO, 1998).

Esse grupo era composto pelo diretor de graduação, pelos coordenadores dos cursos de medicina e de enfermagem, pelo coordenador do grupo de Avaliação e pela coordenadora da Interação Comunitária. Perderam espaço de participação, portanto, os representantes dos serviços, da comunidade e, importante destacar, dos estudantes (PROJETO, 1998).

A interface entre academia e serviços passou a se dar nos dois níveis extremos - na cúpula (relações e acordos diretamente entre o secretário municipal de saúde e o diretor geral da FAMEMA) e na base (no espaço dos territórios e dos serviços, envolvendo docentes, estudantes, profissionais dos serviços e também a comunidade). Essa mudança marcou o início do período descrito anteriormente como de "introspecção" da academia e dos serviços, em que cada qual voltou-se para seu processo interno de transformação.

Em 1998 esse núcleo coordenador propôs a criação dos colegiados de curso, que para o curso de medicina teria a seguinte composição: coordenadores de série (6), representantes de estudantes por série (6), coordenador da Avaliação, coordenador da Interação Comunitária e Diretor de Graduação (PROJETO, 1998). 
Apesar da existência dos colegiados de curso ter sido aprovada nessa época, essas instâncias só foram de fato constituídas em 2001 (PROJETO, 2001).

Na prática, portanto, durante um longo período, o que prevaleceu como espaço de direção do processo de mudança foi uma instância informal de aglutinação e também mecanismos informais de comunicação. Havia pelo menos dois momentos semanais de reunião: um momento mais político, chamado estratégico, e outro mais técnico, chamado acadêmico.

No momento estratégico discutiam-se todos os assuntos importantes para a vida da instituição: as relações políticas com o governo estadual, com a secretaria municipal de saúde, a inserção da FAMEMA no movimento nacional de mudanças na formação dos profissionais de saúde e também as estratégias políticas para a gestão da mudança dentro da FAMEMA. No momento acadêmico discutiam-se os aspectos mais técnicos da orientação acadêmica do processo de mudança (entrevistados M1, M3, M4, M5).

O critério para a participação num e noutro momento estava fundamentalmente baseado no grau de proximidade e compromisso político com a direção geral da faculdade. Havia pessoas que eram convidadas a participar da discussão estratégica, mas não tinham "paciência" para isso. E havia outras pessoas que somente eram convidadas a participar do momento acadêmico (entrevistados M1, M3, M4 e M5).

O grupo do momento estratégico era o "grupo que estava no poder", que havia conquistado muita legitimidade dentro da faculdade: inicialmente com o projeto UNI ("conseguir trazer o projeto para esta instituição, que estava desmoralizada e em crise, foi um feito importante"), e depois, mais significativamente, com o processo de estadualização e com orientação da FAMEMA em direção às transformações. Era o grupo que começou a ser construído no final de 1994, com as pessoas que já estavam na FAMEMA e depois com novas pessoas agregadas - geralmente exalunos com grande compromisso com a instituição. Era esse grupo que estava 
conduzindo a FAMEMA em direção a uma situação de viabilidade política, técnica e financeira (entrevistados M1, M2, M3, M4 e M5).

\section{O estilo de gestão}

Manteve-se, tanto para o grupo como para o conjunto de docentes, a política de conquista de adesão e de participação ativa, que funcionava desde o segundo ano do projeto UNI: oportunidades de estudar (capacitações, grupo de estudos, especialização ou pós-graduação em educação médica), de conhecer outras experiências, de construir propostas e de colocá-las em prática.

"Uma estratégia de tirar o individuo do seu lugar e colocá-lo numa realidade diferente. Isso promove um grau de conflito (entre o que você tem e o novo), que é único e quando isso acontece, a pessoa se transforma" (entrevistado M5).

"Era importante saber identificar pessoas com potencial ou pessoas estratégicas e oferecer oportunidades a elas. Era importante perceber inclusive a singularidade de cada pessoa - quer dizer o cara é bom para uma coisa, então vamos aproveitar esse potencial, mesmo que no total ele não seja exatamente como a gente gostaria. No geral, a maioria exposta entrou, mudou e se envolveu. Eu acho que esse foi um dos recursos mais poderosos para a nossa ação estratégica" (entrevistado M1).

O Diretor Geral da instituição cumpria um papel fundamental nesse processo de transformação. Tinha grande respeito e liderança junto ao grupo e junto à maioria dos docentes - apesar de francamente hostilizado pela oposição. Com um estilo muito próprio, estratégico, arrojado, realizador, criador de vínculos, ele tinha uma visão muito precisa do processo em seu conjunto. Participava dos dois grupos - mas principalmente do estratégico - ativava as pessoas, apoiava, mediava conflitos e, quando necessário, chamava para si a responsabilidade direta de resolver as situações mais complicadas e os grandes desafios (entrevistados M2, M3, M4 e M5). 
Essa configuração particular dos espaços de poder e do estilo de gestão permitiu, ao mesmo tempo, um crescimento muito importante da consistência técnica de um contingente expressivo de docentes e a articulação das decisões administrativas com as necessidades técnicas do processo de mudança (entrevistados M1, M2, M4 e M5).

A extinção dos departamentos, a total reestruturação da biblioteca, a criação dos laboratórios de ensino e de informática, o reconhecimento das novas funções docentes, a criação do mapa de trabalho docente ${ }^{8}$, a transformação radical dos critérios de avaliação e progressão dos estudantes são alguns exemplos de medidas administrativas que foram fundamentais para alimentar positivamente ou até para criar viabilidade para a implantação da nova proposta (entrevistados M1, M2, M4 e M5).

Algumas dessas decisões foram arrojadas e geraram muitos conflitos, mas isso era parte do estilo adotado pela direção: analisar o contexto, trabalhar para construir governabilidade e partir para a ação, mesmo que isso implicasse confrontos intensos. "Não só valia a pena, era fundamental enfrentar os riscos para fazer o processo avançar" (entrevistado M4).

Uma outra marca importante da direção foi a valorização da avaliação como instrumento fundamental para a gestão. Desde o início do projeto UNI e depois como instância institucionalizada dentro da FAMEMA (e também nos serviços de saúde), a equipe de avaliação foi estimulada a acompanhar todos os processos, problematizar situações e criar espaços coletivos de discussão.

\footnotetext{
${ }^{8} \mathrm{O}$ mapa do trabalho docente é uma planilha eletrônica criada para gerenciar as atividades dos professores. Todos os docentes passaram a ter que dedicar $50 \%$ do seu tempo a atividades de docência da graduação. Houve um grande estímulo para a qualificação docente, mas as licenças e a liberação para períodos de estudo eram autorizadas de acordo com o mapa e com a certeza de que todos os postos e funções decorrentes do novo currículo estavam cobertos.
} 


\section{A dinâmica do processo}

Numa instituição pequena como a FAMEMA foi possível trabalhar com base em instâncias informais de poder e de organização. Dada a profunda legitimidade que a liderança do processo tinha, inicialmente junto a docentes e estudantes e depois junto aos docentes, o que importava de fato eram os resultados e não os mecanismos formais que haviam sido utilizados para chegar até lá.

No entanto, foi exatamente esse estilo de trabalhar que deu espaço para as acusaçõ̀es de "excessiva centralização" e de "direção ditatorial" que a oposição lançou em vários momentos do processo - especialmente durante as crises e os processos eleitorais (entrevistados M4 e M5).

Outro ponto importante a destacar é que toda a estratégia utilizada estava direcionada a criar massa crítica e apoio ao processo fundamentalmente junto aos docentes. Mas não houve a mesma precisão em relação aos estudantes.

Na eleição de 1993 e durante o processo de estadualização, os estudantes haviam sido grandes aliados e apoiadores entusiasmados da direção da FAMEMA. Não somente apoiavam como participavam ativamente das instâncias onde se construíam as estratégias e se tomavam as decisões.

O momento que antecedeu a decisão pela mudança radical marca uma guinada nessa relação. A estratégia de implantar experimentalmente a metodologia da aprendizagem baseada em problemas em algumas disciplinas teve péssimos resultados, gerando resistências e muitas inseguranças entre os estudantes. E, ao mesmo tempo, fornecendo munição para o grupo da oposição (que acusava a direção de estar sendo precipitada, de querer implantar uma mudança para a qual os docentes não estariam adequadamente preparados).

$\mathrm{Na}$ opinião de vários participantes do grupo gestor, se não há uma mudança do cenário institucional que possibilite oferecer infraestrutura adequada e tempo suficiente aos estudantes para estudar, é muito difícil poder "emplacar" a metodologia de aprendizagem em problemas em disciplinas isoladas que 
convivem com disciplinas tradicionais numa grade curricular inflacionada de disciplinas e sem áreas verdes (entrevistados M1, M2 e M4).

Um profissional da rede, que era estudante na época da implantação das mudanças, conta que

"Minha vida inteira, depois que entrei na faculdade, participei do diretório. Eu estava no terceiro ou quarto ano quando começaram a discutir a mudança do currículo. Houve alguns entraves, é claro, porque eles queriam mudar um sistema que a gente já conhecia, em que um monte de gente antes já havia se formado. E mudar de repente, no meio da faculdade, para um sistema de que a gente nem tinha idéia era muito complicado. Cada aluno pintava um tipo de cabeça de dragão, então você imagina quantas cabeças esse dragão: não eram só sete, eram milhares...

Uma parte do problema por parte dos alunos era em relação ao elitismo: pó, meu pai é cardiologista, meu tio é imunologista...e eu vou ser médico de posto?

Quando eu fui para o quinto ano essa discussão a respeito da mudança da relação médico-paciente, de ela ser mais próxima, mais comprometida, já estava mais clara.

Mas mesmo assim nós achávamos que uma mudança do curso nesse sentido tinha que ser iniciada no começo do ensinamento médico. E não pegar a gente no meio, porque isso não ia dar certo, porque a gente ia estar dividido entre duas orientações.

$O$ diretor do curso de medicina na época tentou negociar com a gente uma proposta intermediária de mudança. Nós apresentamos uma proposta e ele disse - "isso ai está muito quadrado, tem que ser mais próximo da comunidade", mas nós não mudamos de idéia". (grupo focal de profissionais dos serviços e representantes da comunidade $\mathrm{M}$ ).

Depois, durante os primeiros anos da implantação da nova proposta, toda a atenção esteve dirigida "aos novos" estudantes. E as turmas anteriores, que não haviam aceitado muitas mudanças, se sentiram abandonadas e sem possibilidades de usufruir do progresso da faculdade. Restava-lhes somente aproveitar, de algum 
modo, as melhorias de infraestrutura (biblioteca, laboratórios etc.) (entrevistado M1).

No início do novo currículo, como já comentado, havia um trabalho sistemático com os "novos" estudantes. No início, havia conversas quase semanais; depois reuniões ao final das unidades, com a devolução e a discussão sobre os resultados da avaliação. Esse espaço de avaliação possibilitava a manifestação tanto das reivindicações como das ansiedades dos estudantes. Com o passar do tempo, entretanto, por conta da sobrecarga de trabalho e do ativismo, também essas reuniões de devolução sistemática da avaliação deixaram de existir.

Como já comentado, a instalação dos Colegiados de Curso prevista, desde 99, ocorreu somente em 2001. Portanto, durante um bom período deixou de haver espaço formal de participação dos estudantes nas instâncias de decisão. Eles somente eram consultados e se manifestavam durante processo de avaliação das unidades. Informalmente, no entanto, sempre se preservaram as negociações entre a direção e os estudantes, que se manifestavam sempre que julgavam necessário (entrevistados M1 e M5).

Como conseqüência, os estudantes ficaram à mercê de suas ansiedades e de suas experiências. Atualmente estão divididos: os mais antigos, das primeiras turmas da mudança, muito críticos em relação à direção e com muitas dúvidas em relação à qualidade do processo; os mais novos, mais benevolentes em relação à direção e muito entusiasmados em relação à nova proposta:

"Eu diria que houve uma atitude muito de amador mesmo. Antes de implantar o método, não se pensou no que estava errado, no que podia desenvolver. Foi simplesmente ditador, implantaram o PBL 100\% e foram ver no que ia dar" (grupo focal de estudantes $M$ ).

"Acho que nessa coisa das regras tem que ser ditador mesmo, porque se ficar dando muita abertura, o método não daria certo porque de repente o pessoal estaria voltando a dar aula. (...) Então acho que tem que ter essa ditadura em relação ás regras, mas também eles não são tão ditadores assim. Eles se mostraram abertos para conversar. Não sei, pelo menos na minha turma, 
todas as vezes que a gente teve problemas a gente falou e as coisas mudaram" (grupo focal de estudantes $\mathrm{M}$ ).

"Realmente eles estão abertos a mudanças, mas é sempre para a turma que vem depois...Então a minha turma se sentiu como ratinho, cobaia de laboratório" (grupo focal de estudantes M).

"Sabe, eu acho que é ao contrário. As mudanças mostram que o nosso curso de medicina é muito bom, porque ele está sempre em processo de melhoramento. E mesmo no tradicional deveria ser sempre assim. O que eu acho que acontece no tradicional é que os alunos já se acostumaram a pensar que o pai deles estudou daquela forma, assim como o professor que está dando aula para eles. Então, mesmo sem saber se está certo ou errado, eles vão estudar assim mesmo" (grupo focal de estudantes $M$ ).

"Tem umas coisas que a turma do quinto ano saiu prejudicada. Tem umas áreas que no começo era super-largadas e só depois foram ficando melhor (...) Depois, como as coisas podem ser tão diferentes de uma grupo para o outro? Uma turma teve uma palestra, a outra não teve. Isso tudo dá uma sensação de insegurança: será que eu não perdi uma coisa que era fundamental? Será que estudei até onde devia estudar" (grupo focal de estudantes $\mathrm{M})$.

"eu acho que tem muita ansiedade em relação a uma faculdade de medicina porque tem muitos mitos envolvidos dentro da medicina e do ser médico. Eu tenho três irmãos médicos e conversando com eles, eles falam para eu não ter ilusão de que vou sair da faculdade sabendo tudo porque a medicina é um campo muito amplo (...) Então o que a faculdade faz na verdade é introduzir você nesse meio e aí, o resto da sua vida, você vai traçando o seu caminho" (grupo focal de estudantes $\mathrm{M}$ )

Apesar de não haver espaços formais para consulta e discussão tampouco para os docentes - já que o Colegiado não estava funcionando - de algum modo o espaço da capacitação cumpriu esse papel. Ali se discutiam dúvidas, angústias, problemas e se produziam propostas coletivas de solução. Além disso, anualmente foram realizados os Fóruns de Desenvolvimento Curricular, que sempre se 
realizaram durante o recesso da semana da pátria. Essa data favorecia a participação dos docentes (porque é uma semana sem aulas), mas excluía os estudantes (que estavam na INTERMED) (entrevistado M5).

O resultado de tudo isso apareceu nos resultados das últimas eleições: o atual grupo gestor foi mantido na direção especificamente em função dos votos dos docentes - pois perdeu entre os estudantes.

\section{O cenário mais recente e os desafios para o futuro}

A crise financeira dos últimos dois anos implicou piora das condições materiais de trabalho especialmente no hospital. Houve como que um mecanismo de defesa e proteção em relação ao funcionamento dos novos currículos: "era preferível perder a mão que deixar de fazer alguma coisa que era importante para os cursos" (entrevistado M2).

Tal foi o círculo de proteção que se armou, que o grupo acadêmico foi pego de surpresa pelo agravamento da crise (que estava sendo discutida há meses dentro do grupo estratégico e da esfera administrativa) (entrevistado M4).

No início de 2001, nas eleições, o grupo conquistou a possibilidade de mais um período à frente da faculdade. Estratégica oportunidade, pois é a chance da consolidação, mas com uma diferença importante em relação aos períodos anteriores: houve a troca do Diretor Geral. O novo diretor está totalmente comprometido com a proposta de mudança e assumiu o compromisso de ajudar a criar as condições políticas externas (tem relações melhores com o governo estadual) para que o grupo pudesse continuar trabalhando (entrevistados M2, M3, M4 e M5).

"Claro que ele vai estabelecer seu estilo de direção, por exemplo, propondo a fusão dos dois grupos (o estratégico e o técnico). Outra diferença importante é que ele não tem o mesmo perfil e o mesmo poder de coesão junto ao grupo mais próximo. Então um dos desafios colocados para o grupo gestor é aprender a trabalhar e a negociar sem a mediação de uma figura que era 
reconhecida por todos. Aprender a trabalhar e a superar as disputas e divergências internas, que agora se explicitam de maneira muito mais clara do que antes" (entrevistado M1).

Uma outra preocupação de alguns dos participantes é se vão conseguir manter a postura crítica e a disposição de mudança permanente:

"A gente conseguiu avançar muito porque sempre foi muito crítico em relação ao que estava fazendo. Eu estou com medo que a gente esteja com pouca crítica $e$ deixe de pensar nos pontos críticos do currículo".(entrevistado M4)

"Há alguns buracos no currículo que já estão anunciados faz tempo e eu não estou vendo muita disposição agora para enfrentá-los. O desafio é manter os docentes sempre inquietos para construir e ir melhorando cada vez mais. Os grupos de estudo também precisam manter esse pique". (entrevistado M4)

"Tenho medo de a gente achar que está muito bom e parar. Porque também a gente já está cansado... esse tem sido um processo muito intenso, muito exigente e como já conseguimos muita coisa, há um risco de acomodação". (entrevistado M5).

Outros dois temas críticos são o da compreensão do grupo em relação à importância estratégica das relações com os serviços e a comunidade e o da compreensão a respeito da influência do contexto externo mais amplo, nacional, sobre o processo interno de mudança.

Inicialmente, apesar de identificarem, quase instintivamente, a saúde da família como uma estratégia mais favorável para o trabalho na comunidade e nos serviços, poucos docentes estavam de fato envolvidos na construção das alternativas de capacitação e educação permanente nessa área (que dizer, participando ativamente da construção e da implementação dos cursos introdutórios e de especialização) (entrevistado M1). 
Nos primeiros meses de 2002, entretanto, vários docentes se envolveram diretamente nesse trabalho e estão construindo uma proposta de curso de especialização baseada em problemas e na reflexão sobre a prática dos profissionais da saúde da família no campo (entrevistado M1).

Alguns docentes vinham tendo uma participação ativa em outros âmbitos, como a Rede UNIDA, a ABEM, a CINAEM e conquistaram legitimidade própria nesses espaços, especialmente nos dois últimos. Na Rede UNIDA, a participação coletiva de Marília foi sempre mais pontual e menos orgânica, quer dizer, somente há pouco tempo um grupo mais amplo percebeu a importância desse espaço de articulação para conquistar viabilidade externa para o próprio processo interno. Resta ver se o grupo, em sua nova conformação, vai ser capaz de dar o espaço necessário para esses temas, possibilitando uma atuação mais orgânica de seus representantes. 


\section{O trabalho dos projetos UNI na REDE UNIDA}

Ao longo do tempo, durante a implementação dos projetos UNI e, mais adiante, durante a construção dos processos de mudança ao interior de cada um deles, foi possível desenvolver uma compreensão mais profunda a respeito da natureza dessas transformações. Isso foi tornando mais claros o significado da parceria e a necessidade das alianças estratégicas dentro e fora das escolas.

Dentro das escolas a possibilidade de efetivamente mudar e de institucionalizar as mudanças havia dependido essencialmente da capacidade dos projetos de construir processos participativos e de acumular os recursos de poder necessários a vencer as resistências históricas, já de muito estabelecidas. Se existia massa crítica, participante da construção das alternativas, aumentavam as possibilidades não só de mudar, mas de persistir na mudança ao longo do tempo (FEUERWERKER \& SENA, 1999).

A parceria com os serviços de saúde e com as organizações comunitárias foi ao mesmo tempo uma estratégia de mobilização (trabalhar em novos cenários, levando em conta outros atores e seus interesses como estímulo à inovação) e uma estratégia para acumular poder (uniam-se as forças mudancistas existentes em cada segmento para vencer as resistências e os momentos de dificuldade que afetassem quaisquer dos parceiros) (ALMEIDA, 1999).

Foi ficando claro que para construir cenários favoráveis à mudança, tanto para que ela pudesse ocorrer em muitas outras escolas, como para garantir sua sustentabilidade, era necessário atuar no âmbito das políticas públicas, mover forças mais poderosas.

Para isso os UNI consideraram que uma articulação somente entre eles - os 6 projetos UNI brasileiros - seria absolutamente insuficiente. A Rede IDA, apesar de um tanto enfraquecida, pareceu a eles um parceiro ideal, pois nela estavam articulados muitos aliados, participantes ativos do movimento de mudança na formação dos profissionais de saúde no país. Foi, então proposta uma associação 
dos UNI com a Rede IDA (RANGEL \& VILLASBOAS, 1996).

Não bastou, entretanto, uma adesão formal: foi necessário um processo de reconstrução da identidade da rede, que possibilitasse a redefinição e a atualização da temática central em torno da qual se articulavam os projetos, pessoas e instituições.

\subsection{A REDE IDA}

Desde 1985, havia se constituído uma Rede, a Rede IDA, que articulava os projetos de integração docente-assistencial que existiam no Brasil e tinha como característica principal promover o intercâmbio de experiências entre seus membros.

Os projetos de integração docente-assistencial haviam cumprido um papel importante na aproximação de segmentos da universidade (especialmente dos departamentos de medicina preventiva, saúde pública e pediatria) aos serviços de saúde. A rede de serviços, naquela altura, ainda era limitada e as novas propostas de organização de serviços começavam a se esboçar com base nos princípios que depois vieram a reger o SUS (MARSIGLIA, 1995).

Personagens fundamentais da reforma sanitária brasileira estiveram participando desses processos de integração docente-assistencial e dessa articulação em rede, que, naquele momento, cumpriu o papel de romper o isolamento daqueles que eram ainda projetos esparsos no cenário nacional, no contexto da ditadura militar.

Existiram projetos de integração universidade-serviços em praticamente todas as universidades públicas brasileiras e também em algumas privadas. Do ponto de vista do fortalecimento do pensamento e das propostas para o sistema de saúde esses projetos tiveram impacto, pois serviram de ensaio geral para um 
grande contingente de profissionais das universidades que terminou se deslocando para o cenário de construção real do SUS (MARSIGLIA, 1995).

Entretanto seu impacto sobre o processo de formação foi muito limitado. As experiências inovadoras, em muitos casos, permaneceram isoladas nos departamentos de origem, as relações com os serviços em muitos casos eram bastante verticais - quer dizer, a universidade saía a fazer coisas que achava importantes sem levar muito em conta os interesses e necessidades dos serviços e da população, os serviços eram considerados mais como cenários que como parceiros, reproduziam-se objetos e práticas dos cenários tradicionais (FEUERWERKER, 1998). Por conta de tudo isso, foi ocorrendo um desgaste de muitos dos projetos IDA e também da Rede em que eles se articulavam.

\subsection{A construção da nova identidade}

A entrada dos projetos UNI na Rede IDA implicou um longo processo de negociação. Os UNI chegavam com idéias, práticas e ferramentas diferentes das que a Rede historicamente sustentava. Eram projetos ativos, ainda com recursos, alimentados pelos movimentos internos de debate e descoberta de novos caminhos. Traziam de maneira muito mais explícita a questão da parceria em relação aos serviços (parceiro habitual dentro dos projetos da Rede), mas também em relação às organizações comunitárias. E, sobretudo, vinham propor à Rede a idéia de passar a ser um ator político, que interviesse ativamente no cenário da saúde.

Em primeiro lugar, foi feita uma proposta de revigorar, fortalecer a Rede, pois, considerando o contexto brasileiro de construção do SUS e de movimentos difusos em direção à mudança da formação profissional, certamente existia a possibilidade de que dela participassem novos aliados. A Rede, desde então, deixou de congregar apenas projetos e passou a aglutinar também pessoas e 
instituições de formação e capacitação interessadas em desenvolver práticas inovadoras (RANGEL \& VILASBOAS, 1996).

Em segundo lugar foi importante conhecer profundamente a Rede, seus projetos, suas características e, para tanto, foram feitos estudos com o objetivo de identificar a abrangência e natureza dos trabalhos desenvolvidos pelos componentes da Rede. Isso foi fundamental para o processo de construção da nova identidade: características comuns, princípios, limites e potencialidades.

Conhecendo a experiência acumulada, partiu-se, então, para a construção de uma compreensão conjunta acerca de quais eram os principais problemas e oportunidades do contexto e de como se devia, respectivamente, enfrentá-los e aproveitá-las (COSTA et al,2000).

Em 1996, numa oficina de trabalho que reuniu 150 pessoas, foi definida uma nova identidade para a Rede, que passou a se chamar UNIIDA, e construída uma agenda de trabalho que envolvia aspectos internos (relativos ao fortalecimento e funcionamento da Rede) e também a identificação de temas e oportunidades de intervenção da Rede (fortalecer a parceria entre universidades, instituições de pesquisa, serviços e comunidade; atuação política no sentido de "formular política de financiamento para formação e capacitação de recursos humanos para o SUS"; articular ação dos atores da saúde e da educação interessados em mudar o processo de formação; participar da X Conferência Nacional de Saúde defendendo a importância do tema da formação de recursos humanos etc) (RANGEL \& VILASBOAS, 1996).

Foram dados, então vários passos tornar possível de fato funcionar como uma rede, com nós que se associavam e cooperavam. Em primeiro lugar, foi construída uma agenda comum, utilizando o instrumental estratégico situacional; depois foram criados canais de comunicação entre os participantes da rede através da reativação do Boletim impresso, do estabelecimento de uma dinâmica de comunicação eletrônica e da criação do website da Rede (COSTA et al, 2000).

Uma outra estratégia foi a de criar espaços de debate, reunindo atores que 
não costumavam se encontrar, para aprofundar a discussão e construir uma compreensão mais profunda acerca dos principais desafios colocados para a construção do SUS e para a formação de profissionais de saúde.

Ao final dessa etapa do processo, em 1998, a Rede, agora já chamada UNIDA, era concebida como: "Espaço de troca e divulgação de experiências de articulação entre universidades, instituições de ensino e pesquisa, serviços, comunidade, constituída por projetos, instituições e pessoas interessadas em promover mudanças no modelo de atenção, no modelo de ensino em saúde e nas formas de participação social, coerentes com os princípios do SUS", assumindo como sua temática central a "Formação e Capacitação de Recursos Humanos em saúde" (COSTA et al, 2000) (ROVERE,1998).

\subsection{A construção da rede como ator social buscando influir nas políticas públicas}

Paralelamente, se fez um trabalho para que a Rede fosse reconhecida como um ator preocupado com o tema da formação dos profissionais de saúde e que tinha algo a dizer na solução dos problemas dessa área. Para isso foi feita relativamente ampla divulgação das experiências, participou-se em todos os eventos significativos da área da saúde e da formação profissional, foram criados espaços de interlocução com os atores estratégicos na definição das políticas públicas e feita ampliação da rede de contatos informais que poderiam abrir novos canais de negociação (COSTA et al, 2000).

Ao longo desse trabalho de aproximação e articulação, foi possível constatar que não havia tematização adequada, em relação à formação dos profissionais de saúde, nos espaços de discussão e de decisão das políticas de saúde e de construção do SUS. Uma das hipóteses para explicar esse vazio era o predomínio da concepção de que as mudanças na organização do sistema de saúde antecederiam e determinariam as mudanças na formação profissional, 
considerando o poder de pressão e conformação do mercado - idéia defendida por gestores do Sistema de Saúde e por atores das próprias instituições formadoras (ALMEIDA, 1999).

A Rede discordava dessa tese. Acreditava que os dois processos teriam que ser construídos simultaneamente e de maneira articulada. Considerava que estudantes, docentes e comunidades poderiam contribuir para a mudança do modelo de atenção, um dos desafios do SUS ainda por enfrentar. Considerava também que a mudança da universidade não poderia ser construída somente em seu interior e essa compreensão se fazia mais clara à medida que avançavam as tentativas de construção das mudanças dentro das escolas, especialmente nos projetos UNI.

Por isso a Rede propunha o trabalho articulado entre universidades, serviços de saúde e organizações comunitárias como uma das principais estratégias para produzir mudanças. Considerava que nestes três segmentos existem atores sociais que poderiam cumprir um papel relevante na transformação da formação e do modelo de atenção à saúde. Essa foi a base conceitual que alimentou o esforço da Rede para difundir e analisar criticamente as experiências que envolvem a ação articulada desses segmentos e buscam produzir transformações sinérgicas em todos envolvidos (COSTA et al, 2000).

Para fortalecer essa tese, a Rede passou a articular-se com todos os setores e segmentos que procuravam incluir a questão da formação e da capacitação profissionais na agenda política dos distintos atores estratégicos da saúde e da educação. Foram inúmeras visitas, propostas, reuniões, seminários, envolvendo os Conselhos Nacionais de Saúde e de Educação, CONASS, CONASEMS, entre outros.

Como resultado dessa ação sistemática, a Rede foi chamada a assessorar o Conselho Nacional de Saúde na questão da formação de recursos humanos e nessa condição participou da mesa sobre recursos humanos que o Conselho patrocinou na XI Conferência Nacional de Saúde. Também o CONASEMS tem convidado a 
Rede a falar em seus congressos nacionais: sobre Trabalho em Rede em Goiânia (1999), sobre a importância da mudança da formação de recursos humanos para os gestores do SUS (2001).

A partir da identificação, no contexto, de oportunidades consideradas estratégicas, a Rede também procurou intervir no cenário político, produzindo propostas concretas que pudessem favorecer a mudança na formação (COSTA et al, 2000).

O exemplo mais interessante dessa ação foi o trabalho da Rede em torno da Proposta para as Diretrizes Curriculares para as profissões da saúde. Com a aprovação da nova Lei de Diretrizes e Bases, o Ministério da Educação lançou um edital que instalou no país um processo de debate acerca das novas diretrizes curriculares que vão orientar a formação profissional. A Rede considerou que essa poderia ser uma excelente oportunidade para ampliar o debate sobre a imagemobjetivo do processo de formação e criar um cenário legal que favorecesse e estimulasse os processos de mudança.

A Rede, então, iniciou um processo de mobilização de seus membros para construir, com base nas experiências dos projetos inovadores, uma proposta de diretrizes que se constituísse claramente numa perspectiva para os processos de mudança na formação dos profissionais de saúde. Desencadeou, também, um forte trabalho político de mobilização de todos os atores potencialmente interessados no tema, incentivando sua participação ativa no processo, de modo a que realmente se configurasse uma definição democrática em torno do tema (REDE UNIDA, 1998).

Considerando que o SUS deveria cumprir o papel de ordenar a formação de recursos humanos em saúde e não vinha cumprindo esse papel, a Rede e outros atores significativos, como a Associação Brasileira de Educação Médica - ABEM e a Associação Brasileira de Enfermagem - ABEn pressionaram insistentemente alguns dos importantes atores da saúde (Conselho Nacional de Saúde, Conselho 
de Secretários Estaduais de Saúde, Conselho dos Secretários Municipais de Saúde, Coordenação de Recursos Humanos do Ministério da Saúde etc.) para que se posicionassem no debate, apresentando suas sugestões a respeito do perfil do profissional necessário (COSTA et al, 2000).

Os resultados foram muito interessantes. Apesar de algumas resistências, as escolas, especialmente de Medicina e Enfermagem, tiveram uma participação ativa no debate provocado e fortalecido pela intervenção da Rede. Nesse processo, a Rede foi também um ator ativo na busca da construção do consenso entre as várias entidades e movimentos.

As Comissões de Especialistas, que inicialmente não haviam levado em conta as contribuições dos debates coletivos na construção de suas propostas, foram pressionadas a recuar. Finalmente, as propostas aprovadas pelo Conselho Nacional de Educação corresponderam às expectativas dos movimentos de mudança da formação profissional na área da saúde.

Todo esse trabalho em torno das diretrizes ampliou a visibilidade da Rede, favorecendo seu reconhecimento como interlocutora para as questões de Formação e Capacitação de Profissionais de Saúde, trazendo legitimidade ao movimento, criando possibilidades para continuar a mobilização em favor das mudanças (COSTA et al, 2000).

\subsection{Outras linhas de trabalho em favor de um contexto mais favorável às mudanças}

Além de buscar constituir-se num ator político capaz de influir nas políticas públicas, a Rede implementou também outras estratégias. Uma delas foi a divulgação, por todos os meios, da experiência aprendida nos projetos membros da Rede, demonstrando a necessidade e a possibilidade de mudanças na formação profissional. 
Para tanto, foi fundamental a sistematização das experiências. Sistematização é o processo de reflexão organizada para interpretar coletivamente uma experiência e construir ensinamentos a partir dela. Ou seja, parte-se da experiência e da prática vivas - em ação - para construir uma visão ou sentido compartilhado a seu respeito. É uma modalidade de construção e disseminação democrática do saber.

É uma metodologia que teve origem em experiências de desenvolvimento comunitário e de auto-gestão do conhecimento (Paulo Freire, pesquisa-ação) e que tem postulados epistemológicos, filosóficos e políticos que defendem a produção do saber a partir da prática, a apropriação e o uso do conhecimento pelos participantes de determinada experiência ou situação, a importância da democratização do poder do saber etc. (GAJARDO, M, 2000); (BONILLA et al, 2000); (ANTUNES, 2001).

A reconstrução ordenada das experiências oferece a possibilidade de identificar e compreender mais profundamente quais foram as intervenções estratégicas para chegar às mudanças em cada contexto e em cada momento. As perguntas cumprem papel estratégico nesse processo. Por um lado, elas servem para mobilizar e orientar a reflexão, abrem a porta para o diálogo entre distintos saberes e enfoques frente a uma experiência vivida conjuntamente. Por outro lado, as perguntas servem para ajudar a estabelecer relações entre as estratégias e metodologias, os resultados obtidos e as características dos contextos interno e externo dos projetos. Essa é a chave para poder usar critica e estrategicamente as lições aprendidas em outros contextos e situações.

Por essa razão, a Rede tem investido fortemente na criação de espaços e momentos coletivos de reflexão organizada sobre suas experiências, mecanismo através do qual foram produzidos vários documentos e revistas de divulgação (REDE UNIDA, 2000d).

Foi durante uma das oficinas de sistematização, em que se trabalhava sobre o tema da construção de novos modelos de formação, que os projetos UNI de 
Londrina e de Marília começaram uma reflexão mais explícita a respeito das novas questões que tinham que ser enfrentadas em seus processos de mudança para que pudessem de fato avançar como mudanças profundas (REDE UNIDA, 2000b).

Essas novas questões vão desde a institucionalidade maior, ou seja, a necessidade de transformar regras e normas universitárias e dos serviços de modo a assegurar a viabilidade das propostas inovadoras, até a de enfrentar temas e problemas antes não imaginados.

Entre estes temas se inclui a necessidade de democratizar as relações, abrindo espaço para a intervenção de vários sujeitos (novos) tanto no processo de ensino-aprendizagem, como no de construção da saúde. Também se inclui a necessidade de reconstruir a prática clínica, ampliando-a, incorporando elementos e recursos que tornem possível uma atenção mais integral; a necessidade de transformar o espaço do hospital e da prática ambulatorial, a necessidade de rever as relações e os papéis entre especialistas e generalistas e entre as várias profissões da saúde. E também a necessidade de ter coerência entre concepção e prática em todos os cenários de atuação, o que envolve articulação e sintonia profundas entre universidades e serviços de saúde etc.

A identificação de uma agenda de temas tão complexos somente reforçou a proposta de ação estratégica da Rede no cenário nacional. Tanto para reunir aliados para a construção conceitual que se faz necessária para dar conta de alguns desses dilemas, como para contribuir para a construção de relações de força e de oportunidades de contexto que favoreçam as mudanças (REDE UNIDA, 2000d).

Daí a proposta de uma oficina para construir uma nova agenda estratégica para a Rede UNIDA, que aconteceu em setembro de 2000 na Bahia e que propôs, sinteticamente três linhas para o trabalho da Rede:

- Ampliação das articulações entre os que trabalham a mudança na área educacional para fortalecer as intervenções no âmbito das políticas públicas, 
considerando que há muitas iniciativas que caminham no mesmo sentido, mas estão ocorrendo sem coordenação.

- Redefinição e ampliação da articulação e interação entre Universidades e Serviços de Saúde na direção de uma gestão colegiada do processo de integração ensino-serviço. Para isso seria importante criar um espaço de discussão a nível nacional no sentido de estabelecer como diretriz política das secretarias municipais de saúde o compromisso com a formação profissional e com a construção de espaços locais de colaboração com as escolas da área da saúde. A proposta inicial era negociar entre Rede e CONASEMS os primeiros passos para viabilizar a iniciativa

- Considerando que há pouco amadurecimento na discussão da formação profissional como um todo (quer dizer, articulando suas várias partes), promover oportunidades de debate amplo com difusão e uso de informação, estudos. Isso para que se possa chegar a uma revisão do processo de formação envolvendo a graduação e pós-graduação e sua articulação para atender as necessidades e demandas sociais em relação a: adequação da formação; produção de conhecimento; educação permanente dos profissionais (REDE UNIDA, 2000d).

Os atores identificados como parceiros potenciais da Rede para essas ações incluíam, entre outros, os Fóruns de Pró-Reitores de Graduação e de Extensão, a ABRASCO, a CINAEM, a ABEM,a ABEn, o CONASEMS, o CNS, setores do MEC e setores do MS. Com maior ou menor proximidade e afinidades políticas, a Rede de fato tem estabelecido diálogo e ações conjuntas com vários desses atores (REDE UNIDA, 2001b).

O IV Congresso da Rede UNIDA, realizado em Londrina em outubro de 2001, foi mais uma demonstração do interesse e mobilização em torno do tema "mudanças na formação dos profissionais de saúde" e do reconhecimento da Rede UNIDA como portadora de experiências e propiciadora de debates nesse campo. 
A secretaria executiva da Rede UNIDA esteve sob responsabilidade da Universidade Federal da Bahia no período de 1995 a 2000 e atualmente está sob responsabilidade da Universidade Estadual de Londrina. Ultimamente vem sendo desenvolvido um intenso trabalho de mobilização e articulação para possibilitr participação mais orgânica e ativa dos quase mil membros associados à Rede.

Tem sido, portanto, através da REDE UNIDA que os projetos UNI de Londrina e de Marília (juntamente com os demais UNI) vem trabalhando no contexto político brasileiro. 


\section{Discussão}

A escola médica, como outras instituições, em suas atividades e seus programas, é um dos âmbitos sociais em que se concretiza uma dupla disputa de poder - em curto prazo, em torno do poder cotidiano e em médio prazo, do poder societal. E o que é que se disputa? Disputa-se a definição a respeito de quais coisas fazer e de como fazê-las.

Se no cotidiano das instituições e dos setores, o poder é uma categoria analítica com enorme capacidade explicativa (TESTA, 1995), para a análise de processos de mudança é a categoria analítica central. Considerando política como uma proposta de distribuição de poder e estratégia como forma de implementação de uma política (TESTA, 1995), tomei política, estratégia e poder como as três categorias centrais para analisar os processos de mudança nos cursos médicos de Marília e de Londrina.

\subsection{Uma leitura estratégica dos processos de mudança}

Nos dois casos estudados, no entanto, a existência dos projetos UNI faz com que se configure um âmbito de operação que vai além das escolas médicas, em razão do trabalho articulado com as outras carreiras e também com os profissionais dos serviços e com as organizações comunitárias.

Vale a pena examinar rapidamente algumas das principais idéias do programa UNI que interferiram de algum modo na maneira como a questão do poder e da participação dos atores sociais foi trabalhada nesses dois casos.

\subsubsection{O Programa UNI}

Muito embora o programa não seja o objeto de análise deste trabalho, é importante discutir, ainda que brevemente, alguns aspectos da proposta, pois foi 
sobre essa base inicial que os projetos de Marília e de Londrina foram construídos. Além disso, ao longo do tempo, os dois projetos foram participantes do processo de reconstrução conceitual da proposta UNI e, ao mesmo tempo, novamente influenciados por suas proposições.

Já de saída, a partir da concepção do programa UNI, o cenário proposto para a construção dos projetos de mudança não estava restrito às escolas médicas e sequer à universidade: ao menos a articulação entre duas carreiras (medicina e enfermagem) era necessária e, mais ainda, era pré-requisito a articulação com os serviços de saúde e as organizações comunitárias da área em que se pretendia trabalhar (KISIL \& CHAVES, 1994).

Essa proposição havia sido construída a partir da análise da experiência empírica de tentativas anteriores de mudança, que mostrara que projetos de mudança construídos somente ao interior das escolas não haviam tido "capacidade" de produzir os resultados esperados. As iniciativas anteriores de "ampliação" do cenário tampouco haviam sido suficientes, já que a articulação pontual com os serviços de saúde (IDA) e as experiências de atenção primária ou outras estratégias baseadas no conceito da extensão universitária não haviam sido capazes de produzir as mudanças profundas que se desejara.

Não se propunha somente a ampliação do cenário "físico", incluía-se na proposta a participação ativa dos atores dos serviços de saúde e das organizações comunitárias, pois havia a percepção de que trabalhar nos cenários reais e sobre problemas da realidade era importante para a formação de profissionais mais comprometidos com a realidade social (ROSA, 1994).

A participação dos serviços de saúde no UNI não era pensada como instrumental, ou seja, eles deveriam ser um parceiro com um projeto próprio de mudança e não simplesmente os cenários onde as inovações no processo de formação ou na participação popular aconteceriam. As propostas nesse terreno baseavam-se fundamentalmente na idéia de construir e fortalecer os sistemas locais de saúde, ampliar o uso da epidemiologia na gestão local, introduzir o 
planejamento local participativo e estimular a abordagem e o trabalho multiprofissional e intersetorial.

A abordagem conceitual do programa em relação à comunidade inicialmente era contraditória. Por um lado também eram concebidos como parceiros e o projeto como uma oportunidade para o fortalecimento da cidadania (ISQUIERDO, 1994), mas em muitos momentos eram reduzidos à categoria de usuários e, portanto, destituídos de seu papel de sujeitos sociais (CARDARELLI, 1996).

O ideário do UNI também trabalhava com a questão da influência dos aspectos "sistêmicos" sobre o modo de produzir médicos e de organizar os serviços de saúde. Propunha-se, aos projetos, o desafio de "disseminar" seus bons resultados, com o objetivo de provocar mudanças sistêmicas, traduzidas principalmente como mudanças nas políticas de saúde e de educação (KISIL \& CHAVES, 1994).

O referencial teórico que informava a proposta do programa era híbrido, mas baseado fundamentalmente numa abordagem sistêmica (ALMEIDA, 1999).

De várias maneiras, ainda que não discutida explicitamente, a questão do poder estava presente conceitualmente na proposta inicial do programa:

- a porta de entrada e a inserção dos projetos dentro das instituições de saúde e educação e das organizações comunitárias

Propunha-se (e esse foi um dos pré-requisitos para a aprovação das propostas) que os projetos entrassem na universidade a partir de um compromisso institucional, da direção das instituições, com as propostas de mudança.

Essa exigência revela a compreensão de que para desencadear processos significativos de mudança era necessário que os projetos estivessem inseridos dentro dos núcleos centrais de poder das instituições.

- a proposta da parceria materializada na participação dos três segmentos desde a elaboração da proposta e no estabelecimento de instâncias tripartites 
para a direção dos trabalhos em todos os seus aspectos, inclusive na definição da utilização dos recursos financeiros

Esse foi o primeiro passo para o estabelecimento da relação entre os parceiros. Desde o início na maior parte dos projetos houve representação efetiva dos três segmentos nas instâncias de direção política. No entanto isso se revelou insuficiente para a construção de relações efetivas de parceria e foram, então, criadas instâncias intermediárias e outros mecanismos que possibilitaram a interação entre professores, estudantes, profissionais dos serviços e representantes da comunidade na elaboração e na operacionalização das propostas de trabalho.

- o desenvolvimento de estratégias que possibilitassem que o maior número possível de atores tivessem participação ativa nos projetos

Sabia-se que os UNI seriam iniciados pela ação efetiva de um núcleo de pessoas mais mobilizadas da universidade, dos serviços e da comunidade, mas havia a preocupação de ampliar a participação, especialmente incorporando professores dos mais variados departamentos. Ou seja, já existia a compreensão de que nenhuma mudança significativa poderia ocorrer sem a participação efetiva de grande parte do corpo docente.

- a inclusão na matriz de avaliação do programa das seguintes "dimensões" (KISIL \& CHAVES, 1994); (TANCREDI et al, 1999):

- parceria (entendida como espaço compartilhado de planejamento, decisão e operação);

- a adesão ao projeto e participação nas atividades; a comunicação e difusão (entendidas como ferramentas para ampliar o conhecimento e a adesão)

- a institucionalização (entendida como incorporação das inovações introduzidas ao modo de operar das instituições).

Segundo opiniões expressadas em vários momentos de reflexão sobre o programa UNI, a existência dessas dimensões na matriz avaliativa foi fundamental para que elas entrassem na "agenda" dos projetos como questões a serem enfrentadas 
conceitualmente (concordando, discordando, ampliando as formulações originais do programa e da equipe de avaliação) e na prática (através da elaboração de estratégias específicas).

Portanto, apesar de suas limitações conceituais, o desenho do UNI colocou como desafio prático para os projetos o enfrentamento das questões do poder, possibilitando, aos que tiveram essa percepção do tema, a busca de alternativas. Além disso, a proposta da parceria (e seus mecanismos de concretização) abria espaço para que a população fosse tomada como ator social, inicialmente dentro dos projetos e depois em espaços institucionais de intervenção e trabalho conjunto.

A conformação de espaços coletivos de trabalho e de discussão, incluindo participantes dos três segmentos, criava o potencial de constituição de sujeitos sociais, elemento indispensável para a existência de poder transformador (MATUS, 1996); (TESTA, 1995). Muito embora essa compreensão só fosse incorporada aos debates dentro do programa e dos projetos a partir de 1997 (PROGRAMA, 1997b); (PROGRAMA, 1997d); (PROGRAMA, 1998), esse processo - de constituição de sujeitos através da democratização das relações e dos espaços coletivos de discussão e ação - concretizou-se desde logo nos projetos.

Como havia "liberdade de operação", cada equipe local pôde identificar e utilizar outros recursos teóricos e instrumentais, que lhes parecessem mais adequados (ALMEIDA, 1999). Vários projetos adotaram, ao longo do tempo, o referencial do pensamento estratégico (PROGRAMA, 1997d) como base para sua elaboração e operação: Londrina (Rovere em 1996) e Marília (Matus em 1997) estavam entre eles.

Além disso, ao longo do tempo, o ideário com que operava o Programa foi sendo transformado, enriquecido pelas reflexões a aprendizagens propiciadas pela implementação dos projetos (CHAVES et al, 1999). Em conseqüência, o programa de apoio ao desenvolvimento dos projetos passou a funcionar como incentivador e alimentador das ações estratégicas dos projetos. 


\subsubsection{Os projetos UNI como programa de ação estratégica}

Nesses dois processos de mudança, pode-se dizer que os projetos UNI funcionaram como um programa de ação estratégica. O programa UNI influiu de maneira decisiva na base conceitual utilizada na implementação inicial dos projetos, na definição do que seria a composição de seu núcleo central, na configuração de espaços coletivos de discussão (externos aos projetos) e no estímulo à sistematização das experiências.

Cabe ressaltar que a existência de um ideário UNI, de um processo de avaliação e de uma linha de atividades de apoio do programa serviu fundamentalmente para dar maior organicidade e consistência ao trabalho dos projetos. Sua orientação não foi nunca no sentido da ação normativa ou prescritiva, já que se levava claramente em conta a diversidade de contextos e a necessidade de que se encontrassem soluções apropriadas para cada um deles. Portanto, os projetos tiveram liberdade para configurar suas propostas e para adotar outros referenciais teórico-metodológicos.

Internamente às instituições acadêmicas, os projetos foram construídos a partir de iniciativas do núcleo central de poder (nos dois casos a direção do projeto era atribuição do diretor - da faculdade em Marília e do centro de ciências da saúde em Londrina). Ao mesmo tempo, em função da parceria com os serviços de saúde e com as organizações comunitárias, os projetos instituíram um espaço social mais amplo que implicou e possibilitou efetivamente a participação de outros atores sociais, externos à academia.

Os UNI tinham um objetivo definido, que era provocar a mudança. Nos termos em que estava colocada a proposta, além de conferir maior direcionalidade às ações, o projeto significou a oportunidade de pensar o trabalho institucional de maneira mais ampla, porque inserido claramente no contexto local.

Mobilização efetiva, maior direcionalidade, recursos materiais disponíveis para desencadear múltiplas atividades e iniciativas de construção de capacidade 
em várias áreas e a constituição de espaços coletivos (de discussão e de ação): sem dúvida esses foram elementos de "empoderamento" dos núcleos condutores das mudanças. Ou seja, o projeto foi transformado em uma significativa fonte de recursos de poder (técnico, político e financeiro), melhor ou pior utilizada pelos núcleos dirigentes dos dois processos ao longo do tempo.

Sobretudo em Marília, o projeto serviu também para a configuração do próprio núcleo diretivo, que assumiu a condução do processo de mudança e soube construir progressivamente maiores graus de consistência técnica e política e de legitimidade.

Em Londrina desde o início foram necessárias alianças e acordos políticos, que se concretizaram inclusive na composição inicial do núcleo dirigente do projeto. As diferenças políticas, as disputas, as relações conflituosas no passado dificultaram a construção de laços fortes de solidariedade internamente ao grupo, o que restringiu a possibilidade de funcionamento mais orgânico. Mais tarde, quando o projeto deixou de ser usado como uma ferramenta estratégica, seu grupo dirigente perdeu força política e o papel de direção da mudança foi cumprido por outras instâncias.

TESTA (1995) diferencia três tipos de programas estratégicos dentro de um processo de mudança. O primeiro é chamado de programa de abertura e serve fundamentalmente para a acumulação de poder técnico através da mobilização de grupos em torno da problematização de conceitos e de práticas (que são o alvo da mudança) e de poder político através da constituição de sujeitos (que serão os construtores da mudança).

O segundo é chamado de programa de avanço e corresponde à realização efetiva da mudança, que só foi possível em função do poder acumulado na primeira fase. É quando se estabelecem novos papéis, novas relações, novas maneiras de realizar e se definem novos conteúdos para o trabalho e a maior ênfase está no poder político. 
O terceiro é chamado programa de consolidação, que serve para não perder o terreno conquistado. Como nenhum avanço é linear e às vezes apresenta retrocessos importantes, é preciso reforçar o processo com ações que dependem das características políticas do processo de mudança. Pode ser necessário desenvolver estratégias para fortalecer politicamente o grupo que sustenta a mudança ou pode ser necessário somente garantir base material para que as ações se realizem e continue existindo a possibilidade de enfrentar os novos problemas que surgem, garantindo poder para que possa ocorrer a institucionalização da mudança.

Os projetos UNI em Marília e em Londrina cumpriram o papel desses três tipos de programa estratégico. Houve três fases de financiamento, acompanhadas de assessoria técnica e política: duas a título de implementação da proposta UNI e uma a título de fortalecimento das mudanças acadêmicas que se haviam desencadeado nos dois projetos.

A primeira fase e uma parte da segunda fase UNI corresponderam basicamente ao período de acumulação de poder e de construção do projeto de mudança (ou seja, constituiram-se num programa de abertura). Parte da segunda fase UNI e parte da do financiamento específico da reforma corresponderam ao período de implantação das mudanças (ou seja, um programa de avanço). No atual momento, com os recursos financeiros limitados do projeto de apoio às reformas e com o apoio técnico do programa de apoio do UNI, os projetos se encontram na fase de consolidação.

Cada projeto, em função do processo de construção das fases anteriores, necessita agora de um tipo diferente de programa de consolidação (Londrina no primeiro caso - em que é ainda necessário fortalecer o grupo que sustenta as mudanças - e Marília no segundo - em que é necessária base material para garantir o enfrentamento dos novos problemas que surjam).

É importante destacar o papel que cumpriram os recursos nos dois casos analisados. Os recursos financeiros sem dúvida genericamente conferem maior 
poder ao grupo que está à frente de um processo: maior poder porque há possibilidades de concretizar as estratégias necessárias para mobilizar, sensibilizar, construir capacidade técnica e política. No entanto, se. não se desenvolvem as estratégias, os recursos financeiros, por si só, não garantem a governabilidade necessária para implementar as mudanças (como se pode perceber nos últimos anos em Londrina, em alguns outros projetos UNI e em inúmeros outros casos de projetos não exitosos).

Em nenhum dos dois casos o final do financiamento representa risco de descontinuidade ou de retrocesso, já que os processos de mudança foram incorporados e estão ocorrendo no interior "das entranhas" institucionais. Nos dois casos, além do mais, já se conseguiram alternativas para produzir os recursos necessários para continuar existindo a possibilidade de fazer investimentos estratégicos. Atualmente os riscos existentes - os que podem de algum modo ameaçar ou prejudicar os processos de mudança em curso - são de caráter político e não se solucionam com a existência de recursos financeiros.

\subsubsection{A gestão estratégica do processo de mudança no curso de medicina}

Como comentado, houve uma primeira fase de trabalho que serviu basicamente para a acumulação de recursos de poder (técnicos e políticos), caracterizada principalmente por dois tipos de iniciativas. A primeira foi a busca dos conhecimentos necessários para poder definir mais claramente o lugar onde se queria chegar e o caminho para fazê-lo.

Ou seja, apesar de haver existido mobilização e capacidade de elaboração, suficientes para produzir projetos (UNI) e declarar uma intenção institucional de mudança, havia uma compreensão limitada a respeito das alternativas conceituais para substituir o modelo tradicional de formação e, em conseqüência, das estratégias adequadas para tanto (GARANHANI, 1999); (PROJETO, 1994). 
A busca de referenciais ocorreu especialmente nas áreas pedagógica e de gestão da mudança e, foi mais ou menos prolongada, dependendo do nível de acumulação prévia no debate e nas experiências de inovação educacional.

Londrina, uma universidade, com antecedentes de inovação tanto dentro da universidade como dos serviços de saúde e de participação ativa no movimento da reforma sanitária brasileira, já contava com uma massa crítica mais significativa, detentora de referentes conceituais mais claros.

Por isso foi possível, logo de saída, produzir as estratégias de sensibilização e mobilização, inicialmente com o PEEPIN (práticas multiprofissionais desenvolvidas no espaço da comunidade e dos serviços de saúde utilizando a metodologia da problematização) e depois o PAPS (estímulo à investigação interdisciplinar e multiprofissional) e PAPIENS (estímulo à iniciativas de ensino interdisciplinar). Também identificaram precocemente a necessidade de se apropriarem de ferramentas do planejamento estratégico para melhor conduzir o processo.

Em Marília, uma faculdade isolada, marcada por importantes crises financeiras e escassas oportunidades de estudo e investigação, o processo de busca de referenciais foi mais longo, tanto no campo da educação como no das estratégias para construção de mudanças. Foram múltiplas as fontes exploradas e várias as alternativas, experimentadas e descartadas, até ser possível uma definição.

A segunda marca dessa primeira fase dos processos de mudança foi a implementação das atividades de mobilização e sensibilização de docentes, profissionais dos serviços e estudantes. Em Londrina, as já mencionadas; em Marília, basicamente atividades de capacitação e o desenvolvimento de atividades nos serviços de saúde pelos professores das áreas clínicas.

O objetivo principal das atividades de mobilização e sensibilização foi criar oportunidades para que os docentes pudessem refletir criticamente sobre sua prática, esperando assim ampliar a base de sustentação para uma futura mudança. 
Ou seja, foi através desse processo que se constituíram os sujeitos, cuja ação foi fundamental na construção das propostas, no momento da decisão e depois, na implantação da mudança.

A heterogeneidade das identidades profissionais entre os membros do corpo docente das faculdades de medicina tornou essa tarefa mais complexa. Há médicos e não médicos; há profissionais dedicados principalmente à docência, outros principalmente à pesquisa, outros ainda que combinam as duas atividades e também os que estão dedicados principalmente à assistência. Há ainda diferenças importantes na qualidade dos vínculos dos docentes com a universidade, já que há contratados por tempo integral, parcial e horistas.

Todas essas diferenças configuram inserções profissionais distintas (como pesquisador, como docente, como clínico), que implicam diferentes construções ideológicas dos sujeitos e posturas potencialmente distintas diante de propostas de mudança (TESTA, 1995).

$\mathrm{Na}$ construção de uma mudança é necessário considerar essas diferenças e fazer uma análise estratégica, que inclua a avaliação do potencial de adesão e de influência de cada um dos grupos e pessoas-chave, para, então, desenvolver propostas específicas de mobilização ou de neutralização.

Nos dois casos analisados, o processo de mobilização de grupos foi feito principalmente através de iniciativas de avaliação crítica das práticas, oportunidades de capacitação, de conhecimento de outras realidades e de experimentação prática de alternativas possíveis para mudanças metodológicas e de abordagem temática.

Esse movimento de refexão crítica foi fundamental para que de fato se esgotasse, para os docentes, o modelo tradicional de ensinar, trabalhar e participar como alternativa exclusiva de organização de várias esferas da vida. Ao mesmo tempo essa prática problematizadora foi essencial para que já se fossem gestando as estratégias inovadoras de ensino-aprendizagem, de trabalho nos serviços e de participação popular. 
Portanto, para que as pessoas se colocassem em movimento, dispostas a construir práticas alternativas, foi necessário que elas se sentissem "desconfortáveis" em sua situação presente. Atividades com esse potencial de "criar desconforto" e possibilitar às pessoas a percepção de "poder agir" são chamadas, na linguagem do planejamento estratégico situacional, de "acontecimentos sociais".

São essas atividades que têm o potencial de provocar impactos sobre a consciência social, que é a forma de conhecimento coletivo que constitui a base da compreensão de um problema (TESTA, 1995). Ou seja, são oportunidades que suscitam a "desnaturalização" da percepção da lógica da organização tradicional da docência, da investigação etc. e mostram a possibilidade de ação em outro sentido. Também através delas é que os sujeitos se convertem em sujeitos coletivos ou atores sociais e tomam parte ativa na construção da mudança.

Um outro tipo importante de ação estratégica é propiciar a acumulação de poder técnico em áreas específicas que serão fundamentais para a construção e implantação da mudança. Para tanto é necessário identificar as próprias limitações e fragilidades, ter uma visão clara a respeito do projeto futuro e dispor dos recursos adequadamente. Claramente esse foi o caso em Marília nas áreas de biblioteca, informática e avaliação e, nos dois casos, na esfera do projeto políticopedagógico .

Nos dois casos analisados, portanto, o processo de mobilização e de constituição de sujeitos durante a primeira fase, possibilitou reunir poder suficiente para neutralizar as forças opositoras e para levar a proposta de mudança à frente.

\subsubsection{A implantação da mudança}

A acumulação de poderes é condicionada por muitos elementos como a complexidade institucional, suas tradições e seu prestígio, o grau de insatisfação existente em relação ao modelo tradicional, crises, perspectivas de futuro da 
instituição, tipo de vinculação e compromisso dos profissionais com a instituição etc. Características essas que fazem parte do diagnóstico estratégico e que têm que ser levadas em conta na elaboração das estratégias - por isso a análise crítica desde o momento do diagnóstico é fundamental, pois sem preceber problemas, limites, resistências, dificuldades, potencialidades e oportunidades é muito difícil propor estratégias adequadas.

Marília era uma faculdade pequena, sem muitas tradições, com poucos níveis hierárquicos, baixo grau de formalidade e com poucos núcleos de poder além do que estava organizado ao redor da direção. Nesse caso, a busca por alternativas e a necessidade de mudar foram fortemente reforçadas pela violenta crise institucional. Mudar ou fechar: assim a questão estava colocada. Tipicamente, então, houve uma forte concentração de poder em mãos da direção da faculdade e do projeto, seguida de forte legitimação dessa mesma direção e de suas propostas em função da conquista da estadualização.

Desse modo, apesar de as coisas haverem começado a partir de um patamar de menor acumulação, o que tornou o processo inicial mais lento, foi possível desencadear a mudança mais rapidamente (aproveitando a necessidade de adequação da instituição às normas estaduais) e com grande radicalidade, demonstrada pela extinção dos departamentos e pela mudança de toda a normatividade acadêmica em consonância com os princípios da nova proposta.

O curso de medicina de Londrina articula docentes de vários Centros, está inserido em uma universidade, que é uma instituição maior, mais complexa, com dinâmica e instâncias de decisão bem estabelecidas. A UEL é uma universidade com bom prestígio, alguma tradição de investigação e líder na região. Por conta dessa complexidade e dessa história, havia vários núcleos de poder construídos com base no poder técnico e político. Além do mais, o curso tradicional, apesar de todos os seus problemas, era socialmente considerado de boa qualidade. Por todas essas características, o processo de negociação para - e a própria construção da a mudança - necessariamente tinham que ser mais complexos e lentos. 
A eleição que, no início dos anos 90, levou à direção do CCS forças favoráveis à mudança (eleitas com essa plataforma e representadas pela dupla diretor da Saúde Coletiva e vice da enfermagem) foi muito disputada; o resultado foi garantido pelo voto dos estudantes. Como comentado, essa oposição se manifestava já à própria adesão à proposta UNI e houve todo um esforço para diminuir resistências e abrir espaços de negociação. Foi assim que o candidato derrotado nessas primeiras eleições aderiu ao UNI e foi o candidato de consenso (com uma vice da Saúde Coletiva) nas eleições seguintes.

Apesar de todas as estratégias desenvolvidas para mobilizar e sensibilizar os docentes, ao momento da decisão da mudança ainda havia uma oposição não desprezível e bem caracterizada. Ainda assim, através da grande mobilização da maioria dos docentes e dos estudantes em torno da proposta inovadora, foi possível aprovar e implantar a proposta inovadora. A força mobilizada a favor da mudança foi suficiente para impedi que houvesse um confronto (ninguém votou contra a proposta, nem apresentou uma outra alternativa), mas a existência da oposição tornou necessário que se fizessem concessões.

A necessidade de acumular poder e mobilização a favor não se encerra a partir da implementação da mudança. Ao contrário. Em qualquer processo de transformação, durante o periodo de implantação é fundamental assegurar bons resultados, abrir espaços de escuta, identificar e resolver os problemas que surjam. Em primeiro lugar, pela grande insegurança gerada pela adoção de um modelo que rompe com os valores tradicionais: a todo tempo os coletivos e os indivíduos são assaltados por dúvidas, as exigências por resultados são muito maiores etc. Em segundo lugar porque é fundamental continuar acumulando poder e mobilização e os espaços de reflexão crítica são fundamentais para isso.

Nos dois casos analisados, inicialmente os novos espaços de participação constituídos, os novos papéis desempenhados, o fato de docentes e estudantes passarem a ser sujeitos dos processos foram motivo de muito entusiasmo, satisfação e, conseqüentemente, de fortalecimento da nova proposta. 
Outro elemento fundamental para a acumulação de poder e legitimidade são as formas organizativas adotadas, que têm que ser coerentes com o conteúdo da inovação proposta. Uma mudança como a implementada, que implica a democratização das relações internas e compromisso com os problemas sociais, tem necessariamente que estar sustentada em formas organizativas democráticas.

Além do mais, o novo é construído através de aproximações sucessivas porque a construção da mudança coloca muitas perguntas ainda sem resposta e porque, mesmo num processo profundo de mudança, há uma tendência de reprodução das práticas tradicionais. Portanto, é preciso manter os espaços de participação, continuar com o processo de capacitação e de reflexão crítica sobre as práticas para garantir a consistência e a coerência do processo. Além disso, como a implantação vai revelando novos desafios, que, ao serem enfrentados, vão gerar novas oposições e resistências, novas estratégias para ganhar novas adesões e circunscrever a oposição são fundamentais.

Nos dois casos houve problemas em relação a esse aspecto, pois, em função do intenso tabalho necessário à implantação, houve uma tendência de redução dos espaços coletivos de reflexão organizada aos momentos anuais dos grandes fóruns de avaliação. Houve também limitada capacidade de produzir novas estratégias, como no caso da preparação do terreno para a implantação das mudanças no internato, que ainda não conseguiram acontecer.

Em Marília houve, no entanto, um trabalho de identificação permanente dos problemas, dos novos limites e possibilidades da mudança através da avaliação. $O$ produto desse trabalho, compartilhado com os docentes, alimenta o debate nos fóruns de avaliação anualmente realizados, possibilitando uma análise mais profunda do processo de mudança. Apesar de não haverem sido ativadas as novas instâncias de deliberação e participação (os colegiados de curso), houve um espaço de escuta e negociação permanente com os docentes que se constituiu através do processo de capacitação (que também levou sempre em conta os resultados da avaliação). 
Esses dois mecanismos foram suficientes para seguir consolidando a adesão entre os docentes e fortalecer a legitimidade do grupo condutor. Entretanto, abriuse um vazio nas relações com os estudantes, para quem os espaços existentes de negociação cotidiana foram insuficientes, insatisfatórios. Como resultado, dúvidas e insatisfações geraram desconfiança em relação à capacidade do núcleo de direção atual, fato que foi rapidamente capitalizado pela oposição no momento das últimas eleições.

Em Londrina toda a energia foi investida no trabalho da implantação, o que, aliado à falta de direção estratégica, levou a que não se criassem oportunidades de reflexão crítica organizada sobre as novas práticas. Problemas crônicos de infraestrutura associados à falta de construção de capacidades no terreno da avaliação impediram que o processo avaliativo (da implantação) cumprisse o papel de alimentação crítica do processo de mudança. Além disso, a falta de estratégias adequadas para propiciar a adesão dos clínicos limitou os avanços na implantação do quarto ano e contribuiu para que até o momento não tivesse sido possível mudar o internato.

A greve de quase seis meses (ocorrida desde setembro de 2001 até março de 2002) deixou esses problemas e disputas adormecidos. Mas trouxe outros à tona: os que eram contra ou a favor da greve, contra ou a favor desta ou daquela solução; o desgaste por uma tão prolongada paralisação, compensado por uma vitória ao final. Certamente houve rearranjo de forças e de intenções. Um novo mapa terá está sendo construído em função das eleições para todos os cargos e em todos os níveis - a começar pelos departamentos e colegiados de curso, seguidos pelas eleições para a reitoria, hospital universitário e finalmente para a direção do CCS (esta no segundo semestre).

Até o momento (maio de 2002), os resultados das eleições para as chefias de departamentos e colegiados foram positivos. Há muita mobilização para a construção da proposta para concorrer ao PROMED e os debates se estão dando em torno das melhores estratégias para superar os problemas (por todos) 
identificados, decorrentes do (des)governo dos últimos anos. Revitalização do processo de capacitação docente e da avaliação, criação de espaços de debate e reflexão crítica, novas estratégias para conquistar a adesão dos clínicos e implantar mudanças no internato, fortalecimento dos PINs etc.

Assim são os processos de mudança: uma luta permanente pela construção do novo e uma disputa permanente entre as novas alternativas e as velhas soluções. A falta de uma direção estratégica leva à perda de poder, mesmo que ele tenha sido suficiente um dia para começar a enfrentar os desafios, e pode colocar em risco a consolidação da mudança. O saber e a experiência acumulados e existência de uma massa crítica constituída permitem, entretanto, a reversão de situações desfavoráveis a partir da utilização de estratégias adequadas.

\subsubsection{O mapa dos atores}

Uma proposta de mudança necessariamente produz reações e ações dos grupos sociais afetados (ou que se considerem afetados) negativamente por ela. Por isso a análise de sua viabilidade inclui uma identificação dos grupos de interesse existentes, dentro e fora da escola, que serão potencialmente mobilizados por ela. Ou seja, exige uma análise da configuração dos grupos de poder dentro do campo de forças que se configura em relação a essa questão.

Em primeira instância, o critério para identificação das posições e interesses está relacionado com a inserção de cada indivíduo no processo produtivo e, portanto, com o sujeito ideológico. Segundo esse critério, um sujeito se autoconstruirá como biologista na medida que a forma organizativa do seu processo de trabalho - enquanto trabalho abstrato - impulsione-o nessa direção. Esse seria um exemplo de pré-consciência (TESTA, 1995).

Existe também uma consciência corporativa, que leva o indivíduo a identificar-se e mobilizar-se pela defesa dos interesses de sua corporação. Ilustrativo é o exemplo das entidades corporativas dos médicos que se opõem a 
todas as políticas de reorientação do mercado que possam levar a uma reorganização do sistema de poderes dentro da categoria.

Em alguns casos, apesar de haver diferenças de interesse entre distintos membros de uma corporação, o conjunto se mobiliza em defesa da manutenção do status quo. É o caso dos médicos assalariados que continuam se identificando com um ideal de prática liberal (mesmo que ele não tenha correspondência com a realidade) e se posicionam diante das questões concretas segundo esse ideal, fortalecendo o domínio polítco e ideológico de uma fração da corporação sobre seu conjunto.

Além desses referentes, individuais e coletivos, a defesa dos micropoderes contrariados também é outro determinante do posicionamento de pessoas e grupos diante de uma proposta de mudança.

Mas esses não são os únicos critérios para a definição das posturas individuais. Como vimos, várias modalidades de experiências práticas e de exercício de reflexão crítica podem levar a outro tipo de posicionamento, ou seja, de crítica e não de reprodução da ordem hegemônica.

$\mathrm{Na}$ verdade o mapa serve mais para tentar caracterizar o que define a identidade de grupo de determinado profissional para, então, traçar estratégias que possam levá-lo a uma reflexão crítica sobre sua prática e a uma mobilização em favor da mudança.

O contexto atual de crise e insatisfação generalizada - dos docentes com a prática tradicional docente, dos médicos com as condições em que são obrigados a trabalhar, da população diante da qualidade insatisfatória dos cuidados que recebe, dos serviços diante da baixa eficiência e resolubilidade da prática profissional fragmentada e excessivamente tecnificada - abre muitas possibilidades de problematização e sensibilização em direção a alternativas mais democráticas e satisfatórias.

Nos dois casos estudados havia consciência clara de que uma proposta de mudança do processo de formação dos médicos não poderia ser construída nem 
implementada a partir de departamentos isolados e sem contar com a participação dos docentes da área clínica (em sentido amplo).

Nos dois casos, o primeiro problema enfrentado, logo quando da decisão de postular a participação no programa UNI, foi que era exatamente a área da saúde coletiva (ou da medicina preventiva) a que concentrava certas capacidades e saberes necessários à elaboração da proposta e à sua implementação inicial. Como, então, aproveitar essa capacidade sem circunscrever o projeto, sem caracterizá-lo como "da preventiva" ou da "saúde coletiva"? A solução foi iniciar, desde esse momento, o exercício de identificação dos pontos sensíveis, capazes de gerar a mobilização de um contingente maior de docentes em favor de repensar alternativas à formação tradicional.

Como já comentado, em Londrina, para diminuir as resistências e desconfianças dos professores da área clínica, em relação ao projeto UNI e às propostas de mudança, foi feito um trabalho de convencimento de um de seus líderes, que terminou aderindo à proposta e encabeçando uma chapa de coalizão à direção do Centro (e do projeto UNI). Essa solução funcionou num primeiro momento, pois se abriram novos espaços de negociação e de conquista de adesões. $\mathrm{Na}$ continuidade, sem o desenvolvimento de estratégias específicas de sensibilização, voltou-se a perder espaço.

Em compensação, as estratégias do PEEPIN, PAPS e PAPIENS haviam sido excelentes para a sensibilização dos professores da área básica e também um mecanismo eficiente de capacitação em metodologias ativas de ensinoaprendizagem. Eles, que em outras escolas se opõem radicalmente às mudanças, em Londrina se converteram em grandes defensores e principais implementadores da mudança num momento inicial.

Em Marília, o diretor da faculdade e do projeto UNI era originalmente da área de medicina preventiva, assim como vários dos participantes do núcleo condutor. No entanto, logo nos primeiros anos de implementação do UNI ocorreu um conflito, que acabou colocando a maior parte dos componentes da Medicina 
Preventiva em uma postura de oposição sistemática à direção e ao processo de mudança.

Como conseqüência, o núcleo condutor teve que construir a nova proposta trabalhando especialmente com os professores da área clínica e obteve boas respostas. Atualmente, vários dos integrantes do grupo condutor são docentes de 40 horas, mas que mantêm atividade de prática clínica privada ao final do expediente na escola. Realmente, o primeiro momento em que os interesses corporativos (dentro desse grupo) falaram mais alto que a nova "consciência pedagógica" foi quando da reorganização da lógica do hospital (que foi interrompida).

Todo o tempo ocorrem novas adesões, bem como conflitos e disputas de poder - que podem levar ao rearranjo de forças e posições. Mesmo neste momento de consolidação, portanto, o mapa dos atores, de seus interesses, limites e possibilidades é fundamental para que se possam desenvolver novas estratégias adequadas ao avanço das mudanças.

\subsubsection{A capacidade de mobilizar e de envolver atores externos à universidade} no processo de mudança no espaço local: a parceria com os serviços e com os representantes da comunidade

A parceria, entendida como uma modalidade de co-gestão, também foi muito importante dentro da construção dos processos de mudança e pôde cumprir pelo menos dois papéis, fundamentais e estratégicos: funcionar como elemento de sustentação política para a mudança e como espaço social para a constituição de sujeitos.

Parte-se do pressuposto de que se trata de uma articulação entre três atores muito diferentes entre si; atores que operam de acordo a lógicas distintas, em tempos diferentes, com diferentes graus de acumulação de poder. No entanto, há possibilidades de estabelecer uma agenda de interesses comuns. 
Em função da história do setor saúde no Brasil, existe uma construção prévia, que leva ao reconhecimento da importância da ação estratégica articulada que está presente na memória (individual ou coletiva) e na prática de construção do SUS; história essa de que todos os atores envolvidos no UNI são participantes. A agenda comum a ser construída pode ser mais ou menos abrangente e envolver maiores ou menores compromissos. Isso depende da maneira como cada ator concreto encara essa articulação específica, em termos da compreensão política e do valor que atribui a ela dentro dos seus respectivos projetos políticos. Orientações partidárias e o rodízio de partidos no poder municipal, bem como o nível de organização prévio da comunidade também interferem claramente na dinâmica e no potencial dessa relação.

A parceria opera pelo menos em dois níveis: o político e o operacional. Quando todos os atores valorizam o potencial da articulação, é possível produzir impactos importantes nos dois níveis. A co-gestão pode ser estabelecida em torno da questão da formação e capacitação de pessoas, de acordo com os interesses e necessidades de cada parceiro. Pode haver co-gestão das atividades compartilhadas em todas as esferas da atenção. De qualquer modo é no nível operacional, ou seja, no espaço da prática, que se estabelecem os espaços coletivos para a construção conjunta de sentidos, essencial para a constituição dos sujeitos sociais. E essa ação articulada no nível operacional pode ser mantida e operada até mesmo quando há situações menos favoráveis no nível político.

Em Marília, num primeiro momento, a secretaria de saúde não tinha interesse em promover mudanças, em avançar na implantação do SUS, mas permitia que os profissionais das unidades participassem livremente das atividades e articulações propostas pela universidade e pelos serviços. Num segundo momento, a secretaria identificou o projeto como parte de suas atividades estratégicas e passou a reconhecer no trabalho articulado um potencial importante de colaboração na mudança do modelo de atenção e na educação permanente dos profissionais da rede. 
Na faculdade, por seu lado, a direção tinha compromissos com a construção do sistema de saúde, identificava na parceria a possibilidade de ampliar seus compromissos nessa área e tinha poder sobre todos os equipamentos de saúde da faculdade. Logo na primeira fase do UNI, o centro de saúde - escola foi repassado à rede municipal e na segunda fase o Hospital das Clínicas foi totalmente integrado à rede, tanto como retaguarda no atendimento ambulatorial de especialidades como na área de internação, que está submetida à central de vagas do município.

Há que se ressaltar também algumas características particulares. O secretário da saúde nos dois últimos governos municipais foi sempre o mesmo; é professor da faculdade, comprometido com a construção do projeto político da mudança e com fortes relações políticas com o grupo que está à frente da faculdade. A comunidade era e segue sendo pouco organizada e tem poucas possibilidades de interferir efetivamente no processo.

Como resultado, a parceria entre universidade e serviços ocorre tanto no nível político como no operacional. São tomadas decisões de parte a parte que facilitam os processos de mudança tanto na graduação como na organização do modelo de atenção; a participação ativa e coletiva de docentes e profissionais dos serviços, em vários momentos, continua levando à construção de compromissos com a qualidade, que aumentam a relevância social das duas instituições. No entanto o conteúdo dessa relevância tem sido construído com débil participação da população (fortalecida recentemente através da ação dos agentes comunitários de saúde), o que potencialmente limita seu alcance.

Em Londrina a secretaria de saúde nunca esteve totalmente interessada na parceria. Num primeiro momento e no atual existe uma coincidência de propósitos entre o programa de governo e o projeto, o que facilita a realização de atividades conjuntas. Mas, a secretaria não identificava então e até recentemente não identificava, um potencial estratégico nessa articulação de parceria. Um potencial de fazer diferença, de produzir impactos positivos na concretização de suas 
próprias propostas. Nos últimos meses, em função das negociações abertas em torno do PROMED e das propostas de educação permanente, pela primeira vez a secretaria dá mostras de interesse estratégico na parceria - o que certamente pode ser uma vantagem estratégica para o próximo período de trabalho.

No momento intermediário, na gestão municipal anterior, a secretaria de saúde era contra o projeto e, com muito esforço de negociação e de mobilização de forças extra-CCS (vice-reitoria) e extra-universidade, foi possível manter articulado o trabalho com os níveis intermediários e de base, ou seja, diretamente com os profissionais de saúde da rede.

Como conseqüência, até o momento, a parceria entre serviços e universidade não possibilitou nunca a possibilidade de saltos de qualidade em nenhum dos dois terrenos.

A comunidade é muito organizada e inteiramente comprometida com a proposta da parceria e com o projeto - que lhe possibilitou fortalecimento das organizações, ampliação da participação e conquista de legitimidade política cada vez maior dentro e fora da cidade. Em alguns momentos, foi a única parceira a sustentar a articulação. Foi capaz de conquistar espaços de participação tanto na esfera da academia como dos serviços, os quais ocupa de maneira bastante ativa e propositiva.

A direção do CCS valoriza a parceria, historicamente há um compromisso institucional com a construção do SUS, mas seu poder sobre os equipamentos de saúde da universidade é limitado. No início do projeto as três unidades básicas de saúde que eram mantidas pela universidade foram integradas à rede. $\mathrm{Na}$ continuidade, não houve a capacidade (ou interesse) de inserir a direção do hospital no processo de construção da parceria, o que restringiu o âmbito da articulação. $O$ espaço da atenção básica, portanto, tem sido o terreno da concretização da parceria, já que a inserção do Hospital Universitário e do Ambulatório de Especialidades na rede é muito limitada. 
Como resultado há uma relação muito intensa e produtiva na base, entre os profissionais da universidade, dos serviços e as pessoas e organizações da comunidade e momentos de participação conjunta para o enfrentamento de problemas (muitas vezes identificados e propostos pelas organizações comunitárias). Há processos de cooperação no âmbito da educação permanente, mas articulados de modo pontual. Existe uma articulação quase que formal na cúpula, o que torna muito lentos os processos de negociação para o trabalho

conjunto. Apesar disso em vários momentos de conflito, a articulação (especialmente entre universidade e comunidade) tem sido potente para garantir o enfrentamento de problemas.

Mas é inegável, apesar das diferenças de qualidade e abrangências das relações (que aumenta ou diminui sua força estratégica), que o cenário local passou a fazer parte da agenda das faculdades. Até porque as atividades articuladas são parte integrante de seu trabalho cotidiano, habitual, institucional.

\subsubsection{A capacidade de mobilizar e de envolver atores externos à universidade no processo de mudança no espaço global}

Não se trata aqui de voltar a discutir a compreensão a respeito das relações de determinação e condicionamentos que a estrutura econômica e a organização político-social exercem sobre qualquer proposta, projeto ou programa de mudança. Trata-se, sobretudo, de identificar a compreensão que os atores dos projetos UNI de Marília e de Londrina tiveram a respeito das influências do cenário sobre os respectivos processos e como reagiram a isso.

Ao longo do tempo, como já foi comentado, a parceria começou a ser compreendida de maneira mais estratégica, como possibilidade de ampliação dos recursos de poder, através da construção de alianças dentro e fora das escolas (ALMEIDA, 1999). 
Como apresentado no capítulo sobre os UNI e a Rede UNIDA, a percepção sobre a complexidade da mudança que se buscava construir, bem como o impacto dos condicionamentos externos (positivos e negativos) sobre os processos locais, foi ocorrendo ao longo do tempo.

Foi ficando claro que para construir cenários favoráveis à mudança, tanto para que ela pudesse ocorrer em muitas outras escolas, como para garantir sua sustentabilidade em cada contexto local, era necessário atuar na esfera das políticas, mover forças mais poderosas. Somente assim seria possível reunir a força necessária para (aumentar a chance de) levar as mudanças às últimas conseqüências. Somente assim os projetos poderiam (aumentar a chance de) construir mudanças sustentáveis. Somente assim poderiam contribuir efetivamente para mudar os cenários da formação e da prática dos profissionais de saúde.

Em conseqüência, mudou a compreensão a respeito da construção da governabilidade necessária para a implementação dos projetos e também a respeito do espaço em que se inscrevia sua ação. Para analisar a estratégia adotada pelos projetos UNI para enfrentar esse novo desafio, será necessário retomar alguns conceitos relacionados com os espaços sociais em que se constroem as ações estratégicas, que foram desenvolvidos por Mario Testa (1995).

Segundo ele, há dois espaços nos quais se discutem políticas (com significados distintos): o setorial e o global. No espaço setorial se discute e disputa a definição ideológica dos conteúdos e proposições setoriais; no espaço global se discutem e tomam as decisões políticas. Ou seja, somente no momento em que um tema transcende o espaço setorial e ganha o espaço do Estado é que se pode converter em política social.

O setor saúde em determinado momento é a combinação articulada de todos os campos de força gerados pelas questões relacionadas à saúde. Isso porque cada problema em discussão na sociedade gera seu campo de forças, ou seja, mobiliza a ação de determinados sujeitos interessados. Por ser um espaço social, 
ele se redefine permanentemente, tanto em termos conjunturais, quanto históricos, como espaço em que se disputa o poder cotidiano e como espaço em que se disputa o poder social geral. Portanto, a estrutura de poder do setor é gerada em sua articulação com o Estado.

Para influir nas políticas públicas - e fortalecer os condicionamentos favoráveis ao desenvolvimento de seus processos locais de mudança - os projetos UNI precisavam construir a capacidade de inserir o debate dos temas que thes interessavam no espaço global, mobilizando o poder político necessário para tomar as decisões correspondentes.

Para tanto, seria necessário convencer ou agregar muitas outras forças, para além das que já estavam articuladas em torno da mudança da formação profissional em saúde, em torno dos referidos temas, já que somente assim seria possível atingir o "nível crítico" indispensável para colocar uma questão em pauta.

O caminho percorrido pelos projetos UNI, e depois pela Rede UNIDA, revela compreensão dessa necessidade e um olhar estratégico sobre como atuar. A decisão de integrar-se à Rede IDA e depois de ampliar sua composição, incluindo "pessoas, projetos e instituições interessadas na mudança da formação de profissionais de saúde para o fortalecimento do SUS", a um tempo revela uma estratégia de ampliação, de articulação com outros sujeitos sociais em torno a um propósito comum e também demonstra a compreensão que tinham do contexto ( e a leitura de quem seriam seus principais aliados), quando identificam a construção do SUS como temática fundamental para orientar a mudança na educação.

Como reúne pessoas, projetos e instituições que estão diretamente envolvidas na construção de mudanças (maiores, menores, pontuais, abrangentes, mais superficiais e mais profundas), foi possível para a Rede construir seu discurso com base na reflexão sobre experiências práticas. Reflexão essa que foi construída de maneira coletiva através dos seminários de sistematização.

Além disso, a Rede buscou ter presença em todos os fóruns possiveis relacionados à saúde, procurou divulgar suas experiências e propostas e 
contribuir para o enfrentamento de problemas relevantes do contexto (no campo da formação e da construção do SUS, baseados nas experiências reais) (COSTA et al, 2000). Esses foram, sem dúvida, elementos para a qualificação de seu discurso dentro do cenário setorial e para sua legitimação enquanto ator social que "tinha o que dizer" a respeito dos caminhos para a mudança da formação dos profissionais de saúde.

Quando finalmente a questão da mudança da formação dos profissionais de saúde começou a entrar na pauta no espaço global, a Rede, como ator coletivo, teve a possibilidade real de influir na definição de algumas políticas, como foi o caso das diretrizes curriculares e do programa de incentivo às mudanças nos cursos de medicina lançado pelo Ministério da Saúde.

\subsection{As mudanças}

Nesta seção vão ser analisadas as mudanças de Marília e de Londrina sob o ponto de vista do projeto político-pedagógico adotado, das relações que se estabeleceram entre os atores sociais envolvidos no processo de produção dos médicos e dos processos relacionados à construção do saber médico.

\subsubsection{O ideário UNI e as mudanças de Londrina e Marília}

Existem muitos aspectos de identidade entre as propostas construídas em Marília e em Londrina. A influência da proposta do programa UNI em termos da concepção geral e dos principais temas da mudança é evidente. Numa formulação sintética, essas diretrizes gerais resumem-se em 6 pontos principais (CHAVES et al, 1999):

“a) a educação das profissões da saúde deva ser relevante, orientada para os problemas de saúde da sociedade;

b) mais explicitos quanto às competências a serem adquiridas para o bom exercício profissional; em outras palavras, que o perfil do profissional que se quer formar seja descrito com clareza e 
detalhe;

c) que o ensino interdisciplinar deva ser estimulado, articulando teoria e prática, conteúdos básicos e clínicos, integrando os aspectos biopsicossocias;

d) que a aprendizagem em unidades de saúde da universidade, hospitalares ou ambulatoriais, seja complementada com a aprendizagem em cenários da vida real tanto dos serviços como da comunidade;

e) que é necessária uma modernização didática, com diminuição do ensino em aulas teóricas, $e$ introdução de novas metodologias de ensino tais como ensino tutorial e em pequenos grupos, aprendizagem baseada em problemas $(A B P)$, e estudo auto-dirigido;

f) que se enfatize a investigação aplicada, e que ela seja sempre que possível participativa, quando envolve a comunidade".

O ideário, portanto, continha indicações claras a respeito dos caminhos que se devia trilhar para produzir as mudanças na universidade. Estavam expressos todos os elementos fundamentais do que se espera das mudanças na educação dos profissionais de saúde (não somente dos médicos). No entanto, não estava claramente explicitada a profundidade necessária das mudanças para que de fato contribuíssem para transformar o perfil do profissional formado e para a uma ruptura com as concepções tradicionais de educação e com os limites do racionalismo na produção de conhecimentos.

O ideário UNI, isso já foi comentado, era genérico em vários aspectos - por problemas decorrentes de sua matriz teórica híbrida e também por limitações históricas concretas, pois havia questões para as quais não se tinha resposta à época de sua elaboração.

O acadêmico foi um terreno em que a indefinição do ideário cumpriu duplo papel. Por um lado, ao início do programa, seria muito complicado assumir a necessidade ou o compromisso com uma mudança profunda. Complicado, precoce e inviável.

No início dos projetos não estava absolutamente clara qual seria a tradução prática da articulação de todas as inovações propostas, tampouco estavam dadas 
as condições em termos de correlação de forças (de sujeitos mobilizados em torno da idéia da mudança), para que uma proposta claramente transformadora fosse assumida como meta.

Além do mais, de modo geral, o programa indicava pistas, orientações gerais, não estabelecia um resultado definido a priori a que se deveria chegar através dos projetos. Isso porque se considerava que em função da extrema diversidade, cada qual, explorando a seu modo as estratégias e proposições propiciadas pelo ideário, chegaria a algum lugar, mais ou menos próximo da mudança de perfil e de concepções almejada.

A ambigüidade da formulação original, portanto, era inevitável (porque não estava clara, nem pronta a proposta de mudança), necessária e correta (porque a indefinição possibilitou a mobilização de amplas forças a favor da mudança e porque os projetos tiveram liberdade suficiente para construir suas próprias alternativas).

No entanto fez falta problematizar esses conteúdos ao longo do tempo. Perguntar dentro de cada projeto se haviam chegado onde queriam, se o resultado de todas as inovações introduzidas era a formação de um profissional com um novo perfil. Se não era, então como fazer para chegar lá?

Nos caminhos percorridos para construir a mudança, como vimos, houve ênfase maior em uns aspectos que em outros: a crítica à concepção pedagógica tradicional articulada com a exploração de várias metodologias ativas de ensinoaprendizagem; a crítica ao ensino centrado no hospital articulada a muitas experiências de diversificação de cenários de ensino-aprendizagem; a crítica à concepção biologista articulada com tentativas de incorporar o social à prática e às preocupações dos estudantes especialmente em suas atividades nos cenários comunitários e nas unidades básicas de saúde; o estimulo à realização de investigações em parceria com os profissionais dos serviços e com a comunidade; crítica à fragmentação dos conteúdos articulada ao estímulo de experiências interdisciplinares; a crítica à desarticulação entre teoria e prática articulada ao 
estímulo à realização de atividades práticas desde o início da carreira; o estímulo ao trabalho multiprofissional através de experiências de práticas articuladas entre as várias carreiras.

Ou seja, os pontos fortes da mudança atual correspondem ao campos nos quais houve desenvolvimento de estratégias, acumulação de experiências e de pensamento crítico. As estratégias de sensibilização e mobilização endereçavam problemas críticos, seguramente alvos do processo de mudança que se queria desencadear no futuro, mas o que determinou sua implementação e seu sucesso foi sua capacidade de mobilizar, mover, atingir docentes e estudantes. $O$ objetivo principal dessas estratégias, portanto, era constituir grupos com capacidade de proposição e reflexão críticas e acumular recursos de poder a favor da mudança.

Não havia como ser diferente, pois a tarefa fundamental era constituir grupos consolidados de apoio à mudança, já que caso não se constituísse essa base de sustentação para a mudança, ela poderia não ocorrer ou ocorrer mas ter uma base de apoio muito frágil e vulnerável (TESTA, 1995).

De certo modo e em certo grau, portanto, as características da primeira fase, do período de acumulação de forças para a mudança, influem no conteúdo inicial da mudança implementada. Ou seja, tanto os pontos fortes como alguns dos problemas e limitações atualmente identificados nos processos de Marília e de Londrina foram produto, ou seja, condicionados pelo desenho das estratégias que foram utilizadas para a construção das próprias mudanças. Essa é uma contingência inevitável, mas importante de ter em conta.

A construção de novas práticas e de novos conteúdos em Londrina e em Marília foi feita de maneira participativa (o que é fundamental) e processos participativos sempre são processos de aproximações sucessivas (refletem o nível de acumulação de experiências e conhecimentos de um dado coletivo em um dado momento). Avança-se até onde é possível (geralmente parece que se está fazendo o máximo), daí, na prática e através da reflexão sobre a prática, são descobertos os limites da proposta construída e identificados novos desafios. 
Ou seja, sempre vai haver limitações conceituais e vazios estratégicos, sempre há problemas importantes que não foram endereçados e novas questões que só se revelam importantes ao longo do processo. Mas não há problema: se os grupos mobilizados são críticos e reflexivos, ao longo da implantação da mudança serão capazes de enfrentar novos desafios e partir para novas experiências, superando as limitações da formulação inicial. Isso é possível, é claro, desde que ao longo da implantação da mudança se mantenha a atividade de avaliação crítica e de debate permanentes para identificar e buscar superar problemas e fragilidades.

\subsubsection{O projeto político-pedagógico}

Nos dois casos, de fato, foram debatidos os temas amplos que configuram um projeto político-pedagógico: o perfil do profissional a ser formado, os papéis da escola médica em relação à sociedade, a concepção pedagógica, o papel dos docentes e dos estudantes no processo de ensino-aprendizagem, os cenários de ensino e de prática, a integração dos conteúdos, a articulação entre teoria e prática , etc. Ou seja, de fato foram construídos projetos político-pedagógicos e de fato se pretendeu fazer (e se fizeram) mudanças profundas no processo de produção dos médicos.

É evidente também que se estava propondo uma mudança que endereçava a relevância social da escola médica e uma mudança radical da ordem estabelecida em termos das relações internas e das relações externas estabelecidas no processo de formação dos médicos.

Destaca-se sempre que, à diferença de outros currículos organizados com base na aprendizagem baseada em problemas, as propostas de Marília e de Londrina incluem um módulo/unidade que é longitudinal (ao longo de todo o ano) e transcurricular (do $1^{\circ}$ ao $4^{\circ}$ ano), em que os estudantes têm a oportunidade 
de trabalhar sobre problemas reais, identificados pela comunidade ou pelos serviços de saúde, desenvolvida com base na metodologia da problematização.

Explicitamente, portanto, a concepção pedagógica adotada é híbrida. Uma concepção pedagógica predomina na orientação do processo de ensinoaprendizagem que se realiza através dos módulos e das habilidades e outra concepção pedagógica predomina na orientação do processo de ensinoaprendizagem que acontece nos PINs e na Interação Comunitária.

A metodologia da aprendizagem baseada em problemas foi criada por professores da Universidade de MacMaster, Canadá, no final dos anos 60 e depois foi adotada e desenvolvida (com modificações) em várias outras escolas médicas do mundo. Nos textos escritos pelos autores da proposta não há referências às bases conceituais da proposta, ou seja, ela foi desenvolvida empiricamente.

Nessa época, crescia no mundo a contestação sobre a concepção pedagógica tradicional, especialmente no campo da educação de crianças. O primeiro desses movimentos foi a Escola Nova, que propunha que a educação fosse instigadora da mudança social e ao mesmo tempo se transformasse porque a sociedade estava em mudança. John Dewey, um dos primeiros formuladores do novo ideal pedagógico afirmava que o ensino deveria dar-se pela ação e não pela instrução. Para ele, a educação continuamente reconstruía a experiência concreta, ativa, produtiva de cada um. A educação por ele preconizada era essencialmente pragmática: buscava a convivência democrática sem colocar em questão a lógica da organização social (GADOTTI, 1998).

$\mathrm{Na}$ esteira dessa corrente, Piaget estudou o desenvolvimento da inteligência da criança e propôs que a educação deveria respeitar os diferentes momentos desse processo. Segundo ele o papel da ação é fundamental na aprendizagem, pois o pensamento lógico é essencialmente operatório, ou seja, ele prolonga a ação através de sua interiorização.

Por essa razão, ele propõe que os métodos ativos são essenciais no processo de aprendizagem da criança e do adolescente, pois compreender é inventar ou 
reconstruir através da reinvenção. Segundo Piaget, o professor deve cumprir o papel de estimular, de criar situações e armar os dispositivos iniciais capazes de suscitar problemas úteis às criança; deve também organizar contra-exemplos que levem à reflexão e obriguem à revisão das soluções apressadas (PIAGET, 1988).

A crítica à educação tradicional ensejada pela Escola Nova culminou com a pedagogia antiautoritária, com correntes liberais e também marxistas, que afirmavam a liberdade como princípio e objetivo da educação. Summerhill é um exemplo de escola libertária. Neill, sob a influência de Rousseau e Reich, propunha a educação sem violência, através da qual a criança em plena liberdade - sem uma direção autoritária, ameaças e coação - conhecendo o limite e o direito da liberdade do outro, transformar-se-ia em um homem bom (GADOTTI, 1998).

Rogers foi outro representante da escola libertária e propunha que o processo educativo estivesse centrado na criança e não no professor, nem no conteúdo programático. Os princípios básicos do processo de ensinoaprendizagem seriam a confiança nas potencialidades humanas, a pertinência do assunto a ser aprendido, a aprendizagem participativa, a autoavaliação e a autocrítica e a aprendizagem da própria aprendizagem. $O$ objetivo da educação seria ajudar os alunos a se converterem em indivíduos capazes de ter iniciativa própria para a ação e que fossem responsáveis por suas ações. O professor seria um facilitador da aprendizagem, que seria tanto mais profunda quanto mais importante para a totalidade da pessoa. Ou seja, quando o estudante percebe que o assunto a estudar se relaciona com seus próprios objetivos (aprendizagem significativa) (GADOTTI, 1998).

O movimento da Escola Nova foi se construindo junto com a escola moderna, científica e pública, recebendo influências tanto do marxismo como do positivismo, daí ser um movimento complexo e contraditório. Essa corrente teve grande influência sobre o pensamento pedagógico no Brasil. As escolas ativas, as escolas experimentais, os colégios de aplicação, as escolas livres, as escolas 
comunitárias, que surgiram por aqui na década de 60, são exemplos disso (GADOTTI, 1998).

Ainda que os autores da proposta da Aprendizagem Baseada em Problemas não tivessem feito uma opção consciente por uma corrente metodológica, parece claro que os debates que predominavam à época tiveram influência decisiva em suas opções. Pode-se dizer que a Escola Nova é a base conceitual da Aprendizagem Baseada em Problemas. Se Dewey ou se Rogers, depende mais de quem esteja desenvolvendo a proposta. A essência da proposta é reconhecer que a aprendizagem é um processo ativo, baseada no enfrentamento de problemas, que deve estar centrada nas necessidades de aprendizagem do estudante (não importando se são problemas reais ou não, o que importa é o desafio, o estímulo que o problema representa para o estudante).

A outra vertente é a da concepção crítico-reflexiva, que articula ação, reflexão (produção de conhecimento) e ação transformadora; ou seja, a produção do conhecimento se dá através da reflexão sobre a prática em um cenário real. A problematização, cujo principal representante no Brasil é Paulo Freire, é uma das metodologias que se inscreve nesse campo.

Segundo Freire, são as razões do estudante que definem o mote ou o caminho da aprendizagem, mas não basta que o assunto seja significativo só para o aluno enquanto indivíduo; é preciso que seja significativo para o planeta (porque é fundamental que o estudante possa estabelecer relações e que a educação sirva para o despertar do cidadão); além disso, aprender a aprender é a razão de ser do próprio objeto que se quer aprender (então é preciso não ficar restrito às primeiras percepções sobre um problema, ou seja, sair do senso comum e partir para o conhecimento elaborado); o aluno só aprende quando se envolve profundamente com a situação; a educação deve levar o estudante a pensar criticamente e a ser capaz de analisar a realidade (BERBEL, 1999).

A influência de Paulo Freire, especialmente na educação de adultos, foi enorme no Brasil. Foi a problematização a metodologia utilizada no Programa 
Larga-Escala, que foi levado a cabo em todo o país para a formação de atendentes de enfermagem em auxiliares de enfermagem. Também é essa a metodologia que está sendo utilizada no Programa de Profissionalização das Atendentes de Enfermagem (PROFAE) (que está sendo desenvolvido com o apoio do Ministério da Saúde com os mesmos objetivos). Esses dois programas foram levados à prática pelas próprias enfermeiras dos serviços de saúde e, portanto, há núcleos de enfermeiras que dominam essa metodologia em muitas escolas de enfermagem do país.

Foi essa também a orientação metodológica adotada no PEEPIN em Londrina, cuja implementação teve uma grande potência no desenvolvimento da percepção crítica sobre a pedagogia tradicional. Ser instrutor do PPEPIN funcionava como uma capacitação pedagógica em situação. Foi também essa a base do PIMEC, que foi o equivalente do PEEPIN em Marília.

Portanto a problematização é uma opção metodológica no campo da concepção crítico-reflexiva da educação e a aprendizagem baseada em problemas é uma opção metodológica no campo da escola nova. Essas duas concepções pedagógicas, quando adotdas em sua plenitude, levam à organização de currículos integrados e à ruptura com o ensino disciplinar, já que, nos dois casos, a organização do conteúdo se faz em função do enfrentamento de problemas. A diferença é que segundo a concepção crítico-reflexiva o problema a ser estudado tem que ser um problema real, articulado com a prática em um cenário real. Segundo a escola nova, o problema pode ser real ou pode ser construído, basta que seja desafiador ao estudante.

Ao trabalhar com problemas reais, identificados na vida real, com toda sua complexidade, a concepção crítico-reflexiva caminha mais radicalmente em direção à produção do conhecimento transdisciplinar. Particularmente na metodologia da aprendizagem baseada em problemas, os problemas são construídos pelos docentes e propiciam a articulação de saberes, mas esses saberes podem partir do 
olhar disciplinar de cada um. Ou seja, é uma metodologia que pode levar mais facilmente à produção interdisciplinar do conhecimento.

A opção, nos dois cursos de medicina estudados, pela combinação das duas concepções não foi inconsciente. Houve duras discussões, pelo menos entre os grupos mais mobilizados de docentes, não só por conta da acumulação prévia de experiência, mas porque nos cursos de enfermagem de Londrina e de Marília, que estão fazendo reformas curriculares concomitantes às da medicina, a opção foi pela problematização.

Que acontece na prática? A aprendizagem baseada em problemas aplicada radicalmente, como em Marília e Londrina, leva à adoção de um currículo integrado, em que desaparecem as disciplinas, organizado em módulos compostos por problemas etc. A análise dos problemas nos dois casos mostra que na maior parte das unidades/módulos conseguiu-se avançar na integração dos conteúdos, inclusive em relação às dimensões do processo saúde-doença. Nenhuma outra escola médica no Brasil havia conseguido destruir o currículo por disciplinas dessa maneira. Só esse fato (que está se concretizando na prática), é sem dúvida um avanço muito importante.

Resulta, nos dois casos estudados, um currículo mais moderno, flexível, em que os caminhos que o estudante vai percorrer para construir o conhecimento são individualizados (porque é o estudante que constrói seu próprio roteiro de estudo e de busca de informação) (KOMATSU, 2000). No entanto esses caminhos estão dentro de uma certa margem de previsão porque são fortemente influenciados pelos objetivos de aprendizagem de cada módulo, que orientam a construção dos problemas. A articulação entre disciplinas básicas e clínicas é extremamente favorecida por esse desenho, mas não está assegurada a articulação entre as dimensões biopsicossociais, nem a ruptura com a concepção biologista de saúde.

A proposta da problematização, a rigor, é uma ótima ferramenta para trabalhar com problemas complexos, desestruturados, os problemas da vida real (tanto os psi como os sociais). Mas implica, sempre, uma viagem ao desconhecido, 
pois não se tem controle sobre todas variáveis e ela praticamente exige uma abordagem totalizadora. Por essa razão é que a integração entre as várias dimensões (biopsicossociais) se dá quase que necessariamente.

Ou seja, se a mudança provocada pela adoção da concepção da escola nova (através da aprendizagem baseada em problemas) na prática docente é radical; a mudança de referenciais que a concepção crítico-reflexiva (através da metodologia da problematização) supõe é ainda maior . A diferença principal está na natureza do problema a partir do qual se vai buscar o conhecimento: construído, estruturado (e correndo o risco de ser biológico) ou real, desestruturado (e complexo, integral).

O fato de trabalhar sobre problemas reais, no cenário real, acarreta um certo grau de desestruturação ao processo de ensino-aprendizagem, já que os temas não estão sob controle, podem escapar do âmbito das disciplinas envolvidas e há muitos outros atores e outros interesses em jogo, por exemplo. Essa desestruturação tem sido um dos maiores desafios enfrentados pelo PIN e pela Interação Comunitária.

Uma opção metodológica e de organização dos conteúdos que estendesse essa desestruturação para todo o currículo seria quase insustentável como alternativa para os cursos de medicina nestas escolas concretas, no momento da construção da mudança. Até mesmo para a construção da proposta da Aprendizagem Baseada em Problemas foram necessárias concessões, como a do internato em Londrina e como a opção de Marília por construir suas unidades por sistemas (apesar de saber que essa organização favoreceria o reducionismo biologista).

Essa discussão traduz um dos maiores desafios que os dois currículos enfrentam: o da integração - entre suas várias partes, entre teoria e prática, entre as dimensões do processo saúde-doença. O desafio para a integração entre habilidades e módulos parece praticamente resolvido; mas falta avançar na 
integração entre habilidades e Interação/PIN e entre as dimensões do processo saúde da doença ao interior dos módulos/unidades e na prática clínica.

A experiência das Apresentações Clínicas no $4^{\circ}$ ano de Marília pode ser uma pista interessante para enfrentar esse dilema. Nessa experiência, ampliou-se o espaço da prática e desestruturou-se um pouco o formato das discussões teóricas (porque ele foi adaptado ao que os estudantes iam vendo na prática). Pela primeira vez foi de fato possível trazer a contribuição da vivência prática dos profissionais da rede básica para "dentro" do espaço de discussão teórica de estudantes e docentes. O resultado, como já vimos, foi uma maior articulação entre as dimensões biológicas, psicológicas e sociais, a inclusão de conteúdos de promoção à saúde e de prevenção às doenças.

\subsubsection{A construção do saber}

Essa é uma questão central, mas de grande complexidade, como já vimos anteriormente.

Sobre a questão da relação da medicina com a ciência, o debate não tem ocorrido explicitamente em Marília e em Londrina. No entanto, a Medicina Baseada em Evidências (MBE) e a Epidemiologia Clínica têm sido dois recursos bastante utilizados, tanto com docentes, como com estudantes, principalmente como ferramenta para busca e seleção crítica de informações. Para esse objetivo, parece-me adequada a utilização da Medicina Baseada em Evidêcias, mas vale aprofundar um pouco mais a reflexão a respeito do conteúdo dessa proposta.

A utilização das probabilidades e do cálculo de risco na epidemiologia das populações está baseada na suposição de identidade entre o possível e o provável, da homogeneidade da morbidade e de que existem regularidades e recorrências dos eventos em série em diferentes populações, numa expectativa de estabilidade dos padrões de ocorrência seriada dos fatos epidemiológicos. O risco situa-se para além dos sujeitos, localiza-se nos coletivos humanos.

Na clínica, com base na observação de séries finitas de populações, busca-se legitimar predições sobre membros individuais e singulares daquelas e de outras 
populações, com base no pressuposto de que os membros individuais manifestariam a média dos atributos de uma dada população (ALMEIDA FILHO, 2000). Mais complicado ainda, é o fato de o fator de risco ser valorizado como um sinal ou um sintoma e transformado numa entidade clínica, incorporada a um perfil patológico específico, que passa a ser diagnosticado e tratado.

Não se pode dizer, então, que a incorporação da MBE na prática clínica esteja sendo feita criticamente e há indícios de que ela possa funcionar como mais um dispositivo racionalizador, que oculta a singularidade dos indivíduos por trás das probabilidades.

Em relação à articulação das várias áreas de conhecimento, o conceito predominante nos dois processos é o da interdisciplinaridade, compreendida como a integração e articulação dos discursos disciplinares para dar conta de objetos comuns ou complexos, especialmente no processo de ensino-aprendizagem e na prática clínica. Ou seja, apesar de haver uma questão epistemológica na base da constituição do campo da saúde, o debate que ocorre em Londrina e em Marília está centrado na busca de alternativas práticas para articulação dos saberes na construção do conhecimento (ensino-aprendizagem) e na prática clínica.

O avanço mais consolidado ocorre no terreno da articulação entre as disciplinas da área biológica (básicas e clínicas), muito embora exista um importante progresso na articulação com as disciplinas das áreas psi e social.

As propostas de atenção integral ${ }^{9}$ à saúde estabelecem as bases para muitas das abordagens articuladas (no processo de ensino-aprendizagem e na organização das práticas) que existem em vários momentos nos dois cursos. Há, por exemplo, experiências interessantíssimas desenvolvidas na saúde da criança, da mulher e do idoso, campos em que a integralidade da atenção é reconhecida como fundamental e em que existem equipes multiprofissionais em ação.

\footnotetext{
${ }^{9}$ A atenção integral é entendida como uma modalidade de organização da atenção e das práticas dos profissionais de saúde capaz de levar em conta as várias dimensões e necessidades das pessoas e dos coletivos (MATTOS, 2001).
} 
Nos dois casos há também avanços particularmente interessantes na área da comunicação, que tem sido trabalhada numa perspectiva de desenvolver ferramentas que possibilitem ao profissional desenvolver a capacidade de escuta e de levar em conta a subjetividade e a especificidade das pessoas sob seu cuidado.

Especialmente em Londrina a bioética tem sido um caminho utilizado para entender e tratar de maneira mais ampla e integral as necessidades das pessoas. $\mathrm{O}$ referencial da bioética é levado em conta no processo de construção dos módulos e dos problemas e também no trabalho de desenvolvimento de habilidades de comunicação. Do ponto de vista da prática, há discussão a respeito das experiências vividas - nos PINs, nas atividades práticas das habilidades de comunicação. Há possibilidades de que isso continue acontecendo no internato, dentro do hospital, se os estudantes puderem ser envolvidos ativamente nos programas de qualidade e de humanização da atenção que vêm sendo desenvolvidos de maneira incipiente no HU.

Embora não tenha havido um debate explícito acerca dos melhores caminhos para contribuir para a formação moral dos estudantes (REGO, 2001), a opção adotada nos dois casos tem sido a da reflexão crítica sobre situações da prática, com resultados interessantes, pois existe uma percepção generalizada a respeito da postura diferenciada dos estudantes em relação aos pacientes e bastante crítica em relação aos casos de comportamento desrespeitoso que testemunham ao longo de suas experiências práticas.

Em Marília, como vimos, foi através da análise dos problemas e das unidades educacionais que se identificou a dificuldade em concretizar de modo satisfatório a proposta de articulação biopsicossocial. Inicialmente as alternativas para superar essa limitação foram buscadas através de tentativas da ampliação do referencial dos professores (inicialmente do grupo estratégico; depois, através de iniciativas da equipe de capacitação docente, o universo de docentes). Várias alternativas estão sendo exploradas: clínica ampliada, medicina psicossomática, antropologia etc. A proposta da organização de equipes de referência e apoio 
especializado matricial como base para a reorganização do hospital faziam parte desse esforço de mudanças de práticas através de buscar mecanismos que favoreçam a integralidade da atenção.

A premissa principal desse trabalho centrado na prática dos docentes é a consideração de que dificilmente se vai conseguir uma mudança qualitativa signitificativa na integração das várias dimensões do processo saúde-doença (no processo de construção das unidades, dos problemas e do raciocínio que se estimula o estudante a desenvolver) sem que haja uma transformação das concepções e da prática dos docentes.

O principal dilema que é o da integração biopsicossocial continua, portanto, impondo árduas batalhas aos dois processos. Como contribuição ao processo de construção desse novo na prática, ouso dizer ser fundamental que a incorporação dos conhecimentos vindos das outras áreas sirva para agregar potência aos atos médicos e ao processo de produção de saber sobre a saúde e a doença. De outra maneira, esses conhecimentos continuarão sendo vistos como adendos, que são acatados, com maior ou menor respeito, pelas diferentes áreas da medicina e da saúde.

Ao propor ampliar a potência da ação não pretendo "naturalizar" também estas outras esferas da vida e do ser, mas sim, colocar a questão do ponto de vista da prática... Se o processo saúde-doença é um fenômeno complexo, que não está restrito ao campo biológico, somente sendo abordado de maneira integral é que poderá se adequadamente tratado. A proposta então seria propor a configuração de equipes para ação multiprofissional, buscando maior potência. Ou seja, a proposta é abrir mão de poder disciplinar em troca de maior potência de ação.

Em relação à concepção de ser humano, trata-se de resgatar a complexidade do homem em toda as suas dimensões, muito além da biológica... Compreender que a pessoa do outro lado da linha é um ser humano complexo, que não deve abdicar de suas outras dimensões simplesmente porque adoeceu ou enfrenta alguma dificuldade em relação à sua saúde, é a outra perna fundamental para o 
reconhecimento das contribuições que outros saberes (e fazeres) têm a oferecer para as ciências da saúde (ou da doença).

Voltamos assim à questão do poder ao dizer que o homem do outro lado da mesa tem uma visão de mundo específica, desejos, necessidades e direitos, que têm que ser levados em conta para se abordar de maneira satisfatória suas necessidades de saúde e de doença. Necessidade de ser ouvido, de ser cuidado, de saber o que acontece com sua saúde, de participar das decisões, de ser sujeito, ainda quando necessite de alguma ajuda.

Neste caso, são as relações entre médico e paciente que têm que ser horizontalizadas. Se há maior capacidade de ouvir e de cuidar, pode-se construir um vínculo mais forte. Se há decisões compartilhadas, há maior chance de adesão e de sucesso. De novo, o que há para oferecer ao médico é aumento da potência da ação e da satisfação na prática clínica em troca da perda de mais uma fatia de poder.

Não se dispensa o apoio da clínica nessa construção. "Ao contrário, imagina-se que uma prática clínica renovada poderia contribuir para que os indivíduos tenham relaçôes mais produtivas com a doença, com a prevenção da saúde, com os profissionais, com os dispositivos tecnológicos e até mesmo com as instituições de saúde" (CAMPOS, 1994). Ou seja, compreender as outras dimensões e o contexto em que o paciente vive pode ajudar a construir uma proposta terapêutica mais potente, realista, comprometida, interessada em resolver, em ser efetiva.

O desafio da introdução das contribuições de outros campos no saber médico é conseguir que esses elementos sirvam para ajudar a reinventar a clínica e torná-la mais potente e satisfatória. Essa parece ser a questão central da proposta de aumentar a interface da medicina / da clínica com outros saberes e poderes no campo da prática e do ensino das profissões da saúde.

No terreno das práticas, me parece fundamental a existência do PIN e da Interação Comunitária. Em primeiro lugar, porque representa o reconhecimento de que os "problemas de papel", a base dos outros módulos, não dão conta de 
propiciar aos estudantes todas as experiências necessárias ao seu processo de formação nos primeiros anos da graduação.

Ou seja, reconhece-se a importância de haver "problemas de verdade", pois não há o que substitua o contato humano, a vivência e o compartilhar dos problemas, a solidariedade, a construção de vínculos pessoais, a apropriação da realidade, que essas experiências propiciam. Representam também o reconhecimento de que essas oportunidades têm que estar presentes ao longo de todo o curso, pois são fundamentais para a formação humanística e ética dos futuros profissionais.

Em segundo lugar porque esses módulos/unidades materializam uma mudança fundamental no processo de formação profissional e nas relações universidade-serviços-comunidade. As relações entre estudantes de diferentes carreiras, entre estudantes e profissionais dos serviços, estudantes e comunidade, os trabalhos práticos e as intervenções desenvolvidos através desses módulos são fundamentais para que se construam novas posturas e novas práticas profissionais (relação promoção/prevenção/cura mais equilibrada, maior compromisso e respeito com os parceiros e seus problemas, capacidade de comunicação, de escuta, relações mais democráticas etc.).

Constituem, também, o terreno em que se concretiza a contribuição/participação direta dos profissionais dos serviços e da comunidade no processo de formação profissional através do já mencionado compartilhar de objetivos e ações. Esse é o espaço para que as necessidades sociais, identificadas e apresentadas pelos sujeitos sociais, sejam tomadas como objeto dentro do processo de formação.

Ou seja, o fato de haver oportunidades significativas para que os estudantes trabalhem sobre problemas reais abre espaço para que seja superada uma possível limitação da proposta metodológica adotada (o fato de que a aprendizagem baseada em problemas admite a possibilidade de trabalhar somente com problemas construídos, que reduzem a complexidade da realidade). Portanto, a 
existência desses módulos parece ser fundamental para que uma parte dos objetivos da transformação do processo de formação se concretize.

Uma grande dificuldade enfrentada na concretização dessas unidades/módulos, como já comentado, tem sido a "desestruturação do mundo real", que acaba sendo introduzida dentro do processo de ensino-aprendizagem e que é reconhecida como "falta de clareza acerca dos objetivos" ou associada "aos problemas existentes na realidade da rede de serviços de saúde".

As dificuldades metodológicas acontecem quando é necessário enfrentar problemas complexos, geralmente trazidos pela população, que fogem do "âmbito normal" de ação dos profissionais de saúde. Por outro, a busca pela integralidade esbarra na fragmentação do trabalho das unidades básicas de saúde, que dificulta a inserção dos estudantes, restringindo sua ação à introdução de ações de promoção e prevenção e de educação em saúde.

Em Marília e em Londrina existe uma clara percepção em relação às limitações da clínica tradicional na articulação de campos de saberes e dimensões do processo saúde-doença, mas em nenhum dos dois casos existe uma reflexão crítica a respeito das dificuldades que também a epidemiologia enfrenta nesse terreno.

Nas duas experiências analisadas a articulação do trabalho de docentes e estudantes com as unidades de saúde da família resultou mais satisfatória, produtiva e prazeirosa, provavelmente porque a saúde da família é estruturante e é integradora dos campos da ação sobre os coletivos e das ações individuais (PINHEIRO, 2001).

Se a melhor maneira de refletir é pensar sobre a prática e retornar a ela para transformá-la, essa multiplicidade de experiências constitui-se em uma excelente oportunidade para a produção dialética de conhecimentos que ajudam a romper as limitações das práticas instituídas, para além das vontades e dos discursos ideológicos. 


\subsubsection{As mudanças nas relações}

As mudanças nas relações foram muitas, importantes e de todos os tipos, mas sempre no sentido da democratização, da horizontalização, da abertura de novos espaços para a participação ativa dos sujeitos.

O principal destaque fica para a transformação das relações entre professores e estudantes e para a mudança dos papéis de cada um deles dentro do processo de ensino-aprendizagem.

Os estudantes de fato se tornaram sujeitos do processo de ensinoaprendizagem, conquistaram autonomia, iniciativa, capacidade de crítica e de proposição. Muitos dos professores redescobriram o prazer a possibilidade de estabelecer vínculos no processo de ensino-aprendizagem; ficam encantados com os espaços da interdisciplinaridade, desafiados com a necessidade de mudar conceitos e práticas para poder dar conta dos novos problemas e insuficiências que vão percebendo pelo caminho.

Foram mudadas as normas acadêmicas e o reconhecimento do que é o trabalho docente; as disciplinas e os departamentos perderam autonomia na definição de conteúdos e metodologias: houve, de fato, uma redistribuição de poder e o estabelecimento de novos acordos e compromissos.

Revelaram-se como essenciais nesse processo de mudança os espaços de discussão e a possibilidade de reflexão crítica sistemática, pois encarar de frente os problemas, assumir de fato a postura de construção e reconstrução permanente das propostas de ensino-aprendizagem é a melhor maneira de fortalecer o processo. Falta de conversa, de reflexão crítica e de desafios levam à estagnação e ao risco de retrocesso.

A parceria entre universidade, serviços e comunidades trouxe a oportunidade de democratizar relações, mas principalmente na esfera da política, no espaço da ação cidadã. Isso é fundamental, mas não suficiente, pois essa 
democratização não se transfere automaticamente para os outros espaços da prática e das relações.

Em Londrina, a comunidade organizada fala, identifica problemas, aponta soluções, compartilha o trabalho das ações coletivas em saúde. Mas houve pouca inovação, pouco avanço no terreno da autonomia dentro da relação médicopaciente na esfera da clínica. Em Marília falta a voz da comunidade, sujeito essencial, que não pode ser inventado. Nos dois casos é um trabalho por fazer, claramente articulado ao desafio da reorganização do modelo de atenção à saúde no país no sentido da integralidade.

A constituição de sujeitos foi a marca fundamental desses processos e, como vimos, foi fundamental para propiciar e impulsionar as mudanças

\subsection{Os projetos UNI e as outras estratégias de mudança}

Como já comentado, os projetos UNI em geral e particularmente os brasileiros interagiram ativamente com as outras estratégias de mudança vigentes na última década. Essa interação inicialmente foi estimulada pelo programa de apoio aos projetos UNI, que propiciou a participação de representantes dos projetos em seminários viajeiros, congressos e reuniões internacionais; estabeleceu as bases iniciais para a cooperação técnica entre alguns centros internacionais e os projetos UNI (com Dundee, com a Network, com a Universidade de Chicago por exemplo).

A interação com a proposta da OMS serviu para colocar de maneira mais clara a questão da relevância social e resultou, para Londrina, em sua designação como Centro Colaborador. No entanto, essa designação não implicou, até o momento, atividades ou aportes específicos de qualquer natureza para o fortalecimento de seus processos internos de mudança.

A interação com a Network resultou em benefícios importantes especialmente para uma compreensão mais clara e profunda acerca da mudança 
pedagógica: foi essa a porta de entrada da aprendizagem baseada em problemas nos dois projetos. No entanto, cabe destacar que essa interação se deu principalmente através da contratação de assessoria técnica (particulamente de Maastricht) e não como conseqüência da participação dos projetos no movimento da Network. Outras assessorias técnicas cumpriram também papel semelhante (McMaster, Chicago, Dundee - esta última com menor peso).

A participação nos congressos e reuniões da Network serviu sobretudo para começar a construir uma visibilidade internacional para os projetos UNI e para que os atores dos projetos tivessem uma apreciação mais clara acerca das diferenças de contexto e do que estava acontecendo de interessante e inovador no resto do mundo. Ou seja, a Network, como movimento, não influiu sobre os projetos, nem no Brasil, nem na América Latina.

Cabe destacar que todas essas outras estratégias de mudança da formação dos profissionais de saúde trabalham de maneira distinta a construção de alianças (em relação à proposta desenvolvida pelos UNI).

A Network, até recentemente, não se preocupava em influir em outros espaços que não os das próprias escolas e o de sua articulação em rede. Desde o ano 2000, entretanto, essa preocupação passou a fazer parte de seu repertório político e o referencial adotado foi o mesmo da proposta da OMS.

O "Towards Unity for Health", a proposta da OMS, identifica, como atores centrais para a mudança da educação médica, as instituições de ensino, as instituições de serviço e as entidades profissionais médicas.

A proposta da CINAEM, apesar de basear-se, em parte, em um referencial estratégico, procura mobilizar, como atores da mudança no espaço local, os estudantes e professores e, como participantes da construção conceitual da proposta, as entidades profissionais médicas.

Ou seja, há uma mescla de alianças com atores mais favoráveis e menos favoráveis às mudanças. No caso da CINAEM, a ausência dos serviços (gestores e profissionais) e da comunidade como aliados restringe, na prática, os referenciais e 
o cenário em que se pretende construir a mudança. Perde-se a oportunidade de construir uma aliança estratégica com grande potencial de resultados positivos e, ao mesmo tempo, reforçam-se os vínculos e compromissos das escolas com as entidades da corporação médica.

No momento atual essa aliança preferencial é bastante complicada, já que a categoria médica encontra-se profundamente pressionada. Suas entidades têm apresentado a tendência de defender radicalmente a manutenção do status quo, opondo-se à saúde da família e à diminuição da importância dos especialistas dentro da organização da atenção.

No entanto, em todos esses anos de vigência dos UNI, o único outro movimento real para mudança na formação médica existente no Brasil, ao lado do conformado pela Rede UNIDA, foi o da CINAEM. No capítulo 3 foram apresentadas as bases conceituais e as estratégias teóricas previstas pelas duas propostas e a participação dos UNI no movimento da CINAEM.

Vale a pena, ainda, analisar brevemente quais foram as outras estratégias desenvolvidas na prática pela CINAEM e pelo UNI e discutir um pouco as diferenças de condução e de resultados.

A próxima figura ilustra os conceitos e instrumentos adotados nas propostas de mudança implantadas em Londrina e em Marília, bem como os que estão presentes nas definições conceituais produzidas pela CINAEM em sua terceira fase: 
Figura 50. Principais conceitos e instrumentos metodológicos das propostas UNI e CINAEM na prática.

\begin{tabular}{|c|c|c|}
\hline CONGEITO (c) OU INSTRUMENTO METODOLOGICO (im) & UNI & CINAEM \\
\hline Articulaģāo biologicosocial (c) & $+t$ & + \\
\hline Avaliaģāo como instru mento de mudança (im) & $+t$ & $+t$ \\
\hline Capac itaçāo pedagogica (im) & $+t$ & - \\
\hline Desenvolvimento de lideranga (im) & $+t+$ & + \\
\hline $\begin{array}{l}\text { Desesenvolvimento Integrado de modelosacademicos e de } \\
\text { mode los de atençāo (im) }\end{array}$ & +++ & - \\
\hline Educaçāo centrada no estudente (c) & $+t+$ & - \\
\hline Educaģāo orie ntada a comunidade (c) & ++ & + \\
\hline Gestāo estrategica (im) & $+t+$ & ++ \\
\hline Interdisc iplinaridade (c) & +++ & ++ \\
\hline Intersetorialidade (c) & ++ & $+t$ \\
\hline $\begin{array}{l}\text { Metodologias ativas de ensino-aprendizagem incluindo ABP } \\
\text { (im) }\end{array}$ & +++ & + \\
\hline Multiprofissionalidade (c) & $+t+$ & - \\
\hline Investigaçāo como instrumen to de mudança (im) & + & - \\
\hline Planejamento estratégico (im) & ++ & + \\
\hline $\begin{array}{l}\text { Relaçōes entre prática, ed ucaçäo de prolissionais de saúde } \\
\text { e estrutura social (c) }\end{array}$ & ++ & ++ \\
\hline $\begin{array}{l}\text { Responsabilidade social da escola (equidade, qualidade, } \\
\text { relevancia, custo efetividade)(c) }\end{array}$ & ++ & ++ \\
\hline
\end{tabular}

(-) nenhuma importáncia; (+) pouca importáncia; (+t) importáncia razóavel; (+++)

muita importancis

A próxima figura ilustra as estratégias que foram implementadas na prática pelas duas propostas: 
Figura 51. Principais estratégias de mudança na prática das propostas UNI e CINAEM.

\begin{tabular}{|c|c|c|}
\hline $\begin{array}{l}\text { Principais estratégias de mudança } \\
\text { na prática }\end{array}$ & UNI & CINAEM \\
\hline Abordagem multiprofissional & + & - \\
\hline $\begin{array}{l}\text { Aprendizagem basada em problemas } \\
\text { (ABP/PBL) }\end{array}$ & + & - \\
\hline Auto-a valiação como estratégia de mudança & + & + \\
\hline $\begin{array}{l}\text { Sustentabilid ade progressiva e } \\
\text { in stitucionalização dos process os }\end{array}$ & $H$ & - \\
\hline Comunicação e dis seminação & + & - \\
\hline Educação permanente & + & + \\
\hline Parceria professoreslalunos/ comunidade & + & - \\
\hline $\begin{array}{l}\text { Parceria universidad e/s erviços de } \\
\text { saúdelcomunidade }\end{array}$ & +4 & - \\
\hline $\begin{array}{l}\text { Parceria universidadelserviços de } \\
\text { saúdelentidades médicas }\end{array}$ & - & + \\
\hline Pesquisa-ação colaborativa & - & - \\
\hline Proatividade dos proponentes & + & + \\
\hline $\begin{array}{l}\text { Programa de apolo permanente às } \\
\text { iniciativas de mudança }\end{array}$ & + & - \\
\hline Trabalho em rede & + & - \\
\hline
\end{tabular}

Os UNI, como se vê, enriqueceram o arsenal conceitual e de estratégias em sua prática concreta, superando várias limitações da proposta inicial do programa. Já na prática da CINAEM houve um empobrecimento do referencial conceitual, que se traduz em uma importante escassez de estratégias.

Aparentemente considera-se a avaliação como estratégia suficiente para produzir mobilização e levar à mudança nas escolas. É verdade que na primeira e na segunda fases a CINAEM conseguiu, com a proposta de avaliação, ampliar de modo significativo a mobilização das escolas em relação à discussão da educação médica no país. Vale ressaltar também que o consenso das entidades da corporação em torno da proposta de avaliação aumentou sua aceitação nas escolas.

A avaliação, como vimos, é uma das estratégias que pode ser utilizada para promover a reflexão crítica sobre as práticas tradicionais (docentes, de investigação e de atenção clínica). Na verdade ela é necessária, útil como estratégia de mudança, 
mas não é absolutamente suficiente. Como vimos, são necessárias outras estratégias, é preciso mobilizar os professores, investir em capacitação docente, estimular o desenvolvimento de alternativas inovadoras, ampliar as alianças (dentro e fora das escolas), conquistar espaços de poder. Um mundo de coisas que nunca entrou na agenda da CINAEM...

Além disso, no movimento da CINAEM considerou-se, na prática, que o "locus" principal da construção das propostas de mudança para as escolas eram os espaços nacionais de reunião (fóruns e as oficinas de trabalho). Daí também decorre a idéia de que é possível controlar centralmente um movimento de mudanças e determinar datas, prazos, caminhos a serem cumpridos pelas escolas.

No entanto isso não é possível, nem desejável, já que as mudanças se constróem no espaço local, a partir das condições específicas de cada escola. $\mathrm{O}$ espaço coletivo nacional serve para discutir problemas, compartilhar estratégias, construir princípios, mas não pode substituir o local e seus sujeitos concretos...

Existiu também sempre um suposto de que as atividades realizadas nas oficinas nacionais se refletiriam automaticamente nas escolas. No entanto, desde a segunda fase da CINAEM, isso não vem ocorrendo, já que quase nenhuma escola constituiu equipes gestoras realmente funcionantes e em poucas escolas as discussões ocorridas nos fóruns foram ampliadas para o conjunto ou ao menos para um número significativo de professores. Um exemplo claro disso foram as oficinas de planejamento estratégico: apesar de realizadas em várias regiões do país, não levaram a uma apropriação da metodologia, tanto que essa ferramenta não foi usada para construir processos locais de mobilização em outras escolas que não as UNI.

Os professores e estudantes que participam das reuniões da CINAEM precisariam ter estratégias para ampliar a discussão e a mobilização de acordo com a realidade específica de suas escolas, mas como foi sempre a lógica desse "coletivo nacional" que predominou, não houve espaço para discutir o que estava acontecendo no mundo real (ou seja, nas escolas e nos contextos locais das relações 
com os serviços e com as comunidades). Como resultado, houve um distanciamento desse "grupo mais avançado", que participava das formulações, em relação ao conjunto de professores das escolas (que deveria acatar essas formulações).

Um outro problema importante foi a compreensão equivocada que predominou na CINAEM acerca do contexto político nacional em relação à educação e às possibilidades de aproveitar oportunidades para fazer avançar os movimentos de mudança.

Quando o MEC iniciou a implantação de sua proposta de avaliação das instituições de ensino superior através do Provão e das Condições de Oferta, a CINAEM se opôs a essa metodologia de avaliação e colocou-se como alternativa metodológica para Avaliação Nacional dos Cursos. Perfeito, já que a proposta metodológica construída na segunda fase leva em conta outros aspectos que não somente a avaliação cognitiva dos estudantes. No entanto, para poder constituir-se de fato nessa alternativa, a CINAEM nunca poderia haver insistido na decisão de manter sigilososo o resultado da avaliação (propunham que ele fosse somente de conhecimento das escolas). Ora, o principal mérito do Provão é justamente tornar públicos os resultados da avaliação - direito inegável da opinião pública e instrumento indispensável de pressão sobre as escolas no sentido da mudança. Se os resultados da avaliação da CINAEM não podiam ser públicos, ela não podia ser uma alternativa ao Provão...

A postura de rejeição a toda e qualquer iniciativa que partisse do governo federal fez também com que a CINAEM entrasse muito tardiamente (somente nos momentos finais) no processo de discussão a respeito das diretrizes curriculares de medicina.

Tudo isso foi levando a um isolamento e a um esvaziamento do movimento, impossibilitando o início da quarta fase, já que nenhuma escola apresentou sua adesão ao projeto. É verdade que a proposta mantém grande força 
entre os estudantes, mas o problema é que não é possível mudar a escola médica a partir somente dos estudantes....

Vale a pena também fazer alguns comentários acerca da proposta de organização curricular apresentada por SANTOS (2001), já que ela contém muitas imprecisões conceituais e uma compreensão limitada acerca de como se pode construir a mudanças nas escolas.

Não será destinando à abordagem do psi e do social os dois primeiros semestres do curso que se vai avançar em direção a uma abordagem integral do processo saúde-doença. A integração, como vimos, tem que ser perseguida em todos os momentos e em todas as atividades; ela não acontece automaticamente tem que ser construída, preparada, trabalhada. Então, a proposta apresentada reproduz as dicotomias atualmente existentes, só que com nova roupagem e, na prática, reserva muito pouco tempo para a incorporação dessas abordagens.

Outro exemplo, a simples observação da demanda espontânea dos serviços não leva à identificação das necessidades de saúde, pois para tanto é necessário que existam espaços de escuta e acolhimento às demandas da população, que não se constituem espontaneamente nos serviços de saúde - têm que ser construídos.

Aliás, como os profissionais dos serviços e a população não são atores contemplados pela CINAEM na construção das propostas de mudança dentro das escolas (e, a rigor, nem no espaço nacional), na prática os serviços de saúde são encarados como cenários físicos, em que os docentes e os estudantes realizam suas práticas sem levar em conta necessidades, projetos, interação ou contrapartida com os outros atores que também "freqüentam" esses espaços. De outro modo, como seria possivel construir de maneira unilateral todas essas proposições?

As complexas questões metodológicas envolvidas na mudança das escolas são tratadas como problemas resolvidos, cujas soluções estariam nos conjuntos "de instrumentos e tecnologias" que são mencionados de passagem. O mesmo acontece com os temas da intersetorialidade e da transdisciplinaridade. 
Ou seja, há uma subestimação da complexidade dos processos e dos conteúdos envolvidos na necessária mudança da educação médica, que dificulta fazer avançar o processo.

\subsection{Uma reflexão sobre o UNI em outros contextos nacionais}

Com base na análise dos projetos no Brasil e nos outros paíse, é possível identificar elementos críticos para o desenvolvimento dos UNI e para o desenvolvimento de movimentos de mudança na formação dos profissionais de saúde em geral.

Em primeiro lugar estão o contexto político e a orientação da reforma setorial em cada país. Como já discutido, a idéia-chave do UNI é construir a mudança em um "cenário ampliado", que envolve a articulação com outros atores, externos à universidade, com o objetivo de fortalecer "o lado" da mudança

Quando o UNI se iniciou, a maior parte das reformas setorias em saúde na América Latina tinha como orientação a universalidade, a eqüidade e a descentralização através do desenvolvimento de sistemas locais de saúde diretrizes com as quais se identificava o ideário do Programa. No entanto, a partir da primeira metade dos anos 90 houve uma reorientação da maior parte das reformas no sentido da focalização, da diminuição do papel do Estado e do desfinanciamento do setor.

Em função dessa mudança da orientação, em muitos casos os UNI se converteram em "peça de resistência" à exclusão e à mercantilização da saúde (o que foi positivo). No entanto, criaram-se situações em que deixou de haver interesse político ou pressão por parte dos serviços no sentido das mudanças na formação profissional e, em conseqüência, a estratégia da parceria perdeu potência transformadora.

Mas a capacidade de cumprir esse papel de resistência articulada depende também do contexto politico, do nível de amadurecimento das relações democráticas, da história prévia de organização popular e de relações de 
cooperação política entre universidade, serviços e população. México, Chile e Peru, apesar de suas diferenças, somente em anos mais recentes entraram em um processo efetivo de democratização. Colômbia é um país conflagrado, com seu tecido social esgarçado e instituições incapazes de garantir a paz. Independentemente da situação econômica, mas em função da história política mais recente, em nenhum desses contextos o direito à saúde está colocado nos mesmos termos que no Brasil - acesso universal, equitativo, gratuito, garantido pelo Estado.

Não é por acaso, portanto, que os resultados de maior impacto dos UNI estão sendo obtidos no Brasil, principalmente em função da orientação e do processo de construção da Reforma Sanitária - que foi democrático, envolveu articulação de múltiplos setores e a construção de um movimento em defesa do direito à saúde, apesar de todas as dificuldades e contradições enfrentadas.

Outro elemento crítico para o desenvolvimento dos UNI - e de movimentos de mudança na formação profissional - é a capacidade de articulação mais ampla para influir nas políticas públicas. Como discutido, o contexto e a orientação das políticas são condicionantes importantes dos movimentos de mudança na formação dos profissionais de saúde.

Ser capaz de influir nas políticas, contribuindo para a existência de contextos e de políticas mais favoráveis, é um elemento central para a construção de viabilidade e sustentabilidade das mudanças. A estratégia mais potente para conseguir esse objetivo é a articulação em Rede - como caminho para a constituição de um ator politico, um sujeito coletivo, mais poderoso que cada projeto ou grupos de projetos UNI isoladamente, e capaz de intervir em outras esferas.

Outra vez foi no Brasil que a estratégia funcionou melhor, através da Rede UNIDA, que tem papel ativo no fortalecimento dos movimentos de mudança e na influência en políticas. Nos demais países houve capacidade para influir em políticas locais e também para ser reconhecido como referência em alguns campos 
de ação.

Do ponto de vista da construção da ação estratégica, um dos elementos cruciais para produzir mudanças no processo de formação dos médicos é a capacidade de construir massa crítica e de conquistar espaços de poder dentro da academia. Processos profundos de mudança pressupõem a constituição de sujeitos e, portanto, têm que ser participativos e construídos com base na reflexão crítica sobre as práticas - tanto na academia como nos serviços. Esse é um processo que se constrói de maneira deliberada, tendo em conta as diferentes identidades profissionais. Os projetos que conseguiram construir massa crítica puderam avançar mais; os que não foram capazes de fazê-lo avançaram menos.

Além disso, processos profundos de mudança implicam redistribuição de poder e enfrentam resistências; trabalhar estrategicamente, acumulando poder a favor e diminuindo resistências foi fundamental para conseguir avançar.

De qualquer modo, apesar das diferenças de contexto e dos processos desencadeados, a experiência de buscar construir mudanças na formação dos profissionais de saúde com base em uma aliança estratégica entre sujeitos sociais da universidade, dos serviços e da população provocou resultados. Inovações em muitos casos, mudanças em outros aspectos, certamente a constituição de sujeitos sociais que, pouco a pouco, estão se colocando ativamente nos cenários politicos de seus países. 


\section{Considerações finais}

\subsection{Uma síntese provisória}

Os dois casos analisados revelam a complexidade do desafio imposto pela mudança do processo de produção dos médicos. As escolas médicas são instituições complexas, que articulam uma multiplicidade de sujeitos, de identidades e de interesses. Transformar o processo de formação implica mudanças na concepção de saúde, na construção do saber, nas práticas clínicas, nas relações entre médicos e população, entre médicos e demais profissionais da saúde, na concepção de educação e de produção do conhecimento, nas práticas docentes, nas relações entre professores e estudantes, nas relações de poder entre dos departamentos e disciplinas.

São, portanto, mudanças profundas que implicam a transformação não somente de concepções e práticas, mas também de relações de poder dentro das universidades, dos serviços de saúde e do território local e também no espaço social, no campo das políticas.

A universidade não vai adquirir compromisso e relevância social sem se abrir para o mundo do trabalho e para o mundo da vida; os serviços não vão se transformar no sentido desejado se não se abrirem para a população, para seus interesses e objetivos concretos.

A base das propostas de mudança em questão é a democratização, um produto social que se constrói através da intervenção deliberada de sujeitos e que depende da correlação de forças, da mudança dos poderes instituídos, da capacidade de se construírem espaços de poder compartilhado.

A mudança institucional, portanto, começa já no próprio processo de construção da proposta de transformação, que deve ser feita através da criação de espaços coletivos, possibilitando a participação do maior número possível de professores e alunos, do maior número possível de áreas e departamentos. 
Estudantes, professores, profissionais de saúde e usuários têm que ser sujeitos desse processo de mudança. Esses sujeitos se constituem no processo coletivo de reflexão crítica sobre as práticas tradicionais, de aquisição de novos conhecimentos e de novos poderes que diminuam as distâncias entre dirigentes e dirigidos.

Por essa mesma razão, as transformações não são definições a priori. Elas se constroem no cotidiano da prática pedagógica e não simplesmente no papel; na prática clínica concreta e não somente "em laboratório" ou "ambientes especiais", em todos os cenários onde se dá a prática profissional e enfrentando os problemas que se apresentam na realidade.

A condução de um processo de mudança como esses não pode ser ingênua: tem que levar em conta a necessidade de ativamente acumular poder a favor e diminuir a capacidade de ação das forças contrárias. Processos de mudança não são estáticos, ao contrário. Quem está de um lado hoje pode estar do outro amanhã. Planejamento estratégico combinado com um esforço organizado de construir canais de comunicação e discussão coletiva são alguns dos instrumentos essenciais para a condução e a construção dos processos de mudança.

Os projetos UNI de Londrina e de Marília constituem-se em contribuições efetivas para a compreensão desse processo de transformação. Nos dois casos, há grupos articulados, buscando agir estrategicamente, com graus distintos de acumulação de poder e de capacidade de reflexão crítica. São dois programas de ação estratégica.

Foram significativas as contribuições da proposta UNI para o desenvolvimento desses processos de mudança e muito importante também a capacidade - dos projetos e do programa de apoio - de perceber suas limitações e de buscar outros referenciais e instrumentos que possibilitassem melhor compreensão do problema e, conseqüentemente, subsidiassem melhores propostas de ação. 
A percepção de que a sustentabilidade e a profundidade das mudanças que estavam sendo construídas no espaço local dependia de mudanças no espaço das políticas foi também fundamental. E a alternativa encontrada - a articulação em rede - é estratégica e adequada a um "jeito mutante" de fazer política, pois possibilita articulação flexível, participação variável, unidade em torno de questões concretas: são heterogeneidades organizadas, que ganham potência de ação ao se associarem.

É muito, muito clara a importância do contexto, das mudanças na organização e no conteúdo das práticas de saúde, assim como a participação de sujeitos sociais da saúde na mudança do processo de produção de médicos: a transformação do modelo de atenção e da formação profissional estão acontecendo de maneira articulada, imbricada - uma potencializa a outra e uma não acontece sem a outra.

Os processos de mudança de Londrina e Marília estão situados entre o segundo e o terceiro plano de profundidade das mudanças. Situação que é dinâmica, como já exaustivamente comentado. Ou seja, no momento atual os dois processos caracterizam-se como reformas e contêm elementos de transformação em função das transformações de algumas relações, do trabalho sobre as necessidades sociais de saúde e da busca por práticas transformadoras no campo da educação e da saúde.

Essa caracterização pode ser revertida a depender dos processos de consolidação que estão sendo inaugurados nos dois casos. Há níveis diferentes de acumulação, mas os dois processos necessitam de uma fase de consolidação. No entanto, os dois processos demonstram importante vitalidade, sujeitos sociais constituídos e capacidade de articulação.

\subsection{Um pouco mais de debate teórico-conceitual}

Escolas médicas, como vimos, são instituições complexas, articuladas em dois espaços setoriais, quais sejam a saúde e a educação, o que implica a existência de 
uma diversidade de inserções no trabalho e, portanto, de identidades grupais em seu interior. Produzir médicos é uma das atividades importantes realizadas dentro da escola médica, mas também o são a prestação de serviços de saúde e a produção de conhecimento.

Apesar de ser uma instituição de ensino, subordinada a regras e definições do campo da educação ${ }^{10}$, pode-se dizer que, historicamente, é através do setor saúde que se definem suas mais fortes conexões com o espaço social global, particularmente através da prática médica.

Afinal, a principal reforma do ensino médico no mundo ocidental no século XX, desencadeada através do Relatório Flexner, foi proposta tendo em vista a necessidade de reorganizar e ordenar a prática médica. Ou seja, um mesmo relatório estabeleceu as bases de uma nova medicina, de uma nova prática médica e de uma nova maneira de produzir médicos.

Retomemos a proposta de ALMEIDA (1999) para análise do plano de profundidade das mudanças no processo de produzir médicos. A Figura 52 ilustra o esquema geral dessa proposta.

${ }^{10}$ Por exemplo, a grande expansão das escolas médicas no país a partir de 1965 "refletiu tanto a pressão das classes médias urbanas por aumento de vagas no sistema universitário, como também satisfez as expectativas dos planejadores, que buscavam atender às novas necessidades do desenvolvimento da assistência médica no país"(MACHADO, 1997). 
Figura 52. Planos de profundidade das mudanças no processo de produção de médicos

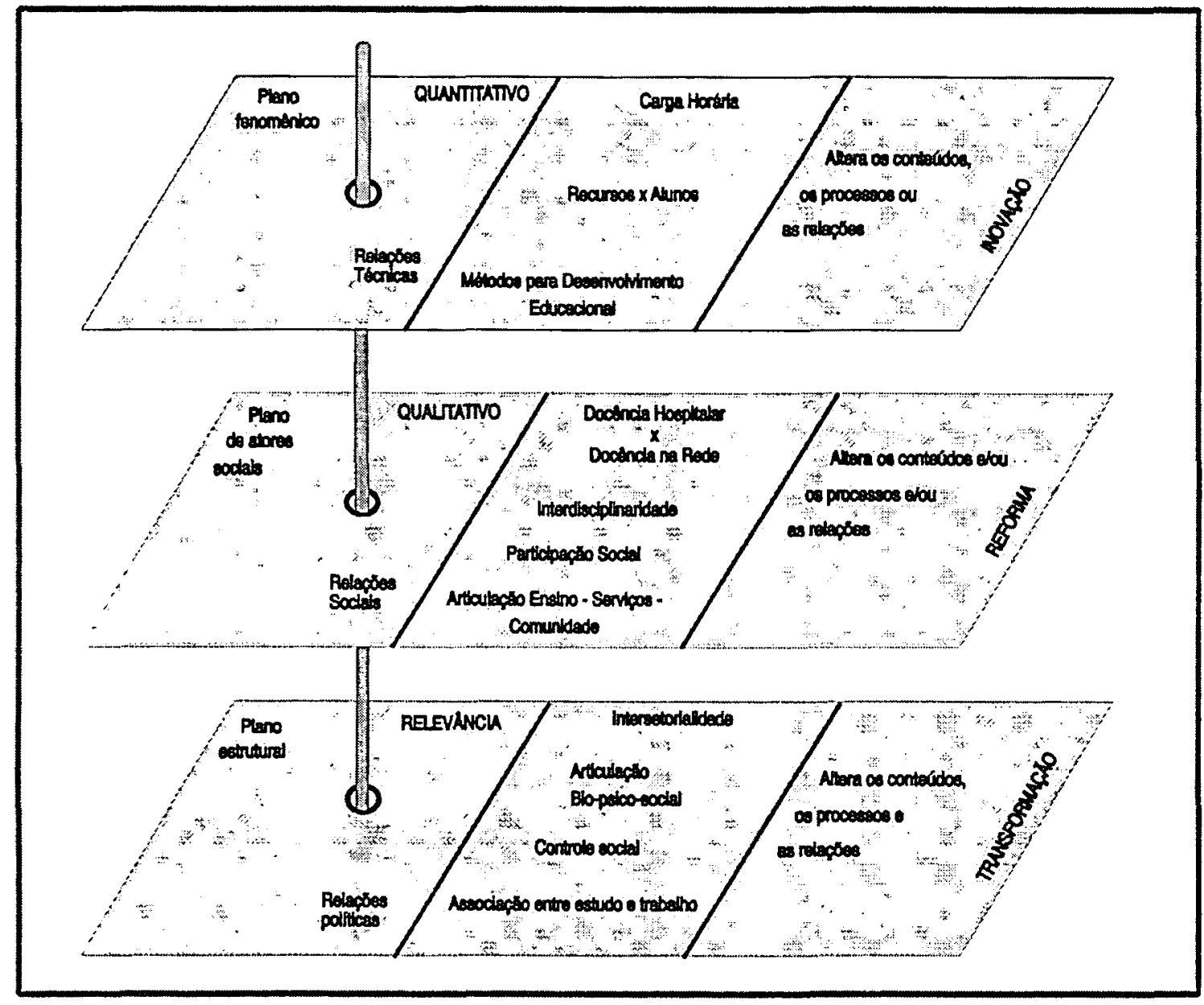

Fonte: ALMEIDA (1999)

Parece-me que os planos, além de revelar a profundidade das mudanças, implicam também a utilização de referenciais teórico-conceituais diferentes para a construção de conceitos e de práticas em educação e em saúde.

O primeiro plano corresponde à concepção tradicional de educação e à concepção biologista em saúde. Predominam os sujeitos ideológicos e as práticas hegemônicas, tanto em saúde como em educação, são reproduzidas. Inovações são possiveis, mas pontuais.

O segundo plano corresponde à concepção humanista (libertária) de educação e ao conceito ampliado de saúde. Através de práticas de reflexão crítica, há a constituição de sujeitos e a busca de alternativas às práticas hegemônicas. Há 
democratização de relações. Nos dois casos (educação e saúde) o social é reconhecido, estudado, levado em conta, mas os sujeitos sociais do espaço social não estão incorporados como sujeitos nem no processo de educação e produção de conhecimento, nem no espaço da saúde.

O terceiro plano corresponde à concepção pedagógica crítico-reflexiva e ao pensamento estratégico em saúde. Constituição de sujeitos, busca de práticas transformadoras e a incorporação dos sujeitos sociais ao processo de educação e de saúde: são as necessidades de saúde (identificadas pelos sujeitos sociais) que são o ponto de partida para a busca do conhecimento e para a organização da atenção à saúde.

Os exemplos práticos incluídos no modelo apresentado por Almeida, no entanto, são "datados" (FERREIRA, 1988), ou seja, é importante compreender que a tradução do significado qualitativo das mudanças para o terreno da prática muda de acordo com a construção social desse conceitos.

Gostaria de propor duas alterações na caracterização dos planos propostos por ALMEIDA (1999). Uma em relação ao segundo plano, que ficaria caracterizado como o dos atores sociais e das relações de força. Corresponde ao processo da constituição de sujeitos. Através da construção de espaços coletivos de reflexão, da democratização do conhecimento, da percepção de que os sujeitos têm possibilidade de ação real (quer dizer, a percepção de que há espaço e recursos de poder para levar proposta à prática). Aqui as mudanças incidem em dimensões mais abrangentes do processo de formação profissional, da prestação de serviços e da participação popular, quais sejam as relações sociais, estabelecendo novos critérios de convivência entre os sujeitos envolvidos.

Outra diz respeito ao terceiro plano. Os requisitos apresentados para que uma mudança possa ocorrer no terceiro plano implicam, como diz o autor, uma transformação que vai além da escola médica. Ou seja, só seria possível transformar a escola médica num processo de superação do capitalismo, de mudança radical da lógica econômica e social - como foi o caso de Cuba. 
Claro está que a viabilidade de qualquer mudança, especialmente as profundas, tem que ser construída. No entanto, não me parece que somente os processos de transformação estrutural sejam capazes de gerar uma situação conjuntural favorável a mudanças profundas. Podemos mencionar como exemplos, a reforma do sistema de saúde inglês, que foi feita imediatamente no pós-guerra (TESTA, 1995) e o modelo de formação médica, adotado no Reino Unido, baseado no relatório Dawson e não na orientação flexneriana.

Ou seja, há possibilidades de adotar outro referencial e outros valores e não submeter a organização do sistema de saúde e da educação médica à lógica do capital mesmo na vigência do capitalismo. Estamos falando de condicionamentos estruturais, que admitem a construção de variantes sob a ação dos sujeitos e a especificidade dos contextos e das relações de força em dado momento histórico.

TESTA (1995) ao discutir as estratégias para a construção de processos de mudança propõe a estratégia de programas articulados: programas de abertura (que servem para mobilizar grupos e construir viabilidade para uma mudança), programas de avanço (que correspondem à realização efetiva da mudança) e programas de consolidação (que têm o objetivo de ativamente reforçar os avanços, já que os processos são dinâmicos, os avanços não são lineares e sempre há risco de retrocessos).

Diz também que processos de mudança construídos em situações de acumulação de recursos de poder "podem aproximar-se de uma transformação, que pode ser limitada, mas que funda a nova linha de base a partir de qual se vão redefinir as discussões (as contradições) e os conflitos (as lutas) da história futura" (TESTA, 1995).

Processos de democráticos de mudança social são construídos através de estratégias de acumulação de recursos de poder, de conquista de espaços ao longo do tempo, mesmo na hipótese de um momento de tomada radical do poder. Antes e depois desse momento continuam a existir conflitos, interesses distintos e disputas de poder (ainda que sob outra hegemonia), que se expressam de maneira mais ou menos explícita de acordo com a correlação de forças e o nível de 
democracia existente. Não existiria, portanto, uma transformação automática da escola médica, determinada pelas novas relações estruturais: haveria, sim, uma conjuntura mais favorável para que as transformações acontecessem.

Além disso, desde a queda do muro de Berlim e do fim do socialismo real, as perspectivas de uma transformação social radical no sentido sugerido por ALMEIDA mudaram substancialmente. Com a exceção de regimes que tendem ao isolamento total (como o do Taleban no Afeganistão), são pequenas as chances de rupturas radicais com o modelo do capitalismo globalizado e não está clara qual será a direção da transformação das bases da economia mundial.

Apesar do contexto internacional difícil e da perplexidade das esquerdas e dos movimentos sociais diante desse cenário, a perspectiva de construção da utopia continua existindo.

Trata-se, como diz Boaventura Santos, de buscar construir "as emancipações" - formulação plural porque "essa transformação assume características diferentes, requer diferentes coligações progressistas e está sujeita a diferentes ritmos nos diferentes espaços estruturais". Em todos os casos "a transformação resultaria da substituição gradual da dinâmica de desenvolvimento dominante pela dinâmica de desenvolvimento emergente e, portanto pela contradição e competição paradigmáticas" entre distintos grupos e coligações. Em todos os espaços o paradigma emergente se construiria a si mesmo através da "transformação do poder em autoridade compartilhada, do direito despótico em direito democrático e do conhecimento-regulação em conhecimento-emancipação" (SANTOS, 2000).

Proponho, então, relativizar as exigências do terceiro plano, pois, mesmo sem a mudança radical de todas as relações sociais, hipoteticamente seriam possíveis acumulações setoriais que viabilizassem transformações ao interior de escolas. Mais forte ainda essa possibilidade considerando que existe uma acumulação de elementos de crises e rupturas no campo da filosofia e das ciências, questionamentos substantivos à ordem racionalista e à sua influência na conformação dos saberes e das práticas. 
Ou seja, estamos em um daqueles momentos históricos em que surgem muitas perguntas e questionamentos, em que há busca significativa por alternativas, em que muitas contradições se explicitam. Diferente é claro de momentos em que a sensação de "estar fazendo a história" era mais clara em termos subjetivos, embora, na prática, a construção do novo (podemos dizer agora, a posteriori) estivesse contaminada demais pelo velho... Talvez agora uma compreensão mais profundamente dialética a respeito das possibilidades do futuro esteja se construindo. 


\section{REFERÊNCIAS BIBLIOGRÁFICAS}

AGUIAR, A. C. Inserção e desenvolvimento docente no curso de medicina da UEL: um retrato em 2001. Pesquisação: resultados da fase exploratória. Londrina, 2001. Mimeografado.

ALMEIDA FILHO, N. A ciência da saúde. São Paulo: Hucitec, 2000.

ALMEIDA, M. J. Educação médica e saúde: possibilidades de mudança. Rio de Janeiro: Ed. UEL \& ABEM, 1999.

ALMEIDA, M. J. As mudanças na educação médica diante da transformação da profissão médica: contribuição de Londrina. Londrina, 1993. Mimeografado.

ALMEIDA, M. J.; VANUCCHI, M. O. Autoavaliação dos primeiros 12 meses: informe da direção do CCS ao $2^{\circ}$. Seminário de Autoavaliação do PROUNI-LD. Londrina, 1993. Mimeografado.

ANTUNES, C. Como transformar informações em conhecimento. Petrópolis: Vozes, 2001.

APPLE, M. Educação e Poder. Porto Alegre: Art Méd, 1989.

AROCENO, T. M. et al. Internato de Enfermagem na área de Saúde Pública: a participação das unidades básicas. Divulg. Saúde Debate, n. 15, p. 98-100, nov. 1996.

ASSOCIAÇÃO BRASILEIRA DE EDUCAÇÃO MÉDICA, II Fórum Nacional de Avaliação do Ensino Médico. In: Anais do XXXI Congresso Brasileiro de Educação Médica, 1993.

ASSOCIAÇÃO BRASILEIRA DE EDUCAÇÃO MÉDICA, III Fórum Nacional de Avaliação do Ensino Médico. In: Anais do XXXI Congresso Brasileiro de Educação Médica, 1994.

ASSOCIAÇÃO BRASILEIRA DE EDUCAÇÃO MÉDICA, IV Fórum Nacional de Avaliação do Ensino Médico. In: Anais do XXXI Congresso Brasileiro de Educação Médica, 1995.

BARBOSA, N. B.; ROCHA, N. D. Práticas inovadoras na assistência à saúde. In: ALMEIDA, M. J.; FEUERWERKER, L. C. M.; LLANOS, M. V. A educação dos 
profissionais de saúde na América Latina: teoria e prática de um movimento de mudança. São Paulo: Hucitec, 1999. v. 12.

BARROWS, H.S. A Taxonomy of problem-based learning methods. Med. Educ., Oxford, v. 20, n. 6, p. 481-486, Nov. 1986

BECKER, H. S. Métodos de pesquisa em ciências sociais. São Paulo: Hucitec, 1997.

BERBEL, N. Metodologia da problematização: fundamentos e aplicações. Londrina: Ed. UEL, 1999.

BLOOM, B. Taxonomía de los objetivos de la educación. Buenos Aires: El Ateneo, 1971.

BONILLA, V. D. et al. Causa popular e ciência popular: uma metodologia do conhecimento científico através da ação. In: BRANDÃO, C. R. Repensando a pesquisa participante. 3. ed. São Paulo: Brasiliense, 2000.

BORDENAVE, J. D.; PEREIRA, A. M. Estratégias de ensino-aprendizagem. Rio de Janeiro: Vozes, 1998.

BRAGA, J. C. S.; PAULA, S. G. Saúde e previdência: estudos de política social. São Paulo: Hucitec, 1981.

BRASIL, Decreto $n^{\circ} 80281 / 77$. Dispõe sobre a regulamentação da residência médica e criação da Comissão Nacional de Residência Médica. 1977.

BRASIL. Ministério da Saúde. Relatório Final da XI Conferência Nacional de Saúde. Brasília, 2001.

CAMPOS, F. E.; BELISARIO, S. A. O Programa de Saúde da Família e os desafios para a formação profissional e educação continuada. Interface: Comunicação, Saúde, Educação, Botucatu, v. 5, n. 9., 2001.

CAMPOS, G. W. S. Considerações sobre a arte e a ciência da mudança: revolução e reforma das pessoas. O caso da saúde. In: CECILIO, L. C. O. (Org.). Inventando a mudança na saúde. São Paulo: Hucitec, 1994.

CAMPOS, G. W. S. Equipes de referência e apoio matricial: um ensaio sobre a organização do trabalho em saúde. Ciênc. Saúde Coletiva, Rio de Janeiro, v. 4, n. 2, p. 393-403, 1999. 
CAMPOS, G. W. S. Um método para análise e co-gestão de coletivos. São Paulo: Hucitec, 2000.

CAMPOS, J. J. B. Como abrir espaços para a transformação do ensino médico no Brasil. Rev. Bras. Educ. Med., Rio de Janeiro, v. 23, n. 2/3, mai./dez. 1999.

CAMPOS, J. J. B. et al. Gestión de calidad de la enseñanza médica: el caso Londrina, Brasil. Encuentro Continental de Educación Médica. Organización Panamericana de la Salud y Facultad de Medicina de la Universidad de la República, Punta del Este, Uruguay, 1994.

CAMPOS, J. J. B.; BADUY, R. S. Apresentação no Seminário do Componente Acadêmico do Programa UNI. São Paulo, 2000. Mimeografado.

CAMPOS, J. J. B.; GORDAN, P. A. Apresentação à nova proposta curricular do curso médico do CCS/UEL. Londrina, 1997. Apostilado.

CANESQUI, A. M. Ciências Sociais e Saúde para o Ensino Médico. São Paulo: Hucitec - FAPESP, 2000.

CANGUILHEM, G. O normal e o patológico. 3. ed. Rio de Janeiro: Forense Universitária, 1990. p. 183-185.

CAOLHO, I. Seminário de Avaliação do Sistema Seriado do Curso de Medicina da UEL: a opinião dos estudantes. Caolho, publicação do Centro Acadêmico Samuel Pessoa, ago. 1996.

CARDARELLI, G. Socios, voceros o usuarios? La participación de la comunidad en el marco de los proyectos UNI. Apresentado no Encontro Internacional de Lideranças Comunitárias UNI. Brasília, 1996. Mimeografado.

CÉSAR, D. A primavera de Londrina: o despertar de uma cidade. Londrina: Midiograf, 2001.

CHAVES, M., FEUERWERKER, L.C.M., TANCREDI, F.B. Revisitando o ideário e reconstruindo a proposta. In: ALMEIDA, M. J. et al. A educação dos profissionais de saúde na América Latina: teoria e prática de um movimento de mudança. São Paulo: Hucitec, 1999a.

CINAEM. Preparando a transformação da educação médica brasileira.. Pelotas: Universidade Federal de Pelotas, 2000. 
COMISSÃO DE AVALIAÇÃO. Módulo 1: uma análise. Londrina, 1998a. Mimeografado.

COMISSÃO DE AVALIAÇÃO. Módulo 2: uma análise. Londrina, 1998b. Mimeografado.

COMISSÃO DE IMPLANTAÇÃO DO NOVO CURRÍCULO DE MEDICINA. Ata da 82a. reunião da comissão de implantação. Londrina, set. 1999. Mimeografado.

COMISSÃO DE IMPLANTAÇÃO DO NOVO CURRÍCULO DE MEDICINA. Ata da 63a reunião ordinária. Londrina, 1999b. Mimeografado.

CONSELHO DE SAÚDE DA REGIÃO SUL. Diário de lutas: a saúde como a gente quer. Londrina: Grafimix, 2000.

COSTA, H. O. G. et al. O processo de construção e de trabalho da Rede UNIDA. Divulg. Saúde Debate, Rio de Janeiro, n. 22, dez. 2000.

DELUIZ, N. Mudanças no mundo do trabalho e necessidades de qualificação dos trabalhadores de saúde: texto apresentado à Reunión de la Red Lationamericana de Técnicos em Salud OPS/OMS. Rio de Janeiro, 1997. Mimeografado.

DEMO, P. Desafios modernos da educação. Petrópolis: Vozes, 1998.

DEMO, P. Conhecimento moderno sobre ética e intervenção do conhecimento. Rio de Janeiro: Vozes, 1997.

DEPRESBITERIS, L. O Desafio da Avaliação da Aprendizagem: dos fundamentos a uma proposta inovadora. São Paulo: EPU, 1989.

DEWEY, J. A experiência da educação. São Paulo: Nacional, 1971.

DUBOS, R. The mirage of health: Nova York, Doubleday, 1961. In: SAYD, J. D. Mediar, medicar, remediar: aspectos da terapêutica na medicina ocidental. Rio de Janeiro: Ed. UERJ, 1998.

EIBENSCHUTZ, C. H. Atención a la salud y poder ciudadano: elementos clave en la articulación público/privada. In: Eibenschutz, C. H. (Org.) Política de Saúde: o público e o privado. Rio de Janeiro: Ed. Fiocruz, 1995. 
ELIAS, P. E. M. Residência médica no Brasil: a institucionalização da ambivalência. 1987. 155 f. Tese Mestrado em Medicina Preventiva - Departamento de Medicina Preventiva, Universidade de São Paulo, São Paulo.

FACULDADE DE MEDICINA DE MARÍLIA. FAMEMA 2000: programa de ensino-aprendizagem centrado no estudante, baseado em problemas e orientado à comunidade. Marília, 1997. Disponível em CD.

FACULDADE DE MEDICINA DE MARÍLIA. Manuais das unidades educacionais 2001. Marília, 2001. Apostilado.

FACULDADE DE MEDICINA DE MARÍLIA. Manual da interação comunitária $20011^{a}$. série. Marília, 2001b. Mimeografado.

FACULDADE DE MEDICINA DE MARÍLIA. Manual da interação comunitária $20012^{\text {a }}$. série. Marília, 2001c. Mimeografado.

FACULDADE DE MEDICINA DE MARÍLIA. Manual da interação comunitária $20013^{a}$. série. Marília, 2001d. Mimeografado.

FACULDADE DE MEDICINA DE MARÍLIA. Manual da interação comunitária 2001 4a. série. Marília, 2001e. Mimeografado.

FACULDADE DE MEDICINA DE MARÍLIA. Carta circular aos docentes a respeito do programa de educação permanente. Marília, 2002. Mimeografado.

FERREIRA, J. R. El análisis prospectivo de la educación médica. Educ. Med. Salud, Washington, v. 22, n. 3, p. 242-367, jul./sept. 1988.

FERREIRO, E.; TEBEROSKY, A. Psicogênese da língua escrita.. Porto Alegre: Artes Médicas, 1985.

FEUERWERKER, L. C. M. O Projeto UNI Londrina e alguns desafios no processo de mudança na medicina : notas para uma conversa. Londrina, 2000. Mimeografado.

FEUERWERKER, L. C. M. Cinco caminhos para não abrir espaços de transformação do ensino médico. Rev. Bras. Educ. Med., Rio de Janeiro, v. 23, n. 2/3, p. 21-26, 1999.

FEUERWERKER, L. C. M. Mudanças na educação médica e residência médica no Brasil. São Paulo: Hucitec, 1998. 
FEUERWERKER, L. C. M.; SENA, R. R. A construção de novos modelos acadêmicos, de atenção à saúde e de participação social. In: ALMEIDA, M. J. et al. A educação dos profissionais de saúde na América Latina: teoria e prática de um movimento de mudança. São Paulo: Hucitec, 1999a.

FEUERWERKER, L.C.M., MARSIGLIA, R.G. Estratégias para mudança na formação de RHs com base nas experiências IDA/UNI. Divulg. Saúde Debate, no. 12: 24-8. Londrina: 1996.

FLEXNER, A. Medical education in the United States and Canada: a report to the Carnegie Foundation for the Advancement of Teaching. New York: [s.n.], 1910. p. 53-55.

FÓRUM DE DEBATES SOBRE O NOVO CURRÍCULO DE MEDICINA DA UNIVERSIDADE ESTADUAL DE LONDRINA: RELATÓRIO FINAL. Londrina, 2000. Mimeografado.

FÓRUM DE DESENVOLVIMENTO CURRICULAR. Notas. Marília, 2001. Mimeografado.

FREIRE, P. Educação como prática de liberdade. Rio de Janeiro: Paz e Terra, 1975.

FREIRE, P. Pedagogia da autonomia: saberes necessários à prática educativa. São Paulo: Paz e Terra, 1998.

FUNDAP. Oportunidades de acesso à residência médica. FUNDAP, 1999.

GADOTTI, M. História das idéias pedagógicas. São Paulo: Ática, 1998.

GAJARDO, M. Pesquisa participante: propostas e reflexões metodológicas. In: BRANDÃO, C. R. Repensando a pesquisa participante. 3.ed. São Paulo: Brasiliense, 2000.

GALLO, E. Inovação, planejamento estratégico e gestão de qualidade nas escolas médicas brasileiras. Cadernos da FUNDAP, n. 19, p.131-152, 1996.

GARANHANI, M. L. et al. Superando desafios na construção de amplas reformas curriculares. In: ALMEIDA, M. J.; FEUERWERKER, L. C. M.; LLANOS, M. V. A educação dos profissionais de saúde na América Latina: teoria e prática de um movimento de mudança. São Paulo: Hucitec, 1999. t. 2.

GARCIA, J. C. La educación médica en la América Latina. OPS/OMS, Washington, n. $255,1972$. 
GERSCHMAN, S. Democracia, políticas sociais e globalização: relações em revisão. In: GERSCHMAN, S.; VIANNA, M. L. W. A miragem da pós-modernidade. Rio de Janeiro: Ed. Fiocruz, 1997.

GOODMAN GILMAN. Princípios farmacológicos da terapêutica. In: SAYD, J. D. Mediar, medicar, remediar: aspectos da terapêutica na medicina ocidental. Rio de Janeiro: Ed. UERJ, 1998.

GUIMARÃES, A.M.D.M. Extensão Universitária como reconfiguração de saberes. In: LEITE, D.B.C, MOROSINI,M. (orgs). Universidade Futurante: produção do ensino e inovação. Campinas: Papirus, 1997.

IBAÑEZ, N.; MARSIGLIA, R. Medicina e saúde: um enfoque histórico. In: CANESQUI, A. M. Ciências sociais e saúde para o ensino médico. São Paulo: Hucitec, 2000.

ISHII, E. Y.; LIBONI, M.; MANSANO, R. M. Após 30 anos renasce um novo curso de medicina. Caolho, set. 1997.

ISQUIERDO, J. A comunidade como componente essencial dos projetos UNI. In: CHAVES, M.; KISIL, M. Programa UNI: uma nova iniciativa na formação dos profissionais de saúde. Battle Creek: W. K. Kellogg Foundation, 1994.

ITO, A. M. Y. Aprendendo a aprender, conhecendo o viver. Divulg. Saúde Debate, Londrina, n. 11, p. 53-58, set. 1995.

ITO, A. M. Y. Estratégias de reforma da educação dos profissionais de saúde na UEL. Divulg. Saúde Debate, Londrina, n. 9, p. 55-58, ago. 1994.

ITO, A. M. Y. et al. Desenvolvimento de um novo modelo PROUNI Londrina (1991-1997): sistematização e reflexões teórico-metodológicas. Semina, Londrina, v. 18, n. esp., nov. $1997 \mathrm{~b}$.

ITO, A. M. Y; NUNES, E. F. P. A.; MENEZES,V. L. PEEPIN: uma experiência inovadora na educação superior. Londrina: Ed. UEL, 1997a.

KISIL, M.; CHAVES, M. Programa UNI: uma nova iniciativa na educação dos profissionais de saúde. Battle Creek: Fundação Kellogg, 1994.

KOMATSU, R. Caderno das unidades de apresentações clínicas. Marília, 2001. Mimeografado. 
KOMATSU, R. Desenvolvimento curricular: transformando docentes e discentes em busca de um novo processo de formação. Preparando a transformação da Educação Médica Brasileira, Projeto CINAEM, III fase. 2000. p113-128. São Paulo.

KOMATSU, R. et al. Guia do processo de ensino-aprendizagem: aprendendo a aprender. Marília, 1997a. Apostilado.

KOMATSU, R. et al. Manual FAMEMA 1997. Marília, 1997b. Apostilado.

KOMATSU, R. et al. Trilhando novos caminhos: uma experiência pioneira. In: ALMEIDA, M. J; FEUERWERKER, L. C. M.; LLANOS, M. V. A educação dos profissionais de saúde na América Latina: teoria e prática de um movimento de mudanças. São Paulo: Hucitec, 1999. t. 2.

KOMATSU, R.; ZANOLLI, M. B; LIMA,V. V. Aprendizagem baseada em problemas. In: MARCONDES, E.; GONÇALVES, E. L. Educação médica. São Paulo: Sarvier, 1998.

LIMA, V. V et al. Caderno de Avaliação. Marília: FAMEMA, 1999.

LIMA, V. V. Educação médica: a dimensão social no currículo do curso médico da Faculdade de Medicina de Marília em 1998 e 1999. 2000. 296p. Tese (Doutorado em Saúde Pública) - Faculdade de Saúde Pública, Universidade de São Paulo, São Paulo.

LIMA, V. V.; SEIFFERT, O. M. L. B. A avaliação no Projeto CINAEM: preparando a transformação da educação médica brasileira, III fase. 2000. p139-146. São Paulo .

LIMA, V. V.; KOMATSU, R.; PADILHA, R. Q. UNI-MARÍLIA: capacitação de recursos humanos e desenvolvimento de lideranças. Divulg. Saúde Debate, Londrina, v. 12, p. 90-96, jul. 1996.

LÜDKE, M.; SALLES, M. Q. P. Avaliação da aprendizagem na educação superior. In: LEITE, D. B. C; MOROSNINI, M. (Org). Universidade Futurante. Campinas: Papirus, 1997.

MACHADO, M. H. (Coord.). Os médicos no Brasil: um retrato da realidade. Rio de Janeiro: Ed. Fiocruz, 1997.

MACHADO, M. H.; BELISARIO, S. A. Os médicos e o mercado de trabalho. In: CANESQUI, A. M. (Org.) Ciências sociais no ensino médico. São Paulo: Hucitec, 2000. 
MAGALHÃES, A. M. D. M. Extensão universitária como reconfiguração de saberes. In: LEITE, D. B. C.; MOROSNI, M. (Org.). Universidade futurante. Campinas: Papirus, 1997.

MARSIGLIA, R.G. Relação ansino/serviços: dez anos de integração docenteassistencial (IDA) no Brasil. São Paulo: Hucitec, 1995.

MATTOS, R.A. Os sentidos da integralidade: algumas reflexões acerca de valores que merecem ser defendidos. In: PINHEIRO, R., MATTOS, R.A. (Org). Os sentidos da integralidade na atenção e no cuidado à saúde. Rio de Janeiro: UERJ. IMS: ABRASCO, 2001.

MATUS, C. O método PS. In: HUERTAS, F. Entrevista com Carlos Matus. São Paulo: Ed. Fundap, 1996.

MCNEIL, J. D. Currículo acadêmico. In: DESPRESBITERIS, L. O desafio da avaliação da aprendizagem: dos fundamentos a uma proposta inovadora. São Paulo: Ed.Pedagógica Universitária , 1989a.

MCNEIL, J. D. Currículo humanístico. In: DESPRESBITERIS, L. O desafio da avaliação da aprendizagem: dos fundamentos a uma proposta inovadora. São Paulo: Ed. Pedagógica Universitária, 1989b.

MCNEIL, J. D. Currículo reconstrução social. In: DESPRESBITERIS, L. O desafio da avaliação da aprendizagem: dos fundamentos a uma proposta inovadora. São Paulo: Ed. Pedagógica Universitária, 1989c.

MCNEIL, J. D. Finalidades do currículo. In: DESPRESBITERIS, L. O desafio da avaliação da aprendizagem: dos fundamentos a uma proposta inovadora. São Paulo: Ed. Pedagógica Universitária, 1989d.

MCNEIL, J. D. Tecnologia e currículo. In: DESPRESBITERIS, L. O desafio da avaliação da aprendizagem: dos fundamentos a uma proposta inovadora. São Paulo: Ed. Pedagógica Universitária, 1989e.

MÉDICI, A. C. Economia e financiamento do setor saúde no Brasil: balanço e perspectivas do processo de descentralização. São Paulo: AdSaúde, 1994. (Série Temática, p.71-113 e 179-192).

MENDES, E. V. Uma agenda para a saúde. São Paulo: Hucitec, 1996.

MERHY, E. E. Em busca da qualidade dos serviços de saúde: os serviços de porta aberta para a saúde e o modelo técnico-assistencial em defesa da vida. In: 
CECILIO, L. C. O. et al. Inventando a mudança na saúde. São Paulo: Hucitec, 1994.

MERHY, E. E. Em busca do tempo perdido: uma micro-política do trabalho vivo em saúde. In: MERHY, E.; ONOCKO, R. Agir em saúde: um desafio para o público. São Paulo: Hucitec, 1997.

MERHY, E. E.; MAGALHÃES JUNIOR, H. Regulação pública na saúde suplementar: a quem interessa? Rio de Janeiro, 2001. Material mimeografado.

MINAYO, M. C. S. O desafio do conhecimento. São Paulo: Hucitec, 1992.

MURAGACHI, E. M. O. 1o. Seminário de Avaliação do Curso de Medicina da UEL, 1996. Caolho, publicação do Centro Acadêmico Samuel Pessoa, set. 1996.

OFICINA PIN/Interação Comunitária. Relatório de oficina conjunta entre os cursos de medicina e enfermagem da UEL e da FAMEMA. Londrina, 1998. Mimeografado.

PADILHA,R.Q. Os hospitais de ensino e a previdência social: estudo de caso. São Paulo. 1996. Tese ( Mestrado em Saúde Pública) - Faculdade de Saúde da Pública, Universidade de São Paulo.

PAIM, J. S. Recursos humanos em saúde no Brasil: problemas crônicos e desafios agudos. São Paulo: AdSaúde, 1994. (Série Temática 1, Faculdade de Saúde Pública/USP).

PELLEGRINI, D. Terra vermelha. São Paulo: Moderna, 1998.

PÉREZ GÓMEZ A.I.P. Compreender o ensino na escola: modelos metodológicos de investigação educativa. In: SACRISTÁN, J.G., PÉREZ GÓMEZ A.I.P. Compreender e transformar o ensino. $4^{\mathrm{a}}$.ed. Porto Alegre: Artmed, 1998.

PIAGET, J. Para onde vai a educação? 10. ed. Rio de Janeiro: José Olympio, 1988.

PICCINI, R. X. et al. Projeto de avaliação das escolas médicas do Brasil: relatório parcial - dados preliminares. Pelotas: [s.n.], 1996.

PINHEIRO, R.; MATTOS, R. A. (Org.). Os sentidos da integralidade na atenção e no cuidado à saúde. Rio de Janeiro: IMS-UERJ-ABRASCO, 2001.

PONTES, R. H. P. Reforma curricular no ensino médico: estudo de caso de uma escola de medicina. 2001. 160 p. Tese (Doutorado em Saúde Pública) - Faculdade 
de Saúde Pública, Universidade de São Paulo, São Paulo.

PROGRAMA UNI. Relatório da oficina de avaliação. São Paulo, 1998. Mimeografado.

PROGRAMA UNI. Seminários de sistematização: desenvolvimento do UNI na academia. Miami, 1997a. Mimeografado.

PROGRAMA UNI. Seminários de sistematização: desenvolvimento do UNI nas comunidades. Miami, 1997b. Mimeografado.

PROGRAMA UNI. Seminários de sistematização: desenvolvimento do UNI nos serviços de saúde. Miami, 1997c. Mimeografado.

PROGRAMA UNI. Seminários de sistematização: parceria e mudança institucional. São Paulo, 1997d.

PROJETO UNI BAHIA. Relatório de avaliação do terceiro ano da segunda fase. Salvador, 2001. Mimeografado.

PROJETO UNI MARILIA. Relatório de autoavaliação do período de agosto de 1999 a junho de 2001. Marilia, 2001. Mimeografado.

PROJETO UNI MARILIA. Relatório de autoavaliação do período de julho de 1994 a junho de 1995. Marilia, 1995. Mimeografado.

PROJETO UNI MARILIA. Relatório de autoavaliação do período de julho de 1995 a junho de 1996. Marilia, 1996. Mimeografado.

PROJETO UNI MARILIA. Relatório de autoavaliação do período de julho de 1996 a abril de 1998. Marilia, 1998. Mimeografado.

PROJETO UNI MARILIA. Relatório de autoavaliação do período de maio de 1998 a julho de 1999. Marilia, 1999. Mimeografado.

PROJETO UNI MARILIA. Relatório de autoavaliação do período de novembro de 1992 a junho de 1994. Marilia, 1994. Mimeografado.

PROUNI LONDRINA. PROUNI LONDRINA em ação. Londrina, 1993. Apostilado.

PROUNI LONDRINA. PROUNI LONDRINA em ação II: Processos e resultados. Relatório Técnico de avaliação do $1^{\circ}$. ano (outubro de 92 a junho de 94 ). Londrina, 
1994. Mimeografado.

PROUNI LONDRINA. PROUNI LONDRINA em ação III: resultados. Relatório técnico de avaliação do $2^{\circ}$. ano (junho de 94 a junho de 1995). Londrina, 1995. Apostilado.

PROUNI LONDRINA. Relatório de autoavaliação do período de maio de 1998 a agosto de 1999. Londrina, 1999. Mimeografado.

PROUNI LONDRINA. Relatório de autoavaliação do período de outubro de 1999 a setembro de 2000. Londrina, 2000. Mimeografado.

PROUNI LONDRINA. Uma nova iniciativa na educação dos profissionais de saúde: união com a comunidade: projeto apresentado à Fundação Kellogg para uma segunda fase de financiamento. Londrina, jun. 1996. Apostilado.

RAMSDALE, H. (Org.). VADEMECUM: unit one handbook. \{S.1.]: McMaster University, 1996.

RANGEL, M. L.; VILASBOAS, A. L. Rede UNIIDA: breve histórico, concepção, organização e estratégias de ação. Div. Saúde Deb., Londrina, n. 12, 1996.

REDE UNIDA. A construção de modelos inovadores de ensino-aprendizagem: as lições aprendidas pela Rede UNIDA. Div. Saúde Deb., n. 22, Rio de Janeiro, 2000b.

REDE UNIDA. Agenda estratégica: para movimentar mudanças na formação dos profissionais de saúde no Brasil. Boletim da REDE UNIDA, Salvador, v. 4, n. 3, 2000c.

REDE UNIDA. Boletim da REDE UNIDA. Londrina, v. 4, n. 36, 2001.

REDE UNIDA. Contribuição para as novas diretrizes curriculares dos cursos de graduação da área da saúde. Olho Mágico, Londrina, v. 4, n. 16, 1998.

REDE UNIDA. Diversificação de cenários de ensino e trabalho sobre necessidades/problemas da comunidade. Div. Saúde Deb., Rio de Janeiro, n. 22. 2000a.

REDE UNIDA. O movimento de mudança da formação de profissionais de saúde no Brasil. Div. Saúde Deb., Rio de Janeiro, n. 22, 2000c.

REDE UNIDA. Relatório da oficina de trabalho sobre a atuação dos membros da Rede UNIDA nos pólos de capacitação de Saúde da Família. Londrina, 2001. 
Mimeografado.

REGO, S. T. A. Saindo da adolescência com a vida (dos outros) nas mãos: um estudo sobre a formação ética dos estudantes de medicina. 2001. 182p. Tese (Doutorado em Saúde Coletiva) - Instituto de Medicina Social, Universidade Estadual do Rio de Janeiro, Rio de Janeiro.

ROCHA, J. $S$ Y. A crise da terminalidade da educação médica no Brasil. Rev. Bras. Educ. Med., Rio de Janeiro, v. 7, n. 1, p. 36-41, 1983.

RODRIGUEZ, M. I. Las innovaciones educativas en la formación de personal de salud en México dentro del contexto de las transformaciones ocurridas em América Latina. Educ. Med. Salud, Washington, v .29, n. 1, 1995.

ROGERS, C. Liberdade para aprender. Belo Horizonte: Interlivros, 1987.

RORTY, R. Pragmatismo: a filosofia da criação e da mudança. Belo Horizonte: Ed. UFMG, 2000.

ROSA, A. R. O componente acadêmico dos Projetos UNI. In: Programa UNI: uma nova iniciativa na educação dos profissionais de saúde. Battle Creek: Fundação Kellogg, 1994.

ROVERE, M. Planificación estratégica de recursos humanos en salud. Série Desarrollo de Recursos Humanos, no. 96. OPS. Washington D.C., 1996.

ROVERE. M. Seminário de Planejamento Estratégico da Rede UNIDA. Mimeo. Salvador, 1998.

SACRISTÁN,J.G. O currículo: uma reflexão sobre a prática. Porto Alegre: ArtMed, 2000.

SANTOS, B. S. A crítica da razão indolente: contra o desperdício da experiência. São Paulo: Cortez, 2000.

SANTOS, B. S. Um discurso sobre as ciências. Porto: Afrontamento, 1996.

SANTOS, N. R. A prática social através dos Conselhos de Saúde. Divulg. Saúde Debate, Rio de Janeiro, n. 22, 2000.

SANTOS, R. C. Construindo outro dia-a-dia para os estudantes de medicina nas escolas médicas do Brasil. Sustentação, v. 3, n. 6, 2001. 
SAUL, A. M. Avaliação emancipatória: desafio à teoria e à prática de reformulação de currículo. São Paulo: Cortez, 2000.

SAYD, J. D. Mediar, medicar, remediar: aspectos da terapêutica na medicina ocidental. Rio de Janeiro: Ed. UERJ, 1998.

SCHRAIBER, L. B. Educação médica e capitalismo. São Paulo: Hucitec, 1989.

SCHRAIBER, L. B. A profissão de ser médico. In: CANESQUI, A. M. Ciências sociais e saúde para o ensino médico. São Paulo: FAPESP/Hucitec, 2000.

SCHRAIBER, L. B. O médico e seu trabalho. São Paulo: Hucitec, 1993.

SEADE. Perfil dos municípios do estado de São Paulo. Disponível em: <http:// www.seade.org.br>. Acesso em : 09 fev.2002.

SEMINA. Revista Cultural e Científica da Universidade Estadual de Londrina, Londrina, v. 17, nov. 1996.

SEMINA. Revista Cultural e Científica da Universidade Estadual de Londrina, Londrina, v. 18, 1997.

SEMINA. Revista Cultural e Científica da Universidade Estadual de Londrina, Londrina, v. 19, 1998.

SIEBENEICHLER, F. B. Jürgen Habermas: razão comunicativa e emancipação. Rio de Janeiro: Tempo Brasileiro, 1989.

SILVA FILHO, C. R. Modelo Acadêmico. Divulg. Saúde Debate, Rio de Janeiro, n. 9, 1994.

SILVA, R. F. Prática educativa transformadora: a trajetória da unidade educacional de interação comunitária. 2000. 143p. Tese (Doutorado em Saúde Pública)Faculdade de Saúde Pública, Universidade de São Paulo, São Paulo.

SILVA, R. M. R. S. PEEPIN: uma prática de ensino inovadora no CCS. Olho Mágico, Londrina, v. 3, n. 3, set. 1996.

SNELLEN-BALEDONG, H.; GOEIJ, T. Relatório de avaliação após visita e oficina de trabalho. Londrina, 1999. Mimeografado.

SOARES, A. D.; GIL, C. R. R.; ITO, A. M. Y. Projeto UNI Londrina: processos e resultados. Divulg. Saúde Debate, Rio de Janeiro, n. 12, jul. 1996. 
SOUZA, E. G. Residência médica no Brasil. Rev. Bras. Educ. Med., v. 9, n. 2, p. 112$114,1985$.

TANCREDI, F.B, NIREMBERG,O.,PERRONE, N. Avaliação como ferramenta estratégica e como processo. In: ALMEIDA, $M$. J. et al. A educação dos profissionais de saúde na América Latina: teoria e prática de um movimento de mudança. São Paulo: Hucitec, 1999a.

TESTA, M. Pensamento estratégico e lógica de programação: o caso da saúde. São Paulo: Hucitec, 1995.

TESTA, M. Pensar em Saúde. Porto Alegre: Artes Médicas, 1992.

THOMSON, J. C.; LIMA, G. Z. Manual do aluno. Londrina, 1998. Apostilado.

TSUJI, H.; ZANOLLI, M. Manual do internato 2002. Marília, 2002. Apostilado.

TURINI, B. et al. Fortalecendo as organizações comunitárias e desenvolvendo a cidadania. In: ALMEIDA, M. J.; FEUERWERKER, L. C. M.; LLANOS, M. V. A educação dos profissionais de saúde na América Latina: teoria e prática de um movimento de mudança. São Paulo: Hucitec, 1999.

TURINI, B. et al. Práticas interdisciplinares de interação ensino-serviçocomunidade, como motivação para o estudo do Sistema de Atenção à Saúde de Londrina. In: CONGRESSO BRASILEIRO DE EDUCAÇÃO MÉDICA, 35., 1999, Riode Janeiro: Anais, p. 138.

TURINI, B. Interação com os serviços e com a comunidade durante a formação médica: o que pensam os professores. 2000. Dissertação (Mestrado em Saúde Coletiva) - Centro de Ciências da Saúde, Universidade Estadual de Londrina, Londrina.

UNIVERSIDADE ESTADUAL DE LONDRINA. Centro de Ciências da Saúde. Uma inovação no ensino das profissões da saúde: o PEEPIN. Londrina, 1992. Mimeografado.

UNIVERSIDADE ESTADUAL DE LONDRINA. Centro de Ciências da Saúde. Boletim especial do colegiado de medicina. Londrina, dez. 1997a.

UNIVERSIDADE ESTADUAL DE LONDRINA. Centro de Ciências da Saúde. Novo currículo do curso de medicina. Londrina, 1997b. Apostilado. 
UNIVERSIDADE ESTADUAL DE LONDRINA. Centro de Ciências da Saúde. O novo currículo de medicina da UEL: uma apresentação. Londrina, 1998. Mimeografado.

UNIVERSIDADE ESTADUAL DE LONDRINA. Centro de Ciências da Saúde. Manual de Habilidades. Londrina, 1998a. Apostilado.

UNIVERSIDADE ESTADUAL DE LONDRINA. Centro de Ciências da Saúde. Introdução à medicina: módulo 1. Londrina, 1998b. Material apostilado.

UNIVERSIDADE ESTADUAL DE LONDRINA. Centro de Ciências da Saúde. Concepção e formação do ser humano: módulo 2. Londrina, 1998c. Apostilado.

UNIVERSIDADE ESTADUAL DE LONDRINA. Centro de Ciências da Saúde. Metabolismo: módulo 3. Londrina, 1998d. Apostilado.

UNIVERSIDADE ESTADUAL DE LONDRINA. Centro de Ciências da Saúde. Abrangência das ações de saúde: módulo 7. Londrina, 1998e. Apostilado.

UNIVERSIDADE ESTADUAL DE LONDRINA. Centro de Ciências da Saúde. Nascimento, crescimento e desenvolvimento: módulo 9. Londrina, 1999a. Apostilado.

UNIVERSIDADE ESTADUAL DE LONDRINA. Centro de Ciências da Saúde. Proliferação Celular: módulo 10. Londrina, 1999b. Apostilado.

UNIVERSIDADE ESTADUAL DE LONDRINA. Centro de Ciências da Saúde. Processo de Envelhecimento: módulo 13. Londrina, 1999c. Apostilado.

UNIVERSIDADE ESTADUAL DE LONDRINA. Centro de Ciências da Saúde. Práticas interdisciplinares de interação ensino, serviços e comunidade: módulo 16. Londrina, 1999d. Apostilado.

UNIVERSIDADE ESTADUAL DE LONDRINA. Centro de Ciências da Saúde. $2^{\circ}$ Workshop de Habilidades no currículo PBL da UEL. Londrina, jul. 1999e. Mimeografado.

UNIVERSIDADE ESTADUAL DE LONDRINA. Centro de Ciências da Saúde. Relatório da 3a. Oficina de Planejamento do Colegiado de Medicina. Londrina, 1999f. Mimeografado. 
UNIVERSIDADE ESTADUAL DE LONDRINA. Centro de Ciências da Saúde. Planilha para Avaliação das Condições de Oferta. Ministério da Educação. Londrina, 2001. Mimeografado.

UNIVERSIDADE ESTADUAL DE LONDRINA. Centro de Ciências da Saúde. Relatório de avaliação do projeto de apoio à reforma curricular do curso de medicina. Londrina, 2002a. Mimeografado.

UNIVERSIDADE ESTADUAL DE LONDRINA. Centro de Ciências da Saúde. GRUPO-tarefa para elaboração da proposta de carta-compromisso da UEL na adesão ao Programa de Incentivos às Mudanças nos Cursos de Medicina. PROMED. Londrina, 2002b. Mimeografado.

UNIVERSIDADE ESTADUAL DE LONDRINA. Centro de Ciências da Saúde. Relatório do processo de reformulação dos estágios de integração ensino-serviçocomunidade. Londrina, 2002c. Mimeografado.

VANUCHI, M. T. O. et al. Internato do curso de enfermagem da UEL: relato de uma experiência. Rev. Div. Saúde Deb., Rio de Janeiro, n. 15, 1996.

VENTURELLI, J. Proposta de formação docente: alguns aspectos chave para um programa de capacitação docente no curso de medicina da Universidade Estadual de Londrina. Londrina, 1999. Mimeografado.

VIEIRA, M. P. A.; PEIXOTO, M. R. C.; KHOY, Y. M. A. A pesquisa em história. São Paulo: Ática, 1991.

WORLD HEALTH ORGANIZATION. A network of community-oriented educational institutions for health sciences: report of the inaugural meeting held in Kingston, Jamaica, from 4 to 8 June 1979. In: ALMEIDA, M. J. Educação médica e saúde: possibilidades de mudança. Rio de Janeiro: Ed. UEL \& ABEM, 1999.

WORLD HEALTH ORGANIZATION. Changing medical education and practice: an agenda for action. Genebra, 1991.

YOUNG, M. F. D. Curriculum changes. In: Moreira, A. F. Escola, currículo e a construção do conhecimento: palestra proferida na $6^{\mathrm{a}}$. Conferência Brasileira de Educação. 1991. 